\title{
REPERTORIUL PEISAJULUI FUNERAR DIN ZONA CONFLUENȚEI SIRETULUI CU DUNĂREA - STUDIU PRELIMINAR
}

In honorem Luciae Marinescu octogenariae

OVIDIU ŢEnTEA, AleXANDRu RAȚiU

\section{THE FUNERARY LANDSCAPE IN THE AREA OF CONFLUENCE OF SIRET AND DANUBE RIVERS. PRELIMINARY STUDY}

This study represents a summary of the funerary features identified in the confluence area of Siret and Danube rivers. The tumuli in question, representing the main subject of our presentation, were mapped on a relatively large area, both within the „Galati vallum” and its outer surroundings. Our initial research theme aimed the Roman necropolis from Barboși, which was a starting point for a wider analysis concerning the funerary landscape in the site's vicinity.

Our first contact with this area took place during the preventive archaeological excavation carried out in the eastern part of the Barboși necropolis, situated on Dunărea neighborhood, in the city of Galați. During 2008-2009 we undertook non-invasive field surveys and aerial photographs in the area, in the framework of the STRATEG research project. Upon analyzing this documentation and after corroborating the entire relevant information, we started to develop different scenarios for the complex distribution of the funerary features identified in the archaeological landscape of the named area. The aerial photographical campaign was doubled by a field walking campaign to identify and confirm the information. In addition, new features were identified, mainly through the discovery of ceramic material. The field walking campaigns continued during the years 2010 and 2012.

This article aims to provide first a status of research to the topic; the final conclusions will follow after the completion of the analysis and mapping of the findings. Our discussion is based on an ample repertoire with correspondence to the maps illustrating this paper.

Keywords: necropolis, funerary landscape, tumuli, roman period, Moesia Inferior (Lower Moesia) Cuvinte cheie: necropolă, peisaj funerar, tumuli, epocă romană, Moesia Inferior

\section{INTRODUCERE}

Acest studiu reprezintă o prezentare sintetică a complexelor funerare identificate în arealul confluenței râului Siret cu Dunărea. Tumulii la care facem referire, căci în principal despre acest tip de complexe funerare este vorba, au fost cartaţi pe un areal relativ amplu, atât în interiorul Valului Galaţiului, cât și în zonele adiacente acestuia. Tema noastră de studiu a pornit de la analiza necropolei romane de la Barboşi ${ }^{1}$, care a constituit un punct de plecare pentru o cercetare mai amplă a peisajului funerar din zona de referință. Articolul de față își propune să ofere - într-o primă etapă - un stadiu al cercetărilor, concluziile finale urmând a putea fi formulate după finalizarea analizei acestor descoperiri și cartări. Discuția noastră se bazează pe un amplu repertoriu cu corespondență în hărțile care ilustrează articolul de față.

\footnotetext{
${ }^{1}$ Pârvan 1913, 14-27; Sanie 1981, 81-84; Dragomir 1981, 73-114; Dragomir 1991, 237-245; Dragomir 1996, 525-534; Oţa 2013, 280-281; Țentea, Cleşiu 2006; Țentea 2007; Țentea, Oltean 2009; Croitoru 2013.
} 
Primul contact direct cu acest areal a fost realizat prin săpăturile arheologice de salvare derulate în zona estică a necropolei de la Barboși, situată în cartierul Dunărea, al orașului Galați ${ }^{2}$. În anii următori (2008-2009), în cadrul proiectului de cercetare STRATEG ${ }^{3}$, au fost efectuate cercetări non-invazive de teren și fotografii aeriene. În urma analizei acestei documentaţii și a coroborării informațiilor am început să dezvoltăm un scenariu pentru a înțelege complexitatea distribuției complexelor identificate în cadrul peisajul arheologic din această zonă. În cursul verii anului 2008 am realizat o campanie complexă de investigare a arealului respectiv prin efectuarea unui set de fotografii aeriene oblice ${ }^{4}$, dublate de verificarea prin periegeze a elementelor semnalate. De asemenea, au fost identificate elemente noi prin semnalarea de material arheologic. Campaniile de verificare pe teren au fost reluate în cursul anilor 2010 și $2012^{5}$.

În vederea conturării unei imagini de ansamblu asupra distribuirii complexelor funerare din necropola de la Barboşi am coroborat cartările cercetărilor arheologice proprii cu cele obținute pe baza fotografiilor aeriene efectuate în timpul celui de-al Doilea Război Mondial ${ }^{6}$.

Astfel, ne-am propus să extindem cercetarea noastră la nivelul tuturor descoperirilor cu caracter funerar din spațiul delimitat de „Valul lui Traian” - Tulucești, precum și din zona conexă acestuia. Astfel, am încercat să delimităm aliniamentul necropolei/necropolelor care au existat aici în perioada romană. Demersul a fost evident îngreunat de faptul că în arealul respectiv există numeroși tumuli care aparțin unor perioade istorice diferite. O imagine de ansamblu ne-a fost oferită de sinteza rezultată în urma unor investigații îndelungate efectuate de-a lungul a numeroși ani de către Mihalache Brudiu'. Lucrarea în cauză, bazată pe un articol preliminar publicat anterior $^{8}$, s-a dorit un repertoriu exhaustiv al tumulilor din sudul Moldovei. Informațiile sunt destul de inegale, după cum se vede și din parte a acestora preluată de noi. Unele repere pe care autorul menționat le-a folosit nu mai pot fi utilizate astăzi pentru simplu motiv că acestea au dispărut. Cele mai numeroase probleme de localizare decurg atât din cauza amintită cât și din descrierea și reprezentarea acestor complexe unul față altul.

Suportul cartografic a fost asigurat de platforma http://geo-spatial.org, iar integrarea datelor a fost realizată cu utilizarea Open Source GIS with QGIS 2.09. Ca material suport am folosit Planuri Directoare de Tragere ${ }^{10}$, Hărțile austriece (1910) reproiectate în Stereo70 ${ }^{11}$ și - în unele situații - Hărțile sovietice 1: 100000 reproiectate în Stereo $70^{12}$.

Aceste hărți înregistrează în detaliu toate curbele de nivel și mai ales diferențele de nivel relevante, movilele, evident în scopuri tactice militare. Astfel, mare parte dintre tumulii existenți / vizibili în acea perioadă sunt figurați pe aceste hărți, o parte dintre aceștia având indicat chiar și toponimul. Utilitatea acestui procedeu a fost validată în momentul integrării datelor înregistrate de noi pe teren. În câteva situații am putut identifica chiar toponimele anumitor tumuli măsurați de noi. De asemenea, prin acest procedeu am putut restitui informații despre complexe care astăzi sunt distruse (în special pentru cele din incinta combinatului siderurgic SIDEX / ISPA). La acestea am adăugat parțial date recuperate de Ioana Oltean după clișee din Al Doilea Război Mondial ${ }^{13}$.

\footnotetext{
${ }^{2}$ Țentea, Cleșiu 2006, 39-88.

3 STRATEG. Strategii defensive şi politici transfrontaliere. Integrarea spaţiului Dunării de Jos în civilizaţia romană. Pr. 4 Parteneriate, Contract CNMP 91-010, 2007-2010 - www.strateg.org.ro

4 Colectarea acestor date a fost efectuată de Ioana A. Oltean (University of Exeter) și H. S. Hanson (University of Glasgow).

5 În cursul anului 2010 am efectuat o serie de verificări pe teren ale unor informații colectate.

6 Ţentea, Oltean 2009, pl. 3, 4.

7 Brudiu 2003.

8 Brudiu 1991

9 Mulțumim pe această cale colegilor Mihai Florea și Vlad Rumega-Irimuș pentru ajutorul acordat.

${ }^{10} \mathrm{http}$ ://www.geo-spatial.org/download/planurile-directoare-de-tragere

${ }^{11} \mathrm{http} / / / \mathrm{www}$. geo-spatial.org/download/harile-austriece-1910-reproiectate-in-stereo70

12 http://www.geo-spatial.org/download/hartile-sovietice-1-100-000-reproiectate-in-stereo70

13 Tentea, Oltean 2009; Oltean 2013.
} 
Materialul prelevat de la suprafaţa solului în cursul perieghezelor a fost înregistrat folosind aparate GPS mobile, în punctele respective fiind efectuate fotografii de detaliu. Cea mai mare parte a acestor materiale a constat din fragmente de ceramică. Dintre cele încadrabile tipologic menționăm fragmente de amfore romane timpurii, precum și fragmente de vase ceramice romane de masă (PI. XXI-XXII).

După cum aminteam, demersurile noastre au început prin investigațiile din așa-numita necropolă din cartierul gălăţean „Dunărea”, considerată a fi fost „,eea mai mare necropolă romană din Moldova" ${ }^{\prime 14}$. Aceasta a reprezentat de fapt o parte din marea necropolă tumulară de la Barboși, situată de-a lungul drumului roman ${ }^{15}$. Zona a fost puternic distrusă în etape succesive de diverse intervenții antropice moderne și contemporane, iar valorificarea ştiinţifică a datelor arheologice a fost realizată într-o formă destul de lacunară.

$\mathrm{Cu}$ toate acestea, interpretările istorice au fost extrem de generoase, arealul respectiv fiind considerat a fi fost o zonă antreprenorială în care erau amplasate depozite de amfore (PI. II/1), în proximitatea acestora fiind situată necropola romană ${ }^{16}$. Complexele funerare cartate, decopertate mecanic în cea mai mare parte a lor, au fost publicate pe un plan din care se poate observa doar o distribuţie aproximativă a acestora în cadrul necropolei ${ }^{17}$. În cursul cercetărilor noastre am identificat şapte complexe funerare aflate într-o stare de conservare precară ${ }^{18}$. Cercetări ulterioare au fost efectuate în cursul unei campanii din anul 2011, care au condus la descoperirea altor câteva complexe funerare ${ }^{19}$.

Interpretarea noastră, formulată cu ocazia valorificării cercetărilor arheologice recente realizate în această zonă, pleda pentru abordarea tuturor descoperirilor arheologice din Barboşi şi din punctul „Cartier Dunărea” ca făcând parte din aceeaşi sit. Distanţa dintre tumulii din necropola de la Barboși ${ }^{20}$ şi cei cartaţi în „Cartierul Dunărea" 21 ar fi de aproximativ 700 metri, porţiunea în care tumulii sau alte complexe funerare nu au fost cartate fiind tocmai zona cea mai joasă în care au fost realizate numeroase amenajări în perioada modernă. Raportarea la dimensiunea și distribuția spațială a necropolelor similare din arealul învecinat (Noviodunum, Carsium sau Histria) pleda, în opinia noastră, pentru luarea în calcul a unei singure necropole, desfăşurată de-a lungul drumului, care traversa vadul Dunării, trecea la Nord de castrul de la Barboşi, urmând cursul Siretului înspre Barbaricum $^{22}$.

O importantă oportunitate pentru conturarea unei viziuni de ansamblu asupra complexului de clădiri şi infrastructuri, respectiv asupra necropolei de la Barboşi, a fost posibilitatea de a corobora cartările cercetărilor arheologice proprii cu cele realizate pe baza fotografiilor aeriene efectuate în timpul celui de-al Doilea Război Mondial de către aviaţia aliată, demers efectuat după cum am amintit - împreună cu Ioana Oltean ${ }^{23}$. Rezultatele interpretărilor fotografiilor aeriene semnalează existenţa unui număr de cel puțin două fortificaţii cu dimensiuni asemănătoare cu cea din cartierul Dunărea, amplasate în interiorul Valului lui Traian - Tuluceşti, dar distruse de extinderea oraşului în a doua jumătate a secolului trecut, precum şi a unui număr destul de mare de posibile turnuri de observaţie. De asemenea, extinderea necropolei spre Nord este considerabilă (PI. II). Trebuie să luăm în calcul în acest caz şi faptul că nu toţi tumulii care figurează pe acest plan aparţin necropolei romane ${ }^{24}$.

După cum arătam mai sus, dimensiunile necropolei romane de la Barboşi vor fi fost apreciabile, de vreme ce atât arealul cercetat în zona nordică a castrului de la Barboşi, cât şi

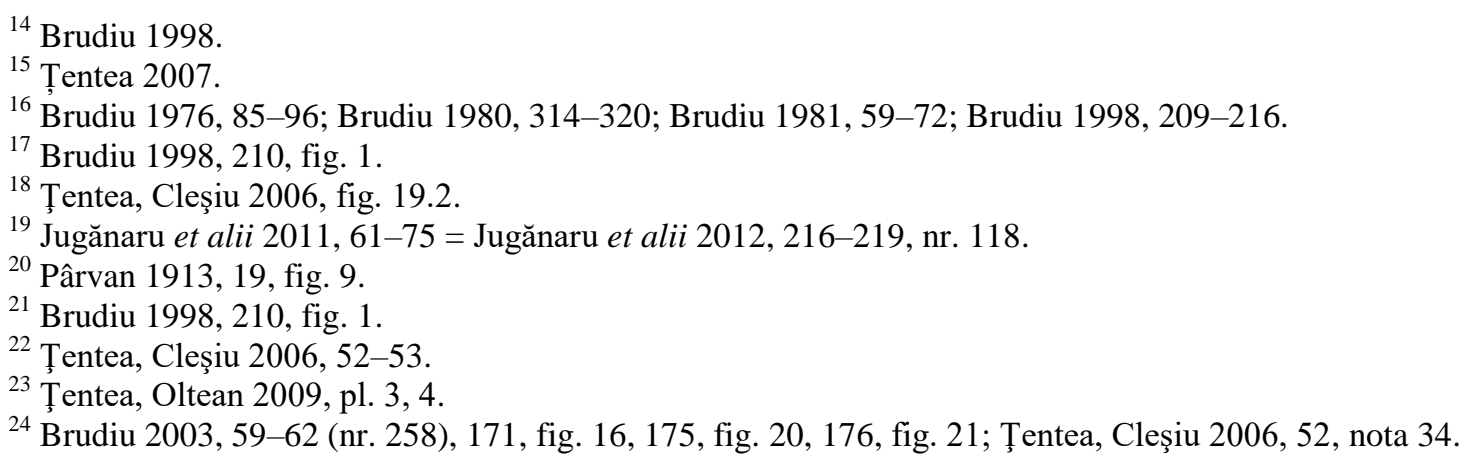


mormintele cartate în vecinătatea oraşului Galaţi au aparţinut aceleiaşi necropole. Aria de răspândire a tumulilor cartați în zonă este semnificativă, aceștia având orientări diferite față de orientarea aproximativ E-V pe care o avea drumul roman. Trebuie amintit aici faptul că o mare parte dintre tumuli aparțin unor epoci diferite ${ }^{25}$.

În încercarea definirii întinderii necropolei romane de la Barboși am luat în calcul distribuția spațială a tuturor descoperirilor funerare amplasate în interiorul „Valului lui Traian” de la Galați, precum și a celor amplasate în proximitatea nordică și vestică a acestuia. Prin acest demers ne-am propus să identificăm rațiunile cărora li se datorează distribuția spațială a acestor tumuli.

Pornind de la aserțiunea lui Vasile Pârvan privind existența unui drum roman care străbătea această zonă pe direcția E-V (PI. I/1, II/1), ar fi fost de presupus că distribuirea tumulilor aparținând epocii romane s-a concentrat de-a lungul acestuia. După cum vom vedea situația este mult mai complexă. Numeroasele descoperiri funerare, în marea lor majoritate tumuli, au făcut parte din aliniamente cu o întindere considerabilă, situate pe poziții dominante, orientate aproximativ $\mathrm{N}-\mathrm{S}$.

Vom aminti în cele ce urmează principalele descoperiri aparţinând epocii romane. Una dintre cele mai importante descoperiri este sarcofagul de marmură, inscripționat cu numele Alphenus Modestus, descoperit în vecinătatea promontoriului Tirighina ${ }^{26}$. La o distanță apreciabilă spre Est, în cartierul Dunărea, a fost descoperit un cavou databil în secolul al IV-lea p. Chr. ${ }^{27}$

În necropola de la Barboşi au fost cercetați de-a lungul timpului mai mulți tumuli ${ }^{28}$. Mai recent a fost cercetat un alt tumul situat la Nord de așa-numitul castellum și de drumul național (nr. 555) ${ }^{29}$, făcând parte din grupul reprezentat pe plan și de Vasile Pârvan în urmă cu peste un secol (Pl. II/1). În extremitatea estică a necropolei de la Barboși au fost identificați mai mulți tumuli în zona numită convențional „,cartierul Dunărea ${ }^{30}$ ".

În anul 1867, pe teritoriul orașului Galați, pe strada Lozoveni (nr. 466), în continuarea drumului spre Nord ${ }^{31}$, a fost descoperit fortuit așa-numitul sarcofag ,mithraic”, ${ }^{, 2}$. Tumulul din care face parte acest sarcofag aparține șirului de tumuli de pe „Bulevardul George Coșbuc”. Un șir interesant de tumuli este cel atestat, prin săpături și documente, pe traseul bulevardului George Coșbuc, pe toată lungimea acestuia, care apoi continua pe strada Traian până la ieșirea din municipiu. Este vorba de 24 de tumuli, dispuși într-un șir pe direcția N-S, pe o distanță de 5,20 km. O parte dintre aceștia au fost cercetați, o parte sunt doar menționați în documente de arhivă.

Analizând situația de ansamblu, pe harta mărită a zonei (PI. IX) observăm faptul că acest șir de tumuli este aliniat pe muchia celei mai înalte curbe de nivel din zonă. Din zona bulevardului George Coşbuc terenul coboară ușor spre Lacul Brateș, bulevardul fiind construit pe curba cea mai înaltă de nivel (PI. VII). Cunoscând faptul că necropolele tumulare, cu sarcofage sau alt astfel de monumente funerare, erau amplasate de-a lungul drumurilor în perioada romană, este poate mai mult decât o coincidență faptul că și astăzi cel mai lung și important bulevard din municipiul Galați se află amplasat exact pe același traseu cu cel al tumulilor antici. Acest fapt confirmă o realitate arheologică des întâlnită: drumurile actuale adesea intersectează, dar mai ales suprapun, pe cele din

${ }^{25}$ Țentea, Oltean 2009, 1515-1524.

${ }^{26}$ Pârvan 1913, 118, fig. 13; ISM V 300.

${ }^{27}$ Brudiu 1976, 85-96.

${ }^{28}$ Dragomir 1981, 73-114 = Dragomir 1996, 535-566; Dragomir 1991, 237-245 = Dragomir 1996, 525-534; Sanie 1981, 81-84.

${ }^{29}$ Ilie et alii 2010, 265-266, nr. 124.

${ }^{30}$ Vezi nota 16.

${ }^{31}$ Teoretic, descoperirile funerare din arealul necropolei romane ar fi trebuit să fie dispuse de-a lungul unei artere rutiere principale sau în imediata vecinătate a acestui drum. Luând în calcul acest criteriu și modalitatea de distribuire a necropolei romane, cursul drumului roman se abate semnificativ în directia NE, ajungând la Sud de Lacul Brateș. În aceste condiții ipoteza potrivit căreia acest drum ar fi oferit posibilitatea traversării Dunării printr-un vad situat în proximitatea confluenței Siretului cu Dunărea nu mai corespunde realității. Existența unui vad în această porțiune a Dunării este greu de imaginat (Țentea 2016).

32 Păltănea 1972, 383-385. 
perioadă romană. Dacă peisajul geologic rămâne în mare parte neschimbat, ruta cea mai accesibilă (căutată de topografii romani și contemporani deopotrivă) rămâne mereu aceeași.

\section{Aliniamentele de tumuli din zona Bălții Mălina}

Perieghezele efectuate în urma analizei rezultatelor obținute din fotografiile aeriene din anii precedenți, au avut rezultate foarte bune în zona Bălții Mălina, pe versanții vestic și estic (PI. IX, cu detaliu la PI. XII-XIII). Pe versantul vestic al bălții am reușit să cartăm 24 de tumuli dispuși în șir pe direcția N-S, pe o distanță de 4,16 km (PI. XII, nr. 275-284, 212-223, 490-491). Unii dintre acești tumuli sunt de dimensiuni mari, fiind vizibili de pe versantul estic al bălții, pe linia orizontului (PI. XX/1). Periegheza din anul 2010 efectuată în această zonă a prilejuit o serie de descoperiri de fragmente ceramice în perimetrul tumulilor (PI. XXI), aceasta cu toate că zona este în continuare intens utilizată în scop agricol. Mare parte din fragmentele ceramice sunt atipice și de mici dimensiuni, dar unele păstrează încă indicii tipologice, precum fragmente de toarte de amfore romane timpurii. Având în vedere dispunerea acestor tumuli, dar și materialul descoperit în proximitatea lor, putem considera că pe versantul vestic al Bălții Mălina există o necropolă romană tumulară

De asemenea, pe versantul estic al Bălții Mălina, în vecinătatea combinatului siderurgic, în cadrul perieghezelor din anul 2010, au fost cartați un număr de 66 de tumuli, dintre care 54 sunt mai grupați, alți 12, deși aliniați cu ceilalți, sunt situaţi mai departe, spre nord (PI. XIII, nr. 406417, 422-437, 439-453, 249-271). Tumulii sunt dispuși într-un șir cu aglomerări, ce se întinde pe o distanță de 3,50 km (5 km incluzând cei 12 tumuli din zona nordică). Necropola de aici este suprapusă, în bună măsură de o rețea de tranșee și de cazemate care au făcut parte din linia defensivă Focşani - Nămoloasa - Galați. Materialul arheologic recoltat în periegheză este compus din numeroase fragmente ceramice de factură romană (PI. XXII). Situaţia materialului se prezintă similar celui de pe versantul vestic, mare parte din acesta fiind fragmentar, atipic și nedeterminabil din punct de vedere cronologic. Destule fragmente păstrează, însă, caracteristicile tipologice ceramicii romane timpurii, precum câteva toarte de amforă, o buză de oală, un fragment de mortarium etc.

Cele două grupuri de tumuli din zona Bălții Mălina au unele caracteristici similare, precum faptul că urmăresc în dispunerea tumulilor cele mai înalte curbe de nivel, respectiv linia orizontului (pentru o imagine mai clară privind relieful zone vezi PI. VII). Grupul de tumuli Mălina 1 (de pe versantul vestic, PI. XII) este diferit față de cel denumit Mălina 2 prin faptul că are tumulii dispuși în șir liniar, aceștia sunt de dimensiuni mai mari, iar distanțele dintre ei sunt mai ample. Pe de altă parte, putem lua în considerare şi faptul că această zonă este şi astăzi utilizată pentru lucrări agricole intensive, fapt care a condus la aplatizarea unor tumuli, până la dispariția completă a volumetriei acestora. O parte din informația despre existența acestora a fost recuperată din fotografiile satelitare, aeriene sau din hărțile mai vechi. În același timp, este posibil ca terenul pe care sunt amplasați tumulii din grupul Mălina 2, aflat foarte aproape de combinatul siderurgic, să nu fi fost prea intens cultivat astfel încât aici să se fi păstrat o imagine mai fidelă a peisajului funerar antic.

\section{Grupul de tumuli Pădurea Gârboavele}

O altă zonă ce prezintă interes arheologic este un platou situat la Vest de localitatea Odaia Manolache și la Est de comuna Şendreni (PI. V), cu o suprafață de aproximativ $4 \mathrm{~km}^{2}$. În acest loc peisajul arheologic este foarte complex „Valul lui Traian” străbate platoul amintit în direcția V-E. La Nord de zona descrisă se află pădurea Gârboavele, un spațiu de agrement pentru locuitorii din municipiul Galați. În acest areal am cartat un număr de 37 de tumuli, dispuşi în grup, fără vreun aliniament evident (PI. XIV, nr. 311-347). Ceramica recoltată în periegheza efectuată aici este de factură romană $(\mathbf{P I}$. XXI). Totuși fără cercetări detaliate nu putem suș̦ine faptul că toți acești tumuli datează din epoca romană. 


\section{Șirul de tumuli din zona Lacului Lozova}

Momentan nu deținem informații privind datarea sau apartenența culturală a tumulilor cartați la Nord de localitatea Vasile Alecsandri și la Vest de lacul Lozova (PI. XII, nr. 126-152, 156-159). Este vorba de un șir de 29 de tumuli, dispuși pe direcția NV-SE pe o distanță de cca $3,60 \mathrm{~km}$, pe versantul vestic al văii Lozova. În lipsa materialului arheologic se poate face doar următoarea observație: dispunerea, orientarea și poziția (pe curba de nivel dominantă) sunt similare cu cazurile de la Balta Mălina și chiar Bulevardul George Coșbuc.

\section{ÎN LOC DE CONCLUZII}

Analizarea aproape exhaustivă a distribuției spațiale a complexelor funerare din acest spațiu oferă doar câteva linii directoare privind dispunerea tumulilor în epoca romană. Nu se poate observa o dispunerea regulată de-a lungul traseului unui drum, care să fie urmată de eventuale parcelări. În general, înşiruirea tumulilor pe anumite aliniamente a fost determinată de configuraţia geografică a terenului, aceștia fiind dispuși pe pozițiile dominante, care ofereau o vizibilitate cât mai mare. Construcțiile și monumentele funerare mai importante sunt dispuse în zonele prin care este foarte probabil să fi trecut drumul roman ${ }^{33}$. O mare parte din materialul de factură romană descoperit în tumuli sau la suprafață, în proximitatea acestora, constituie indicii pentru datarea complexelor, dar nu și argumente pentru apartenența defuncților la o populație romană sau romanizată.

\section{BIBLIOGRAFIE}

Brudiu 1976

Brudiu 1980

Brudiu 1981

Brudiu 1991

Brudiu 1998

Brudiu 2003

Croitoru 2013

Dragomir 1981

Dragomir 1991

Dragomir 1996

Ilie et alii 2010
M. Brudiu, Un cavou roman descoperit la Galați, SCIVA, 27, 1, 1976, p. 85-96

M. Brudiu, Săpăturile de salvare din castellum de pământ (sec. II III e.n.), $M C A, 14,1980$, p. $314-320$

M. Brudiu, Un castellum roman descoperit la Galaţi şi semnificaţia lui, Danubius, 10, 1981, p. 59-72

M. Brudiu, Complexe funerare tumulare din sud-estul Moldovei (I), Peuce, 10, p. 31-56

M. Brudiu, Drumul roman prin Moldova de Jos între intuiţie şi realităţile arheologice, Pontica, 31, 1998, p. 217-225

M. Brudiu, Lumea de sub tumuli din sudul Moldovei. De la indoeuropeni la turanicii târzii - mărturii arheologice, Bucureşti, 2003

C. Croitoru, Galati. Repertoriul descoperirilor arheologice si numismatice, Galați, 2013

I.T. Dragomir, Morminte romane într-un tumul la TirighinaBarboşi în sudul roman al Moldovei, Danubius, 10, 1981, p. 73$114=$ Dragomir 1996, p. 535-566

I.T. Dragomir, Descoperirea fortuită a unui mormânt tumular de incineraţie de la Tirighina - Barboşi, Pontica, 24, 1991, p. 237-245 $=$ Dragomir 1996, p. 525-534

I.T. Dragomir, Monografia arheologică a Moldovei de sud, Danubius, 16, Galați 1996

C. Ilie, A. Adamescu, M. Scripnic, C. Moraru, Galaţi, jud. Galaţi. Punct Tirighina - Necropola tumulară romană. Tumul 1, CCA 2010, p. 265-266

\footnotetext{
${ }^{33}$ Țentea 2016, 12-19.
} 
Jugănaru et alii 2011

Jugănaru et alii 2012

ISM V

Oltean 2013

Oţa 2013

Păltănea 1972

Pârvan 1913

Sanie 1981

Țentea 2007

Tentea 2016

Țentea, Cleşiu 2006

Ţentea, Oltean 2009

G. Jugănaru, Fl. Topoleanu, A. I. Adamescu, V. A. Parnic, Galaţi Cartierul Dunărea. Raport de cercetare arheologică preventivă 2011/Galaţi - Dunărea District. Report of Preventive Archaeological Research, Danubius, 30, 2011, p. 61-76

G. Jugănaru, A. I. Adamescu, V. A. Parnic, Fl. Topoleanu, Galați, Cartier Dunărea, CCA, 2012, p. 216-219, nr. 118

Emilia Doruțiu-Boilă, Inscriptiones Scythiae Minoris, V. Capidava - Noviodunum - Troesmis, Bucureşti, 1980

Ioana A. Oltean, A lost archaeological landscape on the Lower Danube Roman limes: The contribution of second world war aerial photographs, in W. S. hanson, Ioana A. Oltean (eds.), Archaeology from Historical Aerial and Satellite Archives, New York 2013, p. 147-164

Liana Oţa, Lumea funerară în Moesia Inferior (secolele I-III p. Chr.), Brăila, 2013

P. Păltănea, Informaţii arhivistice despre un sarcofag roman de la Galaţi, ArhMold, 7, 1972, p. 383-385

V. Pârvan, Castrul de la Poiana şi drumul roman prin Moldova de Jos, Academia Română, Memoriile Secţiunii Istorice, Bucureşti, II 36/4, 1913, p. 1-38 (14-27)

S. Sanie, Civilizaţia romană de la est de Carpaţi şi romanitatea de pe teritoriul Moldovei, Iaşi, 1981

O. Țentea, Depozite de amfore sau instalaţii militare?, în Doina Benea (ed.), Meşteşuguri şi artizani în Imperiul roman. Cu privire specială asupra Daciei şi provinciilor învecinate (sec. II-IV d.Hr.), Timişoara, 2007, p. 172-181

O. Țentea, On the alleged 'Roman road from Lower Moldavia', The Journal of Ancient History and Archaeology, Cluj-Napoca, 3/1, 2016, p. 12-19

O. Ţentea, S. Cleşiu, Fortificaţia şi necropola romană de la Galaţi, cartier „Dunărea”. Raport arheologic, CA, XIII, 2006, p. 39-88

O. Thentea, Ioana A. Oltean, The Lower Danube Roman Limes at Galaţi (Romania). Recent results from excavation and aerial photographic interpretation, în Limes $X X$ : Proceedings of the $X X^{\text {th }}$ International Congress of Roman Frontier Studies. Papers from the $20^{\text {th }}$ Limes conference, held in Léon, Spain, 2006, Madrid 2009, p. $1515-1524$

LISTA ILUSTRAȚILOR

Pl. I. 1. Traseul drumului roman din Moldova de Jos (după Pârvan 1913, 118, fig. 13); 2. Harta descoperirilor arheologice din zona Barboși - Galați (după Gostar 1962, 506, fig. 1)

PI. II. 1. Planul fortificației romane și a necropolei de la Barboși - Pârvan 1913, 111, fig. 9; 2. Planul fortificațiilor și necropolei romane de la Barboși, incluzând și cercetările din cartierul Dunărea, Galați (după Țentea 2007, 224 fig. 1)

PI. III. Harta tumulilor din zona sud-vestului Moldovei (după Brudiu 2003, 158 fig. 3)

PI. IV. 1. Date arheologice transcrise după fotografii aeriene realizate în anul 1944 (Țentea, Oltean 2009, 1519 fig. 3); 2. Interpretarea distribuției vestigiilor arheologice din interiorul „Valului lui 
Traian"-Tulucești, după fotografiile aeriene realizate în anul 1944 (Țentea, Oltean 2009, 1521 fig. 4)

PI. V. Descoperiri antice și contemporane detaliate pe Planurile Directoare de Tragere (PDT) http://www.geo-spatial.org/download/planurile-directoare-de-tragere

PI. VI. Descoperiri antice și contemporane detaliate pe Planurile Directoare de Tragere (detaliu cu zona municipiului Galați)

PI. VII. Harta descoperirilor funerare din arealul confluenței râului Siret cu Dunărea - Digital Terrain Model (DTM) - Mihai Florea

PI. VIII. Harta descoperirilor funerare din arealul confluenței râului Siret cu Dunărea - zonele administrative

PI. IX. Harta descoperirilor funerare din arealul confluenței râului Siret cu Dunărea

PI. X. Harta descoperirilor funerare din arealul confluenței râului Siret cu Dunărea - marcarea zonelor de detaliere

PI. XI. Harta detaliată a descoperirilor funerare din zona Tirighina - Barboși și Cartierul Dunărea Galați (I)

PI. XII. Harta detaliată a descoperirilor funerare din zona „Valul lui Traian” - Braniștea - Șendreni (II)

PI. XIII. Harta detaliată a descoperirilor funerare din zona de Nord a municipiului Galați (III)

PI. XIV. Harta detaliată a descoperirilor funerare din zona de Nord a „Valului lui Traian” (IV)

PI. XV. Harta detaliată a descoperirilor funerare din zona de nord a comunei Șivița (V)

PI. XVI. 1. Tumulii 184, 185 și 186 situați la Est de comuna Braniștea - fotografie aeriană din anul 2008; 2. Tumulul 184 (Movila Braniștea), fotografie aeriană - detaliu

PI. XVII. 1. Tumulul 415 („Movila Cracul Făloaiei”) situată la Est de comuna Smârdan; 2. Tumulul 438 („Movila Vășmășeanca”) situată în Sudul comunei Smârdan - fotografii aeriene din anul 2008

PI. XVIII. 1. Tumulul 212 situat la Est de Pădurea Gârboavele și la Vest de satul Tulucești; 2. Tumulul 312 situat la Vest de Balta Mălina - periegheză din anul 2010

PI. XIX. 1. „Valul lui Traian” (stânga). Pe fundal satul Traian; 2. Tumulul 281, situat la Sud-Est de comuna Smârdan - periegheză din anul 2012

PI. XX. 1. Vedere panoramică cu malul vestic al Bălții Mălina (com. Smârdan); 2. Vedere panoramică cu zona aflată la Est de comuna Braniștea - periegheză din anul 2012

PI. XXI. Fragmente de ceramică romană descoperite în perieghezele efectuate în anul 2010

PI. XXII. Fragmente de ceramică romană descoperite în perieghezele efectuate în anul 2012

\section{LIST OF ILLUSTRATIONS}

PI. I. 1. The Roman road from Lower Moldovia (Moldova de Jos) - after Pârvan 1913, 118, fig. 13;

2. The map of the archaeological discoveries from Barboși area - Galați (after Gostar 1962, 506, fig. 1)

PI. II. 1. The plan of the Roman fortifications and of the Roman necropolis from Barboși - Pârvan 1913, 111, fig. 9; 2. The plan of the fortifications and of the Roman necropolis from Barboși, including the research from Dunărea neighbourhood, Galați (after Țentea 2007, 224, fig. 1)

PI. III. The map of the tumuli from south-west Moldova. (after Brudiu 2003, 158 fig. 3)

PI. IV. 1. Archaeological data transcribed after aerial photos carried out in 1944 (T,entea, Oltean 2009, 1519, fig. 3); 2. The interpretation of the distribution of the archaeological discoveries found inside "Valul lui Traian" - Tulucești, according to the aerial photos from 1944 (Țentea, Oltean 2009, 1521, fig. 4)

Pl. V. Ancient and contemporary discoveries detailed on Romanian maps under 'LambertCholesky' (1916-1959) projection system - http://www.geo-spatial.org/download/planuriledirectoare-de-tragere 
PI. VI. Ancient and contemporary discoveries detailed on Romanian maps under 'LambertCholesky' (1916-1959) projection system (detail on the Galați city area)

PI. VII. The map of funerary discoveries from the area of the confluence of Siret River with the Danube - Digital Terrain Model (DTM), courtesy of Mihai Florea

PI. VIII. The map of the funerary discoveries from the area of the confluence of Siret River with the Danube - the administrative areas

PI. IX. The map of the funerary discoveries from the area of the confluence of Siret River with the Danube

PI. X. The map of the funerary discoveries from the area of the confluence of Siret River with the Danube - detailed areas

PI. XI. The detailed map if the funerary finds from the area Tirighina - Barboși and Dunărea district from Galați (I)

PI. XII. The detailed map of the funerary finds from the area "Valul lui Traian" - Braniștea Şendreni (II)

PI. XIII. Detailed map of the funerary finds from the North area of Galați (III)

PI. XIV. The detailed map of the funerary discoveries from the north area of "Valul lui Traian" (IV)

Pl. XV. The detailed map of the funerary discoveries from the north area of Şivița (V)

Pl. XVI. 1. Tumuli 184, 185 and 186 situated east of Braniștea commune - aerial photo from 2008;

2. Tumulus 184 (Movila Braniștea), aerial photo - detail

PI. XVII. 1. Tumulus 415 ("Movila Cracul Făloaiei") situated east of Smârdan commune; 2. Tumulus 438 ("Movila Vășmășeanca") situated south of Smârdan commune - aerial photos from 2008

PI. XVIII. 1. Tumulus 212 situated east of Pădurea Gârboavele, west of Tulucești; 2. Tumulus 312 situated west of Balta Mălina - field survey 2010

PI. XIX. 1. „Valul lui Traian” (left). In the background: Traian village; 2. Tumulus 281, situated south-east of Smârdan commune - field survey from 2012

PI. XX. 1. Panoramic view of the western bank of Balta Mălina (Smârdan commune); 2. Panoramic view of the eastern area of Braniștea commune - field survey from 2012

PI. XXI. Roman ceramic fragments discovered in the field surveys carried out in 2010

PI. XXII. Roman ceramic fragments discovered in the field surveys carried out in 2012

OVIDIU ȚENTEA, ALEXANDRU RAȚIU

Muzeul Naţional de Istorie a României ovidiu.tentea@gmail.com sandu_ratiu@yahoo.com 


\begin{tabular}{|c|c|c|c|c|c|c|c|c|c|}
\hline $\begin{array}{l}\text { Nr. } \\
\text { crt. }\end{array}$ & Toponim & Administrativ & B & $\mathbf{C}$ & $\mathbf{F}$ & $\mathbf{T}$ & Descriere & Localizare & Bibliografie \\
\hline 1 & Neprecizat & $\begin{array}{l}\text { Liești (com.), } \\
\text { Liești }\end{array}$ & & $\mathbf{C}$ & & & - & La 3 km nord-est de nr. 2 . & - \\
\hline 2 & $\begin{array}{l}\text { Movila lui } \\
\text { Florea } \\
\text { (Movila } \\
\text { Chitului) }\end{array}$ & $\begin{array}{l}\text { Liești (com.), } \\
\text { Liești }\end{array}$ & $\mathbf{B}$ & $\mathbf{C}$ & & & Dimensiuni: diam. 70 m, h. 7 m. & $\begin{array}{l}\text { Se află pe un interfluviu la } \\
300 \text { m vest de Călmățui, } \\
\text { numit muchea Vâlcea. }\end{array}$ & $\begin{array}{l}\text { Brudiu 1991, 48; } \\
\text { Brudiu 2003, 102, nr. } \\
\text { 93. }\end{array}$ \\
\hline 3 & Neprecizat & $\begin{array}{l}\text { Liești (com.), } \\
\text { Liești }\end{array}$ & B & $\mathbf{C}$ & & & Dimensiuni: diam. 40 m, h. 3 m. & $\begin{array}{l}\text { Se află la est de valea } \\
\text { Călmățui la } 2,50 \mathrm{~km} \text { nord } \\
\text { de Movila Sturoiu (nr.4). }\end{array}$ & $\begin{array}{l}\text { Brudiu 1991, 48; } \\
\text { Brudiu 2003, 103, nr. } \\
95 .\end{array}$ \\
\hline 4 & $\begin{array}{l}\text { Movila } \\
\text { Sturoiu }\end{array}$ & $\begin{array}{l}\text { Liești (com.), } \\
\text { Liești }\end{array}$ & B & $\mathbf{C}$ & $\mathbf{F}$ & & Dimensiuni: diam. 35 m, h. 2 m. & $\begin{array}{l}\text { La marginea vestică a } \\
\text { interfluviului dintre văile } \\
\text { Gerului și Călmățui. }\end{array}$ & $\begin{array}{l}\text { Brudiu 1991, 49; } \\
\text { Brudiu 2003, 103, nr. } \\
110 .\end{array}$ \\
\hline 5 & $\begin{array}{c}\text { Movila } \\
\text { Gavrilițăa }\end{array}$ & $\begin{array}{l}\text { Liești (com.), } \\
\text { Liești }\end{array}$ & B & $\mathbf{C}$ & $\mathbf{F}$ & & Dimensiuni: diam. 25 m, h. 1 m. & $\begin{array}{l}\text { La est de confluența unei } \\
\text { văi scurte cu Valea } \\
\text { Călmățui. }\end{array}$ & $\begin{array}{l}\text { Brudiu 1991, 48; } \\
\text { Brudiu 2003, 102, nr. } \\
83 .\end{array}$ \\
\hline 6 & Neprecizat & $\begin{array}{l}\text { Liești (com.), } \\
\text { Liești }\end{array}$ & & C & & & - & La 3,80 km nord de nr. 5 . & - \\
\hline 7 & Neprecizat & $\begin{array}{l}\text { Liești (com.), } \\
\text { Liești }\end{array}$ & & $\mathbf{C}$ & $\mathbf{F}$ & & - & La $130 \mathrm{~m}$ sud de nr. 6 . & - \\
\hline 8 & $\begin{array}{l}\text { Movila } \\
\text { Negre }\end{array}$ & $\begin{array}{l}\text { Liești (com.), } \\
\text { Liești }\end{array}$ & & $\mathbf{C}$ & $\mathbf{F}$ & & - & La 2,20 km sud-est de nr. 6 . & - \\
\hline 9 & $\begin{array}{c}\text { Movila } \\
\text { Erbănașu }\end{array}$ & $\begin{array}{c}\text { Liești (com.), } \\
\text { Liești } \\
\end{array}$ & & $\mathbf{C}$ & & & - & $\begin{array}{l}\text { La } 1,10 \mathrm{~km} \text { nord est de nr. } \\
8 .\end{array}$ & - \\
\hline 10 & Neprecizat & $\begin{array}{l}\text { Liești (com.), } \\
\text { Liești }\end{array}$ & B & $\mathbf{C}$ & $\mathbf{F}$ & & Dimensiuni: diam. 40 m, h. 2 m. & $\begin{array}{l}\text { În albia majoră a Văii } \\
\text { Gerului la } 60 \text { m sud de } \\
\text { sifonul CP5. }\end{array}$ & $\begin{array}{l}\text { Brudiu 2003, 121-122, } \\
\text { nr. } 298 .\end{array}$ \\
\hline 11 & Neprecizat & $\begin{array}{l}\text { Liești (com.), } \\
\text { Liești }\end{array}$ & B & & & & Dimensiuni: diam. 40 m, h. 2 m. & La $1,40 \mathrm{~km}$ sud-est de nr. 5 . & $\begin{array}{l}\text { Brudiu 1991, 48; } \\
\text { Brudiu 2003, 102, nr. } \\
84 .\end{array}$ \\
\hline 12 & Neprecizat & $\begin{array}{l}\text { Liești (com.), } \\
\text { Liești }\end{array}$ & & $\mathbf{C}$ & & & - & La 2,90 km vest de nr. 5 . & - \\
\hline 13 & Neprecizat & $\begin{array}{l}\text { Liești (com.), } \\
\text { Lieşti }\end{array}$ & $\mathbf{B}$ & & $\mathbf{F}$ & & Dimensiuni: diam. 35 m, h. 2 m. & $\begin{array}{l}\text { Se află la } 1 \text { km sud-est de } \\
\text { nr. } 14 .\end{array}$ & $\begin{array}{l}\text { Brudiu 1991, 48; } \\
\text { Brudiu 2003, 103, nr. } \\
96 .\end{array}$ \\
\hline 14 & Neprecizat & $\begin{array}{l}\text { Liești (com.), } \\
\text { Liești }\end{array}$ & B & & & & Dimensiuni: diam. 310 m, h. 2 m. & La $200 \mathrm{~m}$ sud de nr. 11. & $\begin{array}{l}\text { Brudiu 1991, 48; } \\
\text { Brudiu 2003, 102, nr. } \\
85 .\end{array}$ \\
\hline 15 & Neprecizat & $\begin{array}{l}\text { Liești (com.), } \\
\text { Liești }\end{array}$ & $\mathbf{B}$ & & & & Dimensiuni: diam. 27 m, h. 1 m. & $\begin{array}{l}\text { Se află la obârşia unei văi } \\
\text { seci, confluentă cu Valea } \\
\text { Gerului. }\end{array}$ & $\begin{array}{l}\text { Brudiu 1991, 48; } \\
\text { Brudiu 2003, 102, nr. } \\
86 .\end{array}$ \\
\hline
\end{tabular}




\begin{tabular}{|c|c|c|c|c|c|c|c|c|c|}
\hline $\begin{array}{l}\text { Nr. } \\
\text { crt. }\end{array}$ & Toponim & Administrativ & B & $\mathbf{C}$ & $\mathbf{F}$ & $\mathbf{T}$ & Descriere & Localizare & Bibliografie \\
\hline
\end{tabular}

\begin{tabular}{|c|c|c|c|c|c|c|c|c|}
\hline 16 & Neprecizat & $\begin{array}{l}\text { Liești (com.), } \\
\text { Liești }\end{array}$ & B & & & Dimensiuni: diam. 33 m, h. 2 m. & $\begin{array}{l}\text { La } 400 \text { m nord-est de nr. 19, } \\
\text { la marginea estică a } \\
\text { interfluviului dintre văile } \\
\text { Gerului și Călmățui. }\end{array}$ & $\begin{array}{l}\text { Brudiu 1991, 48; } \\
\text { Brudiu 2003, 102, nr. } \\
89 .\end{array}$ \\
\hline 17 & Neprecizat & $\begin{array}{l}\text { Liești (com.), } \\
\text { Liești }\end{array}$ & & $\mathbf{C}$ & $\mathbf{F}$ & - & La 700 m est de nr. 16. & - \\
\hline 18 & Neprecizat & $\begin{array}{l}\text { Liești (com.), } \\
\text { Liești }\end{array}$ & B & & & Dimensiuni: diam. 35 m, h. 2 m. & $\begin{array}{l}\text { Se află la } 1 \mathrm{~km} \text { est de } \\
\text { plantația de salcâmi, aflată } \\
\text { la rândul său la est de satul } \\
\text { Liești. }\end{array}$ & $\begin{array}{l}\text { Brudiu 1991, 48; } \\
\text { Brudiu 2003, 103, nr. } \\
94 .\end{array}$ \\
\hline 19 & Neprecizat & $\begin{array}{l}\text { Liești (com.), } \\
\text { Liești }\end{array}$ & B & $\mathbf{C}$ & & Dimensiuni: diam. 35 m, h. 2 m. & $\begin{array}{l}\text { La cca } 1 \mathrm{~km} \text { sud-est de nr. } \\
21 .\end{array}$ & $\begin{array}{l}\text { Brudiu 1991, 48; } \\
\text { Brudiu 2003, 102, nr. } \\
88 .\end{array}$ \\
\hline 20 & $\begin{array}{l}\text { Movila } \\
\text { Ranete }\end{array}$ & $\begin{array}{l}\text { Liești (com.), } \\
\text { Liești }\end{array}$ & B & $\mathbf{C}$ & $\mathbf{F}$ & Dimensiuni: diam. 40 m, h. 2 m. & $\begin{array}{l}\text { Se află la } 1,50 \mathrm{~km} \text { de } \\
\text { conducta de gaz metan. }\end{array}$ & $\begin{array}{l}\text { Brudiu 1991, 48; } \\
\text { Brudiu 2003, 103, nr. } \\
97 .\end{array}$ \\
\hline 21 & Neprecizat & $\begin{array}{l}\text { Liești (com.), } \\
\text { Liești }\end{array}$ & B & & & Dimensiuni: diam. 25 m, h. 1 m. & $\begin{array}{l}\text { Se află la est de altă vale } \\
\text { seacă, confluentă şi ea cu } \\
\text { Valea Gerului. }\end{array}$ & $\begin{array}{l}\text { Brudiu 1991, 48; } \\
\text { Brudiu 2003, 102, nr. } \\
87 .\end{array}$ \\
\hline 22 & Neprecizat & $\begin{array}{l}\text { Liești (com.), } \\
\text { Liești }\end{array}$ & B & & & Dimensiuni: diam. 30 m, h. 1 m. & La 1 km sud de nr. 19. & $\begin{array}{l}\text { Brudiu 1991, 48; } \\
\text { Brudiu 2003, 102, nr. } \\
\text { 91. }\end{array}$ \\
\hline 23 & Neprecizat & $\begin{array}{l}\text { Liești (com.), } \\
\text { Liești }\end{array}$ & B & & & Dimensiuni: diam. 30 m, h. 1 m. & $\begin{array}{l}\text { Se află pe un interfluviu } \\
\text { dintre două văi seci la } 500 \\
\text { m sud est de nr. } 15 \text {. }\end{array}$ & $\begin{array}{l}\text { Brudiu 1991, 48; } \\
\text { Brudiu 2003, 102, nr. } \\
92 .\end{array}$ \\
\hline 24 & $\begin{array}{l}\text { Movila } \\
\text { Ciofrești }\end{array}$ & $\begin{array}{c}\text { Tudor } \\
\text { Vladimirescu } \\
\text { (com.), sat Tudor } \\
\text { Vladimirescu } \\
\end{array}$ & B & $\mathbf{C}$ & & Dimensiuni: diam. 60 m, h. 4 m. & $\begin{array}{l}\text { La } 2 \text { km vest de Movila } \\
\text { Gurguiată (nr. 35). }\end{array}$ & $\begin{array}{l}\text { Brudiu 1991, 49, 109; } \\
\text { Brudiu 2003, 93-136, } \\
\text { nr. } 109 .\end{array}$ \\
\hline 25 & Neprecizat & $\begin{array}{c}\text { Tudor } \\
\text { Vladimirescu } \\
\text { (com.), sat Tudor } \\
\text { Vladimirescu } \\
\end{array}$ & B & & & Dimensiuni: diam. 40 m, h. 2 m. & $\begin{array}{l}\text { La est de drumul ce leagă } \\
\text { localitatea de Mănăstirea } \\
\text { „T. Vladimirescu”. }\end{array}$ & $\begin{array}{l}\text { Brudiu 1991, 49, 117; } \\
\text { Brudiu 2003, 93-136, } \\
\text { nr. } 117 .\end{array}$ \\
\hline 26 & Neprecizat & $\begin{array}{c}\text { Tudor } \\
\text { Vladimirescu } \\
\text { (com.), sat Tudor } \\
\text { Vladimirescu }\end{array}$ & B & & & $\begin{array}{l}\text { Tumul nivelat în anul 1990, când s-au distrus și niște morminte asociate } \\
\text { contextual cu aceasta. Nu se menționează nimic referitor la numărul sau } \\
\text { datarea complexelor. }\end{array}$ & $\begin{array}{l}\text { La nord-est de localitate, la } \\
1,70 \mathrm{~km} \text { sud de nr. } 25 \text {. }\end{array}$ & $\begin{array}{l}\text { Brudiu 2003, 93-136, } \\
\text { nr. } 118 .\end{array}$ \\
\hline 27 & Neprecizat & $\begin{array}{l}\text { Tudor } \\
\text { Vladimirescu } \\
\text { (com.), sat Tudor } \\
\text { Vladimirescu }\end{array}$ & B & & & Dimensiuni: diam. 25 m, h. 1 m. & $\begin{array}{l}\text { La marginea de nord-est a } \\
\text { localității. }\end{array}$ & $\begin{array}{l}\text { Brudiu 1991, 49, 118; } \\
\text { Brudiu 2003, 93-136, } \\
\text { nr. 118. }\end{array}$ \\
\hline
\end{tabular}




\begin{tabular}{|c|c|c|c|c|c|c|c|c|c|}
\hline $\begin{array}{l}\text { Nr. } \\
\text { crt. }\end{array}$ & Toponim & Administrativ & B & $\mathbf{C}$ & $\mathbf{F}$ & $\mathbf{T}$ & Descriere & Localizare & Bibliografie \\
\hline
\end{tabular}

\begin{tabular}{|c|c|c|c|c|c|c|c|c|}
\hline 28 & $\begin{array}{l}\text { Movila } \\
\text { Shioldun }\end{array}$ & $\begin{array}{c}\text { Tudor } \\
\text { Vladimirescu } \\
\text { (com.), sat Tudor } \\
\text { Vladimirescu } \\
\end{array}$ & & $\mathbf{C}$ & $\mathbf{F}$ & - & $\begin{array}{l}\text { La } 1,50 \mathrm{~km} \text { nord de sat, la } \\
1,20 \mathrm{~km} \text { vest de nr. } 33 .\end{array}$ & - \\
\hline 29 & Neprecizat & $\begin{array}{c}\text { Tudor } \\
\text { Vladimirescu } \\
\text { (com.), sat Tudor } \\
\text { Vladimirescu } \\
\end{array}$ & & $\mathbf{C}$ & & - & La 950 m nord de nr. 30. & - \\
\hline 30 & Neprecizat & $\begin{array}{c}\text { Tudor } \\
\text { Vladimirescu } \\
\text { (com.), sat Tudor } \\
\text { Vladimirescu } \\
\end{array}$ & & & & - & $\begin{array}{l}\text { La } 1,30 \mathrm{~km} \text { est de } \mathrm{nr} .26 \text {, la } \\
\text { cca } 2,50 \mathrm{~km} \text { nord-est de sat. }\end{array}$ & - \\
\hline 31 & $\begin{array}{l}\text { Movila } \\
\text { Tălăbasca }\end{array}$ & $\begin{array}{c}\text { Tudor } \\
\text { Vladimirescu } \\
\text { (com.), sat Tudor } \\
\text { Vladimirescu } \\
\end{array}$ & & $\mathbf{C}$ & & - & $\begin{array}{l}\text { La sud vest de sat, la } 60 \text { m } \\
\text { est de Balta Tălăbasca. }\end{array}$ & - \\
\hline 32 & Neprecizat & $\begin{array}{c}\text { Tudor } \\
\text { Vladimirescu } \\
\text { (com.), sat Tudor } \\
\text { Vladimirescu } \\
\end{array}$ & B & & & Dimensiuni: diam. 25 m, h. 2,50 m. & $\begin{array}{l}\text { Imprecis; se menționează } \\
\text { doar: „la marginea terasei } \\
\text { inferioare”. }\end{array}$ & $\begin{array}{l}\text { Brudiu 1991, 49, 121; } \\
\text { Brudiu 2003, 93-136, } \\
\text { nr. } 121 .\end{array}$ \\
\hline 33 & Neprecizat & $\begin{array}{c}\text { Tudor } \\
\text { Vladimirescu } \\
\text { (com.), sat Tudor } \\
\text { Vladimirescu } \\
\end{array}$ & & & $\mathbf{F}$ & - & $\begin{array}{l}\text { La 1,30 km est de nr. } 28 \text {, în } \\
\text { zona de nord-nord-est a } \\
\text { satului, la cca } 1,50 \mathrm{~km} \\
\text { distanță de acesta. }\end{array}$ & - \\
\hline 34 & Neprecizat & $\begin{array}{c}\text { Tudor } \\
\text { Vladimirescu } \\
\text { (com.), sat Tudor } \\
\text { Vladimirescu } \\
\end{array}$ & B & & & Dimensiuni: diam. 70 m, h. 4 m. & $\begin{array}{l}\text { La } 1 \mathrm{~km} \text { sud-vest de Movila } \\
\text { Gurguița (nr. 35). }\end{array}$ & $\begin{array}{l}\text { Brudiu 1991, 49, 107; } \\
\text { Brudiu 2003, 93-136, } \\
\text { nr. } 107 .\end{array}$ \\
\hline 35 & $\begin{array}{l}\text { Movila } \\
\text { Gurguița } \\
\text { (M-la } \\
\text { Gurguiată) }\end{array}$ & $\begin{array}{c}\text { Tudor } \\
\text { Vladimirescu } \\
\text { (com.), sat Tudor } \\
\text { Vladimirescu }\end{array}$ & B & $\mathbf{C}$ & $\mathbf{F}$ & Dimensiuni: diam. 70 m, h. 5 m. & $\begin{array}{l}\mathrm{La} 6 \mathrm{~km} \text { nord-est de } \\
\text { localitate și la } 1,50 \mathrm{~km} \text { vest } \\
\text { de canalul Gerului. }\end{array}$ & $\begin{array}{l}\text { Brudiu 1991, 49, 108; } \\
\text { Brudiu 2003, 93-136, } \\
\text { nr. } 108 .\end{array}$ \\
\hline 36 & Neprecizat & $\begin{array}{c}\text { Tudor } \\
\text { Vladimirescu } \\
\text { (com.), sat Tudor } \\
\text { Vladimirescu }\end{array}$ & B & & & Dimensiuni: diam. 35 m, h. 2 m. & $\begin{array}{l}\text { La } 900 \text { m vest de Canalul } \\
\text { gerului și la } 500 \text { m nord- } \\
\text { vest de obârşia văii Gerului. }\end{array}$ & $\begin{array}{l}\text { Brudiu 1991, 49, 113; } \\
\text { Brudiu 2003, 93-136, } \\
\text { nr. } 113 .\end{array}$ \\
\hline 37 & Neprecizat & $\begin{array}{c}\text { Tudor } \\
\text { Vladimirescu } \\
\text { (com.), sat Tudor } \\
\text { Vladimirescu } \\
\end{array}$ & & $\mathbf{C}$ & & - & La 1,50 km est de nr. 37 . & - \\
\hline 38 & Neprecizat & $\begin{array}{c}\text { Tudor } \\
\text { Vladimirescu } \\
\text { (com.), sat Tudor } \\
\text { Vladimirescu } \\
\end{array}$ & $\mathbf{B}$ & $\mathbf{C}$ & & Dimensiuni: diam. 50 m, h. 3 m. & $\begin{array}{l}\text { Pe valea Gerului, la vest de } \\
\text { canal. }\end{array}$ & $\begin{array}{l}\text { Brudiu 2003, 93-136, } \\
\text { nr. } 303 .\end{array}$ \\
\hline
\end{tabular}




\begin{tabular}{|c|c|c|c|c|c|c|c|c|c|}
\hline $\begin{array}{l}\text { Nr. } \\
\text { crt. }\end{array}$ & Toponim & Administrativ & B & $\mathbf{C}$ & $\mathbf{F}$ & $\mathbf{T}$ & Descriere & Localizare & Bibliografie \\
\hline
\end{tabular}

\begin{tabular}{|c|c|c|c|c|c|c|c|c|}
\hline 39 & Neprecizat & $\begin{array}{c}\text { Tudor } \\
\text { Vladimirescu } \\
\text { (com.), sat Tudor } \\
\text { Vladimirescu }\end{array}$ & & & $\mathbf{F}$ & & $\begin{array}{l}\text { Face parte dintr-un şir de } 6 \\
\text { tumuli ce începe cu Movila } \\
\text { Cailor (nr. 43) și se } \\
\text { sfârșește cu aceasta. Se află } \\
\text { la } 900 \text { m nord de nr. } 40 .\end{array}$ & - \\
\hline 40 & Neprecizat & $\begin{array}{c}\text { Tudor } \\
\text { Vladimirescu } \\
\text { (com.), sat Tudor } \\
\text { Vladimirescu } \\
\end{array}$ & B & $\mathbf{C}$ & $\mathbf{F}$ & Dimensiuni: diam. 30 m, h. 1 m. & $\begin{array}{l}\text { Lângă Mănăstirea „T. } \\
\text { Vladimirescu” la confluența } \\
\text { unei văi seci cu valea } \\
\text { Gerului. }\end{array}$ & $\begin{array}{l}\text { Brudiu 1991, 49, 124; } \\
\text { Brudiu 2003, 93-136, } \\
\text { nr. } 124 .\end{array}$ \\
\hline 41 & $\begin{array}{l}\text { Movila } \\
\text { Bujoreanu }\end{array}$ & $\begin{array}{c}\text { Tudor } \\
\text { Vladimirescu } \\
\text { (com.), sat Tudor } \\
\text { Vladimirescu } \\
\end{array}$ & B & $\mathbf{C}$ & $\mathbf{F}$ & Dimensiuni: diam. 40 m, h. 2 m. & $\begin{array}{l}\text { La } 3 \mathrm{~km} \text { nord de calea } \\
\text { ferată şi la } 450 \mathrm{~m} \text { vest de } \\
\text { valea Gerului. }\end{array}$ & $\begin{array}{l}\text { Brudiu 1991, 49, 123; } \\
\text { Brudiu 2003, 93-136, } \\
\text { nr. } 123 .\end{array}$ \\
\hline 42 & Neprecizat & $\begin{array}{c}\text { Tudor } \\
\text { Vladimirescu } \\
\text { (com.), sat Tudor } \\
\text { Vladimirescu }\end{array}$ & B & & $\mathbf{F}$ & Dimensiuni: diam. 35 m, h. 1 m. & $\begin{array}{l}\text { La } 450 \text { m sud de Movila } \\
\text { Bujoreanu (nr. 41). }\end{array}$ & $\begin{array}{l}\text { Brudiu 1991, 49, 122; } \\
\text { Brudiu 2003, 93-136, } \\
\text { nr. } 122 .\end{array}$ \\
\hline 43 & $\begin{array}{l}\text { Movila } \\
\text { Cailor }\end{array}$ & $\begin{array}{c}\text { Tudor } \\
\text { Vladimirescu } \\
\text { (com.), sat Tudor } \\
\text { Vladimirescu } \\
\end{array}$ & B & $\mathbf{C}$ & $\mathbf{F}$ & Dimensiuni: diam. 30 m, h. 1 m. & $\begin{array}{l}\text { La 2,30 km est de localitate, } \\
\text { la marginea drumului } \\
\text { Galați-Tecuci, la } 300 \mathrm{~m} \\
\text { nord de acesta. }\end{array}$ & $\begin{array}{l}\text { Brudiu 1991, 49, 119; } \\
\text { Brudiu 2003, 93-136, } \\
\text { nr. } 119 .\end{array}$ \\
\hline 44 & $\begin{array}{l}\text { Movila } \\
\text { Lunca } \\
\text { Gerului }\end{array}$ & $\begin{array}{c}\text { Tudor } \\
\text { Vladimirescu } \\
\text { (com.), sat Tudor } \\
\text { Vladimirescu } \\
\end{array}$ & B & & & Dimensiuni: diam. 30 m, h. 2 m. & $\begin{array}{l}\text { În valea Gerului, la } 500 \text { m } \\
\text { sud-est de Movila Cailor. }\end{array}$ & $\begin{array}{l}\text { Brudiu 1991, 49, 120; } \\
\text { Brudiu 2003, 93-136, } \\
\text { nr. } 120 .\end{array}$ \\
\hline 45 & Neprecizat & $\begin{array}{c}\text { Tudor } \\
\text { Vladimirescu } \\
\text { (com.), sat Tudor } \\
\text { Vladimirescu }\end{array}$ & & $\mathbf{C}$ & & - & $\begin{array}{l}\text { La cca } 400 \mathrm{~m} \text { sud de } \\
\text { localitate. }\end{array}$ & - \\
\hline 46 & $\begin{array}{l}\text { Movila } \\
\text { Moga }\end{array}$ & $\begin{array}{c}\text { Tudor } \\
\text { Vladimirescu } \\
\text { (com.), sat Tudor } \\
\text { Vladimirescu }\end{array}$ & & $\mathbf{C}$ & & - & $\begin{array}{l}\text { La } 700 \text { m sud-est de } \\
\text { localitate și la } 1 \mathrm{~km} \text { est de } \\
\text { nr. } 45 .\end{array}$ & - \\
\hline 47 & Neprecizat & $\begin{array}{l}\text { Pechea (com.) } \\
\text { Pechea }\end{array}$ & $\mathbf{B}$ & & & Dimensiuni: diam. 30 m, h. 1 m. & $\begin{array}{l}\text { Pe teritoriul fostului IAS } \\
\text { Ivești, la } 400 \text { m nord de } \\
\text { Movila Potârnichea (nr. 49). }\end{array}$ & $\begin{array}{l}\text { Brudiu 2003, 122, nr. } \\
309\end{array}$ \\
\hline 48 & Neprecizat & $\begin{array}{l}\text { Pechea (com.) } \\
\text { Pechea }\end{array}$ & B & & & Dimensiuni: diam. 30 m, h. 0,90 m. & $\begin{array}{l}\text { Pe teritoriul fostului IAS } \\
\text { Ivești, la } 100 \mathrm{~m} \text { sud de } \mathrm{nr} \text {. } \\
47 .\end{array}$ & $\begin{array}{l}\text { Brudiu 2003, 122, nr. } \\
310\end{array}$ \\
\hline 49 & $\begin{array}{l}\text { Movila } \\
\text { Potârnichea }\end{array}$ & $\begin{array}{l}\text { Pechea (com.) } \\
\text { Pechea }\end{array}$ & B & $\mathbf{C}$ & & Dimensiuni: diam. 65 m, h. 7 m. & $\begin{array}{l}\text { Se situează pe interfluviul } \\
\text { dintre văile Gerului și } \\
\text { Cocorașului. }\end{array}$ & $\begin{array}{l}\text { Brudiu 1991, 48; } \\
\text { Brudiu 2003, 101, nr. } \\
80 .\end{array}$ \\
\hline
\end{tabular}




\begin{tabular}{|c|c|c|c|c|c|c|c|c|c|}
\hline $\begin{array}{l}\text { Nr. } \\
\text { crt. }\end{array}$ & Toponim & Administrativ & B & $\mathbf{C}$ & $\mathbf{F}$ & $\mathbf{T}$ & Descriere & Localizare & Bibliografie \\
\hline
\end{tabular}

\begin{tabular}{|c|c|c|c|c|c|c|c|c|}
\hline 50 & Neprecizat & $\begin{array}{l}\text { Pechea (com.), } \\
\text { Pechea }\end{array}$ & B & & & Dimensiuni: diam. 40 m, h. 1,50 m. & $\begin{array}{l}\text { Pe teritoriul fostului IAS } \\
\text { Ivești, la } 150 \text { m sud de } \\
\text { Movila Potârnichea (nr. 80). }\end{array}$ & $\begin{array}{l}\text { Brudiu 2003, 122, nr. } \\
311\end{array}$ \\
\hline 51 & Neprecizat & $\begin{array}{l}\text { Pechea (com.), } \\
\text { Pechea }\end{array}$ & B & & & Dimensiuni: diam. 35 m, h. 1 m. & $\begin{array}{l}\text { Pe teritoriul fostului IAS } \\
\text { Ivești, la } 300 \text { m sud de } \\
\text { Movila Potârnichea (nr. 80). }\end{array}$ & $\begin{array}{l}\text { Brudiu 2003, 123, nr. } \\
312\end{array}$ \\
\hline 52 & Neprecizat & $\begin{array}{l}\text { Pechea (com.) } \\
\text { Pechea }\end{array}$ & B & & & Dimensiuni: diam. 25 m, h. 1 m. & $\begin{array}{l}\text { Se află la } 1 \mathrm{~km} \text { sud de } \\
\text { Movila Potârnichea (nr. 49). }\end{array}$ & $\begin{array}{l}\text { Brudiu 1991, 48; } \\
\text { Brudiu 2003, 101, nr. } \\
81 .\end{array}$ \\
\hline 53 & $\begin{array}{l}\text { Movila lui } \\
\text { Șerban }\end{array}$ & $\begin{array}{l}\text { Pechea (com.), } \\
\text { Pechea }\end{array}$ & & $\mathbf{C}$ & $\mathbf{F}$ & - & $\begin{array}{l}\text { La extremitatea nordică a } \\
\text { dealului Cocorașului. }\end{array}$ & 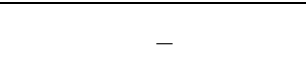 \\
\hline 54 & Neprecizat & $\begin{array}{c}\text { Slobozia Conachi } \\
\text { (com.), Slobozia } \\
\text { Conachi }\end{array}$ & B & & $\mathbf{F}$ & Dimensiuni: diam. $30 \mathrm{~m}$, h. 1,50 m. & $\begin{array}{l}\text { La marginea vestică a } \\
\text { interfluviului dintre văile } \\
\text { Gerului și Cocorașului. }\end{array}$ & $\begin{array}{l}\text { Brudiu 1991, 48; } \\
\text { Brudiu 2003, 102, nr. } \\
90 .\end{array}$ \\
\hline 55 & $\begin{array}{l}\text { Movila din } \\
\text { Şosea }\end{array}$ & $\begin{array}{l}\text { Pechea (com.) } \\
\text { Pechea }\end{array}$ & B & $\mathbf{C}$ & & Dimensiuni: diam. 40 m, h. 1,50 m. & $\begin{array}{l}\text { Pe dealul Vulpi, adiacentă } \\
\text { şoselei Pechea-Costache } \\
\text { Negri. }\end{array}$ & $\begin{array}{l}\text { Brudiu 1991, 50; } \\
\text { Brudiu 2003, 108, nr. } \\
155 .\end{array}$ \\
\hline 56 & $\begin{array}{l}\text { Movila } \\
\text { Gemenea }\end{array}$ & $\begin{array}{l}\text { Pechea (com.) } \\
\text { Pechea }\end{array}$ & B & $\mathbf{C}$ & & Dimensiuni: diam. 50 m, h. 2 m. & $\begin{array}{l}\text { Pe dealul Gemenea, situat la } \\
\text { nord vest de Pechea spre } \\
\text { hotarul cu Costache Negri. }\end{array}$ & $\begin{array}{l}\text { Brudiu 1991, 51; } \\
\text { Brudiu 2003, 109, nr. } \\
157 .\end{array}$ \\
\hline 57 & $\begin{array}{l}\text { Movila } \\
\text { Cetățuia } \\
\text { (Movila } \\
\text { Pechea) } \\
\end{array}$ & $\begin{array}{l}\text { Pechea (com.) } \\
\text { Pechea }\end{array}$ & B & $\mathbf{C}$ & & Dimensiuni: diam. 35 m, h. 1 m. & $\begin{array}{l}\text { La nord de comună și la } \\
\text { vest de drumul ce duce la } \\
\text { Lupele. }\end{array}$ & $\begin{array}{l}\text { Brudiu 1991, 50; } \\
\text { Brudiu 2003, 108-109, } \\
\text { nr. } 156 .\end{array}$ \\
\hline 58 & Neprecizat & $\begin{array}{l}\text { Slobozia Conachi } \\
\text { (com.), Slobozia } \\
\text { Conachi }\end{array}$ & B & & & Dimensiuni: diam. 50 m, h. 3 m. & $\begin{array}{l}\text { Pe interfluviul dintre văile } \\
\text { Gerului și Cocoraşului, la } \\
2,20 \text { km vest de Movila } \\
\text { Ciuperca (nr. 60). }\end{array}$ & $\begin{array}{l}\text { Brudiu 1991, 48; } \\
\text { Brudiu 2003, 103, nr. } \\
98 .\end{array}$ \\
\hline 59 & Neprecizat & $\begin{array}{l}\text { Slobozia Conachi } \\
\text { (com.), Slobozia } \\
\text { Conachi }\end{array}$ & B & $\mathbf{C}$ & & Dimensiuni: diam. 60 m, h. 5 m. & $\begin{array}{l}\text { Pe interfluviul dintre văile } \\
\text { Gerului și Cocorașului, în } \\
\text { apropierea nr. } 58 \text {. }\end{array}$ & $\begin{array}{l}\text { Brudiu 1991, 48; } \\
\text { Brudiu 2003, 103, nr. } \\
99 .\end{array}$ \\
\hline 60 & $\begin{array}{l}\text { Movila } \\
\text { Ciuperca }\end{array}$ & $\begin{array}{c}\text { Slobozia Conachi } \\
\text { (com.), Slobozia } \\
\text { Conachi }\end{array}$ & B & $\mathbf{C}$ & & Dimensiuni: diam. 40 m, h. 2 m. & $\begin{array}{l}\text { La est de Valea } \\
\text { Cocorașului. }\end{array}$ & $\begin{array}{l}\text { Brudiu 1991, 48; } \\
\text { Brudiu 2003, 103, nr. } \\
100 .\end{array}$ \\
\hline 61 & $\begin{array}{c}\text { Movila } \\
\text { Bucur (sau } \\
\text { Odae la } \\
\text { Stejar) } \\
\end{array}$ & $\begin{array}{l}\text { Slobozia Conachi } \\
\text { (com.), Slobozia } \\
\text { Conachi }\end{array}$ & B & $\mathbf{C}$ & & Dimensiuni: diam. 45 m, h. 2 m. & $\begin{array}{l}\text { La } 1,50 \mathrm{~km} \text { sud de Movila } \\
\text { Ciuperca. }\end{array}$ & $\begin{array}{l}\text { Brudiu 1991, 48; } \\
\text { Brudiu 2003, 103, nr. } \\
101 .\end{array}$ \\
\hline 62 & Neprecizat & $\begin{array}{l}\text { Slobozia Conachi } \\
\text { (com.), Slobozia } \\
\text { Conachi }\end{array}$ & B & & & Dimensiuni: diam. 50 m, h. 3 m. & $\begin{array}{l}\text { Lângă o viroagă de pe } \\
\text { latura vestică a } \\
\text { interfluviului dintre văile } \\
\text { Gerului și Suhurlui, la } 500 \\
\text { m sud de movila nr. } 99 .\end{array}$ & $\begin{array}{l}\text { Brudiu 1991, 48; } \\
\text { Brudiu 2003, 103, nr. } \\
102 .\end{array}$ \\
\hline
\end{tabular}




\begin{tabular}{|c|c|c|c|c|c|c|c|c|c|}
\hline $\begin{array}{l}\text { Nr. } \\
\text { crt. }\end{array}$ & Toponim & Administrativ & B & $\mathbf{C}$ & $\mathbf{F}$ & $\mathbf{T}$ & Descriere & Localizare & Bibliografie \\
\hline
\end{tabular}

\begin{tabular}{|c|c|c|c|c|c|c|c|c|}
\hline 63 & $\begin{array}{l}\text { Movila } \\
\text { Copoiu }\end{array}$ & $\begin{array}{c}\text { Slobozia Conachi } \\
\text { (com.), Slobozia } \\
\text { Conachi }\end{array}$ & B & $\mathbf{C}$ & & Dimensiuni: diam. 35 m, h. 1,50 m. & $\begin{array}{l}\text { Pe interfluviul dintre o } \\
\text { viroagă și Valea Gerului. }\end{array}$ & $\begin{array}{l}\text { Brudiu 1991, 49; } \\
\text { Brudiu 2003, 104, nr. } \\
106 .\end{array}$ \\
\hline 64 & Neprecizat & $\begin{array}{l}\text { Slobozia Conachi } \\
\text { (com.), sat } \\
\text { Izvoarele }\end{array}$ & B & & $\mathbf{F}$ & Dimensiuni: diam. $30 \mathrm{~m}$, h. 1,50 m. & $\begin{array}{l}\text { La est de localitate, pe } \\
\text { dealul La Izvoare, la } 100 \mathrm{~m} \\
\text { nord de nr. } 66 .\end{array}$ & $\begin{array}{l}\text { Brudiu 1991, 51, nr. } \\
\text { 171; Brudiu 2003, 110, } \\
\text { nr. } 171 .\end{array}$ \\
\hline 65 & Neprecizat & $\begin{array}{l}\text { Slobozia Conachi } \\
\text { (com.), sat } \\
\text { Izvoarele }\end{array}$ & & $\mathbf{C}$ & $\mathbf{F}$ & - & $\begin{array}{l}\text { La est de localitate, pe } \\
\text { dealul La Izvoare, la } 700 \mathrm{~m} \\
\text { nord de nr. } 64 .\end{array}$ & - \\
\hline 66 & Neprecizat & $\begin{array}{l}\text { Slobozia Conachi } \\
\text { (com.), sat } \\
\text { Izvoarele }\end{array}$ & B & $\mathbf{C}$ & $\mathbf{F}$ & Dimensiuni: diam. 25 m, h. 1 m. & $\begin{array}{l}\text { Pe ultima curbă ne nivel, la } \\
600 \text { m est de satul } \\
\text { Izvoarele. }\end{array}$ & $\begin{array}{l}\text { Brudiu 1991, 51, nr. } \\
\text { 172; Brudiu 2003, 110, } \\
\text { nr. } 172 .\end{array}$ \\
\hline 67 & Neprecizat & $\begin{array}{c}\text { Slobozia Conachi } \\
\text { (com.), Slobozia } \\
\text { Conachi }\end{array}$ & B & & & Dimensiuni: diam. 25 m, h. 1 m. & $\begin{array}{l}\text { Lângă şoseaua Galați- } \\
\text { Tecuci, la } 300 \text { m est de nr. } \\
68 .\end{array}$ & $\begin{array}{l}\text { Brudiu 1991, 51; } \\
\text { Brudiu 2003, 110, nr. } \\
168 .\end{array}$ \\
\hline 68 & $\begin{array}{l}\text { Movila } \\
\text { Săpată }\end{array}$ & $\begin{array}{c}\text { Slobozia Conachi } \\
\text { (com.), Slobozia } \\
\text { Conachi }\end{array}$ & B & & & Dimensiuni: diam. 35 m, h. 1,50 m. & $\begin{array}{l}\text { Lângă şoseaua Galați- } \\
\text { Tecuci, la } 1 \text { km nord de nr. } \\
69 .\end{array}$ & $\begin{array}{l}\text { Brudiu 1991, 51; } \\
\text { Brudiu 2003, 110, nr. } \\
167 .\end{array}$ \\
\hline 69 & Neprecizat & $\begin{array}{l}\text { Slobozia Conachi } \\
\text { (com.), Slobozia } \\
\text { Conachi }\end{array}$ & B & & & Dimensiuni: diam. 25 m, h. 1 m. & $\begin{array}{l}\text { La } 500 \text { m vest de șoseaua } \\
\text { Galați-Tecuci și cca } 3,70 \\
\text { km nord de Movila Popii } \\
\text { (nr. 105). }\end{array}$ & $\begin{array}{l}\text { Brudiu 1991, 51; } \\
\text { Brudiu 2003, 110, nr. } \\
169 .\end{array}$ \\
\hline 70 & $\begin{array}{l}\text { Movila } \\
\text { Copoiul }\end{array}$ & $\begin{array}{l}\text { Piscu (com.), sat } \\
\text { Piscu }\end{array}$ & B & $\mathbf{C}$ & & Dimensiuni: diam. 50 m, h. 2 m. & $\begin{array}{l}\text { La confluența văilor } \\
\text { Gerului cu Copoiu, la 2,80 } \\
\text { km nord-vest de Movila lui } \\
\text { Pușcoi (nr. 71). }\end{array}$ & $\begin{array}{l}\text { Brudiu 1991, 49, nr. } \\
\text { 114; Brudiu 2003, 104, } \\
\text { nr. } 114 .\end{array}$ \\
\hline 71 & $\begin{array}{l}\text { Movila lui } \\
\text { Pușcoi }\end{array}$ & $\begin{array}{l}\text { Piscu (com.), sat } \\
\text { Piscu }\end{array}$ & B & $\mathbf{C}$ & & Dimensiuni: diam. 70 m, h. 4 m. & $\begin{array}{l}\text { Pe dealul Copoiului, la sud } \\
\text { de drumul Slobozia } \\
\text { Conachi-Valea Gerului, la } \\
7,50 \mathrm{~km} \text { nord de satul } \\
\text { Vameș. }\end{array}$ & $\begin{array}{l}\text { Brudiu 1991, 49, nr. } \\
\text { 115; Brudiu 2003, 104, } \\
\text { nr. } 115 .\end{array}$ \\
\hline 72 & Neprecizat & $\begin{array}{l}\text { Piscu (com.), sat } \\
\text { Piscu }\end{array}$ & $\mathbf{B}$ & $\mathbf{C}$ & & Dimensiuni: diam. 50 m, h. 3 m. & $\begin{array}{l}\text { La } 1 \mathrm{~km} \text { est de Valea } \\
\text { Gerului și la } 6 \mathrm{~km} \text { nord de } \\
\text { satul Vameș. }\end{array}$ & $\begin{array}{l}\text { Brudiu 1991, 51, nr. } \\
\text { 174; Brudiu 2003, 110, } \\
\text { nr. } 174 .\end{array}$ \\
\hline 73 & Neprecizat & $\begin{array}{l}\text { Piscu (com.), sat } \\
\text { Piscu }\end{array}$ & B & $\mathbf{C}$ & $\mathbf{F}$ & Dimensiuni: diam. 25 m, h. 1 m. & $\begin{array}{l}\text { Pe dealul „Patru Tumuli”, la } \\
1,70 \mathrm{~km} \text { sud de nr. } 71 .\end{array}$ & $\begin{array}{l}\text { Brudiu 1991, 50, nr. } \\
\text { 133; Brudiu 2003, 106, } \\
\text { nr. } 133 .\end{array}$ \\
\hline 74 & Neprecizat & $\begin{array}{l}\text { Piscu (com.), sat } \\
\text { Piscu }\end{array}$ & B & $\mathbf{C}$ & $\mathbf{F}$ & Dimensiuni: diam. 30 m, h. 1 m. & $\begin{array}{l}\text { Pe dealul „Patru Tumuli”, la } \\
175 \text { m sud de nr. } 73 \text {. }\end{array}$ & $\begin{array}{l}\text { Brudiu 1991, 49, nr. } \\
\text { 126; Brudiu 2003, 105- } \\
\text { 106, nr. } 126 .\end{array}$ \\
\hline 75 & Neprecizat & $\begin{array}{l}\text { Piscu (com.), sat } \\
\text { Piscu }\end{array}$ & B & $\mathbf{C}$ & $\mathbf{F}$ & Dimensiuni: diam. 25 m, h. 1 m. & $\begin{array}{l}\text { Pe dealul „Patru Tumuli”, la } \\
100 \text { m sud de nr. } 74 .\end{array}$ & $\begin{array}{l}\text { Brudiu 1991, 50, nr. } \\
\text { 132; Brudiu 2003, 106, } \\
\text { nr. } 132 .\end{array}$ \\
\hline
\end{tabular}




\begin{tabular}{|c|c|c|c|c|c|c|c|c|c|}
\hline $\begin{array}{l}\text { Nr. } \\
\text { crt. }\end{array}$ & Toponim & Administrativ & B & C & $\mathbf{F}$ & $\mathbf{T}$ & Descriere & Localizare & Bibliografie \\
\hline
\end{tabular}

\begin{tabular}{|c|c|c|c|c|c|c|c|c|}
\hline 76 & $\begin{array}{c}\text { Patru } \\
\text { Tumuli } 4\end{array}$ & $\begin{array}{l}\text { Piscu (com.), sat } \\
\text { Piscu }\end{array}$ & $\mathbf{B}$ & $\mathbf{C}$ & $\mathbf{F}$ & $\begin{array}{l}\text { Face parte dintr-un grup de patru tumuli și are dimensiunile de diam. } 60 \\
\text { m, h. } 4 \text { m. }\end{array}$ & $\begin{array}{l}\text { Pe dealul „Patru Tumuli”, la } \\
\text { cca } 4 \mathrm{~km} \text { nord de sat (a } \\
\text { patra din grup) }\end{array}$ & $\begin{array}{l}\text { Brudiu 2003, 132, nr. } \\
407 .\end{array}$ \\
\hline 77 & $\begin{array}{c}\text { Patru } \\
\text { Tumuli } 3\end{array}$ & $\begin{array}{l}\text { Piscu (com.), sat } \\
\text { Piscu }\end{array}$ & $\mathbf{B}$ & $\mathbf{C}$ & $\mathbf{F}$ & $\begin{array}{l}\text { Face parte dintr-un grup de patru tumuli și are dimensiunile de diam. } 20 \\
\text { m, h. } 2 \text { m. }\end{array}$ & $\begin{array}{l}\text { Pe dealul „Patru Tumuli”, la } \\
\text { cca } 4 \mathrm{~km} \text { nord de sat (a treia } \\
\text { din grup) }\end{array}$ & $\begin{array}{l}\text { Brudiu 2003, 132, nr. } \\
406 .\end{array}$ \\
\hline 78 & $\begin{array}{c}\text { Patru } \\
\text { Tumuli } 2\end{array}$ & $\begin{array}{l}\text { Piscu (com.), sat } \\
\text { Piscu }\end{array}$ & $\mathbf{B}$ & $\mathbf{C}$ & $\mathbf{F}$ & $\begin{array}{l}\text { Face parte dintr-un grup de patru tumuli şi are dimensiunile de diam. } 40 \\
\text { m, h. } 2 \text { m. }\end{array}$ & $\begin{array}{l}\text { Pe dealul „Patru Tumuli”, la } \\
\text { cca } 4 \mathrm{~km} \text { nord de sat (a } \\
\text { doua din grup) }\end{array}$ & $\begin{array}{l}\text { Brudiu 2003, 132, nr. } \\
405 .\end{array}$ \\
\hline 79 & $\begin{array}{l}\text { Patru } \\
\text { Tumuli } 1\end{array}$ & $\begin{array}{l}\text { Piscu (com.), sat } \\
\text { Piscu }\end{array}$ & $\mathbf{B}$ & $\mathbf{C}$ & $\mathbf{F}$ & $\begin{array}{l}\text { Face parte dintr-un grup de patru tumuli şi are dimensiunile de diam. } 40- \\
60 \mathrm{~m} \text {, h. } 2-4 \mathrm{~m} \text {. }\end{array}$ & $\begin{array}{l}\text { Pe dealul „Patru Tumuli”, la } \\
\text { cca } 4 \mathrm{~km} \text { nord de sat (prima } \\
\text { din grup). }\end{array}$ & $\begin{array}{l}\text { Brudiu 1991, 49, nr. } \\
\text { 127; Brudiu 2003, 106, } \\
\text { nr. } 127 .\end{array}$ \\
\hline 80 & Neprecizat & $\begin{array}{l}\text { Piscu (com.), sat } \\
\text { Vameș }\end{array}$ & & $\mathbf{C}$ & $\mathbf{F}$ & - & $\begin{array}{l}\text { La } 1,65 \mathrm{~km} \text { est de satul } \\
\text { Vameș. }\end{array}$ & 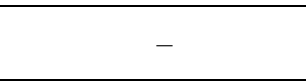 \\
\hline 81 & Movila Niță & $\begin{array}{l}\text { Piscu (com.), sat } \\
\text { Vameș }\end{array}$ & & $\mathbf{C}$ & $\mathbf{F}$ & - & $\begin{array}{l}\text { La 1,60 km est de satul } \\
\text { Vameș, lângă nr. } 80 .\end{array}$ & - \\
\hline 82 & Neprecizat & $\begin{array}{l}\text { Piscu (com.), sat } \\
\text { Vameș }\end{array}$ & & $\mathbf{C}$ & $\mathbf{F}$ & - & $\begin{array}{l}\text { La } 800 \text { m est de biserica din } \\
\text { Vameș. }\end{array}$ & - \\
\hline 83 & Neprecizat & $\begin{array}{l}\text { Piscu (com.), sat } \\
\text { Vameș }\end{array}$ & & $\mathbf{C}$ & $\mathbf{F}$ & - & La 700 m sud de nr. 81. & - \\
\hline 84 & Neprecizat & $\begin{array}{l}\text { Piscu (com.), sat } \\
\text { Vameș }\end{array}$ & & $\mathbf{C}$ & $\mathbf{F}$ & - & La 380 m sud-est de nr. 83 . & - \\
\hline 85 & Neprecizat & $\begin{array}{l}\text { Piscu (com.), sat } \\
\text { Vameș }\end{array}$ & & $\mathbf{C}$ & $\mathbf{F}$ & - & $\begin{array}{l}\text { La } 800 \text { m sud-est de Vameș } \\
\text { și la } 400 \text { m est de calea } \\
\text { ferată. }\end{array}$ & - \\
\hline 86 & Neprecizat & $\begin{array}{l}\text { Piscu (com.), sat } \\
\text { Vameș }\end{array}$ & & $\mathbf{C}$ & $\mathbf{F}$ & - & $\begin{array}{l}\text { La } 400 \text { m sud de nr. } 85 \text { şi } \\
330 \text { m est de calea ferată. }\end{array}$ & - \\
\hline 87 & Neprecizat & $\begin{array}{l}\text { Piscu (com.), sat } \\
\text { Vameș }\end{array}$ & & $\mathbf{C}$ & $\mathbf{F}$ & - & La $150 \mathrm{~m}$ sud de nr. 86. & - \\
\hline 88 & Neprecizat & $\begin{array}{l}\text { Piscu (com.), sat } \\
\text { Piscu }\end{array}$ & & $\mathbf{C}$ & $\mathbf{F}$ & Dimensiuni: diam. 50 m, h. 4 m. & $\begin{array}{l}\text { Între Piscu și Vameș, la est } \\
\text { de calea ferată Galați- } \\
\text { Tecuci. }\end{array}$ & $\begin{array}{l}\text { Brudiu 1991, 49, nr. } \\
\text { 131; Brudiu 2003, 106, } \\
\text { nr. } 131 .\end{array}$ \\
\hline 89 & Neprecizat & $\begin{array}{l}\text { Piscu (com.), sat } \\
\text { Piscu }\end{array}$ & & $\mathbf{C}$ & $\mathbf{F}$ & - & $\begin{array}{l}\text { Pe extremitatea sudică a } \\
\text { Dealului Cristești, lângă nr. } \\
\text { 90. }\end{array}$ & - \\
\hline 90 & Neprecizat & $\begin{array}{l}\text { Piscu (com.), sat } \\
\text { Piscu }\end{array}$ & & $\mathbf{C}$ & $\mathbf{F}$ & - & $\begin{array}{l}\text { Pe extremitatea sudică a } \\
\text { Dealului Cristești, lângă nr. } \\
\text { 89. }\end{array}$ & - \\
\hline 91 & $\begin{array}{l}\text { Movila } \\
\text { Săpată }\end{array}$ & $\begin{array}{l}\text { Piscu (com.), sat } \\
\text { Piscu }\end{array}$ & B & $\mathbf{C}$ & $\mathbf{F}$ & Dimensiuni: diam. 35 m, h. 1 m. & $\begin{array}{l}\text { În zona sudică a } \\
\text { interfluviului dintre valea } \\
\text { Geru și valea Suhurlui, la } \\
2,50 \mathrm{~km} \text { nord de sat. } \\
\end{array}$ & $\begin{array}{l}\text { Brudiu 1991, 49, nr. } \\
\text { 129; Brudiu 2003, 106, } \\
\text { nr. } 129 .\end{array}$ \\
\hline
\end{tabular}




\begin{tabular}{|l|l|l|l|l|l|l|l|l|l|}
\hline $\begin{array}{c}\text { Nr. } \\
\text { crt. }\end{array}$ & Toponim & Administrativ & B & C & F & T & Descriere & Localizare & Bibliografie \\
\hline
\end{tabular}

\begin{tabular}{|c|c|c|c|c|c|c|c|c|}
\hline 92 & $\begin{array}{l}\text { Movila } \\
\text { Piscul }\end{array}$ & $\begin{array}{l}\text { Piscu (com.), sat } \\
\text { Piscu }\end{array}$ & $\mathbf{B}$ & C & & Dimensiuni: diam. 40 m, h. 2 m. & $\begin{array}{l}\text { Marginea nordică a } \\
\text { localitătaii. Actualmente în } \\
\text { interiorul localității. }\end{array}$ & $\begin{array}{l}\text { Brudiu 1991, 49, nr. } \\
\text { 130; Brudiu 2003, 106, } \\
\text { nr. } 130 .\end{array}$ \\
\hline 93 & Neprecizat & $\begin{array}{l}\text { Piscu (com.), sat } \\
\text { Piscu }\end{array}$ & B & C & $\mathbf{F}$ & Dimensiuni: diam. 50 m, h. 2,50 m. & $\begin{array}{l}\text { Localizarea se notează: „pe } \\
\text { cumpăna apelor, pe dealul } \\
\text { Plopului, pe drumul } \\
\text { Galatilor”. }\end{array}$ & $\begin{array}{l}\text { Brudiu 1991, 50, nr. } \\
\text { 135; Brudiu 2003, 106, } \\
\text { nr. } 135 .\end{array}$ \\
\hline 94 & Neprecizat & $\begin{array}{c}\text { Piscu (com.), sat } \\
\text { Piscu }\end{array}$ & $\mathbf{B}$ & & $\mathbf{F}$ & Dimensiuni: diam. 60 m, h. 3 m. & $\begin{array}{l}\text { La est de localitate, în } \\
\text { marginea de vest a şesului } \\
\text { Suhurluiului, la } 300 \mathrm{~m} \text { nord } \\
\text { de calea ferată Galați- } \\
\text { Tecuci. }\end{array}$ & $\begin{array}{l}\text { Brudiu 1991, 51, nr. } \\
\text { 165; Brudiu 2003, 109, } \\
\text { nr. } 165 .\end{array}$ \\
\hline 95 & Neprecizat & $\begin{array}{l}\text { Piscu (com.), sat } \\
\text { Piscu }\end{array}$ & & C & $\mathbf{F}$ & - & $\begin{array}{l}\text { Pe versantul estic al Văii } \\
\text { Suhurluiului, la } 1,40 \mathrm{~km} \\
\text { sud-vest de Movila } \\
\text { Gemenei Independenței. }\end{array}$ & - \\
\hline 96 & Neprecizat & $\begin{array}{l}\text { Piscu (com.), sat } \\
\text { Piscu }\end{array}$ & & & $\mathbf{F}$ & - & $\begin{array}{l}\text { La } 700 \mathrm{~m} \text { sud de Valea } \\
\text { Tarinei şi la 1,70 km nord } \\
\text { de Movila Săpată. }\end{array}$ & - \\
\hline 97 & Neprecizat & $\begin{array}{l}\text { Piscu (com.), sat } \\
\text { Piscu }\end{array}$ & & $\mathrm{C}$ & $\mathbf{F}$ & - & $\begin{array}{l}\mathrm{La} 2 \mathrm{~km} \text { vest de Valea } \\
\text { Suhurluiului și la 2,50 km } \\
\text { nord-est de Movila Săpată. }\end{array}$ & - \\
\hline 98 & Neprecizat & $\begin{array}{l}\text { Independența } \\
\text { (com.), sat } \\
\text { Independența }\end{array}$ & & C & $\mathbf{F}$ & - & $\begin{array}{l}\text { La hotarul dintre comunele } \\
\text { Piscu și Independenta, în } \\
\text { apropiere de Piscu, la } 500 \mathrm{~m} \\
\text { sud de calea ferată. La } 1 \mathrm{~km} \\
\text { nord de Movila Chirilă- } \\
\text { Stan. }\end{array}$ & - \\
\hline 99 & Neprecizat & $\begin{array}{l}\text { Independența } \\
\text { (com.), sat } \\
\text { Independența }\end{array}$ & & C & $\mathbf{F}$ & - & $\begin{array}{l}\text { La } 1,20 \mathrm{~km} \text { est de ieșirea } \\
\text { din satul Piscul, la } 150 \mathrm{~m} \\
\text { nord de soseaua ce duce la } \\
\text { Independența. }\end{array}$ & - \\
\hline 100 & Neprecizat & $\begin{array}{l}\text { Independența } \\
\text { (com.), sat } \\
\text { Independența }\end{array}$ & & $\mathrm{C}$ & $\mathbf{F}$ & - & $\begin{array}{l}\text { La } 800 \mathrm{~m} \text { est de Movila } \\
\text { Chirilă Stan si la } 400 \mathrm{~m} \text { vest } \\
\text { de trecerea la nivel cu calea } \\
\text { ferată. }\end{array}$ & - \\
\hline 101 & Neprecizat & $\begin{array}{l}\text { Independența } \\
\text { (com.), sat } \\
\text { Independența }\end{array}$ & & C & $\mathbf{F}$ & - & $\begin{array}{l}\text { La } 1 \mathrm{~km} \text { sud-est de Movila } \\
\text { Chirilă Stan și la } 300 \mathrm{~m} \\
\text { nord de șoseaua ce duce la } \\
\text { Independența. }\end{array}$ & - \\
\hline
\end{tabular}




\begin{tabular}{|l|l|l|l|l|l|l|l|c|c|}
\hline $\begin{array}{l}\text { Nr. } \\
\text { crt. }\end{array}$ & Toponim & Administrativ & B & C & F & T & Descriere & Localizare & Bibliografie \\
\hline
\end{tabular}

\begin{tabular}{|c|c|c|c|c|c|c|c|c|}
\hline 102 & Neprecizat & $\begin{array}{l}\text { Independența } \\
\text { (com.), sat } \\
\text { Independența }\end{array}$ & $\mathbf{B}$ & $\mathbf{C}$ & $\mathbf{F}$ & Dimensiuni: diam. 45 m, h. 2 m. & $\begin{array}{l}\text { Pe interfluviul Gemeni, } \\
\text { format între valea Suhurlui } \\
\text { și valea Catina. La } 1 \mathrm{~km} \\
\text { nord de intrarea în sat și la } \\
400 \mathrm{~m} \text { est de drumul } \\
\text { Independența-Izvoarele. }\end{array}$ & $\begin{array}{l}\text { Brudiu 1991, 51, nr. } \\
\text { 175; Brudiu 2003, 110, } \\
\text { nr. } 175 .\end{array}$ \\
\hline 103 & $\begin{array}{l}\text { Movila } \\
\text { Gemeni (M-la } \\
\text { Gemenei } \\
\text { Independentẹi) }\end{array}$ & $\begin{array}{l}\text { Independența } \\
\text { (com.), sat } \\
\text { Independența }\end{array}$ & $\mathbf{B}$ & $\mathbf{C}$ & $\mathbf{F}$ & Dimensiuni: diam. 45 m, h. 3 m. & Situată pe dealul omonim. & $\begin{array}{l}\text { Brudiu 1991, 51, nr. } \\
\text { 173; Brudiu 2003, 110, } \\
\text { nr. } 173 .\end{array}$ \\
\hline 104 & Neprecizat & $\begin{array}{l}\text { Independența } \\
\text { (com.), sat } \\
\text { Independența }\end{array}$ & $\mathbf{B}$ & $\mathbf{C}$ & $\mathbf{F}$ & Dimensiuni: diam. 40 m, h. 2 m. & $\begin{array}{l}\text { Pe interfluviul de la vest de } \\
\text { valea Topârneaga. }\end{array}$ & $\begin{array}{l}\text { Brudiu 1991, 51, nr. } \\
\text { 179; Brudiu 2003, 111, } \\
\text { nr. } 179 .\end{array}$ \\
\hline 105 & $\begin{array}{l}\text { MovilaPopii } \\
\text { (sau M-la cu } \\
\text { Piatră) }\end{array}$ & $\begin{array}{l}\text { Independența } \\
\text { (com.), sat } \\
\text { Independența }\end{array}$ & $\mathbf{B}$ & $\mathbf{C}$ & $\mathbf{F}$ & Dimensiuni: diam. 55 m, h. 3 m. & $\begin{array}{l}\text { Pe interfluviul de la vest de } \\
\text { valea Topârneaga. La 2,50 } \\
\text { km nord-vest de satul } \\
\text { Lascăr Catargiu. }\end{array}$ & $\begin{array}{l}\text { Brudiu 1991, 51, nr. } \\
\text { 181; Brudiu 2003, 111, } \\
\text { nr. } 181 .\end{array}$ \\
\hline 106 & Neprecizat & $\begin{array}{l}\text { Independența } \\
\text { (com.), sat } \\
\text { Independența }\end{array}$ & $\mathbf{B}$ & $\mathbf{C}$ & $\mathbf{F}$ & Dimensiuni: diam. 30 m, h. 1 m. & $\begin{array}{l}\text { Pe dealul Movila Gemenei, } \\
\text { la } 1,50 \mathrm{~km} \text { sud de movila } \\
\text { eponimă (nr. 103) }\end{array}$ & $\begin{array}{l}\text { Brudiu 1991, 49, nr. } \\
\text { 183; Brudiu 2003, 111, } \\
\text { nr. } 183 \text {. }\end{array}$ \\
\hline 107 & Neprecizat & $\begin{array}{l}\text { Independența } \\
\text { (com.), sat } \\
\text { Independența }\end{array}$ & & & $\mathbf{F}$ & - & $\begin{array}{l}\text { Pe dealul Movila Gemenei, } \\
\text { la } 1,80 \mathrm{~km} \text { sud de movila } \\
\text { eponimă (nr. 103) }\end{array}$ & 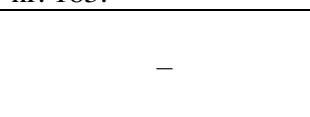 \\
\hline 108 & Neprecizat & $\begin{array}{l}\text { Independența } \\
\text { (com.), sat } \\
\text { Independența }\end{array}$ & B & $\mathrm{C}$ & $\mathbf{F}$ & Dimensiuni: diam. 40 m, h. 2 m. & $\begin{array}{l}\text { Pe dealul Movila Gemenei, } \\
\text { la } 80 \text { m sud-est de nr. } 107 .\end{array}$ & $\begin{array}{l}\text { Brudiu 1991, 51, nr. } \\
\text { 178; Brudiu 2003, 111, } \\
\text { nr. } 178 .\end{array}$ \\
\hline 109 & Neprecizat & $\begin{array}{l}\text { Independența } \\
\text { (com.), sat } \\
\text { Independența }\end{array}$ & & & $\mathbf{F}$ & - & $\begin{array}{l}\text { Pe dealul Movila Gemenei, } \\
\text { la } 360 \mathrm{~m} \text { est de nr. } 108 .\end{array}$ & 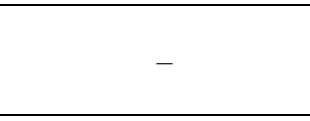 \\
\hline 110 & Neprecizat & $\begin{array}{l}\text { Independența } \\
\text { (com.), sat } \\
\text { Independența }\end{array}$ & & & $\mathbf{F}$ & - & $\begin{array}{l}\text { Pe dealul Movila Gemenei, } \\
\text { la } 200 \mathrm{~m} \text { sud de nr. } 108 .\end{array}$ & - \\
\hline 111 & Neprecizat & $\begin{array}{l}\text { Independența } \\
\text { (com.), sat } \\
\text { Independența }\end{array}$ & & & $\mathbf{F}$ & - & $\begin{array}{l}\text { Pe dealul Movila Gemenei, } \\
\text { la } 300 \mathrm{~m} \text { sud de nr. } 108 .\end{array}$ & - \\
\hline 112 & Neprecizat & $\begin{array}{l}\text { Independența } \\
\text { (com.), sat } \\
\text { Independența }\end{array}$ & & & $\mathbf{F}$ & - & $\begin{array}{l}\text { Pe un interfluviu cuprins } \\
\text { între valea Căcainei și valea } \\
\text { Cătinei. La } 1,30 \mathrm{~km} \text { est de } \\
\text { nr. } 108 .\end{array}$ & - \\
\hline 113 & Neprecizat & $\begin{array}{l}\text { Independența } \\
\text { (com.), sat } \\
\text { Independența }\end{array}$ & & & $\mathbf{F}$ & - & $\begin{array}{l}\text { Pe un interfluviu cuprins } \\
\text { între valea Căcainei și valea } \\
\text { Cătinei. La } 100 \mathrm{~m} \text { sud de nr. } \\
112 .\end{array}$ & - \\
\hline
\end{tabular}




\begin{tabular}{|c|c|c|c|c|c|c|c|c|c|}
\hline $\begin{array}{l}\text { Nr. } \\
\text { crt. }\end{array}$ & Toponim & Administrativ & B & C & $\mathbf{F}$ & $\mathbf{T}$ & Descriere & Localizare & Bibliografie \\
\hline
\end{tabular}

\begin{tabular}{|c|c|c|c|c|c|c|c|c|c|}
\hline 114 & Neprecizat & $\begin{array}{l}\text { Independența } \\
\text { (com.), sat } \\
\text { Independența }\end{array}$ & $\mathbf{B}$ & $\mathbf{C}$ & $\mathbf{F}$ & & Dimensiuni: diam. 45 m, h. 2 m. & $\begin{array}{l}\text { Pe dealul Movila Gemenei, } \\
\text { la } 1 \mathrm{~km} \text { sud de nr. } 108 .\end{array}$ & $\begin{array}{l}\text { Brudiu 1991, 51, nr. } \\
\text { 178; Brudiu 2003, 111, } \\
\text { nr. } 177 .\end{array}$ \\
\hline 115 & Neprecizat & $\begin{array}{l}\text { Independența } \\
\text { (com.), sat } \\
\text { Independența }\end{array}$ & $\mathbf{B}$ & $\mathbf{C}$ & $\mathbf{F}$ & & Dimensiuni: diam. 40 m, h. 2 m. & $\begin{array}{l}\text { Pe dealul Movila Gemenei, } \\
\text { la } 1,80 \mathrm{~km} \text { sud de nr. } 108 \text {. }\end{array}$ & $\begin{array}{l}\text { Brudiu 1991, 51, nr. } \\
\text { 176; Brudiu 2003, 110, } \\
\text { nr. } 176 .\end{array}$ \\
\hline 116 & Neprecizat & $\begin{array}{l}\text { Independența } \\
\text { (com.), sat } \\
\text { Independența }\end{array}$ & $\mathbf{B}$ & & $\mathbf{F}$ & & Dimensiuni: diam. 25 m, h. 1 m. & $\begin{array}{l}\text { Pe un interfluviu cuprins } \\
\text { între valea Căcainei și valea } \\
\text { Cătinei. La } 400 \text { m sud-est } \\
\text { de nr. } 113 \text {. }\end{array}$ & $\begin{array}{l}\text { Brudiu 1991, 51, nr. } \\
\text { 180; Brudiu 2003, 111, } \\
\text { nr. } 180 \text {. }\end{array}$ \\
\hline 117 & Neprecizat & $\begin{array}{l}\text { Independența } \\
\text { (com.), sat } \\
\text { Independența }\end{array}$ & & $\mathbf{C}$ & $\mathbf{F}$ & & - & $\begin{array}{l}\text { Pe dealul Braina la } 500 \mathrm{~m} \\
\text { nord-est de ieșirea din } \\
\text { localitate. }\end{array}$ & - \\
\hline 118 & Neprecizat & $\begin{array}{l}\text { Independența } \\
\text { (com.), sat } \\
\text { Independența }\end{array}$ & & $\mathbf{C}$ & $\mathbf{F}$ & & - & La 600 m nord de nr. 119. & - \\
\hline 119 & $\begin{array}{l}\text { Movila } \\
\text { Leurda } \\
\text { (Movila } \\
\text { Surdu) }\end{array}$ & $\begin{array}{l}\text { Independența } \\
\text { (com.), sat } \\
\text { Independența }\end{array}$ & $\mathbf{B}$ & $\mathbf{C}$ & $\mathbf{F}$ & & Dimensiuni: diam. 60 m, h. 3 m. & $\begin{array}{l}\text { Pe un deal la est de valea } \\
\text { Căcainei, la } 2,50 \mathrm{~km} \text { nord- } \\
\text { est de localitate. }\end{array}$ & $\begin{array}{l}\text { Brudiu 1991, 52, nr. } \\
\text { 185; Brudiu 2003, 111, } \\
\text { nr. } 185 .\end{array}$ \\
\hline 120 & Neprecizat & $\begin{array}{l}\text { Independența } \\
\text { (com.), sat } \\
\text { Independența }\end{array}$ & & $\mathbf{C}$ & $\mathbf{F}$ & & - & $\begin{array}{l}\text { Pe un deal la est de valea } \\
\text { Căcainei, la } 300 \mathrm{~m} \text { sud de } \\
\text { nr. } 119 .\end{array}$ & - \\
\hline 121 & Neprecizat & $\begin{array}{l}\text { Independența } \\
\text { (com.), sat } \\
\text { Independența }\end{array}$ & & $\mathbf{C}$ & $\mathbf{F}$ & & - & $\begin{array}{l}\text { Pe un deal la est de valea } \\
\text { Căcainei, la } 400 \text { m sud-est } \\
\text { de nr. } 119 .\end{array}$ & - \\
\hline 122 & Neprecizat & $\begin{array}{c}\text { Schela - fostă } \\
\text { Lascăr Catargiu } \\
\text { (com.), sat Negrea }\end{array}$ & $\mathbf{B}$ & & $\mathbf{F}$ & & Dimensiuni: diam. 35 m, h. 2 m. & $\begin{array}{l}\text { La } 5 \mathrm{~km} \text { nord de localitate, } \\
\text { pe dealul Bohotin. }\end{array}$ & $\begin{array}{l}\text { Brudiu 1991, 51, nr. } \\
\text { 164; Brudiu 2003, 109, } \\
\text { nr. } 164 \text {. }\end{array}$ \\
\hline 123 & Neprecizat & $\begin{array}{c}\text { Schela - fostă } \\
\text { Lascăr Catargiu } \\
\text { (com.), sat Schela }\end{array}$ & B & & $\mathbf{F}$ & & Dimensiuni: diam. 30 m, h. 1 m. & $\begin{array}{l}\text { La aproximativ } 1 \mathrm{~km} \text { nord } \\
\text { de şoseaua Galați-Slobozia } \\
\text { Conachi. }\end{array}$ & $\begin{array}{l}\text { Brudiu 1991, 51, nr. } \\
\text { 184; Brudiu 2003, 111, } \\
\text { nr. } 184 \text {. }\end{array}$ \\
\hline 124 & $\begin{array}{l}\text { Movila } \\
\text { Săpată }\end{array}$ & $\begin{array}{l}\text { Schela }- \text { fostă } \\
\text { Lascăr Catargiu } \\
\text { (com.), sat Schela }\end{array}$ & B & $\mathbf{C}$ & $\mathbf{F}$ & & Dimensiuni: diam. 40 m, h. 2 m. & $\begin{array}{l}\text { La sud de șoseaua } \\
\text { Smârdan-Schela }\end{array}$ & $\begin{array}{l}\text { Brudiu 1991, 51, nr. } \\
\text { 182; Brudiu 2003, 111, } \\
\text { nr. } 182 .\end{array}$ \\
\hline 125 & Neprecizat & $\begin{array}{l}\text { Schela - fostă } \\
\text { Lascăr Catargiu } \\
\text { (com.), sat Schela }\end{array}$ & & $\mathbf{C}$ & $\mathbf{F}$ & & - & $\begin{array}{l}\text { În partea de sud-vest a } \\
\text { localității, lângă o casă. }\end{array}$ & 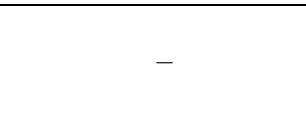 \\
\hline 126 & Neprecizat & $\begin{array}{l}\text { Braniștea (com.), } \\
\text { sat V. Alecsandri }\end{array}$ & & & $\mathbf{F}$ & $\mathbf{T}$ & Face parte dintr-un șir de tumuli situați la vest de valea Lozova. & $\begin{array}{l}\text { La } 2 \mathrm{~km} \text { vest de intrarea în } \\
\text { satul L. Catargiu, dinspre } \\
\text { Braniștea. }\end{array}$ & - \\
\hline
\end{tabular}




\begin{tabular}{|l|l|l|l|l|l|l|l|c|c|}
\hline $\begin{array}{l}\text { Nr. } \\
\text { crt. }\end{array}$ & Toponim & Administrativ & B & C & F & T & Descriere & Localizare & Bibliografie \\
\hline
\end{tabular}

\begin{tabular}{|c|c|c|c|c|c|c|c|c|}
\hline 127 & Neprecizat & $\begin{array}{l}\text { Braniștea (com.), } \\
\text { sat V. Alecsandri }\end{array}$ & & $\mathbf{F}$ & $\mathbf{T}$ & Face parte dintr-un șir de tumuli situați la vest de valea Lozova. & $\begin{array}{l}\text { La } 2 \mathrm{~km} \text { vest de intrarea în } \\
\text { satul L. Catargiu, dinspre } \\
\text { Braniștea, și la } 150 \mathrm{~m} \text { sud } \\
\text { de nr. } 126 \text {. }\end{array}$ & - \\
\hline 128 & Neprecizat & $\begin{array}{l}\text { Braniștea (com.), } \\
\text { sat V. Alecsandri }\end{array}$ & $\mathbf{C}$ & $\mathbf{F}$ & $\mathbf{T}$ & Face parte dintr-un șir de tumuli situaţi la vest de valea Lozova. & $\begin{array}{l}\text { La vest de valea Lozova și } \\
\text { la est de V. Alecsandri, la } \\
\text { jumătatea distanței. }\end{array}$ & - \\
\hline 129 & Neprecizat & $\begin{array}{l}\text { Braniștea (com.), } \\
\text { sat V. Alecsandri }\end{array}$ & & $\mathbf{F}$ & $\mathbf{T}$ & Face parte dintr-un șir de tumuli situați la vest de valea Lozova. & $\begin{array}{l}\text { La vest de valea Lozova și } \\
\text { la est de V. Alecsandri, la } \\
\text { jumătatea distanței. }\end{array}$ & - \\
\hline 130 & Neprecizat & $\begin{array}{l}\text { Braniștea (com.), } \\
\text { sat V. Alecsandri }\end{array}$ & & $\mathbf{F}$ & $\mathbf{T}$ & Face parte dintr-un șir de tumuli situați la vest de valea Lozova. & $\begin{array}{l}\text { La vest de valea Lozova și } \\
\text { la est de V. Alecsandri, la } \\
\text { jumătatea distanței. }\end{array}$ & - \\
\hline 131 & Neprecizat & $\begin{array}{l}\text { Braniștea (com.), } \\
\text { sat V. Alecsandri }\end{array}$ & & $\mathbf{F}$ & $\mathbf{T}$ & Face parte dintr-un șir de tumuli situaţi la vest de valea Lozova. & $\begin{array}{l}\text { La vest de valea Lozova și } \\
\text { la est de V. Alecsandri, la } \\
\text { jumătatea distanței. }\end{array}$ & - \\
\hline 132 & Neprecizat & $\begin{array}{l}\text { Branisțea (com.), } \\
\text { sat V. Alecsandri }\end{array}$ & & $\mathbf{F}$ & $\mathbf{T}$ & Face parte dintr-un șir de tumuli situați la vest de valea Lozova. & $\begin{array}{l}\text { La vest de valea Lozova și } \\
\text { la est de V. Alecsandri, la } \\
\text { jumătatea distanței. }\end{array}$ & - \\
\hline 133 & Neprecizat & $\begin{array}{l}\text { Branisțtea (com.), } \\
\text { sat V. Alecsandri }\end{array}$ & & $\mathbf{F}$ & $T$ & Face parte dintr-un șir de tumuli situaţi la vest de valea Lozova. & $\begin{array}{l}\text { La vest de valea Lozova şi } \\
\text { la est de V. Alecsandri, la } \\
\text { jumătatea distanței. }\end{array}$ & - \\
\hline 134 & Neprecizat & $\begin{array}{l}\text { Braniștea (com.), } \\
\text { sat V. Alecsandri }\end{array}$ & & $\mathbf{F}$ & $\mathbf{T}$ & Face parte dintr-un șir de tumuli situați la vest de valea Lozova. & $\begin{array}{l}\text { La vest de valea Lozova și } \\
\text { la est de V. Alecsandri, la } \\
\text { jumătatea distanței. }\end{array}$ & - \\
\hline 135 & Neprecizat & $\begin{array}{l}\text { Braniștea (com.), } \\
\text { sat V. Alecsandri }\end{array}$ & & $\mathbf{F}$ & $T$ & Face parte dintr-un șir de tumuli situați la vest de valea Lozova. & $\begin{array}{l}\text { La vest de valea Lozova și } \\
\text { la est de V. Alecsandri, la } \\
\text { jumătatea distanței. }\end{array}$ & - \\
\hline 136 & Neprecizat & $\begin{array}{l}\text { Braniștea (com.), } \\
\text { sat V. Alecsandri }\end{array}$ & & $\mathbf{F}$ & $\mathbf{T}$ & Face parte dintr-un șir de tumuli situaţi la vest de valea Lozova. & $\begin{array}{l}\text { La vest de valea Lozova și } \\
\text { la est de V. Alecsandri, la } \\
\text { jumătatea distanței. }\end{array}$ & - \\
\hline 137 & Neprecizat & $\begin{array}{l}\text { Braniștea (com.), } \\
\text { sat V. Alecsandri }\end{array}$ & & $\mathbf{F}$ & $\mathbf{T}$ & Face parte dintr-un șir de tumuli situați la vest de valea Lozova. & $\begin{array}{l}\text { La vest de valea Lozova și } \\
\text { la est de V. Alecsandri, la } \\
\text { jumătatea distanței. }\end{array}$ & - \\
\hline 138 & Neprecizat & $\begin{array}{l}\text { Braniștea (com.), } \\
\text { sat V. Alecsandri }\end{array}$ & & $\mathbf{F}$ & $\mathbf{T}$ & Face parte dintr-un șir de tumuli situaţi la vest de valea Lozova. & $\begin{array}{l}\text { La vest de valea Lozova și } \\
\text { la est de V. Alecsandri, la } \\
\text { jumătatea distanței. }\end{array}$ & - \\
\hline 139 & Neprecizat & $\begin{array}{l}\text { Braniștea (com.), } \\
\text { sat V. Alecsandri }\end{array}$ & & $\mathbf{F}$ & $\mathbf{T}$ & Face parte dintr-un șir de tumuli situaţi la vest de valea Lozova. & $\begin{array}{l}\text { La vest de valea Lozova și } \\
\text { la est de V. Alecsandri, la } \\
\text { jumătatea distanței. }\end{array}$ & - \\
\hline 140 & Neprecizat & $\begin{array}{l}\text { Braniștea (com.), } \\
\text { sat V. Alecsandri }\end{array}$ & & $\mathbf{F}$ & $\mathbf{T}$ & Face parte dintr-un șir de tumuli situați la vest de valea Lozova. & $\begin{array}{l}\text { La vest de valea Lozova și } \\
\text { la est de V. Alecsandri, la } \\
\text { jumătatea distanței. }\end{array}$ & - \\
\hline
\end{tabular}




\begin{tabular}{|c|c|c|c|c|c|c|c|c|c|}
\hline $\begin{array}{l}\text { Nr. } \\
\text { crt. }\end{array}$ & Toponim & Administrativ & B & C & $\mathbf{F}$ & $\mathbf{T}$ & Descriere & Localizare & Bibliografie \\
\hline
\end{tabular}

\begin{tabular}{|c|c|c|c|c|c|c|c|c|c|}
\hline 141 & Neprecizat & $\begin{array}{l}\text { Braniștea (com.), } \\
\text { sat V. Alecsandri }\end{array}$ & & & $\mathbf{F}$ & $\mathbf{T}$ & Face parte dintr-un șir de tumuli situați la vest de valea Lozova. & $\begin{array}{l}\text { La vest de valea Lozova și } \\
\text { la est de V. Alecsandri, la } \\
\text { jumătatea distanței. }\end{array}$ & - \\
\hline 142 & Neprecizat & $\begin{array}{l}\text { Braniștea (com.), } \\
\text { sat V. Alecsandri }\end{array}$ & & $\mathbf{C}$ & $\mathbf{F}$ & $\mathbf{T}$ & Face parte dintr-un șir de tumuli situați la vest de valea Lozova. & $\begin{array}{l}\text { La vest de valea Lozova și } \\
\text { la est de V. Alecsandri, la } \\
\text { jumătatea distanței. }\end{array}$ & - \\
\hline 143 & Neprecizat & $\begin{array}{l}\text { Braniștea (com.), } \\
\text { sat V. Alecsandri }\end{array}$ & $\mathbf{B}$ & $\mathbf{C}$ & $\mathbf{F}$ & $\mathbf{T}$ & $\begin{array}{l}\text { Dimensiuni: diam. } 35 \mathrm{~m} \text {, h. o înălțime de cca } 1 \mathrm{~m} \text {. Face parte dintr-un șir } \\
\text { de tumuli situați la vest de valea Lozova. }\end{array}$ & $\begin{array}{l}\text { La vest de valea Lozova și } \\
\text { la est de V. Alecsandri, la } \\
\text { jumătatea distanței. }\end{array}$ & $\begin{array}{l}\text { Brudiu 1991, 52; } \\
\text { Brudiu 2003, 93-136, } \\
\text { nr. } 186 .\end{array}$ \\
\hline 144 & Neprecizat & $\begin{array}{l}\text { Braniștea (com.), } \\
\text { sat V. Alecsandri }\end{array}$ & & $\mathbf{C}$ & $\mathbf{F}$ & $\mathbf{T}$ & Face parte dintr-un șir de tumuli situați la vest de valea Lozova. & $\begin{array}{l}\text { La vest de valea Lozova și } \\
\text { la est de V. Alecsandri, la } \\
\text { jumătatea distanței. }\end{array}$ & - \\
\hline 145 & Neprecizat & $\begin{array}{l}\text { Braniștea (com.), } \\
\text { sat V. Alecsandri }\end{array}$ & & $\mathbf{C}$ & $\mathbf{F}$ & $\mathbf{T}$ & Face parte dintr-un șir de tumuli situați la vest de valea Lozova. & $\begin{array}{l}\text { La vest de valea Lozova şi } \\
\text { la est de V. Alecsandri, la } \\
\text { jumătatea distanței. }\end{array}$ & - \\
\hline 146 & Neprecizat & $\begin{array}{l}\text { Braniştea (com.), } \\
\text { sat V. Alecsandri }\end{array}$ & & $\mathbf{C}$ & $\mathbf{F}$ & $\mathbf{T}$ & Face parte dintr-un șir de tumuli situați la vest de valea Lozova. & $\begin{array}{l}\text { La vest de valea Lozova şi } \\
\text { la est de V. Alecsandri, la } \\
\text { jumătatea distanței. }\end{array}$ & - \\
\hline 147 & Neprecizat & $\begin{array}{l}\text { Braniştea (com.), } \\
\text { sat V. Alecsandri }\end{array}$ & & $\mathbf{C}$ & $\mathbf{F}$ & $\mathbf{T}$ & Face parte dintr-un șir de tumuli situați la vest de valea Lozova. & $\begin{array}{l}\text { La vest de valea Lozova și } \\
\text { la est de V. Alecsandri, la } \\
\text { jumătatea distanței. }\end{array}$ & - \\
\hline 148 & Neprecizat & $\begin{array}{l}\text { Braniștea (com.), } \\
\text { sat V. Alecsandri }\end{array}$ & & $\mathbf{C}$ & $\mathbf{F}$ & $\mathbf{T}$ & Face parte dintr-un șir de tumuli situați la vest de valea Lozova. & $\begin{array}{l}\text { La vest de valea Lozova şi } \\
\text { la est de V. Alecsandri, la } \\
\text { jumătatea distanței. }\end{array}$ & - \\
\hline 149 & Neprecizat & $\begin{array}{l}\text { Braniștea (com.), } \\
\text { sat V. Alecsandri }\end{array}$ & & $\mathbf{C}$ & $\mathbf{F}$ & $\mathbf{T}$ & Face parte dintr-un șir de tumuli situați la vest de valea Lozova. & $\begin{array}{l}\text { La vest de valea Lozova și } \\
\text { la est de V. Alecsandri, la } \\
\text { jumătatea distanței. }\end{array}$ & - \\
\hline 150 & Neprecizat & $\begin{array}{l}\text { Braniştea (com.), } \\
\text { sat V. Alecsandri }\end{array}$ & & $\mathbf{C}$ & $\mathbf{F}$ & $\mathbf{T}$ & Face parte dintr-un șir de tumuli situați la vest de valea Lozova. & $\begin{array}{l}\text { La vest de valea Lozova și } \\
\text { la est de V. Alecsandri, la } \\
\text { jumătatea distanței. }\end{array}$ & - \\
\hline 151 & Neprecizat & $\begin{array}{l}\text { Braniștea (com.), } \\
\text { sat V. Alecsandri }\end{array}$ & & $\mathbf{C}$ & $\mathbf{F}$ & $\mathbf{T}$ & Face parte dintr-un șir de tumuli situați la vest de valea Lozova. & $\begin{array}{l}\text { La vest de valea Lozova și } \\
\text { la est de V. Alecsandri, la } \\
\text { jumătatea distanței. }\end{array}$ & - \\
\hline 152 & Neprecizat & $\begin{array}{l}\text { Braniștea (com.), } \\
\text { sat V. Alecsandri }\end{array}$ & & & $\mathbf{F}$ & $\mathbf{T}$ & Face parte dintr-un șir de tumuli situați la vest de valea Lozova. & $\begin{array}{l}\text { La vest de valea Lozova şi } \\
\text { la est de V. Alecsandri, la } \\
\text { jumătatea distanței. }\end{array}$ & - \\
\hline 153 & Neprecizat & $\begin{array}{l}\text { Braniştea (com.), } \\
\text { sat V. Alecsandri }\end{array}$ & & & $\mathbf{F}$ & $\mathbf{T}$ & Face parte dintr-un șir de 3 tumuli situați la nord de satul V. Alecsandri & $\begin{array}{l}\text { La } 1 \text { km nord de satul V. } \\
\text { Alecsandri. }\end{array}$ & - \\
\hline 154 & Neprecizat & $\begin{array}{l}\text { Braniștea (com.), } \\
\text { sat V. Alecsandri }\end{array}$ & & & $\mathbf{F}$ & $\mathbf{T}$ & Face parte dintr-un șir de 3 tumuli situați la nord de satul V. Alecsandri & $\begin{array}{l}\text { La } 800 \text { m nord de satul V. } \\
\text { Alecsandri. }\end{array}$ & - \\
\hline 155 & Neprecizat & $\begin{array}{l}\text { Braniștea (com.), } \\
\text { sat V. Alecsandri }\end{array}$ & & & $\mathbf{F}$ & $\mathbf{T}$ & Face parte dintr-un șir de 3 tumuli situați la nord de satul V. Alecsandri & $\begin{array}{l}\text { La } 600 \text { m nord de satul V. } \\
\text { Alecsandri. }\end{array}$ & - \\
\hline
\end{tabular}




\begin{tabular}{|c|c|c|c|c|c|c|c|c|c|}
\hline $\begin{array}{l}\text { Nr. } \\
\text { crt. }\end{array}$ & Toponim & Administrativ & B & $\mathbf{C}$ & $\mathbf{F}$ & $\mathbf{T}$ & Descriere & Localizare & Bibliografie \\
\hline
\end{tabular}

\begin{tabular}{|c|c|c|c|c|c|c|c|c|c|}
\hline 156 & Neprecizat & $\begin{array}{l}\text { Braniştea (com.), } \\
\text { sat V. Alecsandri }\end{array}$ & & & $\mathbf{F}$ & $\mathbf{T}$ & Face parte dintr-un şir de tumuli situați la vest de valea Lozova. & $\begin{array}{l}\text { La vest de valea Lozova și } \\
\text { la est de V. Alecsandri, la } \\
\text { jumătatea distanței. }\end{array}$ & - \\
\hline 157 & Neprecizat & $\begin{array}{l}\text { Braniștea (com.), } \\
\text { sat V. Alecsandri }\end{array}$ & & & $\mathbf{F}$ & $\mathbf{T}$ & Face parte dintr-un șir de tumuli situați la vest de valea Lozova. & $\begin{array}{l}\text { La vest de valea Lozova și } \\
\text { la est de V. Alecsandri, la } \\
\text { jumătatea distanței. }\end{array}$ & - \\
\hline 158 & Neprecizat & $\begin{array}{l}\text { Braniștea (com.), } \\
\text { sat V. Alecsandri }\end{array}$ & & & $\mathbf{F}$ & $\mathbf{T}$ & Face parte dintr-un șir de tumuli situați la vest de valea Lozova. & $\begin{array}{l}\text { La vest de valea Lozova şi } \\
\text { la est de V. Alecsandri, la } \\
\text { jumătatea distanței. }\end{array}$ & - \\
\hline 159 & Neprecizat & $\begin{array}{l}\text { Braniştea (com.), } \\
\text { sat V. Alecsandri }\end{array}$ & & & $\mathbf{F}$ & $\mathbf{T}$ & Face parte dintr-un șir de tumuli situați la vest de valea Lozova. & $\begin{array}{l}\text { La vest de valea Lozova și } \\
\text { la est de V. Alecsandri, la } \\
\text { jumătatea distanței. }\end{array}$ & - \\
\hline 160 & Neprecizat & $\begin{array}{l}\text { Braniștea (com.) } \\
\text { sat Braniștea }\end{array}$ & & $\mathbf{C}$ & $\mathbf{F}$ & $\mathbf{T}$ & - & $\begin{array}{l}\text { Pe dealul Greaca, la 2,50 } \\
\text { km nord vest de Movila } \\
\text { Traian (nr. 194) }\end{array}$ & - \\
\hline 161 & Neprecizat & $\begin{array}{l}\text { Braniștea (com.) } \\
\text { sat Braniștea }\end{array}$ & & & $\mathbf{F}$ & $\mathbf{T}$ & Face parte dintr-un grup de patru tumuli. & $\begin{array}{l}\text { Pe dealul Greaca, la } 1 \mathrm{~km} \\
\text { sud vest de nr. } 160 . \text { Face } \\
\text { parte dintr-un grup de patru } \\
\text { tumuli. }\end{array}$ & - \\
\hline 162 & Neprecizat & $\begin{array}{l}\text { Braniștea (com.) } \\
\text { sat Braniștea }\end{array}$ & & & $\mathbf{F}$ & $\mathbf{T}$ & Face parte dintr-un grup de patru tumuli. & $\begin{array}{l}\text { Pe dealul Greaca, la } 1 \mathrm{~km} \\
\text { sud vest de nr. } 160 . \text { Face } \\
\text { parte dintr-un grup de patru } \\
\text { tumuli. }\end{array}$ & - \\
\hline 163 & Neprecizat & $\begin{array}{l}\text { Braniștea (com.) } \\
\text { sat Braniștea }\end{array}$ & B & $\mathbf{C}$ & $\mathbf{F}$ & $\mathbf{T}$ & $\begin{array}{l}\text { Dimensiuni: diam. } 40 \text { m, h. } 2 \text { m. Face parte dintr-un grup de patru } \\
\text { tumuli. }\end{array}$ & $\begin{array}{l}\text { Pe dealul Greaca, la } 1 \mathrm{~km} \\
\text { sud vest de nr. } 160 . \text { Face } \\
\text { parte dintr-un grup de patru } \\
\text { tumuli. }\end{array}$ & $\begin{array}{l}\text { Brudiu 1991, 52; } \\
\text { Brudiu 2003, 93-136, } \\
\text { nr. } 191 .\end{array}$ \\
\hline 164 & Neprecizat & $\begin{array}{l}\text { Braniştea (com.), } \\
\text { sat Braniștea }\end{array}$ & & & $\mathbf{F}$ & $\mathbf{T}$ & Face parte dintr-un grup de patru tumuli. & $\begin{array}{l}\text { Pe dealul Greaca, la } 1 \mathrm{~km} \\
\text { sud vest de nr. } 160 . \text { Face } \\
\text { parte dintr-un grup de patru } \\
\text { tumuli. }\end{array}$ & - \\
\hline 165 & Neprecizat & $\begin{array}{c}\text { Braniștea (com.) } \\
\text { sat Braniștea }\end{array}$ & & & $\mathbf{F}$ & $\mathbf{T}$ & - & $\begin{array}{l}\text { Pe dealul Greaca, la } 2 \mathrm{~km} \\
\text { vest de „Valul lui Traian”. }\end{array}$ & - \\
\hline 166 & Neprecizat & $\begin{array}{c}\text { Braniștea (com.) } \\
\text { sat Braniștea }\end{array}$ & & & $\mathbf{F}$ & $\mathbf{T}$ & - & $\begin{array}{l}\text { Pe dealul Greaca, la } 2 \mathrm{~km} \\
\text { vest de „Valul lui Traian”. }\end{array}$ & - \\
\hline 167 & Neprecizat & $\begin{array}{c}\text { Braniștea (com.) } \\
\text { sat Braniștea }\end{array}$ & & & $\mathbf{F}$ & $\mathbf{T}$ & - & $\begin{array}{l}\text { Pe dealul Greaca, la } 2,30 \mathrm{~km} \\
\text { vest de ,Valul lui Traian”. }\end{array}$ & - \\
\hline 168 & Neprecizat & $\begin{array}{l}\text { Braniştea (com.) } \\
\text { sat Braniștea }\end{array}$ & & & $\mathbf{F}$ & $\mathbf{T}$ & - & $\begin{array}{l}\text { Pe dealul Greaca, la } 2,40 \mathrm{~km} \\
\text { vest de,,Valul lui Traian”. }\end{array}$ & - \\
\hline 169 & Neprecizat & $\begin{array}{l}\text { Schela - fostă } \\
\text { Lascăr Catargiu } \\
\text { (com.), sat Schela }\end{array}$ & B & & & & Dimensiuni: diam. 32 m, h. 1 m. & $\begin{array}{l}\text { La sud de localitate în } \\
\text { apropiere de hotarul cu } \\
\text { comuna Braniștea. }\end{array}$ & $\begin{array}{l}\text { Brudiu 1991, 51, nr. } \\
\text { 187; Brudiu 2003, 111, } \\
\text { nr. } 187 .\end{array}$ \\
\hline
\end{tabular}




\begin{tabular}{|c|c|c|c|c|c|c|c|c|c|}
\hline $\begin{array}{l}\text { Nr. } \\
\text { crt. }\end{array}$ & Toponim & Administrativ & B & $\mathbf{C}$ & $\mathbf{F}$ & $\mathbf{T}$ & Descriere & Localizare & Bibliografie \\
\hline
\end{tabular}

\begin{tabular}{|c|c|c|c|c|c|c|c|c|c|}
\hline 170 & $\begin{array}{l}\text { Mormântul } \\
\text { Tătarului }\end{array}$ & $\begin{array}{l}\text { Schela }- \text { fostă } \\
\text { Lascăr Catargiu } \\
\text { (com.), sat Schela }\end{array}$ & $\mathbf{B}$ & $\mathbf{C}$ & $\mathbf{F}$ & $\mathbf{T}$ & $\begin{array}{l}\text { Dimensiuni: diam. } 2-3 \text { m înălțime și un diametru de } 15-20 \text { m. Pe vârful } \\
\text { acestei tumuli exista o cruce din piatră cu inscripție ilizibilă, dar care a } \\
\text { dispărut după } 1921 \text {. }\end{array}$ & $\begin{array}{l}\text { Pe versantul estic al văii } \\
\text { Lozova, pe dealul } \\
\text { Mormântul Tătarului, la } 4 \\
\text { km nord de localitatea } \\
\text { Braniştea și } 3 \text { km sud de } \\
\text { Schela. }\end{array}$ & $\begin{array}{l}\text { Croitoru } 2013,52, \mathrm{v} \\
\text { nota } 137 .\end{array}$ \\
\hline 171 & Neprecizat & $\begin{array}{l}\text { Braniștea (com.) } \\
\text { sat Braniștea }\end{array}$ & & & $\mathbf{F}$ & $\mathbf{T}$ & $\begin{array}{l}\text { Face parte dintr-un şir de } 7 \text { tumuli dispuși la cca } 100 \text { m distanță una față } \\
\text { de cealaltă. }\end{array}$ & $\begin{array}{l}\text { Pe dealul Șerbești, la cca } \\
1,30 \mathrm{~km} \text { est de Balta } \\
\text { Lozova. }\end{array}$ & - \\
\hline 172 & Neprecizat & $\begin{array}{l}\text { Braniștea (com.) } \\
\text { sat Braniștea }\end{array}$ & & & $\mathbf{F}$ & $\mathbf{T}$ & $\begin{array}{l}\text { Face parte dintr-un şir de } 7 \text { tumuli dispuși la cca } 100 \text { m distanță una față } \\
\text { de cealaltă. }\end{array}$ & $\begin{array}{l}\text { Pe dealul Șerbeşti, la cca } \\
1,30 \mathrm{~km} \text { est de Balta } \\
\text { Lozova. }\end{array}$ & - \\
\hline 173 & Neprecizat & $\begin{array}{l}\text { Braniștea (com.), } \\
\text { sat Braniștea }\end{array}$ & & & $\mathbf{F}$ & $\mathbf{T}$ & $\begin{array}{l}\text { Face parte dintr-un şir de } 7 \text { tumuli dispuși la cca } 100 \text { m distanță una față } \\
\text { de cealaltă. }\end{array}$ & $\begin{array}{l}\text { Pe dealul Șerbești, la cca } \\
1,30 \mathrm{~km} \text { est de Balta } \\
\text { Lozova. }\end{array}$ & - \\
\hline 174 & Neprecizat & $\begin{array}{l}\text { Braniștea (com.) } \\
\text { sat Braniștea }\end{array}$ & & & $\mathbf{F}$ & $\mathbf{T}$ & $\begin{array}{l}\text { Face parte dintr-un şir de } 7 \text { tumuli dispuși la cca } 100 \text { m distanță una față } \\
\text { de cealaltă. }\end{array}$ & $\begin{array}{l}\text { Pe dealul Șerbești, la cca } \\
1,30 \mathrm{~km} \text { est de Balta } \\
\text { Lozova. }\end{array}$ & - \\
\hline 175 & Neprecizat & $\begin{array}{l}\text { Braniștea (com.) } \\
\text { sat Braniștea }\end{array}$ & & & $\mathbf{F}$ & $\mathbf{T}$ & $\begin{array}{l}\text { Face parte dintr-un șir de } 7 \text { tumuli dispuși la cca } 100 \text { m distanță una față } \\
\text { de cealaltă. }\end{array}$ & $\begin{array}{l}\text { Pe dealul Șerbeşti, la cca } \\
1,30 \mathrm{~km} \text { est de Balta } \\
\text { Lozova. }\end{array}$ & - \\
\hline 176 & Movila Jipa & $\begin{array}{l}\text { Braniștea (com.), } \\
\text { sat Braniștea }\end{array}$ & $\mathbf{B}$ & $\mathbf{C}$ & $\mathbf{F}$ & $\mathbf{T}$ & $\begin{array}{l}\text { Dimensiuni: diam. } 46 \text { m, h. o înălțime de cca } 2 \text { m. Face parte dintr-un șir } \\
\text { de } 7 \text { tumuli dispuși la cca } 100 \text { m distanță una față de cealaltă. }\end{array}$ & $\begin{array}{l}\text { Pe dealul Şerbeşti, la cca } \\
1,30 \mathrm{~km} \text { est de Balta } \\
\text { Lozova. }\end{array}$ & $\begin{array}{l}\text { Brudiu 1991, 52; } \\
\text { Brudiu 2003, 93-136, } \\
\text { nr. } 188 .\end{array}$ \\
\hline 177 & Neprecizat & $\begin{array}{l}\text { Braniștea (com.) } \\
\text { sat Braniștea }\end{array}$ & & & $\mathbf{F}$ & $\mathbf{T}$ & $\begin{array}{l}\text { Face parte dintr-un şir de } 7 \text { tumuli dispuşi la cca } 100 \text { m distanță una față } \\
\text { de cealaltă. }\end{array}$ & $\begin{array}{l}\text { Pe dealul Șerbești, la cca } \\
1,30 \mathrm{~km} \text { est de Balta } \\
\text { Lozova. }\end{array}$ & - \\
\hline 178 & Neprecizat & $\begin{array}{l}\text { Braniștea (com.) } \\
\text { sat Braniștea }\end{array}$ & B & $\mathbf{C}$ & $\mathbf{F}$ & $\mathbf{T}$ & Dimensiuni: diam. 32 m, h. 1 m. & $\begin{array}{l}\text { Movilă situată la } 1,20 \mathrm{~km} \\
\text { est de movila Jipa. } \\
\text { Extremitatea sudică a } \\
\text { dealului Greaca. }\end{array}$ & $\begin{array}{l}\text { Brudiu 1991, 52; } \\
\text { Brudiu 2003, 93-136, } \\
\text { nr. } 190 .\end{array}$ \\
\hline 179 & Neprecizat & $\begin{array}{l}\text { Braniștea (com.) } \\
\text { sat Braniștea }\end{array}$ & & & $\mathbf{F}$ & $\mathbf{T}$ & - & $\begin{array}{l}\text { La extremitatea sudică a } \\
\text { dealului Greaca, la } 800 \mathrm{~m} \\
\text { est de nr. } 178 .\end{array}$ & - \\
\hline 180 & Neprecizat & $\begin{array}{l}\text { Braniștea (com.), } \\
\text { sat Braniștea }\end{array}$ & & & $\mathbf{F}$ & $\mathbf{T}$ & - & La 100 m nord de nr 179. & - \\
\hline 181 & Neprecizat & $\begin{array}{l}\text { Braniștea (com.), } \\
\text { sat Braniștea }\end{array}$ & & & $\mathbf{F}$ & $\mathbf{T}$ & - & La 130 m nord de nr 179. & - \\
\hline 182 & Neprecizat & $\begin{array}{l}\text { Braniștea (com.) } \\
\text { sat Braniștea }\end{array}$ & & & $\mathbf{F}$ & $\mathbf{T}$ & - & $\begin{array}{l}\text { La } 1,40 \mathrm{~km} \text { est de nr. } 178 \text { şi } \\
\text { la } 1 \mathrm{~km} \text { vest de „Valul lui } \\
\text { Traian”. }\end{array}$ & - \\
\hline 183 & Neprecizat & $\begin{array}{l}\text { Braniștea (com.) } \\
\text { sat Braniștea }\end{array}$ & & & $\mathbf{F}$ & $\mathbf{T}$ & - & $\begin{array}{l}\text { La } 1,40 \mathrm{~km} \text { est de nr. } 178 \text { și } \\
\text { la } 1 \mathrm{~km} \text { vest de „Valul lui } \\
\text { Traian”. }\end{array}$ & - \\
\hline
\end{tabular}




\begin{tabular}{|c|c|c|c|c|c|c|c|c|c|}
\hline $\begin{array}{l}\text { Nr. } \\
\text { crt. }\end{array}$ & Toponim & Administrativ & B & $\mathbf{C}$ & $\mathbf{F}$ & $\mathbf{T}$ & Descriere & Localizare & Bibliografie \\
\hline
\end{tabular}

\begin{tabular}{|c|c|c|c|c|c|c|c|c|c|}
\hline 184 & $\begin{array}{l}\text { Movila } \\
\text { Braniștea }\end{array}$ & $\begin{array}{l}\text { Braniștea (com.), } \\
\text { sat Braniștea }\end{array}$ & B & $\mathbf{C}$ & $\mathbf{F}$ & $\mathbf{T}$ & Dimensiuni: diam. 35 m, h. o înălțime de cca 1 m. & $\begin{array}{l}\text { Se află la } 800 \mathrm{~m} \text { est de } \\
\text { comună și } 1,20 \mathrm{~km} \text { nord de } \\
\text { calea ferată. }\end{array}$ & $\begin{array}{l}\text { Brudiu 1991, 52; } \\
\text { Brudiu 2003, 93-136, } \\
\text { nr. } 189 .\end{array}$ \\
\hline 185 & Neprecizat & $\begin{array}{l}\text { Braniștea (com.), } \\
\text { sat Braniștea }\end{array}$ & & $\mathbf{C}$ & $\mathbf{F}$ & $\mathbf{T}$ & - & $\begin{array}{l}\text { La cca } 900 \text { m est de satul } \\
\text { Braniştea și la } 900 \text { m nord } \\
\text { de calea ferată. }\end{array}$ & 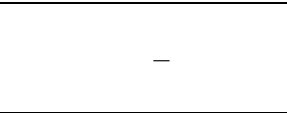 \\
\hline 186 & Neprecizat & $\begin{array}{l}\text { Braniștea (com.), } \\
\text { sat Braniștea }\end{array}$ & & $\mathbf{C}$ & $\mathbf{F}$ & $\mathbf{T}$ & - & La 300 m est de nr. 185. & - \\
\hline 187 & Neprecizat & $\begin{array}{l}\text { Braniștea (com.), } \\
\text { sat Braniștea }\end{array}$ & & $\mathbf{C}$ & $\mathbf{F}$ & $\mathbf{T}$ & - & $\begin{array}{l}\text { La } 320 \text { m sud-est de nr. } \\
186 .\end{array}$ & - \\
\hline 188 & Neprecizat & $\begin{array}{l}\text { Braniștea (com.), } \\
\text { sat Traian }\end{array}$ & & $\mathbf{C}$ & $\mathbf{F}$ & $\mathbf{T}$ & - & $\begin{array}{l}\text { La } 400 \text { m sud-est de nr. } \\
\text { 187. Se află la circa } 1 \mathrm{~km} \\
\text { nord-vest de satul Traian. }\end{array}$ & - \\
\hline 189 & Neprecizat & $\begin{array}{l}\text { Șendreni (com.), } \\
\text { sat Şerbeştii } \\
\text { Vechi }\end{array}$ & & $\mathbf{C}$ & $\mathbf{F}$ & & - & $\begin{array}{l}\text { Pe dealul greaca la } 1,80 \mathrm{~km} \\
\text { nord-vest de Movila Traian } \\
\text { (nr. 194). }\end{array}$ & - \\
\hline 190 & Neprecizat & $\begin{array}{l}\text { Șendreni (com.), } \\
\text { sat Şerbeştii } \\
\text { Vechi }\end{array}$ & & & $\mathbf{F}$ & & - & $\begin{array}{l}\text { În nordul teritoriului } \\
\text { comunei, la } 200 \text { m vest de } \\
\text { km } 11,20 \text { al Valului lui } \\
\text { Traian (măsurat din Traian). }\end{array}$ & - \\
\hline 191 & Neprecizat & $\begin{array}{l}\text { Șendreni (com.), } \\
\text { sat Șerbeştii } \\
\text { Vechi }\end{array}$ & & & $\mathbf{F}$ & & - & $\begin{array}{l}\text { La cca } 100 \text { m nord-vest de } \\
\text { Movila Traian (nr. 194). }\end{array}$ & - \\
\hline 192 & Neprecizat & $\begin{array}{l}\text { Șendreni (com.), } \\
\text { sat Șerbeştii } \\
\text { Vechi }\end{array}$ & & & $\mathbf{F}$ & & - & $\begin{array}{l}\text { La cca } 100 \text { m nord-vest de } \\
\text { Movila Traian (nr. 194). }\end{array}$ & - \\
\hline 193 & Neprecizat & $\begin{array}{l}\text { Șendreni (com.), } \\
\text { sat Șerbesstii } \\
\text { Vechi }\end{array}$ & & & $\mathbf{F}$ & & Dimensiuni: diam. 30 m, h. 1 m. & $\begin{array}{l}\text { La cca } 100 \text { m nord-vest de } \\
\text { Movila Traian (nr. 194). }\end{array}$ & $\begin{array}{l}\text { Brudiu 1991, 52; } \\
\text { Brudiu 2003, 93-136, } \\
\text { nr. } 192 .\end{array}$ \\
\hline 194 & $\begin{array}{l}\text { Movila } \\
\text { Traian }\end{array}$ & $\begin{array}{l}\text { Șendreni (com.), } \\
\text { sat Șerbeştii } \\
\text { Vechi }\end{array}$ & B & $\mathbf{C}$ & $\mathbf{F}$ & & Dimensiuni: diam. 25 m, h. 1 m. & $\begin{array}{l}\text { Pe „Valul lui Traian”, la } 7 \\
\text { km nord de satul Traian. }\end{array}$ & $\begin{array}{l}\text { Brudiu 1991, 52; } \\
\text { Brudiu 2003, 93-136, } \\
\text { nr. } 193 .\end{array}$ \\
\hline 195 & Neprecizat & $\begin{array}{l}\text { Șendreni (com.), } \\
\text { sat Șerbeştii } \\
\text { Vechi }\end{array}$ & & & $\mathbf{F}$ & $\mathbf{T}$ & Grup de tumuli. & $\begin{array}{l}\text { Pe dealul Greaca, la } 2 \mathrm{~km} \\
\text { vest de „Valul lui Traian”. }\end{array}$ & - \\
\hline 196 & Neprecizat & $\begin{array}{l}\text { Șendreni (com.), } \\
\text { sat Șerbeștii } \\
\text { Vechi }\end{array}$ & & & $\mathbf{F}$ & $\mathbf{T}$ & Grup de tumuli. & $\begin{array}{l}\text { Pe dealul Greaca, la } 2 \mathrm{~km} \\
\text { vest de „Valul lui Traian”. }\end{array}$ & - \\
\hline 197 & Neprecizat & $\begin{array}{l}\text { Șendreni (com.), } \\
\text { sat Șerbesstii } \\
\text { Vechi }\end{array}$ & & & $\mathbf{F}$ & $\mathbf{T}$ & Grup de tumuli. & $\begin{array}{l}\text { Pe dealul Greaca, la } 2 \text { km } \\
\text { vest de „Valul lui Traian”. }\end{array}$ & - \\
\hline 198 & Neprecizat & $\begin{array}{l}\text { Șendreni (com.), } \\
\text { sat Şerbeştii } \\
\text { Vechi }\end{array}$ & & & $\mathbf{F}$ & $\mathbf{T}$ & Grup de tumuli. & $\begin{array}{l}\text { Pe dealul Greaca, la } 2 \mathrm{~km} \\
\text { vest de „Valul lui Traian”. }\end{array}$ & - \\
\hline
\end{tabular}




\begin{tabular}{|c|c|c|c|c|c|c|c|c|c|}
\hline $\begin{array}{l}\text { Nr. } \\
\text { crt. }\end{array}$ & Toponim & Administrativ & B & $\mathbf{C}$ & $\mathbf{F}$ & $\mathbf{T}$ & Descriere & Localizare & Bibliografie \\
\hline
\end{tabular}

\begin{tabular}{|c|c|c|c|c|c|c|c|c|c|}
\hline 199 & Neprecizat & $\begin{array}{l}\text { Șendreni (com.), } \\
\text { sat Șerbeștii } \\
\text { Vechi }\end{array}$ & & & $\mathbf{F}$ & $\mathbf{T}$ & Grup de tumuli. & $\begin{array}{l}\text { Pe dealul Greaca, la } 2 \text { km } \\
\text { vest de „Valul lui Traian”. }\end{array}$ & - \\
\hline 200 & Neprecizat & $\begin{array}{l}\text { Șendreni (com.), } \\
\text { sat Şerbeştii } \\
\text { Vechi }\end{array}$ & $\mathbf{B}$ & & $\mathbf{F}$ & & Dimensiuni: diam. 31 m, h. 1 m. & $\begin{array}{l}\text { La hotarul de nord-est cu } \\
\text { comuna Smârdan, aproape } \\
\text { de obârșia văii Rusca Mare. }\end{array}$ & $\begin{array}{l}\text { Brudiu 1991, 52; } \\
\text { Brudiu 2003, 93-136, } \\
\text { nr. } 194 .\end{array}$ \\
\hline 201 & Neprecizat & $\begin{array}{l}\text { Șendreni (com.), } \\
\text { sat Șerbeștii } \\
\text { Vechi }\end{array}$ & & & $\mathbf{F}$ & $\mathbf{T}$ & - & $\begin{array}{l}\text { Pe aceeassi curbă de nivel, la } \\
2,30 \mathrm{~km} \text { sud de nr. } 200 \text {. }\end{array}$ & 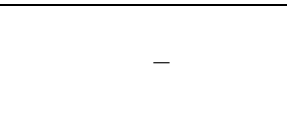 \\
\hline 202 & Neprecizat & $\begin{array}{l}\text { Șendreni (com.), } \\
\text { sat Şerbesstii } \\
\text { Vechi }\end{array}$ & & & $\mathbf{F}$ & $\mathbf{T}$ & Grup de trei tumuli. & $\begin{array}{l}\text { La } 700 \text { m est de Valul lui } \\
\text { Traian şi la } 2 \text { km est de } \\
\text { valea Rusca Mare. }\end{array}$ & - \\
\hline 203 & Neprecizat & $\begin{array}{l}\text { Șendreni (com.), } \\
\text { sat Șerbeștii } \\
\text { Vechi }\end{array}$ & & & $\mathbf{F}$ & $\mathbf{T}$ & Grup de trei tumuli. & $\begin{array}{l}\text { La } 700 \text { m est de Valul lui } \\
\text { Traian şi la } 2 \mathrm{~km} \text { est de } \\
\text { valea Rusca Mare. }\end{array}$ & - \\
\hline 204 & Neprecizat & $\begin{array}{l}\text { Șendreni (com.), } \\
\text { sat Şerbeștii } \\
\text { Vechi }\end{array}$ & & $\mathbf{C}$ & $\mathbf{F}$ & $\mathbf{T}$ & Grup de trei tumuli. & $\begin{array}{l}\text { La } 700 \text { m est de Valul lui } \\
\text { Traian şi la } 2 \text { km est de } \\
\text { valea Rusca Mare. }\end{array}$ & - \\
\hline 205 & Neprecizat & $\begin{array}{l}\text { Șendreni (com.), } \\
\text { sat Șerbeștii } \\
\text { Vechi }\end{array}$ & & $\mathbf{C}$ & $\mathbf{F}$ & $\mathbf{T}$ & - & La 1 km est de nr. 204. & - \\
\hline 206 & Neprecizat & $\begin{array}{l}\text { Șendreni (com.), } \\
\text { sat Șendreni }\end{array}$ & & $\mathbf{C}$ & $\mathbf{F}$ & $\mathbf{T}$ & - & $\begin{array}{l}\text { Pe interfluviul dintre văile } \\
\text { Rusca Mare și Rusca Mică. }\end{array}$ & - \\
\hline 207 & $\begin{array}{l}\text { Movila } \\
\text { Spânului }\end{array}$ & $\begin{array}{l}\text { Șendreni (com.), } \\
\text { sat Șendreni }\end{array}$ & & $\mathbf{C}$ & $\mathbf{F}$ & & - & $\begin{array}{l}\text { Pe dealul Spânului la } 3 \mathrm{~km} \\
\text { est de Balta Mălina și la } \\
6,30 \mathrm{~km} \text { nord de Râul Siret. }\end{array}$ & - \\
\hline 208 & Neprecizat & $\begin{array}{l}\text { Șendreni (com.), } \\
\text { sat Șendreni }\end{array}$ & & & $\mathbf{F}$ & & - & $\begin{array}{l}\text { Pe dealul Cornet, la } 2,10 \\
\text { km vest de podul peste } \\
\text { Mălina. }\end{array}$ & - \\
\hline 209 & Neprecizat & $\begin{array}{l}\text { Șendreni (com.), } \\
\text { sat Șendreni }\end{array}$ & & & $\mathbf{F}$ & & - & $\begin{array}{l}\text { Pe dealul Cornet, la } 2 \mathrm{~km} \\
\text { vest de podul peste Mălina. }\end{array}$ & - \\
\hline 210 & Neprecizat & $\begin{array}{l}\text { Șendreni (com.), } \\
\text { sat Șendreni }\end{array}$ & & & $\mathbf{F}$ & & - & $\begin{array}{l}\text { Pe dealul Cornet, la } 1,80 \\
\text { km vest de podul peste } \\
\text { Mălina. }\end{array}$ & - \\
\hline 211 & $\begin{array}{l}\text { Movila } \\
\text { Cornet }\end{array}$ & $\begin{array}{l}\text { Şendreni (com.), } \\
\text { sat Șendreni }\end{array}$ & B & $\mathbf{C}$ & $\mathbf{F}$ & & Dimensiuni: diam. 25 m, h. 1 m. & $\begin{array}{l}\text { Pe dealul Cornet, la } 1,60 \\
\text { km vest de podul peste } \\
\text { Mălina. }\end{array}$ & $\begin{array}{l}\text { Brudiu 1991, 52; } \\
\text { Brudiu 2003, 93-136, } \\
\text { nr. } 202 .\end{array}$ \\
\hline 212 & Neprecizat & $\begin{array}{l}\text { Şendreni (com.), } \\
\text { sat Șendreni }\end{array}$ & $\mathbf{B}$ & & $\mathbf{F}$ & $\mathbf{T}$ & Dimensiuni: diam. $22 \mathrm{~m}$, h. $0,80 \mathrm{~m}$. & $\begin{array}{l}\text { Face parte dintr-un șir de } \\
\text { tumuli situați pe versantul } \\
\text { vestic al Bălții Mălina, la } \\
\text { cca } 900 \text { m de aceasta. }\end{array}$ & $\begin{array}{l}\text { Brudiu 2003, 93-136, } \\
\text { nr. } 393 .\end{array}$ \\
\hline
\end{tabular}




\begin{tabular}{|c|c|c|c|c|c|c|c|c|c|}
\hline $\begin{array}{l}\text { Nr. } \\
\text { crt. }\end{array}$ & Toponim & Administrativ & B & C & F & T & Descriere & Localizare & Bibliografie \\
\hline
\end{tabular}

\begin{tabular}{|c|c|c|c|c|c|c|c|c|c|}
\hline 213 & Neprecizat & $\begin{array}{l}\text { Șendreni (com.), } \\
\text { sat Șendreni }\end{array}$ & B & C & $\mathbf{F}$ & $\mathbf{T}$ & Dimensiuni: diam. 28 m, h. 1 m. & $\begin{array}{l}\text { Face parte dintr-un şir de } \\
\text { tumuli situatii pe versantul } \\
\text { vestic al Băltii Mălina, la } \\
\text { cca } 900 \mathrm{~m} \text { de aceasta. }\end{array}$ & $\begin{array}{l}\text { Brudiu 2003, 93-136, } \\
\text { nr. } 394 .\end{array}$ \\
\hline 214 & Neprecizat & $\begin{array}{l}\text { Șendreni (com.), } \\
\text { sat Șendreni }\end{array}$ & $\mathbf{B}$ & & $\mathbf{F}$ & $\mathbf{T}$ & Dimensiuni: diam. 20 m, h. $0,70 \mathrm{~m}$. & $\begin{array}{l}\text { Face parte dintr-un şir de } \\
\text { tumuli situați pe versantul } \\
\text { vestic al Bălții Mălina, la } \\
\text { cca } 900 \mathrm{~m} \text { de aceasta. }\end{array}$ & $\begin{array}{l}\text { Brudiu 2003, 93-136, } \\
\text { nr. } 391 .\end{array}$ \\
\hline 215 & Neprecizat & $\begin{array}{l}\text { Șendreni (com.), } \\
\text { sat Șendreni }\end{array}$ & B & & $\mathbf{F}$ & $\mathbf{T}$ & Dimensiuni: diam. 14 m, h. 0,60 m. & $\begin{array}{l}\text { Face parte dintr-un şir de } \\
\text { tumuli situatii pe versantul } \\
\text { vestic al Băltii Mălina, la } \\
\text { cca } 900 \text { m de aceasta. }\end{array}$ & $\begin{array}{l}\text { Brudiu 2003, 93-136, } \\
\text { nr. } 392 .\end{array}$ \\
\hline 216 & Neprecizat & $\begin{array}{l}\text { Șendreni (com.), } \\
\text { sat Șendreni }\end{array}$ & B & & $\mathbf{F}$ & $\mathbf{T}$ & Dimensiuni: diam. 15 m, h. 0,50 m. & $\begin{array}{l}\text { Face parte dintr-un şir de } \\
\text { tumuli situatii pe versantul } \\
\text { vestic al Băltii Mălina, la } \\
\text { cca } 900 \text { m de aceasta. }\end{array}$ & $\begin{array}{l}\text { Brudiu 2003, 93-136, } \\
\text { nr. } 389 .\end{array}$ \\
\hline 217 & Neprecizat & $\begin{array}{l}\text { Șendreni (com.), } \\
\text { sat Șendreni }\end{array}$ & B & & $\mathbf{F}$ & $\mathbf{T}$ & Dimensiuni: diam. 19 m, h. 0,60 m. & $\begin{array}{l}\text { Face parte dintr-un şir de } \\
\text { tumuli situați pe versantul } \\
\text { vestic al Bălții Mălina, la } \\
\text { cca } 900 \text { m de aceasta. }\end{array}$ & $\begin{array}{l}\text { Brudiu 2003, 93-136, } \\
\text { nr. } 390 .\end{array}$ \\
\hline 218 & $\begin{array}{l}\text { Tumulul de } \\
\text { la Smârdan }\end{array}$ & $\begin{array}{l}\text { Șendreni (com.), } \\
\text { sat Șendreni }\end{array}$ & $\mathbf{B}$ & & $\mathbf{F}$ & $\mathbf{T}$ & $\begin{array}{l}\text { Tumulul, cu diametrul de } 50 \mathrm{~m} \text { și o ônălțime de } 2 \mathrm{~m} \text {, a fost cercetat în } \\
\text { anul 1989, în cadrul unor săpături de salvare. Tumulul face parte dintr- } \\
\text { un grup de tumuli ce se întinde pe o distanță de } 20 \text { de km pe faleza } \\
\text { vestică a lacului Mălina. Tumulul avea o singură înmormântare, fără } \\
\text { intervenții ulterioare, iar mormântul a aparținut unei femei de origine } \\
\text { sarmatică. Inventarul este compus din: perle din sticlă de diferite culori } \\
\text { și mărimi, podoabe din aur (mai multe podoabe pentru veșminte din foiță } \\
\text { de aur precum flori cu frunze sau mici tuburi din aur) ș.a. }\end{array}$ & $\begin{array}{l}\text { Face parte dintr-un şir de } \\
\text { tumuli situați pe versantul } \\
\text { vestic al Bălții Mălina, la } \\
\text { cca } 900 \text { m de aceasta. }\end{array}$ & $\begin{array}{l}\text { Brudiu 1991, 52; } \\
\text { Brudiu 2003, 93-136, } \\
\text { nr. 197. }\end{array}$ \\
\hline 219 & Neprecizat & $\begin{array}{l}\text { Smârdan (com.), } \\
\text { sat Smârdan }\end{array}$ & B & & $\mathbf{F}$ & $\mathbf{T}$ & Dimensiuni: diam. 30 m, h. 1 m. & $\begin{array}{l}\text { Face parte dintr-un şir de } \\
\text { tumuli situati pe versantul } \\
\text { vestic al Băltii Mălina, la } \\
\text { cca } 900 \text { m de aceasta. }\end{array}$ & $\begin{array}{l}\text { Brudiu 1991, 52; } \\
\text { Brudiu 2003, 93-136, } \\
\text { nr. 198. }\end{array}$ \\
\hline 220 & Neprecizat & $\begin{array}{l}\text { Smârdan (com.), } \\
\text { sat Smârdan }\end{array}$ & B & & $\mathbf{F}$ & $\mathbf{T}$ & Dimensiuni: diam. 30 m, h. 1 m. & $\begin{array}{l}\text { Face parte dintr-un şir de } \\
\text { tumuli situatii pe versantul } \\
\text { vestic al Băltii Mălina, la } \\
\text { cca } 900 \text { m de aceasta. }\end{array}$ & $\begin{array}{l}\text { Brudiu 1991, 52; } \\
\text { Brudiu 2003, 93-136, } \\
\text { nr. } 199 .\end{array}$ \\
\hline 221 & Neprecizat & $\begin{array}{l}\text { Smârdan (com.), } \\
\text { sat Smârdan }\end{array}$ & B & $\mathbf{C}$ & $\mathbf{F}$ & $\mathbf{T}$ & Dimensiuni: diam. 40 m, h. 2 m. & $\begin{array}{l}\text { Face parte dintr-un şir de } \\
\text { tumuli situati pe versantul } \\
\text { vestic al Bălții Mălina, la } \\
\text { cca } 900 \mathrm{~m} \text { de aceasta. }\end{array}$ & $\begin{array}{l}\text { Brudiu 1991, 52; } \\
\text { Brudiu 2003, 93-136, } \\
\text { nr. } 200 .\end{array}$ \\
\hline
\end{tabular}




\begin{tabular}{|c|c|c|c|c|c|c|c|c|c|}
\hline $\begin{array}{l}\text { Nr. } \\
\text { crt. }\end{array}$ & Toponim & Administrativ & B & $\mathbf{C}$ & $\mathbf{F}$ & $\mathbf{T}$ & Descriere & Localizare & Bibliografie \\
\hline
\end{tabular}

\begin{tabular}{|c|c|c|c|c|c|c|c|c|c|}
\hline 222 & Neprecizat & $\begin{array}{l}\text { Smârdan (com.), } \\
\text { sat Smârdan }\end{array}$ & $\mathbf{B}$ & & $\mathbf{F}$ & $\mathbf{T}$ & Dimensiuni: diam. 40 m, h. 2 m. & $\begin{array}{l}\text { Face parte dintr-un șir de } \\
\text { tumuli situați pe versantul } \\
\text { vestic al Bălții Mălina, la } \\
\text { cca } 900 \text { m de aceasta. }\end{array}$ & $\begin{array}{l}\text { Brudiu 1991, 52; } \\
\text { Brudiu 2003, 93-136, } \\
\text { nr. } 201 .\end{array}$ \\
\hline 223 & Neprecizat & $\begin{array}{l}\text { Șendreni (com.), } \\
\text { sat Șendreni }\end{array}$ & $\mathbf{B}$ & & $\mathbf{F}$ & $\mathbf{T}$ & Dimensiuni: diam. 25 m, h. 0,80 m. & $\begin{array}{l}\text { Face parte dintr-un şir de } \\
\text { tumuli situați pe versantul } \\
\text { vestic al Bălții Mălina, la } \\
\text { cca } 900 \text { m de aceasta. }\end{array}$ & $\begin{array}{l}\text { Brudiu 2003, 93-136, } \\
\text { nr. } 388 .\end{array}$ \\
\hline 224 & Neprecizat & $\begin{array}{l}\text { Șendreni (com.), } \\
\text { sat Șendreni }\end{array}$ & & & $\mathbf{F}$ & $\mathbf{T}$ & - & $\begin{array}{l}\text { Se află pe Dealul Spânul la } \\
4 \text { km nord de comună şi la } \\
2,80 \text { km vest de Balta } \\
\text { Mălina. }\end{array}$ & - \\
\hline 225 & Neprecizat & $\begin{array}{l}\text { Șendreni (com.), } \\
\text { sat Șendreni }\end{array}$ & & & $\mathbf{F}$ & $\mathbf{T}$ & - & $\begin{array}{l}\text { Pe dealul Spânului la } 700 \text { m } \\
\text { sud-vest de nr. } 224 .\end{array}$ & - \\
\hline 226 & Neprecizat & $\begin{array}{l}\text { Șendreni (com.), } \\
\text { sat Şerbeştii } \\
\text { Vechi }\end{array}$ & & $\mathbf{C}$ & $\mathbf{F}$ & $\mathbf{T}$ & - & $\begin{array}{l}\text { Pe versantul vestic al văii } \\
\text { Rusca Mare la 2,80 km nord } \\
\text { de Șerbeștii Vechi. }\end{array}$ & - \\
\hline 227 & Neprecizat & $\begin{array}{l}\text { Șendreni (com.), } \\
\text { sat Șerbeștii } \\
\text { Vechi }\end{array}$ & & $\mathbf{C}$ & $\mathbf{F}$ & $\mathbf{T}$ & - & $\begin{array}{l}\text { Pe versantul vestic al văii } \\
\text { Rusca Mare la 2,60 km nord } \\
\text { de Șerbestii Vechi. }\end{array}$ & - \\
\hline 228 & Neprecizat & $\begin{array}{l}\text { Șendreni (com.), } \\
\text { sat Şerbeștii } \\
\text { Vechi }\end{array}$ & & $\mathbf{C}$ & $\mathbf{F}$ & $\mathbf{T}$ & - & $\begin{array}{l}\text { Pe versantul vestic al văii } \\
\text { Rusca Mare la 2,40 km nord } \\
\text { de Șerbeștii Vechi. }\end{array}$ & - \\
\hline 229 & Neprecizat & $\begin{array}{l}\text { Şendreni (com.), } \\
\text { sat Șerbeștii } \\
\text { Vechi }\end{array}$ & & $\mathbf{C}$ & $\mathbf{F}$ & $\mathbf{T}$ & - & $\begin{array}{l}\text { Pe versantul vestic al văii } \\
\text { Rusca Mare la 2,20 km nord } \\
\text { de Șerbeștii Vechi. }\end{array}$ & - \\
\hline 230 & Neprecizat & $\begin{array}{l}\text { Șendreni (com.), } \\
\text { sat Şerbeştii } \\
\text { Vechi }\end{array}$ & B & $\mathbf{C}$ & $\mathbf{F}$ & $\mathbf{T}$ & Dimensiuni: diam. 30 m, h. 0,70 m. & $\begin{array}{l}\text { Pe versantul vestic al văii } \\
\text { Rusca Mare la } 2 \text { km nord de } \\
\text { Șerbeștii Vechi. }\end{array}$ & $\begin{array}{l}\text { Brudiu 2003, 93-136, } \\
\text { nr. } 336 .\end{array}$ \\
\hline 231 & $\begin{array}{l}\text { Movila la } \\
\text { „Bărbuță” }\end{array}$ & $\begin{array}{l}\text { Șendreni (com.), } \\
\text { sat Şerbeştii } \\
\text { Vechi }\end{array}$ & B & $\mathbf{C}$ & $\mathbf{F}$ & $\mathbf{T}$ & $\begin{array}{l}\text { Este menționată existența unui tumul, diametrul de } 40 \mathrm{~m} \text { și înălțimea de } \\
4 \text { m, distrus în anul 1985. Se menționează și unele descoperiri făcute cu } \\
\text { acest prilej, printre care resturi osteologice umane și cărămizi provenind } \\
\text { de la un sarcofag roman. }\end{array}$ & $\begin{array}{l}\text { Pe versantul vestic al văii } \\
\text { Rusca Mare la } 1,80 \text { km nord } \\
\text { de Șerbeștii Vechi. }\end{array}$ & $\begin{array}{l}\text { Brudiu 1991, 54; } \\
\text { Brudiu 2003, 93-136, } \\
\text { nr. } 334 .\end{array}$ \\
\hline 232 & Neprecizat & $\begin{array}{l}\text { Șendreni (com.), } \\
\text { sat Şerbeștii } \\
\text { Vechi }\end{array}$ & $\mathbf{B}$ & $\mathbf{C}$ & $\mathbf{F}$ & $\mathbf{T}$ & Dimensiuni: diam. 30 m, h. 0,60 m. & $\begin{array}{l}\text { Pe versantul vestic al văii } \\
\text { Rusca Mare la 1,60 km nord } \\
\text { de Șerbestii Vechi. }\end{array}$ & $\begin{array}{l}\text { Brudiu 1991, 54; } \\
\text { Brudiu 2003, 93-136, } \\
\text { nr. } 335 .\end{array}$ \\
\hline 233 & Neprecizat & $\begin{array}{l}\text { Şendreni (com.), } \\
\text { sat Şerbesstii } \\
\text { Vechi } \\
\end{array}$ & & $\mathbf{C}$ & $\mathbf{F}$ & $\mathbf{T}$ & - & $\begin{array}{l}\text { Pe versantul vestic al văii } \\
\text { Rusca Mare la } 1 \mathrm{~km} \text { nord de } \\
\text { calea ferată. }\end{array}$ & (1) \\
\hline 234 & Neprecizat & $\begin{array}{l}\text { Șendreni (com.), } \\
\text { sat Şerbeștii } \\
\text { Vechi }\end{array}$ & & & $\mathbf{F}$ & & Face parte dintr-un grup de 15 tumuli. & $\begin{array}{l}\text { La } 1,60 \mathrm{~km} \text { nord de } \\
\text { localitate. }\end{array}$ & - \\
\hline
\end{tabular}




\begin{tabular}{|c|c|c|c|c|c|c|c|c|c|}
\hline $\begin{array}{l}\text { Nr. } \\
\text { crt. }\end{array}$ & Toponim & Administrativ & B & $\mathbf{C}$ & $\mathbf{F}$ & $\mathbf{T}$ & Descriere & Localizare & Bibliografie \\
\hline
\end{tabular}

\begin{tabular}{|c|c|c|c|c|c|c|c|c|}
\hline 235 & Neprecizat & $\begin{array}{l}\text { Șendreni (com.) } \\
\text { sat Șerbesstii } \\
\text { Vechi }\end{array}$ & $\mathbf{B}$ & & $\mathbf{F}$ & $\begin{array}{l}\text { Dimensiuni: diam. } 40 \mathrm{~m}, \mathrm{~h} .1,50 \mathrm{~m} \text {. A fost nivelat în anul 1985. Face } \\
\text { parte dintr-un grup de } 15 \text { tumuli. }\end{array}$ & $\begin{array}{l}\text { La } 1,60 \mathrm{~km} \text { nord de } \\
\text { localitate. }\end{array}$ & $\begin{array}{l}\text { Brudiu 1991, 52; } \\
\text { Brudiu 2003, 93-136, } \\
\text { nr. } 203 .\end{array}$ \\
\hline 236 & Neprecizat & $\begin{array}{l}\text { Șendreni (com.), } \\
\text { sat Șerbeștii } \\
\text { Vechi }\end{array}$ & & & $\mathbf{F}$ & Face parte dintr-un grup de 15 tumuli. & $\begin{array}{l}\text { La } 1,60 \mathrm{~km} \text { nord de } \\
\text { localitate.. }\end{array}$ & 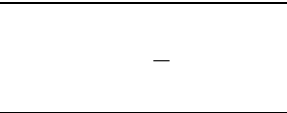 \\
\hline 237 & Neprecizat & $\begin{array}{l}\text { Șendreni (com.), } \\
\text { sat Șerbeștii } \\
\text { Vechi }\end{array}$ & & & $\mathbf{F}$ & Face parte dintr-un grup de 15 tumuli. & $\begin{array}{l}\text { La } 1,60 \mathrm{~km} \text { nord de } \\
\text { localitate. }\end{array}$ & - \\
\hline 238 & Neprecizat & $\begin{array}{l}\text { Șendreni (com.), } \\
\text { sat Șerbeştii } \\
\text { Vechi }\end{array}$ & $\mathbf{B}$ & & $\mathbf{F}$ & $\begin{array}{l}\text { Cercetările au fost începute în } 1988 \text { și au fost efectuate de către M. } \\
\text { Brudiu. Este vorba despre un tumul aplatizat, înălțimea păstrată la } \\
\text { momentul cercetării fiind de } 0,90 \text { m, iar diametrul de } 25 \text { m. Tumulul } \\
\text { prezintă intervenții antropice din cel de-al Doilea Război Mondial. Au } \\
\text { fost descoperite } 5 \text { morminte de inhumație aparținând culturii Imanaia } \\
\text { (începutul epocii bronzului), databile după un vas din mormântul M5. } \\
\text { Face parte dintr-un grup de } 15 \text { tumuli. }\end{array}$ & $\begin{array}{l}\text { La } 1,60 \mathrm{~km} \text { nord de } \\
\text { localitate. }\end{array}$ & $\begin{array}{l}\text { Brudiu 1991, 54; } \\
\text { Brudiu 2003, 71-72, } \\
\text { 93-136, nr. 333. }\end{array}$ \\
\hline 239 & Neprecizat & $\begin{array}{l}\text { Șendreni (com.) } \\
\text { sat Șerbeștii } \\
\text { Vechi }\end{array}$ & & & $\mathbf{F}$ & Face parte dintr-un grup de 15 tumuli. & $\begin{array}{l}\text { La } 1,60 \mathrm{~km} \text { nord de } \\
\text { localitate. }\end{array}$ & - \\
\hline 240 & Neprecizat & $\begin{array}{l}\text { Șendreni (com.), } \\
\text { sat Șerbeștii } \\
\text { Vechi }\end{array}$ & & $\mathbf{C}$ & $\mathbf{F}$ & Face parte dintr-un grup de 15 tumuli. & $\begin{array}{l}\text { La } 1,60 \mathrm{~km} \text { nord de } \\
\text { localitate. }\end{array}$ & - \\
\hline 241 & Neprecizat & $\begin{array}{l}\text { Șendreni (com.) } \\
\text { sat Șerbeștii } \\
\text { Vechi }\end{array}$ & & & $\mathbf{F}$ & Face parte dintr-un grup de 15 tumuli. & $\begin{array}{l}\text { La } 1,60 \mathrm{~km} \text { nord de } \\
\text { localitate. }\end{array}$ & - \\
\hline 242 & Neprecizat & $\begin{array}{l}\text { Șendreni }(\text { com.) } \\
\text { sat Şerbeștii } \\
\text { Vechi }\end{array}$ & B & & $\mathbf{F}$ & $\begin{array}{l}\text { Dimensiuni: diam. } 30 \text { m, h. 0,90 m. Face parte dintr-un grup de } 15 \\
\text { tumuli. }\end{array}$ & $\begin{array}{l}\text { La } 1,60 \mathrm{~km} \text { nord de } \\
\text { localitate. }\end{array}$ & $\begin{array}{l}\text { Brudiu 2003, 93-136, } \\
\text { nr. } 341 .\end{array}$ \\
\hline 243 & Neprecizat & $\begin{array}{l}\text { Șendreni (com.), } \\
\text { sat Şerbeştii } \\
\text { Vechi }\end{array}$ & $\mathbf{B}$ & $\mathbf{C}$ & $\mathbf{F}$ & $\begin{array}{l}\text { Dimensiuni: diam. } 40 \text { m, h. 1,20 m. Face parte dintr-un grup de } 15 \\
\text { tumuli. }\end{array}$ & $\begin{array}{l}\text { La } 1,60 \mathrm{~km} \text { nord de } \\
\text { localitate. }\end{array}$ & $\begin{array}{l}\text { Brudiu 2003, 93-136, } \\
\text { nr. } 337 .\end{array}$ \\
\hline 244 & Neprecizat & $\begin{array}{l}\text { Șendreni (com.), } \\
\text { sat Șendreni }\end{array}$ & $\mathbf{B}$ & & $\mathbf{F}$ & $\begin{array}{l}\text { Dimensiuni: diam. } 30 \text { m, h. 1,10 m. Face parte dintr-un grup de } 15 \\
\text { tumuli. }\end{array}$ & $\begin{array}{l}\text { La } 1,60 \mathrm{~km} \text { nord de } \\
\text { localitate. }\end{array}$ & $\begin{array}{l}\text { Brudiu 1991, 53; } \\
\text { Brudiu 2003, 93-136, } \\
\text { nr. } 236 .\end{array}$ \\
\hline 245 & Neprecizat & $\begin{array}{l}\text { Șendreni (com.), } \\
\text { sat Șendreni }\end{array}$ & & & $\mathbf{F}$ & Face parte dintr-un grup de 15 tumuli. & $\begin{array}{l}\text { La } 1,60 \mathrm{~km} \text { nord de } \\
\text { localitate.. }\end{array}$ & - \\
\hline 246 & Neprecizat & $\begin{array}{l}\text { Șendreni (com.), } \\
\text { sat Șerbeștii } \\
\text { Vechi }\end{array}$ & $\mathbf{B}$ & & $\mathbf{F}$ & $\begin{array}{l}\text { Dimensiuni: diam. } 25 \text { m, h. 0,80 m. Face parte dintr-un grup de } 15 \\
\text { tumuli. }\end{array}$ & $\begin{array}{l}\text { La } 1,60 \mathrm{~km} \text { nord de } \\
\text { localitate.. }\end{array}$ & $\begin{array}{l}\text { Brudiu 2003, 93-136, } \\
\text { nr. } 340 .\end{array}$ \\
\hline 247 & Neprecizat & $\begin{array}{l}\text { Șendreni (com.), } \\
\text { sat Șerbeștii } \\
\text { Vechi }\end{array}$ & B & & $\mathbf{F}$ & $\begin{array}{l}\text { Dimensiuni: diam. } 30 \text { m, h. 0,90 m. Face parte dintr-un grup de } 15 \\
\text { tumuli. }\end{array}$ & $\begin{array}{l}\text { La } 1,60 \mathrm{~km} \text { nord de } \\
\text { localitate. }\end{array}$ & $\begin{array}{l}\text { Brudiu 2003, 93-136, } \\
\text { nr. } 339 .\end{array}$ \\
\hline
\end{tabular}




\begin{tabular}{|l|l|l|l|l|l|l|l|c|c|}
\hline $\begin{array}{l}\text { Nr. } \\
\text { crt. }\end{array}$ & Toponim & Administrativ & B & C & F & T & Descriere & Localizare & Bibliografie \\
\hline
\end{tabular}

\begin{tabular}{|c|c|c|c|c|c|c|c|c|c|}
\hline 248 & Neprecizat & $\begin{array}{l}\text { Șendreni (com.), } \\
\text { sat Şerbeștii } \\
\text { Vechi }\end{array}$ & $\mathbf{B}$ & C & $\mathbf{F}$ & & $\begin{array}{l}\text { Dimensiuni: diam. } 35 \text { m, h. } 0,90 \text { m. Face parte dintr-un grup de } 15 \\
\text { tumuli. }\end{array}$ & $\begin{array}{l}\text { La } 1,60 \mathrm{~km} \text { nord de } \\
\text { localitate. }\end{array}$ & $\begin{array}{l}\text { Brudiu 2003, 93-136, } \\
\text { nr. 338. }\end{array}$ \\
\hline 249 & Neprecizat & $\begin{array}{l}\text { Şendreni (com.), } \\
\text { sat Șendreni }\end{array}$ & & & $\mathbf{F}$ & $\mathbf{T}$ & Face parte dintr-un grup de 23 de tumuli. & $\begin{array}{l}\text { Pe Dealul Tumulini, între } \\
\text { Balta Mălina, la vest, și } \\
\text { valea Tumulini, la est. } \\
\text { Grupul este situat la } 4,30-5 \\
\text { km nord de satul Barboşi. }\end{array}$ & - \\
\hline 250 & Neprecizat & $\begin{array}{l}\text { Șendreni (com.), } \\
\text { sat Șendreni }\end{array}$ & & & $\mathbf{F}$ & $\mathbf{T}$ & Face parte dintr-un grup de 23 de tumuli. & $\begin{array}{l}\text { Pe Dealul Tumulini, între } \\
\text { Balta Mălina, la vest, și } \\
\text { valea Tumulini, la est. } \\
\text { Grupul este situat la } 4,30-5 \\
\text { km nord de satul Barboși. }\end{array}$ & - \\
\hline 251 & Neprecizat & $\begin{array}{l}\text { Şendreni (com.), } \\
\text { sat Șendreni }\end{array}$ & & & $\mathbf{F}$ & $\mathbf{T}$ & Face parte dintr-un grup de 23 de tumuli. & $\begin{array}{l}\text { Pe Dealul Tumulini, între } \\
\text { Balta Mălina, la vest, și } \\
\text { valea Tumulini, la est. } \\
\text { Grupul este situat la } 4,30-5 \\
\text { km nord de satul Barboși. }\end{array}$ & - \\
\hline 252 & Neprecizat & $\begin{array}{l}\text { Şendreni (com.), } \\
\text { sat Şendreni }\end{array}$ & & & $\mathbf{F}$ & $\mathbf{T}$ & Face parte dintr-un grup de 23 de tumuli. & $\begin{array}{l}\text { Pe Dealul Tumulini, între } \\
\text { Balta Mălina, la vest, și } \\
\text { valea Tumulini, la est. } \\
\text { Grupul este situat la 4,30-5 } \\
\text { km nord de satul Barboși. }\end{array}$ & - \\
\hline 253 & Neprecizat & $\begin{array}{l}\text { Şendreni (com.), } \\
\text { sat Şendreni }\end{array}$ & & & $\mathbf{F}$ & $\mathbf{T}$ & Face parte dintr-un grup de 23 de tumuli. & $\begin{array}{l}\text { Pe Dealul Tumulini, între } \\
\text { Balta Mălina, la vest, și } \\
\text { valea Tumulini, la est. } \\
\text { Grupul este situat la } 4,30-5 \\
\text { km nord de satul Barboși. }\end{array}$ & - \\
\hline 254 & Neprecizat & $\begin{array}{l}\text { Şendreni (com.), } \\
\text { sat Şendreni }\end{array}$ & & & $\mathbf{F}$ & $\mathbf{T}$ & Face parte dintr-un grup de 23 de tumuli. & $\begin{array}{l}\text { Pe Dealul Tumulini, între } \\
\text { Balta Mălina, la vest, și } \\
\text { valea Tumulini, la est. } \\
\text { Grupul este situat la } 4,30-5 \\
\text { km nord de satul Barboși. }\end{array}$ & - \\
\hline 255 & Neprecizat & $\begin{array}{l}\text { Şendreni (com.), } \\
\text { sat Şendreni }\end{array}$ & & & $\mathbf{F}$ & $\mathbf{T}$ & Face parte dintr-un grup de 23 de tumuli. & $\begin{array}{l}\text { Pe Dealul Tumulini, între } \\
\text { Balta Mălina, la vest, și } \\
\text { valea Tumulini, la est. } \\
\text { Grupul este situat la } 4,30-5 \\
\text { km nord de satul Barboși. }\end{array}$ & - \\
\hline 256 & Neprecizat & $\begin{array}{l}\text { Şendreni (com.), } \\
\text { sat Şendreni }\end{array}$ & & & $\mathbf{F}$ & $\mathbf{T}$ & Face parte dintr-un grup de 23 de tumuli. & $\begin{array}{l}\text { Pe Dealul Tumulini, între } \\
\text { Balta Mălina, la vest, și } \\
\text { valea Tumulini, la est. } \\
\text { Grupul este situat la } 4,30-5 \\
\text { km nord de satul Barboși. }\end{array}$ & - \\
\hline
\end{tabular}




\begin{tabular}{|c|c|c|c|c|c|c|c|c|c|}
\hline $\begin{array}{l}\text { Nr. } \\
\text { crt. }\end{array}$ & Toponim & Administrativ & B & C & F & T & Descriere & Localizare & Bibliografie \\
\hline
\end{tabular}

\begin{tabular}{|c|c|c|c|c|c|c|c|}
\hline 257 & Neprecizat & $\begin{array}{l}\text { Șendreni (com.), } \\
\text { sat Șendreni }\end{array}$ & $\mathbf{F}$ & $\mathbf{T}$ & Face parte dintr-un grup de 23 de tumuli. & $\begin{array}{l}\text { Pe Dealul Tumulini, între } \\
\text { Balta Mălina, la vest, și } \\
\text { valea Tumulini, la est. } \\
\text { Grupul este situat la 4,30-5 } \\
\text { km nord de satul Barboși. }\end{array}$ & - \\
\hline 258 & Neprecizat & $\begin{array}{l}\text { Șendreni (com.), } \\
\text { sat Șendreni }\end{array}$ & $\mathbf{F}$ & $\mathbf{T}$ & Face parte dintr-un grup de 23 de tumuli. & $\begin{array}{l}\text { Pe Dealul Tumulini, între } \\
\text { Balta Mălina, la vest, şi } \\
\text { valea Tumulini, la est. } \\
\text { Grupul este situat la } 4,30-5 \\
\text { km nord de satul Barboși. }\end{array}$ & - \\
\hline 259 & Neprecizat & $\begin{array}{l}\text { Șendreni (com.), } \\
\text { sat Șendreni }\end{array}$ & $\mathbf{F}$ & $\mathbf{T}$ & Face parte dintr-un grup de 23 de tumuli. & $\begin{array}{l}\text { Pe Dealul Tumulini, între } \\
\text { Balta Mălina, la vest, și } \\
\text { valea Tumulini, la est. } \\
\text { Grupul este situat la } 4,30-5 \\
\text { km nord de satul Barboși. }\end{array}$ & - \\
\hline 260 & Neprecizat & $\begin{array}{l}\text { Șendreni (com.), } \\
\text { sat Șendreni }\end{array}$ & $\mathbf{F}$ & $\mathbf{T}$ & Face parte dintr-un grup de 23 de tumuli. & $\begin{array}{l}\text { Pe Dealul Tumulini, între } \\
\text { Balta Mălina, la vest, și } \\
\text { valea Tumulini, la est. } \\
\text { Grupul este situat la } 4,30-5 \\
\text { km nord de satul Barboși. }\end{array}$ & - \\
\hline 261 & Neprecizat & $\begin{array}{l}\text { Şendreni (com.), } \\
\text { sat Şendreni }\end{array}$ & $\mathbf{F}$ & $\mathbf{T}$ & Face parte dintr-un grup de 23 de tumuli. & $\begin{array}{l}\text { Pe Dealul Tumulini, între } \\
\text { Balta Mălina, la vest, și } \\
\text { valea Tumulini, la est. } \\
\text { Grupul este situat la 4,30-5 } \\
\text { km nord de satul Barboși. }\end{array}$ & - \\
\hline 262 & Neprecizat & $\begin{array}{l}\text { Șendreni (com.), } \\
\text { sat Șendreni }\end{array}$ & $\mathbf{F}$ & $\mathbf{T}$ & Face parte dintr-un grup de 23 de tumuli. & $\begin{array}{l}\text { Pe Dealul Tumulini, între } \\
\text { Balta Mălina, la vest, şi } \\
\text { valea Tumulini, la est. } \\
\text { Grupul este situat la } 4,30-5 \\
\text { km nord de satul Barboși. }\end{array}$ & - \\
\hline 263 & Neprecizat & $\begin{array}{l}\text { Șendreni (com.), } \\
\text { sat Şendreni }\end{array}$ & $\mathbf{F}$ & $\mathbf{T}$ & Face parte dintr-un grup de 23 de tumuli. & $\begin{array}{l}\text { Pe Dealul Tumulini, între } \\
\text { Balta Mălina, la vest, și } \\
\text { valea Tumulini, la est. } \\
\text { Grupul este situat la 4,30-5 } \\
\text { km nord de satul Barboși. }\end{array}$ & - \\
\hline 264 & Neprecizat & $\begin{array}{l}\text { Şendreni (com.), } \\
\text { sat Șendreni }\end{array}$ & $\mathbf{F}$ & $\mathbf{T}$ & Face parte dintr-un grup de 23 de tumuli. & $\begin{array}{l}\text { Pe Dealul Tumulini, între } \\
\text { Balta Mălina, la vest, și } \\
\text { valea Tumulini, la est. } \\
\text { Grupul este situat la 4,30-5 } \\
\text { km nord de satul Barboși. }\end{array}$ & - \\
\hline
\end{tabular}




\begin{tabular}{|c|c|c|c|c|c|c|c|c|c|}
\hline $\begin{array}{l}\text { Nr. } \\
\text { crt. }\end{array}$ & Toponim & Administrativ & B & C & F & T & Descriere & Localizare & Bibliografie \\
\hline
\end{tabular}

\begin{tabular}{|c|c|c|c|c|c|c|c|c|}
\hline 265 & Neprecizat & $\begin{array}{l}\text { Șendreni (com.), } \\
\text { sat Șendreni }\end{array}$ & & $\mathbf{F}$ & $\mathbf{T}$ & Face parte dintr-un grup de 23 de tumuli. & $\begin{array}{l}\text { Pe Dealul Tumulini, între } \\
\text { Balta Mălina, la vest, și } \\
\text { valea Tumulini, la est. } \\
\text { Grupul este situat la } 4,30-5 \\
\text { km nord de satul Barboși. }\end{array}$ & - \\
\hline 266 & Neprecizat & $\begin{array}{l}\text { Șendreni (com.), } \\
\text { sat Șendreni }\end{array}$ & & $\mathbf{F}$ & $\mathbf{T}$ & Face parte dintr-un grup de 23 de tumuli. & $\begin{array}{l}\text { Pe Dealul Tumulini, între } \\
\text { Balta Mălina, la vest, și } \\
\text { valea Tumulini, la est. } \\
\text { Grupul este situat la } 4,30-5 \\
\text { km nord de satul Barboși. }\end{array}$ & - \\
\hline 267 & Neprecizat & $\begin{array}{l}\text { Șendreni (com.), } \\
\text { sat Șendreni }\end{array}$ & & $\mathbf{F}$ & $\mathbf{T}$ & Face parte dintr-un grup de 23 de tumuli. & $\begin{array}{l}\text { Pe Dealul Tumulini, între } \\
\text { Balta Mălina, la vest, și } \\
\text { valea Tumulini, la est. } \\
\text { Grupul este situat la } 4,30-5 \\
\text { km nord de satul Barboși. }\end{array}$ & - \\
\hline 268 & Neprecizat & $\begin{array}{l}\text { Șendreni (com.), } \\
\text { sat Șendreni }\end{array}$ & & $\mathbf{F}$ & $\mathbf{T}$ & Face parte dintr-un grup de 23 de tumuli. & $\begin{array}{l}\text { Pe Dealul Tumulini, între } \\
\text { Balta Mălina, la vest, și } \\
\text { valea Tumulini, la est. } \\
\text { Grupul este situat la } 4,30-5 \\
\text { km nord de satul Barboși. }\end{array}$ & - \\
\hline 269 & Neprecizat & $\begin{array}{l}\text { Șendreni (com.), } \\
\text { sat Șendreni }\end{array}$ & & $\mathbf{F}$ & $\mathbf{T}$ & Face parte dintr-un grup de 23 de tumuli. & $\begin{array}{l}\text { Pe Dealul Tumulini, între } \\
\text { Balta Mălina, la vest, și } \\
\text { valea Tumulini, la est. } \\
\text { Grupul este situat la } 4,30-5 \\
\text { km nord de satul Barboși. }\end{array}$ & - \\
\hline 270 & Neprecizat & $\begin{array}{l}\text { Șendreni (com.), } \\
\text { sat Șendreni }\end{array}$ & & $\mathbf{F}$ & $\mathbf{T}$ & Face parte dintr-un grup de 23 de tumuli. & $\begin{array}{l}\text { Pe Dealul Tumulini, între } \\
\text { Balta Mălina, la vest, și } \\
\text { valea Tumulini, la est. } \\
\text { Grupul este situat la } 4,30-5 \\
\text { km nord de satul Barboși. }\end{array}$ & - \\
\hline 271 & Neprecizat & $\begin{array}{l}\text { Șendreni (com.), } \\
\text { sat Șendreni }\end{array}$ & & $\mathbf{F}$ & $\mathbf{T}$ & Face parte dintr-un grup de 23 de tumuli. & $\begin{array}{l}\text { Pe Dealul Tumulini, între } \\
\text { Balta Mălina, la vest, și } \\
\text { valea Tumulini, la est. } \\
\text { Grupul este situat la } 4,30-5 \\
\text { km nord de satul Barboși. }\end{array}$ & - \\
\hline 272 & Neprecizat & $\begin{array}{l}\text { Șendreni (com.), } \\
\text { sat Șendreni }\end{array}$ & C & & & $\begin{array}{l}\text { Probabil distrus de sistemul de apărare antiaerian al Galațiului din } \\
\text { perioada celui de-al Doilea Război Mondial. }\end{array}$ & $\begin{array}{l}\text { Se află situat la } 2,30 \mathrm{~km} \\
\text { nord-vest de Sendreni, într- } \\
\text { o baterie antiaeriană. }\end{array}$ & - \\
\hline 273 & $\begin{array}{l}\text { Movila } \\
\text { Drumul } \\
\text { Țarnei }\end{array}$ & $\begin{array}{l}\text { Șendreni (com.), } \\
\text { sat Șendreni }\end{array}$ & & $\mathbf{F}$ & & $\begin{array}{l}\text { Tumulul a fost ,cercetat” printr-un sondaj în anul } 1955 \text { de colectivul de } \\
\text { cercetare de la Barboşi. La suprafatăă s-au descoperit numeroase } \\
\text { fragmente ceramice provenind de la mai multe amfore romane, chiupuri } \\
\text { și alte vase de perioadă romană. }\end{array}$ & $\begin{array}{l}\text { La } 1 \mathrm{~km} \text { nord de localitate, } \\
\text { în apropierea Bălții Mălina. }\end{array}$ & $\begin{array}{l}\text { Gostar, Săpăturile și } \\
\text { sondajele de la } \\
\text { Şendreni-Bărboși, 507, } \\
\text { nr. V; Croitoru 2014, } \\
152 .\end{array}$ \\
\hline
\end{tabular}




\begin{tabular}{|c|c|c|c|c|c|c|c|c|c|}
\hline $\begin{array}{l}\text { Nr. } \\
\text { crt. }\end{array}$ & Toponim & Administrativ & B & $\mathbf{C}$ & $\mathbf{F}$ & $\mathbf{T}$ & Descriere & Localizare & Bibliografie \\
\hline
\end{tabular}

\begin{tabular}{|c|c|c|c|c|c|c|c|c|c|}
\hline 274 & $\begin{array}{l}\text { Movila } \\
\text { Hameiului }\end{array}$ & $\begin{array}{l}\text { Smârdan (com.), } \\
\text { sat Smârdan }\end{array}$ & $\mathbf{B}$ & $\mathbf{C}$ & & & Dimensiuni: diam. 45 m, h. 3 m. & $\begin{array}{l}\text { Se află la nord de Valea } \\
\text { Negrei, pe dealul Ibrianu, la } \\
2,30 \mathrm{~km} \text { nord-est de } \\
\text { localitatea Negrea. }\end{array}$ & $\begin{array}{l}\text { Brudiu 1991, 51; } \\
\text { Brudiu 2003, 93-136, } \\
\text { nr. } 163 .\end{array}$ \\
\hline 275 & Neprecizat & $\begin{array}{l}\text { Smârdan (com.), } \\
\text { sat Smârdan }\end{array}$ & & $\mathbf{C}$ & $\mathbf{F}$ & $\mathbf{T}$ & $\begin{array}{l}\text { Un şir de tumuli, nr. } 275-284 \text {, care se continuă, pe teritoriul comunei } \\
\text { Șendreni, cu nr. } 212-223 \text { și } 489-490 \text {. Cei } 10 \text { tumuli de pe teritoriul } \\
\text { comunei Smârdan se întind pe o distanță de cca } 3,50 \mathrm{~km} \text {, iar întregul şir } \\
\text { de tumuli are cca } 5,70 \mathrm{~km} \text {. }\end{array}$ & $\begin{array}{l}\text { La cca } 2 \mathrm{~km} \text { vest de } \\
\text { comună, pe versantul vestic } \\
\text { al văii Mălina. }\end{array}$ & - \\
\hline 276 & Neprecizat & $\begin{array}{l}\text { Smârdan (com.), } \\
\text { sat Smârdan }\end{array}$ & & & $\mathbf{F}$ & $\mathbf{T}$ & $\begin{array}{l}\text { Un şir de tumuli, nr. } 275-284 \text {, care se continuă, pe teritoriul comunei } \\
\text { Șendreni, cu nr. } 212-223 \text { și } 489-490 \text {. Cei } 10 \text { tumuli de pe teritoriul } \\
\text { comunei Smârdan se întind pe o distanță de cca } 3,50 \mathrm{~km} \text {, iar întregul şir } \\
\text { de tumuli are cca } 5,70 \mathrm{~km} \text {. }\end{array}$ & $\begin{array}{l}\text { La cca } 2 \mathrm{~km} \text { vest de } \\
\text { comună, pe versantul vestic } \\
\text { al văii Mălina. }\end{array}$ & - \\
\hline 277 & Neprecizat & $\begin{array}{l}\text { Smârdan (com.), } \\
\text { sat Smârdan }\end{array}$ & & & $\mathbf{F}$ & $\mathbf{T}$ & $\begin{array}{l}\text { Un şir de tumuli, nr. } 275-284 \text {, care se continuă, pe teritoriul comunei } \\
\text { Șendreni, cu nr. } 212-223 \text { și } 489-490 \text {. Cei } 10 \text { tumuli de pe teritoriul } \\
\text { comunei Smârdan se întind pe o distanță de cca } 3,50 \mathrm{~km} \text {, iar întregul șir } \\
\text { de tumuli are cca } 5,70 \mathrm{~km} \text {. }\end{array}$ & $\begin{array}{l}\text { La cca } 2 \mathrm{~km} \text { vest de } \\
\text { comună, pe versantul vestic } \\
\text { al văii Mălina. }\end{array}$ & - \\
\hline 278 & Neprecizat & $\begin{array}{l}\text { Smârdan (com.), } \\
\text { sat Smârdan }\end{array}$ & & & $\mathbf{F}$ & $\mathbf{T}$ & $\begin{array}{l}\text { Un șir de tumuli, nr. } 275-284 \text {, care se continuă, pe teritoriul comunei } \\
\text { Şendreni, cu nr. } 212-223 \text { și } 489-490 \text {. Cei } 10 \text { tumuli de pe teritoriul } \\
\text { comunei Smârdan se întind pe o distanță de cca } 3,50 \mathrm{~km} \text {, iar întregul șir } \\
\text { de tumuli are cca } 5,70 \mathrm{~km} \text {. }\end{array}$ & $\begin{array}{l}\text { La cca } 2 \mathrm{~km} \text { vest de } \\
\text { comună, pe versantul vestic } \\
\text { al văii Mălina. }\end{array}$ & - \\
\hline 279 & Neprecizat & $\begin{array}{l}\text { Smârdan (com.), } \\
\text { sat Smârdan }\end{array}$ & $\mathbf{B}$ & & $\mathbf{F}$ & $\mathbf{T}$ & $\begin{array}{l}\text { Dimensiuni: diam. } 45 \text { m, h. } 2 \text { m înălțime, are gropi de intervenție } \\
\text { moderne. Un șir de tumuli, nr. } 275-284 \text {, care se continuă, pe teritoriul } \\
\text { comunei Șendreni, cu nr. } 212-223 \text { și } 489-490 \text {. Cei } 10 \text { tumuli de pe } \\
\text { teritoriul comunei Smârdan se întind pe o distanță de cca } 3,50 \mathrm{~km} \text {, iar } \\
\text { întregul șir de tumuli are cca } 5,70 \mathrm{~km} \text {. }\end{array}$ & $\begin{array}{l}\text { La cca } 2 \mathrm{~km} \text { vest de } \\
\text { comună, pe versantul vestic } \\
\text { al văii Mălina. }\end{array}$ & $\begin{array}{l}\text { Brudiu 1991, 52; } \\
\text { Brudiu 2003, 93-136, } \\
\text { nr. } 196 .\end{array}$ \\
\hline 280 & Neprecizat & $\begin{array}{l}\text { Smârdan (com.), } \\
\text { sat Smârdan }\end{array}$ & B & & $\mathbf{F}$ & $\mathbf{T}$ & $\begin{array}{l}\text { Dimensiuni: diam. } 40 \text { m, h. } 1,20 \text { m. Un șir de tumuli, nr. } 275-284 \text {, care } \\
\text { se continuă, pe teritoriul comunei Șendreni, cu nr. } 212-223 \text { și } 489-490 \text {. } \\
\text { Cei } 10 \text { tumuli de pe teritoriul comunei Smârdan se întind pe o distanță de } \\
\text { cca } 3,50 \mathrm{~km} \text {, iar întregul șir de tumuli are cca } 5,70 \mathrm{~km} \text {. }\end{array}$ & $\begin{array}{l}\text { La cca } 2 \mathrm{~km} \text { vest de } \\
\text { comună, pe versantul vestic } \\
\text { al văii Mălina. }\end{array}$ & $\begin{array}{l}\text { Brudiu 2003, 93-136, } \\
\text { nr. } 397 .\end{array}$ \\
\hline 281 & Neprecizat & $\begin{array}{l}\text { Smârdan (com.), } \\
\text { sat Smârdan }\end{array}$ & $\mathbf{B}$ & $\mathbf{C}$ & $\mathbf{F}$ & $\mathbf{T}$ & $\begin{array}{l}\text { Dimensiuni: diam. } 40 \text { m, h. } 1,50 \text { m. Un șir de tumuli, nr. } 275-284 \text {, care } \\
\text { se continuă, pe teritoriul comunei Șendreni, cu nr. } 212-223 \text { și } 489-490 \text {. } \\
\text { Cei } 10 \text { tumuli de pe teritoriul comunei Smârdan se întind pe o distanță de } \\
\text { cca } 3,50 \mathrm{~km} \text {, iar întregul șir de tumuli are cca } 5,70 \mathrm{~km} \text {. }\end{array}$ & $\begin{array}{l}\text { La cca } 2 \mathrm{~km} \text { vest de } \\
\text { comună, pe versantul vestic } \\
\text { al văii Mălina. }\end{array}$ & $\begin{array}{l}\text { Brudiu 2003, 93-136, } \\
\text { nr. } 398 .\end{array}$ \\
\hline 282 & Neprecizat & $\begin{array}{l}\text { Smârdan (com.), } \\
\text { sat Smârdan }\end{array}$ & B & & $\mathbf{F}$ & $\mathbf{T}$ & $\begin{array}{l}\text { Dimensiuni: diam. } 31 \mathrm{~m} \text {, h. } 1,10 \mathrm{~m} \text {. Un șir de tumuli, nr. 275-284, care } \\
\text { se continuă, pe teritoriul comunei Șendreni, cu nr. } 212-223 \text { și } 489-490 \text {. } \\
\text { Cei } 10 \text { tumuli de pe teritoriul comunei Smârdan se întind pe o distanță de } \\
\text { cca } 3,50 \mathrm{~km} \text {, iar întregul șir de tumuli are cca } 5,70 \mathrm{~km} \text {. }\end{array}$ & $\begin{array}{l}\text { La cca } 2 \mathrm{~km} \text { vest de } \\
\text { comună, pe versantul vestic } \\
\text { al văii Mălina. }\end{array}$ & $\begin{array}{l}\text { Brudiu 2003, 93-136, } \\
\text { nr. } 396 .\end{array}$ \\
\hline 283 & Neprecizat & $\begin{array}{l}\text { Smârdan (com.), } \\
\text { sat Smârdan }\end{array}$ & $\mathbf{B}$ & & $\mathbf{F}$ & $\mathbf{T}$ & $\begin{array}{l}\text { Dimensiuni: diam. } 40 \mathrm{~m}, \mathrm{~h} .2 \mathrm{~m} \text {. Un șir de tumuli, nr. } 275-284 \text {, care se } \\
\text { continuă, pe teritoriul comunei Șendreni, cu nr. } 212-223 \text { și } 489-490 \text {. Cei } \\
10 \text { tumuli de pe teritoriul comunei Smârdan se întind pe o distanță de cca } \\
3,50 \mathrm{~km} \text {, iar întregul șir de tumuli are cca } 5,70 \mathrm{~km} \text {. }\end{array}$ & $\begin{array}{l}\text { La cca } 2 \mathrm{~km} \text { vest de } \\
\text { comună, pe versantul vestic } \\
\text { al văii Mălina. }\end{array}$ & $\begin{array}{l}\text { Brudiu 1991, 52; } \\
\text { Brudiu 2003, 93-136, } \\
\text { nr. } 195 .\end{array}$ \\
\hline
\end{tabular}




\begin{tabular}{|c|c|c|c|c|c|c|c|c|c|}
\hline $\begin{array}{l}\text { Nr. } \\
\text { crt. }\end{array}$ & Toponim & Administrativ & B & $\mathbf{C}$ & $\mathbf{F}$ & $\mathbf{T}$ & Descriere & Localizare & Bibliografie \\
\hline
\end{tabular}

\begin{tabular}{|c|c|c|c|c|c|c|c|c|c|}
\hline 284 & Neprecizat & $\begin{array}{l}\text { Smârdan (com.), } \\
\text { sat Smârdan }\end{array}$ & B & & $\mathbf{F}$ & $\mathbf{T}$ & $\begin{array}{l}\text { Dimensiuni: diam. } 30 \text { m, h. } 1,20 \text { m. Un șir de tumuli, nr. } 275-284 \text {, care } \\
\text { se continuă, pe teritoriul comunei Șendreni, cu nr. } 212-223 \text { și 489-490. } \\
\text { Cei } 10 \text { tumuli de pe teritoriul comunei Smârdan se întind pe o distanță de } \\
\text { cca } 3,50 \mathrm{~km} \text {, iar întregul șir de tumuli are cca } 5,70 \mathrm{~km} \text {. }\end{array}$ & $\begin{array}{l}\text { La cca } 2 \mathrm{~km} \text { vest de } \\
\text { comună, pe versantul vestic } \\
\text { al văii Mălina. }\end{array}$ & $\begin{array}{l}\text { Brudiu 2003, 93-136, } \\
\text { nr. } 395 .\end{array}$ \\
\hline 285 & Neprecizat & $\begin{array}{l}\text { Tulucești (com.), } \\
\text { sat Șivița }\end{array}$ & & $\mathbf{C}$ & $\mathbf{F}$ & & Face parte dintr-un șir de 8 tumuli (nr. 285, 287-293) & $\begin{array}{l}\text { Pe dealul Tătarca, în } \\
\text { punctul numit „La Ghilan”, } \\
\text { la } 4,40 \text { km nord-vest de } \\
\text { satul Șivița. }\end{array}$ & - \\
\hline 286 & Neprecizat & $\begin{array}{l}\text { Tulucessti (com.), } \\
\text { sat Șivița }\end{array}$ & & $\mathbf{C}$ & $\mathbf{F}$ & & - & $\begin{array}{l}\text { La } 2,60 \mathrm{~km} \text { vest de } \\
\text { localitatea Jidileni, pe } \\
\text { dealul Tătarca. }\end{array}$ & - \\
\hline 287 & Neprecizat & $\begin{array}{l}\text { Tulucești (com.), } \\
\text { sat Șivița }\end{array}$ & & & $\mathbf{F}$ & & Face parte dintr-un șir de 8 tumuli (nr. 285, 287-293) & $\begin{array}{l}\text { Pe dealul Tătarca, în } \\
\text { punctul numit „La Ghilan”, } \\
\text { la } 4,40 \text { km nord-vest de } \\
\text { satul Șivița. }\end{array}$ & - \\
\hline 288 & Neprecizat & $\begin{array}{l}\text { Tulucessti (com.), } \\
\text { sat Șivița }\end{array}$ & & & $\mathbf{F}$ & & Face parte dintr-un șir de 8 tumuli (nr. 285, 287-293) & $\begin{array}{l}\text { Pe dealul Tătarca, în } \\
\text { punctul numit „La Ghilan”, } \\
\text { la } 4,40 \text { km nord-vest de } \\
\text { satul Șivita. }\end{array}$ & - \\
\hline 289 & Neprecizat & $\begin{array}{l}\text { Tulucessti (com.), } \\
\text { sat Șivița }\end{array}$ & & & $\mathbf{F}$ & & Face parte dintr-un șir de 8 tumuli (nr. 285, 287-293) & $\begin{array}{l}\text { Pe dealul Tătarca, în } \\
\text { punctul numit „La Ghilan”, } \\
\text { la } 4,40 \text { km nord-vest de } \\
\text { satul Șivița. }\end{array}$ & - \\
\hline 290 & Neprecizat & $\begin{array}{l}\text { Tulucești (com.), } \\
\text { sat Șivița }\end{array}$ & & & $\mathbf{F}$ & & Face parte dintr-un șir de 8 tumuli (nr. 285, 287-293) & $\begin{array}{l}\text { Pe dealul Tătarca, în } \\
\text { punctul numit „La Ghilan”, } \\
\text { la } 4,40 \text { km nord-vest de } \\
\text { satul Șivița. }\end{array}$ & - \\
\hline 291 & Neprecizat & $\begin{array}{l}\text { Tulucești (com.), } \\
\text { sat Șivița }\end{array}$ & & & $\mathbf{F}$ & & Face parte dintr-un șir de 8 tumuli (nr. 285, 287-293) & $\begin{array}{l}\text { Pe dealul Tătarca, în } \\
\text { punctul numit „La Ghilan”, } \\
\text { la } 4,40 \text { km nord-vest de } \\
\text { satul Șivița. }\end{array}$ & - \\
\hline 292 & Neprecizat & $\begin{array}{l}\text { Tulucești (com.), } \\
\text { sat Șivița }\end{array}$ & & & $\mathbf{F}$ & & Face parte dintr-un șir de 8 tumuli (nr. 285, 287-293) & $\begin{array}{l}\text { Pe dealul Tătarca, în } \\
\text { punctul numit „La Ghilan”, } \\
\text { la } 4,40 \text { km nord-vest de } \\
\text { satul Șivița. }\end{array}$ & - \\
\hline 293 & Neprecizat & $\begin{array}{l}\text { Tulucești (com.) } \\
\text { sat Șivița }\end{array}$ & B & $\mathbf{C}$ & $\mathbf{F}$ & & $\begin{array}{l}\text { Dimensiuni: diam. } 40 \text { m, h. 1,20 m. Face parte dintr-un șir de } 8 \text { tumuli } \\
\text { (nr. 285, 287-293) }\end{array}$ & $\begin{array}{l}\text { Pe dealul Tătarca, în } \\
\text { punctul numit „La Ghilan”, } \\
\text { la } 4,40 \text { km nord-vest de } \\
\text { satul Șivița. }\end{array}$ & $\begin{array}{l}\text { Brudiu 1991, 54; } \\
\text { Brudiu 2003, 93-136, } \\
\text { nr. } 269 .\end{array}$ \\
\hline 294 & Neprecizat & $\begin{array}{l}\text { Tulucessti (com.), } \\
\text { sat Șivița }\end{array}$ & & $\mathbf{C}$ & $\mathbf{F}$ & & - & $\begin{array}{l}\text { La est de drumul Naţional } \\
\text { 24D, în dreptul localității } \\
\text { Şivița, la 2,50 km sud de nr. } \\
293 \text {. }\end{array}$ & - \\
\hline
\end{tabular}




\begin{tabular}{|c|c|c|c|c|c|c|c|c|c|}
\hline $\begin{array}{l}\text { Nr. } \\
\text { crt. }\end{array}$ & Toponim & Administrativ & B & $\mathbf{C}$ & $\mathbf{F}$ & $\mathbf{T}$ & Descriere & Localizare & Bibliografie \\
\hline
\end{tabular}

\begin{tabular}{|c|c|c|c|c|c|c|c|}
\hline 295 & Neprecizat & $\begin{array}{l}\text { Tulucești (com.), } \\
\text { sat Șivița }\end{array}$ & $\mathbf{C}$ & & - & $\begin{array}{l}\text { În partea de vest a localității } \\
\text { Şivița, într-o curte situată } \\
\text { între str. Prunilor și str. } \\
\text { Piersicilor. }\end{array}$ & - \\
\hline 296 & Neprecizat & $\begin{array}{l}\text { Tulucești (com.), } \\
\text { sat Tătarca }\end{array}$ & & $\mathbf{F}$ & Face parte dintr-un şir de 13 tumuli (nr. 296-308). & $\begin{array}{l}\text { La est de DN 24D, în } \\
\text { dreptul localității Tătarca, la } \\
1,30 \text { km nord de obârșia } \\
\text { văii Tărtăcuța. }\end{array}$ & - \\
\hline 297 & Neprecizat & $\begin{array}{l}\text { Tulucești (com.), } \\
\text { sat Tătarca }\end{array}$ & & $\mathbf{F}$ & Face parte dintr-un șir de 13 tumuli (nr. 296-308). & $\begin{array}{l}\text { La est de DN 24D, în } \\
\text { dreptul localității Tătarca, la } \\
1,30 \text { km nord de obârșia } \\
\text { văii Tărtăcuța. }\end{array}$ & - \\
\hline 298 & Neprecizat & $\begin{array}{l}\text { Tulucești (com.), } \\
\text { sat Tătarca }\end{array}$ & & $\mathbf{F}$ & Face parte dintr-un șir de 13 tumuli (nr. 296-308). & $\begin{array}{l}\text { La est de DN 24D, în } \\
\text { dreptul localității Tătarca, la } \\
1,25 \text { km nord de obârșia } \\
\text { văii Tărtăcuța. }\end{array}$ & - \\
\hline 299 & Neprecizat & $\begin{array}{l}\text { Tulucești (com.), } \\
\text { sat Tătarca }\end{array}$ & & $\mathbf{F}$ & Face parte dintr-un şir de 13 tumuli (nr. 296-308). & $\begin{array}{l}\text { La est de DN 24D, în } \\
\text { dreptul localității Tătarca, la } \\
1,20 \text { km nord de obârșia } \\
\text { văii Tărtăcuța. }\end{array}$ & - \\
\hline 300 & Neprecizat & $\begin{array}{l}\text { Tulucești (com.), } \\
\text { sat Tătarca }\end{array}$ & & $\mathbf{F}$ & Face parte dintr-un șir de 13 tumuli (nr. 296-308). & $\begin{array}{l}\text { La est de DN 24D, în } \\
\text { dreptul localității Tătarca, la } \\
1,15 \text { km nord de obârșia } \\
\text { văii Tărtăcuța. }\end{array}$ & - \\
\hline 301 & Neprecizat & $\begin{array}{l}\text { Tulucești (com.), } \\
\text { sat Tătarca }\end{array}$ & & $\mathbf{F}$ & Face parte dintr-un şir de 13 tumuli (nr. 296-308). & $\begin{array}{l}\text { La est de DN 24D, în } \\
\text { dreptul localității Tătarca, la } \\
1,10 \text { km nord de obârșia } \\
\text { văii Tărtăcuța. }\end{array}$ & - \\
\hline 302 & Neprecizat & $\begin{array}{l}\text { Tulucești (com.), } \\
\text { sat Tătarca }\end{array}$ & & $\mathbf{F}$ & Face parte dintr-un șir de 13 tumuli (nr. 296-308). & $\begin{array}{l}\text { La est de DN 24D, în } \\
\text { dreptul localității Tătarca, la } \\
1 \text { km nord de obârșia văii } \\
\text { Tărtăcuța. }\end{array}$ & - \\
\hline 303 & Neprecizat & $\begin{array}{l}\text { Tulucești (com.), } \\
\text { sat Tătarca }\end{array}$ & & $\mathbf{F}$ & Face parte dintr-un șir de 13 tumuli (nr. 296-308). & $\begin{array}{l}\text { La est de DN 24D, în } \\
\text { dreptul localității Tătarca, la } \\
950 \text { m nord de obârşia văii } \\
\text { Tărtăcuța. }\end{array}$ & - \\
\hline 304 & Neprecizat & $\begin{array}{l}\text { Tulucești (com.), } \\
\text { sat Tătarca }\end{array}$ & & $\mathbf{F}$ & Face parte dintr-un șir de 13 tumuli (nr. 296-308). & $\begin{array}{l}\text { La est de DN 24D, în } \\
\text { dreptul localității Tătarca, la } \\
900 \text { m nord de obârșia văii } \\
\text { Tărtăcuța. }\end{array}$ & - \\
\hline 305 & Neprecizat & $\begin{array}{l}\text { Tulucești (com.), } \\
\text { sat Tătarca }\end{array}$ & & $\mathbf{F}$ & Face parte dintr-un şir de 13 tumuli (nr. 296-308). & $\begin{array}{l}\text { La est de DN 24D, în } \\
\text { dreptul localității Tătarca, la } \\
850 \text { m nord de obârșia văii } \\
\text { Tărtăcuța. }\end{array}$ & - \\
\hline
\end{tabular}




\begin{tabular}{|c|c|c|c|c|c|c|c|c|c|}
\hline $\begin{array}{l}\text { Nr. } \\
\text { crt. }\end{array}$ & Toponim & Administrativ & B & C & $\mathbf{F}$ & $\mathbf{T}$ & Descriere & Localizare & Bibliografie \\
\hline
\end{tabular}

\begin{tabular}{|c|c|c|c|c|c|c|c|}
\hline 306 & Neprecizat & $\begin{array}{l}\text { Tulucești (com.), } \\
\text { sat Tătarca }\end{array}$ & $\mathbf{C}$ & $\mathbf{F}$ & Face parte dintr-un șir de 13 tumuli (nr. 296-308). & $\begin{array}{l}\text { La est de DN 24D, în } \\
\text { dreptul localității Tătarca, la } \\
800 \text { m nord de obârșia văii } \\
\text { Tărtăcuța. }\end{array}$ & - \\
\hline 307 & Neprecizat & $\begin{array}{l}\text { Tulucești (com.), } \\
\text { sat Tătarca }\end{array}$ & & $\mathbf{F}$ & Face parte dintr-un şir de 13 tumuli (nr. 296-308). & $\begin{array}{l}\text { La est de DN 24D, în } \\
\text { dreptul localității Tătarca, la } \\
400 \text { m nord de obârșia văii } \\
\text { Tărtăcuța. }\end{array}$ & - \\
\hline 308 & Neprecizat & $\begin{array}{l}\text { Tulucești (com.), } \\
\text { sat Tătarca }\end{array}$ & & $\mathbf{F}$ & Face parte dintr-un şir de 13 tumuli (nr. 296-308). & $\begin{array}{l}\text { La est de DN 24D, în } \\
\text { dreptul localității Tătarca, la } \\
250 \text { m nord de obârșia văii } \\
\text { Tărtăcuța. }\end{array}$ & - \\
\hline 309 & Neprecizat & $\begin{array}{l}\text { Tulucessti (com.), } \\
\text { sat Tulucești }\end{array}$ & $\mathbf{C}$ & $\mathbf{F}$ & - & $\begin{array}{l}\text { La est de DN 24D la 2,60 } \\
\text { km nord de intersecția } \\
\text { acestui drum cu „Valul lui } \\
\text { Traian”. }\end{array}$ & - \\
\hline 310 & Neprecizat & $\begin{array}{l}\text { Tulucessti (com.), } \\
\text { sat Tulucești }\end{array}$ & & $\mathbf{F}$ & - & $\begin{array}{l}\text { Pe dealul Târnăsoaiei, la } \\
\text { 5,50 km vest de Tuluceşti și } \\
\text { 3,80 km nord de Odaia } \\
\text { Manolache. }\end{array}$ & - \\
\hline 311 & Neprecizat & $\begin{array}{l}\text { Tuluceşti (com.), } \\
\text { sat Tulucești }\end{array}$ & $\mathbf{C}$ & $\mathbf{F}$ & - & $\begin{array}{l}\text { La } 100 \text { m vest de DN 24D } \\
\text { și } 600 \text { m nord de intersecția } \\
\text { drumului cu „Valul lui } \\
\text { Traian”. }\end{array}$ & - \\
\hline 312 & Neprecizat & $\begin{array}{l}\text { Tuluceşti (com.), } \\
\text { sat Tulucești }\end{array}$ & $\mathbf{C}$ & $\mathbf{F}$ & - & $\begin{array}{l}\text { La } 650 \text { m vest de DN 24D } \\
\text { și } 300 \text { m nord de intersecția } \\
\text { drumului cu „Valul lui } \\
\text { Traian”. }\end{array}$ & - \\
\hline 313 & Neprecizat & $\begin{array}{l}\text { Tulucessti (com.), } \\
\text { sat Tulucești }\end{array}$ & & $\mathbf{F}$ & - & $\begin{array}{l}\text { La } 800 \mathrm{~m} \text { vest de DN 24D } \\
\text { și } 200 \text { m nord de intersecția } \\
\text { drumului cu „Valul lui } \\
\text { Traian”. }\end{array}$ & - \\
\hline 314 & Neprecizat & $\begin{array}{l}\text { Tulucessti (com.), } \\
\text { sat Tulucești }\end{array}$ & & $\mathbf{F}$ & - & $\begin{array}{l}\text { La } 900 \text { m vest de DN 24D, } \\
\text { pe „Valul lui Traian”. }\end{array}$ & - \\
\hline 315 & Neprecizat & $\begin{array}{l}\text { Tulucessti (com.), } \\
\text { sat Tulucești }\end{array}$ & & $\mathbf{F}$ & - & $\begin{array}{l}\text { La } 1,40 \mathrm{~km} \text { nord-est de } \\
\text { localitatea Odaia M. şi la } \\
400 \mathrm{~m} \text { sud de „Valul lui } \\
\text { Traian”. }\end{array}$ & - \\
\hline 316 & Neprecizat & $\begin{array}{l}\text { Tulucessti (com.), } \\
\text { sat Tulucești }\end{array}$ & & $\mathbf{F}$ & - & $\begin{array}{l}\text { La } 600 \text { m vest de DN 24D } \\
\text { și } 1 \mathrm{~km} \text { sud de intersecția } \\
\text { drumului cu „Valul lui } \\
\text { Traian”. }\end{array}$ & - \\
\hline
\end{tabular}




\begin{tabular}{|c|c|c|c|c|c|c|c|c|c|}
\hline $\begin{array}{l}\text { Nr. } \\
\text { crt. }\end{array}$ & Toponim & Administrativ & B & C & $\mathbf{F}$ & $\mathbf{T}$ & Descriere & Localizare & Bibliografie \\
\hline
\end{tabular}

\begin{tabular}{|c|c|c|c|c|c|c|}
\hline 317 & Neprecizat & $\begin{array}{l}\text { Tulucești (com.), } \\
\text { sat Tulucești }\end{array}$ & $\mathbf{F}$ & - & $\begin{array}{l}\text { La } 500 \mathrm{~m} \text { vest de DN 24D } \\
\text { și } 1,30 \mathrm{~km} \text { sud de intersecția } \\
\text { drumului cu „Valul lui } \\
\text { Traian”. }\end{array}$ & - \\
\hline 318 & Neprecizat & $\begin{array}{l}\text { Tulucești (com.), } \\
\text { sat Tulucești }\end{array}$ & $\mathbf{F}$ & - & $\begin{array}{l}\text { La } 800 \mathrm{~m} \text { vest de DN 24D } \\
\text { și } 1,50 \mathrm{~km} \text { sud de intersecția } \\
\text { drumului cu „Valul lui } \\
\text { Traian”. }\end{array}$ & - \\
\hline 319 & Neprecizat & $\begin{array}{l}\text { Tulucești (com.), } \\
\text { sat Tulucești }\end{array}$ & $\mathbf{F}$ & - & $\begin{array}{l}\text { La } 750 \text { m vest de DN 24D } \\
\text { și } 1,60 \mathrm{~km} \text { sud de intersecția } \\
\text { drumului cu „Valul lui } \\
\text { Traian”. }\end{array}$ & - \\
\hline 320 & Neprecizat & $\begin{array}{l}\text { Tuluceşti (com.), } \\
\text { sat Tulucești }\end{array}$ & $\mathbf{F}$ & - & $\begin{array}{l}\text { La } 600 \mathrm{~m} \text { vest de DN 24D } \\
\text { și } 1,60 \mathrm{~km} \text { sud de intersecția } \\
\text { drumului cu „Valul lui } \\
\text { Traian”. }\end{array}$ & - \\
\hline 321 & Neprecizat & $\begin{array}{l}\text { Tulucești (com.), } \\
\text { sat Tulucești }\end{array}$ & $\mathbf{F}$ & - & $\begin{array}{l}\text { La } 1 \text { km vest de DN 24D și } \\
2 \text { km sud de intersecția } \\
\text { drumului cu „Valul lui } \\
\text { Traian”. }\end{array}$ & - \\
\hline 322 & Neprecizat & $\begin{array}{l}\text { Tulucești (com.), } \\
\text { sat Tulucești }\end{array}$ & $\mathbf{F}$ & - & $\begin{array}{l}\text { Pe un interfluviu între văile } \\
\text { Părului și Lanul Lung, la } 1 \\
\text { km est de satul Odaia } \\
\text { Manolache. }\end{array}$ & - \\
\hline 323 & Neprecizat & $\begin{array}{l}\text { Tulucești (com.), } \\
\text { sat Tulucești }\end{array}$ & $\mathbf{F}$ & - & $\begin{array}{l}\text { Pe un interfluviu între văile } \\
\text { Părului și Lanul Lung, la } 1 \\
\text { km est de satul Odaia } \\
\text { Manolache. La } 50 \text { m sud de } \\
\text { nr. } 322 .\end{array}$ & - \\
\hline 324 & Neprecizat & $\begin{array}{l}\text { Tulucești (com.), } \\
\text { sat Tulucești }\end{array}$ & $\mathbf{F}$ & - & $\begin{array}{l}\text { Pe un interfluviu între văile } \\
\text { Părului și Lanul Lung, la } 1 \\
\text { km est de satul Odaia } \\
\text { Manolache. La } 100 \text { m sud } \\
\text { de nr. } 323 \text {. }\end{array}$ & - \\
\hline 325 & Neprecizat & $\begin{array}{l}\text { Tulucești (com.), } \\
\text { sat Tulucești }\end{array}$ & $\mathbf{F}$ & - & $\begin{array}{l}\text { Pe un interfluviu între văile } \\
\text { Părului și Lanul Lung, la } 1 \\
\text { km est de satul Odaia } \\
\text { Manolache. La } 100 \text { m sud } \\
\text { de nr. 324. }\end{array}$ & - \\
\hline 326 & Neprecizat & $\begin{array}{l}\text { Tulucești (com.), } \\
\text { sat Tulucești }\end{array}$ & $\mathbf{F}$ & - & $\begin{array}{l}\text { Pe un interfluviu între văile } \\
\text { Părului și Lanul Lung, la } 1 \\
\text { km est de satul Odaia } \\
\text { Manolache. La } 50 \text { m sud- } \\
\text { vest de nr. } 325 .\end{array}$ & - \\
\hline
\end{tabular}




\begin{tabular}{|c|c|c|c|c|c|c|c|c|c|}
\hline $\begin{array}{l}\text { Nr. } \\
\text { crt. }\end{array}$ & Toponim & Administrativ & B & $\mathbf{C}$ & $\mathbf{F}$ & $\mathbf{T}$ & Descriere & Localizare & Bibliografie \\
\hline
\end{tabular}

\begin{tabular}{|c|c|c|c|c|c|c|c|}
\hline 327 & Neprecizat & $\begin{array}{l}\text { Tulucești (com.), } \\
\text { sat Tulucești }\end{array}$ & & $\mathbf{F}$ & - & $\begin{array}{l}\text { Pe un interfluviu între văile } \\
\text { Părului şi Lanul Lung, la } 1 \\
\text { km est de satul Odaia } \\
\text { Manolache. La } 50 \text { m sud de } \\
\text { nr. } 326 .\end{array}$ & - \\
\hline 328 & $\begin{array}{c}\text { Movila } \\
\text { Odaia } \\
\text { Manolache }\end{array}$ & $\begin{array}{l}\text { Vânători (com.), } \\
\text { sat Odaia } \\
\text { Manolache }\end{array}$ & $\mathbf{B}$ & $\mathbf{F}$ & Dimensiuni: diam. 45 m, h. 2 m. & $\begin{array}{l}\text { La } 850 \mathrm{~m} \text { est de satul O. } \\
\text { Manolache, la nord de } \\
\text { șosea. }\end{array}$ & $\begin{array}{l}\text { Brudiu 1991, 53, nr. } \\
\text { 221; Brudiu 2003, } 93- \\
\text { 136, nr. } 221 .\end{array}$ \\
\hline 329 & Neprecizat & $\begin{array}{l}\text { Tulucești (com.), } \\
\text { sat Tulucești }\end{array}$ & & $\mathbf{F}$ & Face parte dintr-un grup de 8 tumuli . & $\begin{array}{l}\text { La cca 1,80-2,20 km est de } \\
\text { satul Odaia Manolache } \\
\text { aproape de obârșia Văii } \\
\text { Părului. }\end{array}$ & 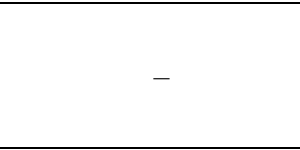 \\
\hline 330 & Neprecizat & $\begin{array}{l}\text { Tulucești (com.), } \\
\text { sat Tulucești }\end{array}$ & & $\mathbf{F}$ & Face parte dintr-un grup de 8 tumuli . & $\begin{array}{l}\text { La cca 1,80-2,20 km est de } \\
\text { satul Odaia Manolache } \\
\text { aproape de obârșia Văii } \\
\text { Părului. }\end{array}$ & - \\
\hline 331 & Neprecizat & $\begin{array}{l}\text { Tulucești (com.), } \\
\text { sat Tulucești }\end{array}$ & & $\mathbf{F}$ & Face parte dintr-un grup de 8 tumuli . & $\begin{array}{l}\text { La cca 1,80-2,20 km est de } \\
\text { satul Odaia Manolache } \\
\text { aproape de obârșia Văii } \\
\text { Părului. }\end{array}$ & - \\
\hline 332 & Neprecizat & $\begin{array}{l}\text { Tulucești (com.), } \\
\text { sat Tulucești }\end{array}$ & & $\mathbf{F}$ & Face parte dintr-un grup de 8 tumuli. & $\begin{array}{l}\text { La cca 1,80-2,20 km est de } \\
\text { satul Odaia Manolache } \\
\text { aproape de obârșia Văii } \\
\text { Părului. }\end{array}$ & - \\
\hline 333 & Neprecizat & $\begin{array}{l}\text { Tulucești (com.), } \\
\text { sat Tulucești }\end{array}$ & & $\mathbf{F}$ & Face parte dintr-un grup de 8 tumuli & $\begin{array}{l}\text { La cca 1,80-2,20 km est de } \\
\text { satul Odaia Manolache } \\
\text { aproape de obârșia Văii } \\
\text { Părului. }\end{array}$ & - \\
\hline 334 & Neprecizat & $\begin{array}{l}\text { Tuluceşti (com.), } \\
\text { sat Tulucești }\end{array}$ & & $\mathbf{F}$ & Face parte dintr-un grup de 8 tumuli . & $\begin{array}{l}\text { La cca 1,80-2,20 km est de } \\
\text { satul Odaia Manolache } \\
\text { aproape de obârşia Văii } \\
\text { Părului. }\end{array}$ & - \\
\hline 335 & Neprecizat & $\begin{array}{l}\text { Tuluceşti (com.), } \\
\text { sat Tulucești }\end{array}$ & & $\mathbf{F}$ & Face parte dintr-un grup de 8 tumuli . & $\begin{array}{l}\text { La cca 1,80-2,20 km est de } \\
\text { satul Odaia Manolache } \\
\text { aproape de obârșia Văii } \\
\text { Părului. }\end{array}$ & - \\
\hline 336 & Neprecizat & $\begin{array}{l}\text { Tulucești (com.), } \\
\text { sat Tulucești }\end{array}$ & $\mathbf{B}$ & $\mathbf{F}$ & Dimensiuni: diam. 22 m, h. 1,10 m. & $\begin{array}{l}\text { La } 560 \text { m sud de Movila } \\
\text { Morilor Bacalbaşa (nr. } \\
\text { 346). }\end{array}$ & $\begin{array}{l}\text { Brudiu 1991, 54, nr. } \\
\text { 263; Brudiu 2003, } 93- \\
\text { 136, nr. } 263 .\end{array}$ \\
\hline 337 & Neprecizat & $\begin{array}{l}\text { Tuluceşti (com.), } \\
\text { sat Tulucești }\end{array}$ & & $\mathbf{F}$ & Face parte dintr-un grup de 8 tumuli . & $\begin{array}{l}\text { La cca 1,80-2,20 km est de } \\
\text { satul Odaia Manolache } \\
\text { aproape de obârșia Văii } \\
\text { Părului. }\end{array}$ & - \\
\hline
\end{tabular}




\begin{tabular}{|c|c|c|c|c|c|c|c|c|c|}
\hline $\begin{array}{l}\text { Nr. } \\
\text { crt. }\end{array}$ & Toponim & Administrativ & B & $\mathbf{C}$ & $\mathbf{F}$ & $\mathbf{T}$ & Descriere & Localizare & Bibliografie \\
\hline
\end{tabular}

\begin{tabular}{|c|c|c|c|c|c|c|c|c|}
\hline 338 & $\begin{array}{l}\text { Movila de la } \\
\text { Nicolae } \\
\text { Țocu }\end{array}$ & $\begin{array}{l}\text { Vânători (com.), } \\
\text { sat Vânători }\end{array}$ & B & & $\mathbf{F}$ & $\begin{array}{l}\text { Cercetat în } 1981 \text { de către Brudiu, printr-o săpătură preventivă în cadrul } \\
\text { lucrărilor de construcție a sistemului de irigații din câmpia Covurluiului. } \\
\text { Dimensiunile tumulilor sunt } 3 \text { m în înălțime și } 60 \text { m diametru. Au fost } \\
\text { descoperite } 14 \text { morminte de inhumație, astfel: } 3 \text { morminte din perioada } \\
\text { de tranziție de la eneolitic la epoca bronzului, } 7 \text { morminte din perioada } \\
\text { mijlocie a epocii bronzului și } 4 \text { morminte din epoca migrațiilor. Cele trei } \\
\text { morminte din epoca de tranziție conțineau urme de ocru, iar din inventar } \\
\text { se evidențiază un inel de argint în formă de spirală și un vas miniatural, } \\
\text { ovoidal (material specific culturii Iamnaia din zona Niprului). }\end{array}$ & $\begin{array}{l}\text { Se află la } 1 \mathrm{~km} \text { nord de } \\
\text { comună. }\end{array}$ & $\begin{array}{l}\text { Brudiu 1985, 235-248; } \\
\text { Brudiu 1991, 53, nr. } \\
\text { 222; Brudiu 2003, 54, } \\
\text { 93-136, nr. 222. }\end{array}$ \\
\hline 339 & Neprecizat & $\begin{array}{l}\text { Tulucești (com.), } \\
\text { sat Tulucești }\end{array}$ & & & $\mathbf{F}$ & Dimensiuni: diam. 30 m, h. 1 m. & $\begin{array}{l}\text { La } 300 \mathrm{~m} \text { est de DN 24D și } \\
\text { la } 1,40 \mathrm{~km} \text { nord de } \\
\text { intersecția acestuia cu DN } \\
26 .\end{array}$ & $\begin{array}{l}\text { Brudiu 1991, 54, nr. } \\
\text { 269; Brudiu 2003, 93- } \\
\text { 136, nr. } 269 .\end{array}$ \\
\hline 340 & Neprecizat & $\begin{array}{l}\text { Tuluceşti (com.), } \\
\text { sat Tulucești }\end{array}$ & & & $\mathbf{F}$ & - & La 100 m est de nr. 339. & - \\
\hline 341 & Neprecizat & $\begin{array}{l}\text { Tulucești (com.), } \\
\text { sat Tulucești }\end{array}$ & B & & $\mathbf{F}$ & Dimensiuni: diam. 35 m, h. 1 m. & La 100 m sud de nr. 339. & $\begin{array}{l}\text { Brudiu 1991, 54, nr. } \\
\text { 268; Brudiu 2003, 93- } \\
\text { 136, nr. } 268 .\end{array}$ \\
\hline 342 & Neprecizat & $\begin{array}{l}\text { Tuluceşti (com.), } \\
\text { sat Tulucești }\end{array}$ & B & & $\mathbf{F}$ & Dimensiuni: diam. 18 m, h. 0,90 m. & La $50 \mathrm{~m}$ sud de nr. 341. & $\begin{array}{l}\text { Brudiu 1991, 54, nr. } \\
\text { 266; Brudiu 2003, 93- } \\
\text { 136, nr. } 266 .\end{array}$ \\
\hline 343 & Neprecizat & $\begin{array}{l}\text { Tulucești (com.), } \\
\text { sat Tulucești }\end{array}$ & B & & $\mathbf{F}$ & Dimensiuni: diam. 40 m, h. 1,20 m. & $\begin{array}{l}\text { La } 200 \text { m sud-vest de nr. } \\
342 .\end{array}$ & $\begin{array}{l}\text { Brudiu 1991, 54, nr. } \\
\text { 265; Brudiu 2003, 93- } \\
\text { 136, nr. } 265 .\end{array}$ \\
\hline 344 & Neprecizat & $\begin{array}{l}\text { Tuluceşti (com.), } \\
\text { sat Tulucești }\end{array}$ & & & $\mathbf{F}$ & - & $\begin{array}{l}\text { La } 120 \text { m sud-est de nr. } \\
343 .\end{array}$ & - \\
\hline 345 & Neprecizat & $\begin{array}{l}\text { Tulucești (com.), } \\
\text { sat Tulucești }\end{array}$ & B & $\mathbf{C}$ & $\mathbf{F}$ & Dimensiuni: diam. 40 m, h. 1,1 m. & $\begin{array}{l}\text { La } 300 \mathrm{~m} \text { sud de nr. } 344 \text { și } \\
\text { la } 80 \text { m est de drumul DN } \\
\text { 24D. }\end{array}$ & $\begin{array}{l}\text { Brudiu 1991, 54, nr. } \\
\text { 264; Brudiu 2003, 93- } \\
\text { 136, nr. } 264 .\end{array}$ \\
\hline 346 & $\begin{array}{l}\text { Movila } \\
\text { Morile } \\
\text { Bacalbașa }\end{array}$ & $\begin{array}{l}\text { Tulucești (com.), } \\
\text { sat Tulucești }\end{array}$ & B & c & & Dimensiuni: diam. 80 m, h. 6 m. & $\begin{array}{l}\text { La intersecția șoselelor } \\
\text { Galați-Tulucești și Galați- } \\
\text { Cuca. }\end{array}$ & $\begin{array}{l}\text { Brudiu 1991, 53, nr. } \\
\text { 220; Brudiu 2003, } 93- \\
\text { 136, nr. } 220 .\end{array}$ \\
\hline 347 & $\begin{array}{l}\text { Movila lui } \\
\text { Amelian } \\
\text { Chirilă }\end{array}$ & $\begin{array}{l}\text { Tulucești (com.), } \\
\text { sat Tulucești }\end{array}$ & B & & $\mathbf{F}$ & Dimensiuni: diam. 40 m, h. 7 m. & $\begin{array}{l}\text { În dreapta DN } 26 \text { Vânători- } \\
\text { Tuluceşti, la aproximativ } \\
100 \text { m spre est, la } 1 \text { km sud } \\
\text { de localitate. }\end{array}$ & Croitoru 2013, 165. \\
\hline 348 & Neprecizat & $\begin{array}{l}\text { Vânători (com.), } \\
\text { sat Odaia } \\
\text { Manolache }\end{array}$ & B & & & Dimensiuni: diam. 50 m, h. 2 m. & $\begin{array}{l}\text { La } 1,40 \text { km sud de satul } \\
\text { Odaia Manolache și la } 1,80 \\
\text { km vest de Vânători, intrată } \\
\text { în componența cătunului } \\
\text { Slobozia Tumulii. }\end{array}$ & $\begin{array}{l}\text { Brudiu 1991, 51, nr. } \\
\text { 160; Brudiu 2003, } 93- \\
\text { 136, nr. } 160 .\end{array}$ \\
\hline 349 & Neprecizat & $\begin{array}{l}\text { Vânători (com.), } \\
\text { sat Odaia } \\
\text { Manolache } \\
\end{array}$ & & & $\mathbf{F}$ & - & La $250 \mathrm{~m}$ sud de nr. 349. & - \\
\hline
\end{tabular}




\begin{tabular}{|c|c|c|c|c|c|c|c|c|c|}
\hline $\begin{array}{l}\text { Nr. } \\
\text { crt. }\end{array}$ & Toponim & Administrativ & B & $\mathbf{C}$ & $\mathbf{F}$ & $\mathbf{T}$ & Descriere & Localizare & Bibliografie \\
\hline
\end{tabular}

\begin{tabular}{|c|c|c|c|c|c|c|c|c|c|}
\hline 350 & Neprecizat & $\begin{array}{l}\text { Vânători (com.), } \\
\text { sat Odaia } \\
\text { Manolache }\end{array}$ & & $\mathbf{C}$ & & & - & $\begin{array}{l}\text { La } 200 \mathrm{~km} \text { est de DN } 26 \\
\text { aproape de intrarea în satul } \\
\text { Vânători. }\end{array}$ & - \\
\hline 351 & Neprecizat & $\begin{array}{l}\text { Vânători (com.), } \\
\text { sat Odaia } \\
\text { Manolache }\end{array}$ & & & $\mathbf{F}$ & & - & $\begin{array}{l}\text { În partea de sud-est a } \\
\text { localității Vânători, la } 365 \\
\text { m vest de DN } 26 .\end{array}$ & - \\
\hline 352 & $\begin{array}{l}\text { Movila } \\
\text { Lungă }\end{array}$ & $\begin{array}{l}\text { Vânători (com.), } \\
\text { sat Vânători }\end{array}$ & B & $\mathbf{C}$ & & & Dimensiuni: diam. 60 m, h. 2 m. & $\begin{array}{l}\text { În partea de est a comunei, } \\
\text { intravilan. }\end{array}$ & $\begin{array}{l}\text { Brudiu 1991, 53; nr. } \\
\text { 223; Brudiu 2003, 93- } \\
\text { 136, nr. 223. }\end{array}$ \\
\hline 353 & Neprecizat & $\begin{array}{l}\text { Vânători (com.), } \\
\text { sat Vânători }\end{array}$ & B & & & & $\begin{array}{l}\text { Dimensiuni: diam. } 40 \text { m, h. } 1,50 \text { m. Un sfert de movilă se mai păstrează } \\
\text { în grădina locuitorului Palade Constantin. 3/4 din movilă au fost distruse } \\
\text { în } 1982 \text {. }\end{array}$ & $\begin{array}{l}\text { La sud-est de localitate şi la } \\
70 \text { m est de şoseaua Galaţi- } \\
\text { Tulucești. }\end{array}$ & $\begin{array}{l}\text { Brudiu 1991, 53, nr. } \\
\text { 224; Brudiu 2003, 93- } \\
\text { 136, nr. } 224 .\end{array}$ \\
\hline 354 & Neprecizat & $\begin{array}{l}\text { Vânători (com.), } \\
\text { sat Vânători }\end{array}$ & B & & & & Dimensiuni: diam. 25 m, h. 0,60 m. & $\begin{array}{l}\text { Între șoseaua Galați- } \\
\text { Tulucești și faleza } \\
\text { Brateşului la } 100 \text { m sud nr. } \\
353 \text {. }\end{array}$ & $\begin{array}{l}\text { Brudiu 1991, 53, nr. } \\
\text { 226; Brudiu 2003, } 93- \\
\text { 136, nr. } 226 .\end{array}$ \\
\hline 355 & Neprecizat & $\begin{array}{l}\text { Vânători (com.), } \\
\text { sat Vânători }\end{array}$ & B & & & & Dimensiuni: diam. 60 m, h. 2 m. & $\begin{array}{l}\text { La km } 9 \text { pe şoseaua Galați- } \\
\text { Tulucești. }\end{array}$ & $\begin{array}{l}\text { Brudiu 1991, 53, nr. } \\
\text { 229; Brudiu 2003, } 93- \\
\text { 136, nr. } 229 .\end{array}$ \\
\hline 356 & Neprecizat & $\begin{array}{l}\text { Vânători (com.), } \\
\text { sat Vânători }\end{array}$ & & & $\mathbf{F}$ & & - & $\begin{array}{l}\text { La } 2,70 \mathrm{~km} \text { sud-vest de } \\
\text { localitate. }\end{array}$ & 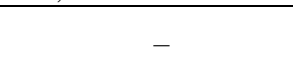 \\
\hline 357 & Neprecizat & $\begin{array}{l}\text { Vânători (com.), } \\
\text { sat Vânători }\end{array}$ & & & $\mathbf{F}$ & & - & La $450 \mathrm{~m}$ sud de nr. 355. & - \\
\hline 358 & Neprecizat & $\begin{array}{l}\text { Vânători (com.), } \\
\text { sat Vânători }\end{array}$ & & & $\mathbf{F}$ & & - & $\begin{array}{l}\text { La 4,50 km sud-vest de } \\
\text { Vânători, aproape de Valea } \\
\text { lui Manolache. }\end{array}$ & - \\
\hline 359 & Neprecizat & $\begin{array}{l}\text { Vânători (com.), } \\
\text { sat Vânători }\end{array}$ & & & $\mathbf{F}$ & & - & La 400 m sud de nr. 357. & - \\
\hline 360 & Neprecizat & $\begin{array}{l}\text { Vânători (com.), } \\
\text { sat Costi }\end{array}$ & & & $\mathbf{F}$ & $\mathbf{T}$ & Face parte dintr-un grup de 27 de tumuli. & $\begin{array}{l}\text { Grupul se află situat la } 4,50 \\
\text { km nord-vest de satul Costi, } \\
\text { pe un platou situat la est de } \\
\text { Valea lui Manolache. }\end{array}$ & - \\
\hline 361 & Neprecizat & $\begin{array}{l}\text { Vânători (com.), } \\
\text { sat Costi }\end{array}$ & & & $\mathbf{F}$ & $\mathbf{T}$ & Face parte dintr-un grup de 27 de tumuli. & $\begin{array}{l}\text { Grupul se află situat la } 4,50 \\
\text { km nord-vest de satul Costi, } \\
\text { pe un platou situat la est de } \\
\text { Valea lui Manolache. }\end{array}$ & - \\
\hline 362 & Neprecizat & $\begin{array}{l}\text { Vânători (com.), } \\
\text { sat Costi }\end{array}$ & & & $\mathbf{F}$ & $\mathbf{T}$ & Face parte dintr-un grup de 27 de tumuli. & $\begin{array}{l}\text { Grupul se află situat la } 4,50 \\
\text { km nord-vest de satul Costi, } \\
\text { pe un platou situat la est de } \\
\text { Valea lui Manolache. }\end{array}$ & - \\
\hline 363 & Neprecizat & $\begin{array}{l}\text { Vânători (com.), } \\
\text { sat Costi }\end{array}$ & & & $\mathbf{F}$ & $\mathbf{T}$ & Face parte dintr-un grup de 27 de tumuli. & $\begin{array}{l}\text { Grupul se află situat la } 4,50 \\
\text { km nord-vest de satul Costi, } \\
\text { pe un platou situat la est de } \\
\text { Valea lui Manolache. }\end{array}$ & - \\
\hline
\end{tabular}




\begin{tabular}{|l|l|l|l|l|l|l|l|c|c|}
\hline $\begin{array}{l}\text { Nr. } \\
\text { crt. }\end{array}$ & Toponim & Administrativ & B & C & F & T & Descriere & Localizare & Bibliografie \\
\hline
\end{tabular}

\begin{tabular}{|c|c|c|c|c|c|c|c|}
\hline 364 & Neprecizat & $\begin{array}{l}\text { Vânători (com.), } \\
\text { sat Costi }\end{array}$ & $\mathbf{F}$ & $\mathbf{T}$ & Face parte dintr-un grup de 27 de tumuli. & $\begin{array}{l}\text { Grupul se affă situat la 4,50 } \\
\text { km nord-vest de satul Costi, } \\
\text { pe un platou situat la est de } \\
\text { Valea lui Manolache. }\end{array}$ & - \\
\hline 365 & Neprecizat & $\begin{array}{l}\text { Vânători (com.), } \\
\text { sat Costi }\end{array}$ & $\mathbf{F}$ & $\mathbf{T}$ & Face parte dintr-un grup de 27 de tumuli. & $\begin{array}{l}\text { Grupul se află situat la 4,50 } \\
\text { km nord-vest de satul Costi, } \\
\text { pe un platou situat la est de } \\
\text { Valea lui Manolache. }\end{array}$ & - \\
\hline 366 & Neprecizat & $\begin{array}{l}\text { Vânători (com.), } \\
\text { sat Costi }\end{array}$ & $\mathbf{F}$ & $\mathbf{T}$ & Face parte dintr-un grup de 27 de tumuli. & $\begin{array}{l}\text { Grupul se află situat la } 4,50 \\
\text { km nord-vest de satul Costi, } \\
\text { pe un platou situat la est de } \\
\text { Valea lui Manolache. }\end{array}$ & - \\
\hline 367 & Neprecizat & $\begin{array}{l}\text { Vânători (com.), } \\
\text { sat Costi }\end{array}$ & $\mathbf{F}$ & $\mathbf{T}$ & Face parte dintr-un grup de 27 de tumuli. & $\begin{array}{l}\text { Grupul se află situat la } 4,50 \\
\text { km nord-vest de satul Costi, } \\
\text { pe un platou situat la est de } \\
\text { Valea lui Manolache. }\end{array}$ & - \\
\hline 368 & Neprecizat & $\begin{array}{l}\text { Vânători (com.), } \\
\text { sat Costi }\end{array}$ & $\mathbf{F}$ & $\mathbf{T}$ & Face parte dintr-un grup de 27 de tumuli. & $\begin{array}{l}\text { Grupul se află situat la 4,50 } \\
\text { km nord-vest de satul Costi, } \\
\text { pe un platou situat la est de } \\
\text { Valea lui Manolache. }\end{array}$ & - \\
\hline 369 & Neprecizat & $\begin{array}{l}\text { Vânători (com.), } \\
\text { sat Costi }\end{array}$ & $\mathbf{F}$ & $\mathbf{T}$ & Face parte dintr-un grup de 27 de tumuli. & $\begin{array}{l}\text { Grupul se affă situat la } 4,50 \\
\text { km nord-vest de satul Costi, } \\
\text { pe un platou situat la est de } \\
\text { Valea lui Manolache. }\end{array}$ & - \\
\hline 370 & Neprecizat & $\begin{array}{l}\text { Vânători (com.), } \\
\text { sat Costi }\end{array}$ & $\mathbf{F}$ & $\mathbf{T}$ & Face parte dintr-un grup de 27 de tumuli. & $\begin{array}{l}\text { Grupul se află situat la } 4,50 \\
\text { km nord-vest de satul Costi, } \\
\text { pe un platou situat la est de } \\
\text { Valea lui Manolache. }\end{array}$ & - \\
\hline 371 & Neprecizat & $\begin{array}{l}\text { Vânători (com.), } \\
\text { sat Costi }\end{array}$ & $\mathbf{F}$ & $\mathbf{T}$ & Face parte dintr-un grup de 27 de tumuli. & $\begin{array}{l}\text { Grupul se affă situat la 4,50 } \\
\text { km nord-vest de satul Costi, } \\
\text { pe un platou situat la est de } \\
\text { Valea lui Manolache. }\end{array}$ & - \\
\hline 372 & Neprecizat & $\begin{array}{l}\text { Vânători (com.), } \\
\text { sat Costi }\end{array}$ & $\mathbf{F}$ & $\mathbf{T}$ & Face parte dintr-un grup de 27 de tumuli. & $\begin{array}{l}\text { Grupul se află situat la 4,50 } \\
\text { km nord-vest de satul Costi, } \\
\text { pe un platou situat la est de } \\
\text { Valea lui Manolache. }\end{array}$ & - \\
\hline 373 & Neprecizat & $\begin{array}{l}\text { Vânători (com.), } \\
\text { sat Costi }\end{array}$ & $\mathbf{F}$ & $\mathbf{T}$ & Face parte dintr-un grup de 27 de tumuli. & $\begin{array}{l}\text { Grupul se află situat la 4,50 } \\
\text { km nord-vest de satul Costi, } \\
\text { pe un platou situat la est de } \\
\text { Valea lui Manolache. }\end{array}$ & - \\
\hline 374 & Neprecizat & $\begin{array}{l}\text { Vânători (com.), } \\
\text { sat Costi }\end{array}$ & $\mathbf{F}$ & $\mathbf{T}$ & Face parte dintr-un grup de 27 de tumuli. & $\begin{array}{l}\text { Grupul se află situat la 4,50 } \\
\text { km nord-vest de satul Costi, } \\
\text { pe un platou situat la est de } \\
\text { Valea lui Manolache. }\end{array}$ & - \\
\hline
\end{tabular}




\begin{tabular}{|l|l|l|l|l|l|l|l|c|c|}
\hline $\begin{array}{l}\text { Nr. } \\
\text { crt. }\end{array}$ & Toponim & Administrativ & B & C & F & T & Descriere & Localizare & Bibliografie \\
\hline
\end{tabular}

\begin{tabular}{|c|c|c|c|c|c|c|c|}
\hline 375 & Neprecizat & $\begin{array}{l}\text { Vânători (com.), } \\
\text { sat Costi }\end{array}$ & $\mathbf{F}$ & $\mathbf{T}$ & Face parte dintr-un grup de 27 de tumuli. & $\begin{array}{l}\text { Grupul se affă situat la 4,50 } \\
\text { km nord-vest de satul Costi, } \\
\text { pe un platou situat la est de } \\
\text { Valea lui Manolache. }\end{array}$ & - \\
\hline 376 & Neprecizat & $\begin{array}{l}\text { Vânători (com.), } \\
\text { sat Costi }\end{array}$ & $\mathbf{F}$ & $\mathbf{T}$ & Face parte dintr-un grup de 27 de tumuli. & $\begin{array}{l}\text { Grupul se află situat la 4,50 } \\
\text { km nord-vest de satul Costi, } \\
\text { pe un platou situat la est de } \\
\text { Valea lui Manolache. }\end{array}$ & - \\
\hline 377 & Neprecizat & $\begin{array}{l}\text { Vânători (com.), } \\
\text { sat Costi }\end{array}$ & $\mathbf{F}$ & $\mathbf{T}$ & Face parte dintr-un grup de 27 de tumuli. & $\begin{array}{l}\text { Grupul se află situat la } 4,50 \\
\text { km nord-vest de satul Costi, } \\
\text { pe un platou situat la est de } \\
\text { Valea lui Manolache. }\end{array}$ & - \\
\hline 378 & Neprecizat & $\begin{array}{l}\text { Vânători (com.), } \\
\text { sat Costi }\end{array}$ & $\mathbf{F}$ & $\mathbf{T}$ & Face parte dintr-un grup de 27 de tumuli. & $\begin{array}{l}\text { Grupul se află situat la } 4,50 \\
\text { km nord-vest de satul Costi, } \\
\text { pe un platou situat la est de } \\
\text { Valea lui Manolache. }\end{array}$ & - \\
\hline 379 & Neprecizat & $\begin{array}{l}\text { Vânători (com.), } \\
\text { sat Costi }\end{array}$ & $\mathbf{F}$ & $\mathbf{T}$ & Face parte dintr-un grup de 27 de tumuli. & $\begin{array}{l}\text { Grupul se află situat la 4,50 } \\
\text { km nord-vest de satul Costi, } \\
\text { pe un platou situat la est de } \\
\text { Valea lui Manolache. }\end{array}$ & - \\
\hline 380 & Neprecizat & $\begin{array}{l}\text { Vânători (com.), } \\
\text { sat Costi }\end{array}$ & $\mathbf{F}$ & $\mathbf{T}$ & Face parte dintr-un grup de 27 de tumuli. & $\begin{array}{l}\text { Grupul se affă situat la } 4,50 \\
\text { km nord-vest de satul Costi, } \\
\text { pe un platou situat la est de } \\
\text { Valea lui Manolache. }\end{array}$ & - \\
\hline 381 & Neprecizat & $\begin{array}{l}\text { Vânători (com.), } \\
\text { sat Costi }\end{array}$ & $\mathbf{F}$ & $\mathbf{T}$ & Face parte dintr-un grup de 27 de tumuli. & $\begin{array}{l}\text { Grupul se află situat la } 4,50 \\
\text { km nord-vest de satul Costi, } \\
\text { pe un platou situat la est de } \\
\text { Valea lui Manolache. }\end{array}$ & - \\
\hline 382 & Neprecizat & $\begin{array}{l}\text { Vânători (com.), } \\
\text { sat Costi }\end{array}$ & $\mathbf{F}$ & $\mathbf{T}$ & Face parte dintr-un grup de 27 de tumuli. & $\begin{array}{l}\text { Grupul se află situat la 4,50 } \\
\text { km nord-vest de satul Costi, } \\
\text { pe un platou situat la est de } \\
\text { Valea lui Manolache. }\end{array}$ & - \\
\hline 383 & Neprecizat & $\begin{array}{l}\text { Vânători (com.), } \\
\text { sat Costi }\end{array}$ & $\mathbf{F}$ & $\mathbf{T}$ & Face parte dintr-un grup de 27 de tumuli. & $\begin{array}{l}\text { Grupul se află situat la 4,50 } \\
\text { km nord-vest de satul Costi, } \\
\text { pe un platou situat la est de } \\
\text { Valea lui Manolache. }\end{array}$ & - \\
\hline 384 & Neprecizat & $\begin{array}{l}\text { Vânători (com.), } \\
\text { sat Costi }\end{array}$ & $\mathbf{F}$ & $\mathbf{T}$ & Face parte dintr-un grup de 27 de tumuli. & $\begin{array}{l}\text { Grupul se află situat la 4,50 } \\
\text { km nord-vest de satul Costi, } \\
\text { pe un platou situat la est de } \\
\text { Valea lui Manolache. }\end{array}$ & - \\
\hline 385 & Neprecizat & $\begin{array}{l}\text { Vânători (com.), } \\
\text { sat Costi }\end{array}$ & $\mathbf{F}$ & $\mathbf{T}$ & Face parte dintr-un grup de 27 de tumuli. & $\begin{array}{l}\text { Grupul se află situat la 4,50 } \\
\text { km nord-vest de satul Costi, } \\
\text { pe un platou situat la est de } \\
\text { Valea lui Manolache. }\end{array}$ & - \\
\hline
\end{tabular}




\begin{tabular}{|c|c|c|c|c|c|c|c|c|c|}
\hline $\begin{array}{l}\text { Nr. } \\
\text { crt. }\end{array}$ & Toponim & Administrativ & B & $\mathbf{C}$ & $\mathbf{F}$ & $\mathbf{T}$ & Descriere & Localizare & Bibliografie \\
\hline
\end{tabular}

\begin{tabular}{|c|c|c|c|c|c|c|c|c|c|}
\hline 386 & Neprecizat & $\begin{array}{l}\text { Vânători (com.), } \\
\text { sat Costi }\end{array}$ & & & $\mathbf{F}$ & $\mathbf{T}$ & Face parte dintr-un grup de 27 de tumuli. & $\begin{array}{l}\text { Grupul se află situat la } 4,50 \\
\text { km nord-vest de satul Costi, } \\
\text { pe un platou situat la est de } \\
\text { Valea lui Manolache. }\end{array}$ & - \\
\hline 387 & $\begin{array}{l}\text { Movila } \\
\text { Turcului }\end{array}$ & $\begin{array}{l}\text { Vânători (com.), } \\
\text { sat Costi }\end{array}$ & B & $\mathbf{C}$ & $\mathbf{F}$ & $\mathbf{T}$ & Dimensiuni: diam. 70 m, h. 5 m. & $\begin{array}{l}\text { La } 3,40 \mathrm{~km} \text { vest de satul } \\
\text { Costi și } 2 \mathrm{~km} \text { est de Valea } \\
\text { lui Manolache. }\end{array}$ & $\begin{array}{l}\text { Brudiu 1991, 51, nr. } \\
\text { 161; Brudiu 2003, } 93- \\
\text { 136, nr. } 161 .\end{array}$ \\
\hline 388 & Neprecizat & $\begin{array}{l}\text { Vânători (com.), } \\
\text { sat Costi }\end{array}$ & B & & $\mathbf{F}$ & $\mathbf{T}$ & Dimensiuni: diam. 40 m, h. 2 m. & $\begin{array}{l}\text { La } 800 \text { m sud-est de Movila } \\
\text { Turcului. }\end{array}$ & $\begin{array}{l}\text { Brudiu 1991, 51, nr. } \\
\text { 162; Brudiu 2003, } 93- \\
\text { 136, nr. } 162 .\end{array}$ \\
\hline 389 & Neprecizat & $\begin{array}{l}\text { Vânători (com.), } \\
\text { sat Costi }\end{array}$ & & & $\mathbf{F}$ & $\mathbf{T}$ & - & La $500 \mathrm{~m}$ est de nr. 388. & - \\
\hline 390 & Neprecizat & $\begin{array}{l}\text { Vânători (com.), } \\
\text { sat Costi }\end{array}$ & & & $\mathbf{F}$ & $\mathbf{T}$ & - & La 300 m est de nr. 389. & - \\
\hline 391 & Neprecizat & $\begin{array}{l}\text { Vânători (com.), } \\
\text { sat Costi }\end{array}$ & & & $\mathbf{F}$ & $\mathbf{T}$ & - & La 250 m est de nr. 390. & - \\
\hline 392 & Neprecizat & $\begin{array}{l}\text { Vânători (com.), } \\
\text { sat Costi }\end{array}$ & & & $\mathbf{F}$ & $\mathbf{T}$ & - & $\begin{array}{l}\text { La 1,50 km sud-vest de } \\
\text { grupul de tumuli (nr. 360- } \\
\text { 386), pe marginea văii Lui } \\
\text { Manolache. }\end{array}$ & - \\
\hline 393 & Neprecizat & $\begin{array}{l}\text { Vânători (com.), } \\
\text { sat Vânători }\end{array}$ & B & & & & Dimensiuni: diam. 25 m, h. 0,90 m. & $\begin{array}{l}\text { Movila se află la } 300 \mathrm{~m} \text { sud } \\
\text { de Movila Turcului (nr. } \\
\text { 387). }\end{array}$ & $\begin{array}{l}\text { Brudiu 2003, 93-136, } \\
\text { nr. } 430 .\end{array}$ \\
\hline 394 & Neprecizat & $\begin{array}{l}\text { Vânători (com.), } \\
\text { sat Costi }\end{array}$ & $\mathbf{B}$ & & & & $\begin{array}{l}\text { Dimensiuni: diam. } 20 \text { m, h. 0,80 m. A dispărut în anul } 1987 \text { odată cu } \\
\text { surparea malului. Se menționează un mormânt de inhumație, dar nu } \\
\text { există alte precizări. }\end{array}$ & $\begin{array}{l}\text { La est de localitate şi la } 60 \\
\text { m sud-est de nr. 398. În } \\
\text { apropierea aeroportului. }\end{array}$ & $\begin{array}{l}\text { Brudiu 2003, 93-136, } \\
\text { nr. } 284 .\end{array}$ \\
\hline 395 & Neprecizat & $\begin{array}{l}\text { Vânători (com.), } \\
\text { sat Vânători }\end{array}$ & B & & $\mathbf{F}$ & & Dimensiuni: diam. 30 m, h. 1 m. & $\begin{array}{l}\text { În partea sudică a } \\
\text { teritoriului comunei } \\
\text { Vânători, la est de DN } 26 \text { și } \\
\text { la } 1 \text { km vest de Balta } \\
\text { Mălina. }\end{array}$ & $\begin{array}{l}\text { Brudiu 1991, 52, nr. } \\
\text { 208; Brudiu 2003, } 93- \\
\text { 136, nr. } 208 .\end{array}$ \\
\hline 396 & Neprecizat & $\begin{array}{l}\text { Vânători (com.), } \\
\text { sat Vânători }\end{array}$ & $\mathbf{B}$ & $\mathbf{C}$ & & & Dimensiuni: diam. 40 m, h. 1,20 m. & $\begin{array}{l}\text { Între şoseaua Galați- } \\
\text { Tulucești și faleza } \\
\text { Brateşului (între Km } 9 \text { şi } \\
\text { 10). }\end{array}$ & $\begin{array}{l}\text { Brudiu 1991, 53, nr. } \\
\text { 227; Brudiu 2003, } 93- \\
\text { 136, nr. } 227 .\end{array}$ \\
\hline 397 & Neprecizat & $\begin{array}{l}\text { Vânători (com.), } \\
\text { sat Vânători }\end{array}$ & $\mathbf{B}$ & $\mathbf{C}$ & & & Dimensiuni: diam. 42 m, h. 1,20 m. & $\begin{array}{l}\text { Între șoseaua Galați- } \\
\text { Tulucești și faleza } \\
\text { Brateşului (între Km } 9 \text { și } \\
\text { 10). }\end{array}$ & $\begin{array}{l}\text { Brudiu 1991, 53, nr. } \\
\text { 228; Brudiu 2003, } 93- \\
\text { 136, nr. } 228 .\end{array}$ \\
\hline 398 & Neprecizat & $\begin{array}{l}\text { Vânători (com.), } \\
\text { sat Vânători }\end{array}$ & B & $\mathbf{C}$ & & & Dimensiuni: diam. 26 m, h. 0,60 m. & $\begin{array}{l}\text { La sud de Râpa lui Tuluc, la } \\
\text { est de șoseaua Galați- } \\
\text { Tulucești, la km } 7+400 .\end{array}$ & $\begin{array}{l}\text { Brudiu 1991, 53, nr. } \\
\text { 230; Brudiu 2003, } 93- \\
\text { 136, nr. } 230 .\end{array}$ \\
\hline
\end{tabular}




\begin{tabular}{|c|c|c|c|c|c|c|c|c|c|}
\hline $\begin{array}{l}\text { Nr. } \\
\text { crt. }\end{array}$ & Toponim & Administrativ & B & C & $\mathbf{F}$ & $\mathbf{T}$ & Descriere & Localizare & Bibliografie \\
\hline
\end{tabular}

\begin{tabular}{|c|c|c|c|c|c|c|c|c|c|}
\hline 399 & Neprecizat & $\begin{array}{l}\text { Vânători (com.), } \\
\text { sat Vânători }\end{array}$ & B & $\mathbf{C}$ & & & Dimensiuni: diam. 30 m, h. 1 m. & $\begin{array}{l}\text { La marginea falezei } \\
\text { Brateșului, la nord de vadul } \\
\text { care duce la poligonul de la } \\
\text { Brateș. }\end{array}$ & $\begin{array}{l}\text { Brudiu 1991, 53, nr. } \\
\text { 231; Brudiu 2003, } 93- \\
\text { 136, nr. } 231 .\end{array}$ \\
\hline 400 & $\begin{array}{l}\text { Movila } \\
\text { Budurului }\end{array}$ & $\begin{array}{l}\text { Vânători (com.), } \\
\text { sat Costi }\end{array}$ & $\mathbf{B}$ & & $\mathbf{F}$ & $\mathbf{T}$ & Dimensiuni: diam. 40 m, h. 2 m. & $\begin{array}{l}\text { La vest de valea Budurului, } \\
\text { la } 1,50 \mathrm{~km} \text { vest de satul } \\
\text { Costi. }\end{array}$ & $\begin{array}{l}\text { Brudiu 1991, 53, nr. } \\
\text { 225; Brudiu 2003, 93- } \\
\text { 136, nr. } 225 .\end{array}$ \\
\hline 401 & Neprecizat & $\begin{array}{l}\text { Vânători (com.), } \\
\text { sat Costi }\end{array}$ & & & $\mathbf{F}$ & $\mathbf{T}$ & - & $\begin{array}{l}\text { La vest de valea Budurului, } \\
\text { la } 1,50 \mathrm{~km} \text { vest de satul } \\
\text { Costi. La } 200 \mathrm{~m} \text { sud de } \mathrm{nr} \text {. } \\
400 .\end{array}$ & 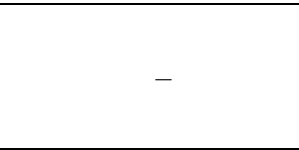 \\
\hline 402 & Neprecizat & $\begin{array}{l}\text { Vânători (com.), } \\
\text { sat Costi }\end{array}$ & & & $\mathbf{F}$ & $\mathbf{T}$ & - & $\begin{array}{l}\text { La vest de valea Budurului, } \\
\text { la } 1,50 \mathrm{~km} \text { vest de satul } \\
\text { Costi. La } 150 \mathrm{~m} \text { sud de } \mathrm{nr} \text {. } \\
401 .\end{array}$ & - \\
\hline 403 & $\begin{array}{l}\text { Movila } \\
\text { Costea }\end{array}$ & $\begin{array}{c}\text { Vânători (com.), } \\
\text { sat Costi }\end{array}$ & & $\mathbf{C}$ & $\mathbf{F}$ & $\mathbf{T}$ & - & $\begin{array}{l}\text { La vest de valea Budurului, } \\
\text { la } 1,50 \mathrm{~km} \text { vest de satul } \\
\text { Costi. La } 850 \mathrm{~m} \text { sud de } \mathrm{nr} \text {. } \\
402 .\end{array}$ & - \\
\hline 404 & Neprecizat & $\begin{array}{c}\text { Vânători (com.), } \\
\text { sat Costi }\end{array}$ & & $\mathbf{C}$ & $\mathbf{F}$ & $\mathbf{T}$ & - & $\begin{array}{l}\text { La vest de valea Budurului, } \\
\text { la } 1,50 \mathrm{~km} \text { vest de satul } \\
\text { Costi. La } 700 \mathrm{~m} \text { sud de } \mathrm{nr} \text {. } \\
\text { 403. }\end{array}$ & - \\
\hline 405 & Neprecizat & Galați (mun.) & & & $\mathbf{F}$ & $\mathbf{T}$ & - & $\begin{array}{l}\text { Pe un platou la } 5 \mathrm{~km} \text { vest de } \\
\text { satul Costi și la } 2 \mathrm{~km} \text { est de } \\
\text { Valea lui Manolache. }\end{array}$ & - \\
\hline 406 & Neprecizat & Galați (mun.) & & & $\mathbf{F}$ & $\mathbf{T}$ & Face parte dintr-un grup de 7 tumuli dispuşi în linie pe dealul Smârdan. & $\begin{array}{l}\text { La } 2 \mathrm{~km} \text { nord-est de } \\
\text { Smârdan, la est de Valea lui } \\
\text { Manolache. }\end{array}$ & - \\
\hline 407 & Neprecizat & Galați (mun.) & & & $\mathbf{F}$ & $\mathbf{T}$ & Face parte dintr-un grup de 7 tumuli dispuşi în linie pe dealul Smârdan. & $\begin{array}{l}\text { La } 1,60 \text { km nord-est de } \\
\text { Smârdan, la est de Valea lui } \\
\text { Manolache. }\end{array}$ & - \\
\hline 408 & Neprecizat & Galați (mun.) & & & $\mathbf{F}$ & $\mathbf{T}$ & Face parte dintr-un grup de 7 tumuli dispuşi în linie pe dealul Smârdan. & $\begin{array}{l}\text { La } 1,40 \mathrm{~km} \text { nord-est de } \\
\text { Smârdan, la est de Valea lui } \\
\text { Manolache. }\end{array}$ & - \\
\hline 409 & Neprecizat & Galați (mun.) & & & $\mathbf{F}$ & $\mathbf{T}$ & Face parte dintr-un grup de 7 tumuli dispuși în linie pe dealul Smârdan. & $\begin{array}{l}\text { La } 1,20 \mathrm{~km} \text { nord-est de } \\
\text { Smârdan, la est de Valea lui } \\
\text { Manolache. }\end{array}$ & - \\
\hline 410 & Neprecizat & Galați (mun.) & & & $\mathbf{F}$ & $\mathbf{T}$ & Face parte dintr-un grup de 7 tumuli dispuşi în linie pe dealul Smârdan. & $\begin{array}{l}\text { La } 1 \mathrm{~km} \text { nord-est de } \\
\text { Smârdan, la est de Valea lui } \\
\text { Manolache. }\end{array}$ & - \\
\hline 411 & Neprecizat & Galați (mun.) & & & $\mathbf{F}$ & $\mathbf{T}$ & Face parte dintr-un grup de 7 tumuli dispuși în linie pe dealul Smârdan. & $\begin{array}{l}\text { La } 700 \text { m nord-est de } \\
\text { Smârdan, la est de Valea lui } \\
\text { Manolache. }\end{array}$ & - \\
\hline
\end{tabular}




\begin{tabular}{|c|c|c|c|c|c|c|c|c|c|}
\hline $\begin{array}{l}\text { Nr. } \\
\text { crt. }\end{array}$ & Toponim & Administrativ & B & C & F & T & Descriere & Localizare & Bibliografie \\
\hline
\end{tabular}

\begin{tabular}{|c|c|c|c|c|c|c|c|c|}
\hline 412 & Neprecizat & Galați (mun.) & $\mathbf{C}$ & $\mathbf{F}$ & $\mathbf{T}$ & Face parte dintr-un grup de 7 tumuli dispuşi în linie pe dealul Smârdan. & $\begin{array}{l}\text { La } 500 \text { m nord-est de } \\
\text { Smârdan, la est de Valea lui } \\
\text { Manolache. }\end{array}$ & - \\
\hline 413 & Neprecizat & Galați (mun.) & & $\mathbf{F}$ & $\mathbf{T}$ & $\begin{array}{l}\text { Face parte dintr-un şir de tumuli situați la est de Smârdan, paralel cu } \\
\text { șirul precedent, pe marginea de vest a Văii Făloaiei. }\end{array}$ & $\begin{array}{l}\text { La 2,50 km nord est de } \\
\text { Smârdan, pe marginea de } \\
\text { est a Văii Făloaiei. }\end{array}$ & - \\
\hline 414 & Neprecizat & Galați (mun.) & & $\mathbf{F}$ & $\mathbf{T}$ & $\begin{array}{l}\text { Face parte dintr-un şir de tumuli situați la est de Smârdan, paralel cu } \\
\text { șirul precedent, pe marginea de vest a Văii Făloaiei. }\end{array}$ & $\begin{array}{l}\text { La } 2,30 \mathrm{~km} \text { nord est de } \\
\text { Smârdan, pe marginea de } \\
\text { est a Văii Făloaiei }\end{array}$ & - \\
\hline 415 & $\begin{array}{l}\text { Movila } \\
\text { Cracul } \\
\text { Făloaiei }\end{array}$ & Galați (mun.) & C & $\mathbf{F}$ & $\mathbf{T}$ & $\begin{array}{l}\text { Face parte dintr-un şir de tumuli situați la est de Smârdan, paralel cu } \\
\text { şirul precedent, pe marginea de vest a Văii Făloaiei. }\end{array}$ & $\begin{array}{l}\text { La } 2,20 \text { km nord est de } \\
\text { Smârdan, pe marginea de } \\
\text { est a Văii Făloaiei. }\end{array}$ & - \\
\hline 416 & Neprecizat & Galați (mun.) & & $\mathbf{F}$ & $\mathbf{T}$ & & $\begin{array}{l}\text { La } 800 \mathrm{~m} \text { sud-vest de nr. } \\
415 \text { și la } 400 \mathrm{~m} \text { est de valea } \\
\text { Coada Mălinei. }\end{array}$ & - \\
\hline 417 & Neprecizat & Galați (mun.) & & $\mathbf{F}$ & $\mathbf{T}$ & $\begin{array}{l}\text { Face parte dintr-un şir de tumuli situați la est de Smârdan, paralel cu } \\
\text { șirul precedent, pe marginea de vest a Văii Făloaiei. }\end{array}$ & $\begin{array}{l}\text { La } 2 \mathrm{~km} \text { est de Smârdan, pe } \\
\text { marginea de est a Văii } \\
\text { Făloaiei. Lângă o fostă } \\
\text { baterie antiaeriană. }\end{array}$ & - \\
\hline 418 & Neprecizat & Galați (mun.) & & $\mathbf{F}$ & & Face parte dintr-un şir de patru tumuli, orientat est-vest. & $\begin{array}{l}\text { La 3,50 km sud-est de satul } \\
\text { Costi. }\end{array}$ & - \\
\hline 419 & Neprecizat & Galați (mun.) & & $\mathbf{F}$ & & Face parte dintr-un şir de patru tumuli, orientat est-vest. & $\begin{array}{l}\text { La } 3,50 \mathrm{~km} \text { sud-est de satul } \\
\text { Costi. }\end{array}$ & - \\
\hline 420 & Neprecizat & Galați (mun.) & & $\mathbf{F}$ & & Face parte dintr-un şir de patru tumuli, orientat est-vest. & $\begin{array}{l}\text { La 3,50 km sud-est de satul } \\
\text { Costi. }\end{array}$ & - \\
\hline 421 & Neprecizat & Galați (mun.) & & $\mathbf{F}$ & & Face parte dintr-un şir de patru tumuli, orientat est-vest. & $\begin{array}{l}\text { La } 3,50 \mathrm{~km} \text { sud-est de satul } \\
\text { Costi. }\end{array}$ & - \\
\hline 422 & Neprecizat & Galați (mun.) & & $\mathbf{F}$ & $\mathbf{T}$ & $\begin{array}{l}\text { Face parte dintr-un șir, sau grup de șiruri, compus din } 32 \text { tumuli (nr. } \\
\text { 421-453) situate pe un platou aflat la vest de Combinatul Siderurgic } \\
\text { Galați și la est de valea Coada Mălinei. Grupul se întinde pe o distanță } \\
\text { de circa 2,50 km pe axa nord-sud. }\end{array}$ & $\begin{array}{l}\text { Prima movilă se află la } 500 \\
\text { m sud-est de drumul DJ } 251 \\
\text { (în punctul de intrare în } \\
\text { satul Smârdan) și continuă } \\
\text { pană la distanța de } 3 \mathrm{~km} \text { de } \\
\text { drum. }\end{array}$ & - \\
\hline 423 & Neprecizat & Galați (mun.) & & $\mathbf{F}$ & $\mathbf{T}$ & $\begin{array}{l}\text { Face parte dintr-un şir, sau grup de șiruri, compus din } 32 \text { tumuli (nr. } \\
421-453 \text { ) situate pe un platou aflat la vest de Combinatul Siderurgic } \\
\text { Galați și la est de valea Coada Mălinei. Grupul se întinde pe o distanță } \\
\text { de circa } 2,50 \mathrm{~km} \text { pe axa nord-sud. }\end{array}$ & $\begin{array}{l}\text { Prima movilă se află la } 500 \\
\text { m sud-est de drumul DJ } 251 \\
\text { (în punctul de intrare în } \\
\text { satul Smârdan) și continuă } \\
\text { pană la distanța de } 3 \mathrm{~km} \text { de } \\
\text { drum. }\end{array}$ & - \\
\hline
\end{tabular}




\begin{tabular}{|c|c|c|c|c|c|c|c|c|c|}
\hline $\begin{array}{l}\text { Nr. } \\
\text { crt. }\end{array}$ & Toponim & Administrativ & B & C & F & T & Descriere & Localizare & Bibliografie \\
\hline
\end{tabular}

\begin{tabular}{|c|c|c|c|c|c|c|c|}
\hline 424 & Neprecizat & Galați (mun.) & $\mathbf{F}$ & $\mathbf{T}$ & $\begin{array}{l}\text { Face parte dintr-un şir, sau grup de şiruri, compus din } 32 \text { tumuli (nr. } \\
421 \text {-453) situate pe un platou aflat la vest de Combinatul Siderurgic } \\
\text { Galați și la est de valea Coada Mălinei. Grupul se întinde pe o distanță } \\
\text { de circa } 2,50 \mathrm{~km} \text { pe axa nord-sud. }\end{array}$ & $\begin{array}{l}\text { Prima movilă se află la } 500 \\
\text { m sud-est de drumul DJ } 251 \\
\text { (în punctul de intrare în } \\
\text { satul Smârdan) și continuă } \\
\text { pană la distanța de } 3 \mathrm{~km} \text { de } \\
\text { drum. }\end{array}$ & - \\
\hline 425 & Neprecizat & Galați (mun.) & $\mathbf{F}$ & $\mathbf{T}$ & $\begin{array}{l}\text { Face parte dintr-un şir, sau grup de șiruri, compus din } 32 \text { tumuli (nr. } \\
421-453 \text { ) situate pe un platou aflat la vest de Combinatul Siderurgic } \\
\text { Galați și la est de valea Coada Mălinei. Grupul se întinde pe o distanță } \\
\text { de circa } 2,50 \mathrm{~km} \text { pe axa nord-sud. }\end{array}$ & $\begin{array}{l}\text { Prima movilă se află la } 500 \\
\text { m sud-est de drumul DJ } 251 \\
\text { (în punctul de intrare în } \\
\text { satul Smârdan) și continuă } \\
\text { pană la distanța de } 3 \mathrm{~km} \text { de } \\
\text { drum. }\end{array}$ & - \\
\hline 426 & Neprecizat & Galați (mun.) & $\mathbf{F}$ & $\mathbf{T}$ & $\begin{array}{l}\text { Face parte dintr-un şir, sau grup de şiruri, compus din } 32 \text { tumuli (nr. } \\
421-453 \text { ) situate pe un platou aflat la vest de Combinatul Siderurgic } \\
\text { Galați și la est de valea Coada Mălinei. Grupul se întinde pe o distanță } \\
\text { de circa } 2,50 \mathrm{~km} \text { pe axa nord-sud. }\end{array}$ & $\begin{array}{l}\text { Prima movilă se află la } 500 \\
\text { m sud-est de drumul DJ } 251 \\
\text { (în punctul de intrare în } \\
\text { satul Smârdan) și continuă } \\
\text { pană la distanța de } 3 \mathrm{~km} \text { de } \\
\text { drum. }\end{array}$ & - \\
\hline 427 & Neprecizat & Galați (mun.) & $\mathbf{F}$ & $\mathbf{T}$ & $\begin{array}{l}\text { Face parte dintr-un şir, sau grup de şiruri, compus din } 32 \text { tumuli (nr. } \\
421-453 \text { ) situate pe un platou aflat la vest de Combinatul Siderurgic } \\
\text { Galați și la est de valea Coada Mălinei. Grupul se întinde pe o distanță } \\
\text { de circa } 2,50 \mathrm{~km} \text { pe axa nord-sud. }\end{array}$ & $\begin{array}{l}\text { Prima movilă se află la } 500 \\
\text { m sud-est de drumul DJ } 251 \\
\text { (în punctul de intrare în } \\
\text { satul Smârdan) și continuă } \\
\text { pană la distanța de } 3 \text { km de } \\
\text { drum. }\end{array}$ & - \\
\hline 428 & Neprecizat & Galați (mun.) & $\mathbf{F}$ & $\mathbf{T}$ & $\begin{array}{l}\text { Face parte dintr-un şir, sau grup de şiruri, compus din } 32 \text { tumuli (nr. } \\
421-453 \text { ) situate pe un platou aflat la vest de Combinatul Siderurgic } \\
\text { Galați și la est de valea Coada Mălinei. Grupul se întinde pe o distanță } \\
\text { de circa } 2,50 \mathrm{~km} \text { pe axa nord-sud. }\end{array}$ & $\begin{array}{l}\text { Prima movilă se află la } 500 \\
\text { m sud-est de drumul DJ } 251 \\
\text { (în punctul de intrare în } \\
\text { satul Smârdan) și continuă } \\
\text { pană la distanța de } 3 \mathrm{~km} \text { de } \\
\text { drum. }\end{array}$ & - \\
\hline 429 & Neprecizat & Galați (mun.) & $\mathbf{F}$ & $\mathbf{T}$ & $\begin{array}{l}\text { Face parte dintr-un şir, sau grup de șiruri, compus din } 32 \text { tumuli (nr. } \\
421-453 \text { ) situate pe un platou aflat la vest de Combinatul Siderurgic } \\
\text { Galați și la est de valea Coada Mălinei. Grupul se întinde pe o distanță } \\
\text { de circa 2,50 km pe axa nord-sud. }\end{array}$ & $\begin{array}{l}\text { Prima movilă se află la } 500 \\
\text { m sud-est de drumul DJ } 251 \\
\text { (în punctul de intrare în } \\
\text { satul Smârdan) și continuă } \\
\text { pană la distanța de } 3 \text { km de } \\
\text { drum. }\end{array}$ & - \\
\hline 430 & Neprecizat & Galați (mun.) & $\mathbf{F}$ & $\mathbf{T}$ & $\begin{array}{l}\text { Face parte dintr-un șir, sau grup de șiruri, compus din } 32 \text { tumuli (nr. } \\
421-453 \text { ) situate pe un platou aflat la vest de Combinatul Siderurgic } \\
\text { Galați și la est de valea Coada Mălinei. Grupul se întinde pe o distanță } \\
\text { de circa 2,50 km pe axa nord-sud. }\end{array}$ & $\begin{array}{l}\text { Prima movilă se află la } 500 \\
\text { m sud-est de drumul DJ } 251 \\
\text { (în punctul de intrare în } \\
\text { satul Smârdan) și continuă } \\
\text { pană la distanța de } 3 \mathrm{~km} \text { de } \\
\text { drum. }\end{array}$ & - \\
\hline
\end{tabular}




\begin{tabular}{|c|c|c|c|c|c|c|c|c|c|}
\hline $\begin{array}{l}\text { Nr. } \\
\text { crt. }\end{array}$ & Toponim & Administrativ & B & C & F & T & Descriere & Localizare & Bibliografie \\
\hline
\end{tabular}

\begin{tabular}{|c|c|c|c|c|c|c|c|c|}
\hline 431 & Neprecizat & Galați (mun.) & & $\mathbf{F}$ & $\mathbf{T}$ & $\begin{array}{l}\text { Face parte dintr-un şir, sau grup de şiruri, compus din } 32 \text { tumuli (nr. } \\
421 \text {-453) situate pe un platou aflat la vest de Combinatul Siderurgic } \\
\text { Galați și la est de valea Coada Mălinei. Grupul se întinde pe o distanță } \\
\text { de circa } 2,50 \mathrm{~km} \text { pe axa nord-sud. }\end{array}$ & $\begin{array}{l}\text { Prima movilă se află la } 500 \\
\text { m sud-est de drumul DJ } 251 \\
\text { (în punctul de intrare în } \\
\text { satul Smârdan) și continuă } \\
\text { pană la distanța de } 3 \mathrm{~km} \text { de } \\
\text { drum. }\end{array}$ & - \\
\hline 432 & Neprecizat & Galați (mun.) & & $\mathbf{F}$ & $\mathbf{T}$ & $\begin{array}{l}\text { Face parte dintr-un şir, sau grup de șiruri, compus din } 32 \text { tumuli (nr. } \\
421-453 \text { ) situate pe un platou aflat la vest de Combinatul Siderurgic } \\
\text { Galați și la est de valea Coada Mălinei. Grupul se întinde pe o distanță } \\
\text { de circa } 2,50 \mathrm{~km} \text { pe axa nord-sud. }\end{array}$ & $\begin{array}{l}\text { Prima movilă se află la } 500 \\
\text { m sud-est de drumul DJ } 251 \\
\text { (în punctul de intrare în } \\
\text { satul Smârdan) și continuă } \\
\text { pană la distanța de } 3 \mathrm{~km} \text { de } \\
\text { drum. }\end{array}$ & - \\
\hline 433 & Neprecizat & Galați (mun.) & & $\mathbf{F}$ & $\mathbf{T}$ & $\begin{array}{l}\text { Face parte dintr-un şir, sau grup de şiruri, compus din } 32 \text { tumuli (nr. } \\
421-453 \text { ) situate pe un platou aflat la vest de Combinatul Siderurgic } \\
\text { Galați și la est de valea Coada Mălinei. Grupul se întinde pe o distanță } \\
\text { de circa } 2,50 \mathrm{~km} \text { pe axa nord-sud. }\end{array}$ & $\begin{array}{l}\text { Prima movilă se află la } 500 \\
\text { m sud-est de drumul DJ } 251 \\
\text { (în punctul de intrare în } \\
\text { satul Smârdan) și continuă } \\
\text { pană la distanța de } 3 \mathrm{~km} \text { de } \\
\text { drum. }\end{array}$ & - \\
\hline 434 & Neprecizat & Galați (mun.) & & $\mathbf{F}$ & $\mathbf{T}$ & $\begin{array}{l}\text { Face parte dintr-un şir, sau grup de şiruri, compus din } 32 \text { tumuli (nr. } \\
421-453 \text { ) situate pe un platou aflat la vest de Combinatul Siderurgic } \\
\text { Galați și la est de valea Coada Mălinei. Grupul se întinde pe o distanță } \\
\text { de circa } 2,50 \mathrm{~km} \text { pe axa nord-sud. }\end{array}$ & $\begin{array}{l}\text { Prima movilă se află la } 500 \\
\text { m sud-est de drumul DJ } 251 \\
\text { (în punctul de intrare în } \\
\text { satul Smârdan) și continuă } \\
\text { pană la distanța de } 3 \text { km de } \\
\text { drum. }\end{array}$ & - \\
\hline 435 & Neprecizat & Galați (mun.) & & $\mathbf{F}$ & $\mathbf{T}$ & $\begin{array}{l}\text { Face parte dintr-un şir, sau grup de şiruri, compus din } 32 \text { tumuli (nr. } \\
421-453 \text { ) situate pe un platou aflat la vest de Combinatul Siderurgic } \\
\text { Galați și la est de valea Coada Mălinei. Grupul se întinde pe o distanță } \\
\text { de circa } 2,50 \mathrm{~km} \text { pe axa nord-sud. }\end{array}$ & $\begin{array}{l}\text { Prima movilă se află la } 500 \\
\text { m sud-est de drumul DJ } 251 \\
\text { (în punctul de intrare în } \\
\text { satul Smârdan) și continuă } \\
\text { pană la distanța de } 3 \mathrm{~km} \text { de } \\
\text { drum. }\end{array}$ & - \\
\hline 436 & Neprecizat & Galați (mun.) & B & $\mathbf{F}$ & $\mathbf{T}$ & $\begin{array}{l}\text { Dimensiuni: diam. } 50 \mathrm{~m}, \mathrm{~h} .3 \mathrm{~m} \text {. Actualmente cuprinsă în limitele } \\
\text { Combinatului Siderurgic Galați. Face parte dintr-un șir, sau grup de } \\
\text { șiruri, compus din } 32 \text { tumuli (nr. } 421 \text {-453) situate pe un platou aflat la } \\
\text { vest de Combinatul Siderurgic Galați și la est de valea Coada Mălinei. } \\
\text { Grupul se întinde pe o distanță de circa } 2,50 \mathrm{~km} \text { pe axa nord-sud. }\end{array}$ & $\begin{array}{l}\text { Prima movilă se află la } 500 \\
\text { m sud-est de drumul DJ } 251 \\
\text { (în punctul de intrare în } \\
\text { satul Smârdan) și continuă } \\
\text { pană la distanța de } 3 \mathrm{~km} \text { de } \\
\text { drum. }\end{array}$ & $\begin{array}{l}\text { Brudiu 1991, 52; } \\
\text { Brudiu 2003, 93-136, } \\
\text { nr. } 207 .\end{array}$ \\
\hline 437 & Neprecizat & Galați (mun.) & & $\mathbf{F}$ & $\mathbf{T}$ & $\begin{array}{l}\text { Face parte dintr-un șir, sau grup de șiruri, compus din } 32 \text { tumuli (nr. } \\
421-453 \text { ) situate pe un platou aflat la vest de Combinatul Siderurgic } \\
\text { Galați și la est de valea Coada Mălinei. Grupul se întinde pe o distanță } \\
\text { de circa 2,50 km pe axa nord-sud. }\end{array}$ & $\begin{array}{l}\text { Prima movilă se află la } 500 \\
\text { m sud-est de drumul DJ } 251 \\
\text { (în punctul de intrare în } \\
\text { satul Smârdan) și continuă } \\
\text { pană la distanța de } 3 \mathrm{~km} \text { de } \\
\text { drum. }\end{array}$ & - \\
\hline
\end{tabular}




\begin{tabular}{|c|c|c|c|c|c|c|c|c|c|}
\hline $\begin{array}{l}\text { Nr. } \\
\text { crt. }\end{array}$ & Toponim & Administrativ & B & C & F & T & Descriere & Localizare & Bibliografie \\
\hline
\end{tabular}

\begin{tabular}{|c|c|c|c|c|c|c|c|c|c|}
\hline 438 & $\begin{array}{c}\text { Movila } \\
\text { Văşmăşeanc } \\
\text { a }\end{array}$ & Galați (mun.) & B & C & $\mathbf{F}$ & $\mathbf{T}$ & $\begin{array}{l}\text { Dimensiuni: diam. } 40 \text { m, h. } 2 \text { m. Actualmente cuprinsă în limitele } \\
\text { Combinatului Siderurgic Galați. Face parte dintr-un șir, sau grup de } \\
\text { șiruri, compus din } 32 \text { tumuli (nr. } 421-453 \text { ) situate pe un platou aflat la } \\
\text { vest de Combinatul Siderurgic Galați și la est de valea Coada Mălinei. } \\
\text { Grupul se întinde pe o distanță de circa } 2,50 \mathrm{~km} \text { pe axa nord-sud. }\end{array}$ & $\begin{array}{l}\text { Prima movilă se află la } 500 \\
\text { m sud-est de drumul DJ } 251 \\
\text { (în punctul de intrare în } \\
\text { satul Smârdan) și continuă } \\
\text { pană la distanța de } 3 \mathrm{~km} \text { de } \\
\text { drum. }\end{array}$ & $\begin{array}{l}\text { Brudiu 1991, 52; } \\
\text { Brudiu 2003, 93-136, } \\
\text { nr. } 206 .\end{array}$ \\
\hline 439 & Neprecizat & Galați (mun.) & & & $\mathbf{F}$ & $\mathbf{T}$ & $\begin{array}{l}\text { Face parte dintr-un şir, sau grup de șiruri, compus din } 32 \text { tumuli (nr. } \\
421-453 \text { ) situate pe un platou aflat la vest de Combinatul Siderurgic } \\
\text { Galați și la est de valea Coada Mălinei. Grupul se întinde pe o distanță } \\
\text { de circa } 2,50 \mathrm{~km} \text { pe axa nord-sud. }\end{array}$ & $\begin{array}{l}\text { Prima movilă se află la } 500 \\
\text { m sud-est de drumul DJ } 251 \\
\text { (în punctul de intrare în } \\
\text { satul Smârdan) și continuă } \\
\text { pană la distanța de } 3 \mathrm{~km} \text { de } \\
\text { drum. }\end{array}$ & - \\
\hline 440 & Neprecizat & Galați (mun.) & & & $\mathbf{F}$ & $\mathbf{T}$ & $\begin{array}{l}\text { Face parte dintr-un şir, sau grup de şiruri, compus din } 32 \text { tumuli (nr. } \\
421-453 \text { ) situate pe un platou aflat la vest de Combinatul Siderurgic } \\
\text { Galați și la est de valea Coada Mălinei. Grupul se întinde pe o distanță } \\
\text { de circa } 2,50 \mathrm{~km} \text { pe axa nord-sud. }\end{array}$ & $\begin{array}{l}\text { Prima movilă se află la } 500 \\
\text { m sud-est de drumul DJ } 251 \\
\text { (în punctul de intrare în } \\
\text { satul Smârdan) și continuă } \\
\text { pană la distanța de } 3 \mathrm{~km} \text { de } \\
\text { drum. }\end{array}$ & - \\
\hline 441 & Neprecizat & Galați (mun.) & & & $\mathbf{F}$ & $\mathbf{T}$ & $\begin{array}{l}\text { Face parte dintr-un şir, sau grup de şiruri, compus din } 32 \text { tumuli (nr. } \\
421-453 \text { ) situate pe un platou aflat la vest de Combinatul Siderurgic } \\
\text { Galați și la est de valea Coada Mălinei. Grupul se întinde pe o distanță } \\
\text { de circa } 2,50 \mathrm{~km} \text { pe axa nord-sud. }\end{array}$ & $\begin{array}{l}\text { Prima movilă se află la } 500 \\
\text { m sud-est de drumul DJ } 251 \\
\text { (în punctul de intrare în } \\
\text { satul Smârdan) și continuă } \\
\text { pană la distanța de } 3 \mathrm{~km} \text { de } \\
\text { drum. }\end{array}$ & - \\
\hline 442 & Neprecizat & Galați (mun.) & & & $\mathbf{F}$ & $\mathbf{T}$ & $\begin{array}{l}\text { Face parte dintr-un şir, sau grup de şiruri, compus din } 32 \text { tumuli (nr. } \\
421-453 \text { ) situate pe un platou aflat la vest de Combinatul Siderurgic } \\
\text { Galați și la est de valea Coada Mălinei. Grupul se întinde pe o distanță } \\
\text { de circa } 2,50 \mathrm{~km} \text { pe axa nord-sud. }\end{array}$ & $\begin{array}{l}\text { Prima movilă se află la } 500 \\
\text { m sud-est de drumul DJ } 251 \\
\text { (în punctul de intrare în } \\
\text { satul Smârdan) și continuă } \\
\text { pană la distanța de } 3 \mathrm{~km} \text { de } \\
\text { drum. }\end{array}$ & - \\
\hline 443 & Neprecizat & Galați (mun.) & & & $\mathbf{F}$ & $\mathbf{T}$ & $\begin{array}{l}\text { Face parte dintr-un şir, sau grup de şiruri, compus din } 32 \text { tumuli (nr. } \\
421-453 \text { ) situate pe un platou aflat la vest de Combinatul Siderurgic } \\
\text { Galați și la est de valea Coada Mălinei. Grupul se întinde pe o distanță } \\
\text { de circa } 2,50 \mathrm{~km} \text { pe axa nord-sud. }\end{array}$ & $\begin{array}{l}\text { Prima movilă se află la } 500 \\
\text { m sud-est de drumul DJ } 251 \\
\text { (în punctul de intrare în } \\
\text { satul Smârdan) și continuă } \\
\text { pană la distanța de } 3 \text { km de } \\
\text { drum. }\end{array}$ & - \\
\hline 444 & Neprecizat & Galați (mun.) & & & $\mathbf{F}$ & $\mathbf{T}$ & $\begin{array}{l}\text { Face parte dintr-un șir, sau grup de șiruri, compus din } 32 \text { tumuli (nr. } \\
421-453 \text { ) situate pe un platou aflat la vest de Combinatul Siderurgic } \\
\text { Galați și la est de valea Coada Mălinei. Grupul se întinde pe o distanță } \\
\text { de circa 2,50 km pe axa nord-sud. }\end{array}$ & $\begin{array}{l}\text { Prima movilă se află la } 500 \\
\text { m sud-est de drumul DJ } 251 \\
\text { (în punctul de intrare în } \\
\text { satul Smârdan) și continuă } \\
\text { pană la distanța de } 3 \mathrm{~km} \text { de } \\
\text { drum. }\end{array}$ & - \\
\hline
\end{tabular}




\begin{tabular}{|c|c|c|c|c|c|c|c|c|c|}
\hline $\begin{array}{l}\text { Nr. } \\
\text { crt. }\end{array}$ & Toponim & Administrativ & B & C & F & T & Descriere & Localizare & Bibliografie \\
\hline
\end{tabular}

\begin{tabular}{|c|c|c|c|c|c|c|c|}
\hline 445 & Neprecizat & Galați (mun.) & $\mathbf{F}$ & $\mathbf{T}$ & $\begin{array}{l}\text { Face parte dintr-un şir, sau grup de şiruri, compus din } 32 \text { tumuli (nr. } \\
421-453 \text { ) situate pe un platou aflat la vest de Combinatul Siderurgic } \\
\text { Galați și la est de valea Coada Mălinei. Grupul se întinde pe o distanță } \\
\text { de circa } 2,50 \mathrm{~km} \text { pe axa nord-sud. }\end{array}$ & $\begin{array}{l}\text { Prima movilă se află la } 500 \\
\text { m sud-est de drumul DJ } 251 \\
\text { (în punctul de intrare în } \\
\text { satul Smârdan) și continuă } \\
\text { pană la distanța de } 3 \mathrm{~km} \text { de } \\
\text { drum. }\end{array}$ & - \\
\hline 446 & Neprecizat & Galați (mun.) & $\mathbf{F}$ & $\mathbf{T}$ & $\begin{array}{l}\text { Face parte dintr-un şir, sau grup de șiruri, compus din } 32 \text { tumuli (nr. } \\
421-453 \text { ) situate pe un platou aflat la vest de Combinatul Siderurgic } \\
\text { Galați și la est de valea Coada Mălinei. Grupul se întinde pe o distanță } \\
\text { de circa } 2,50 \mathrm{~km} \text { pe axa nord-sud. }\end{array}$ & $\begin{array}{l}\text { Prima movilă se află la } 500 \\
\text { m sud-est de drumul DJ } 251 \\
\text { (în punctul de intrare în } \\
\text { satul Smârdan) și continuă } \\
\text { pană la distanța de } 3 \mathrm{~km} \text { de } \\
\text { drum. }\end{array}$ & - \\
\hline 447 & Neprecizat & Galați (mun.) & $\mathbf{F}$ & $\mathbf{T}$ & $\begin{array}{l}\text { Face parte dintr-un şir, sau grup de şiruri, compus din } 32 \text { tumuli (nr. } \\
421-453 \text { ) situate pe un platou aflat la vest de Combinatul Siderurgic } \\
\text { Galați și la est de valea Coada Mălinei. Grupul se întinde pe o distanță } \\
\text { de circa } 2,50 \mathrm{~km} \text { pe axa nord-sud. }\end{array}$ & $\begin{array}{l}\text { Prima movilă se află la } 500 \\
\text { m sud-est de drumul DJ } 251 \\
\text { (în punctul de intrare în } \\
\text { satul Smârdan) și continuă } \\
\text { pană la distanța de } 3 \mathrm{~km} \text { de } \\
\text { drum. }\end{array}$ & - \\
\hline 448 & Neprecizat & Galați (mun.) & $\mathbf{F}$ & $\mathbf{T}$ & $\begin{array}{l}\text { Face parte dintr-un şir, sau grup de şiruri, compus din } 32 \text { tumuli (nr. } \\
421-453 \text { ) situate pe un platou aflat la vest de Combinatul Siderurgic } \\
\text { Galați și la est de valea Coada Mălinei. Grupul se întinde pe o distanță } \\
\text { de circa } 2,50 \mathrm{~km} \text { pe axa nord-sud. }\end{array}$ & $\begin{array}{l}\text { Prima movilă se află la } 500 \\
\text { m sud-est de drumul DJ } 251 \\
\text { (în punctul de intrare în } \\
\text { satul Smârdan) și continuă } \\
\text { pană la distanța de } 3 \text { km de } \\
\text { drum. }\end{array}$ & - \\
\hline 449 & Neprecizat & Galați (mun.) & $\mathbf{F}$ & $\mathbf{T}$ & $\begin{array}{l}\text { Face parte dintr-un şir, sau grup de şiruri, compus din } 32 \text { tumuli (nr. } \\
421-453 \text { ) situate pe un platou aflat la vest de Combinatul Siderurgic } \\
\text { Galați și la est de valea Coada Mălinei. Grupul se întinde pe o distanță } \\
\text { de circa } 2,50 \mathrm{~km} \text { pe axa nord-sud. }\end{array}$ & $\begin{array}{l}\text { Prima movilă se află la } 500 \\
\text { m sud-est de drumul DJ } 251 \\
\text { (în punctul de intrare în } \\
\text { satul Smârdan) și continuă } \\
\text { pană la distanța de } 3 \mathrm{~km} \text { de } \\
\text { drum. }\end{array}$ & - \\
\hline 450 & Neprecizat & Galați (mun.) & $\mathbf{F}$ & $\mathbf{T}$ & $\begin{array}{l}\text { Face parte dintr-un şir, sau grup de șiruri, compus din } 32 \text { tumuli (nr. } \\
421-453 \text { ) situate pe un platou aflat la vest de Combinatul Siderurgic } \\
\text { Galați și la est de valea Coada Mălinei. Grupul se întinde pe o distanță } \\
\text { de circa 2,50 km pe axa nord-sud. }\end{array}$ & $\begin{array}{l}\text { Prima movilă se află la } 500 \\
\text { m sud-est de drumul DJ } 251 \\
\text { (în punctul de intrare în } \\
\text { satul Smârdan) și continuă } \\
\text { pană la distanța de } 3 \text { km de } \\
\text { drum. }\end{array}$ & - \\
\hline 451 & Neprecizat & Galați (mun.) & $\mathbf{F}$ & $\mathbf{T}$ & $\begin{array}{l}\text { Face parte dintr-un șir, sau grup de șiruri, compus din } 32 \text { tumuli (nr. } \\
421-453 \text { ) situate pe un platou aflat la vest de Combinatul Siderurgic } \\
\text { Galați și la est de valea Coada Mălinei. Grupul se întinde pe o distanță } \\
\text { de circa 2,50 km pe axa nord-sud. }\end{array}$ & $\begin{array}{l}\text { Prima movilă se află la } 500 \\
\text { m sud-est de drumul DJ } 251 \\
\text { (în punctul de intrare în } \\
\text { satul Smârdan) și continuă } \\
\text { pană la distanța de } 3 \mathrm{~km} \text { de } \\
\text { drum. }\end{array}$ & - \\
\hline
\end{tabular}




\begin{tabular}{|c|c|c|c|c|c|c|c|c|c|}
\hline $\begin{array}{l}\text { Nr. } \\
\text { crt. }\end{array}$ & Toponim & Administrativ & B & $\mathbf{C}$ & $\mathbf{F}$ & $\mathbf{T}$ & Descriere & Localizare & Bibliografie \\
\hline
\end{tabular}

\begin{tabular}{|c|c|c|c|c|c|c|c|c|c|}
\hline 452 & Neprecizat & Galați (mun.) & & & $\mathbf{F}$ & $\mathbf{T}$ & $\begin{array}{l}\text { Face parte dintr-un șir, sau grup de șiruri, compus din } 32 \text { tumuli (nr. } \\
421-453 \text { ) situate pe un platou aflat la vest de Combinatul Siderurgic } \\
\text { Galați și la est de valea Coada Mălinei. Grupul se întinde pe o distanță } \\
\text { de circa } 2,50 \mathrm{~km} \text { pe axa nord-sud. }\end{array}$ & $\begin{array}{l}\text { Prima movilă se află la } 500 \\
\text { m sud-est de drumul DJ } 251 \\
\text { (în punctul de intrare în } \\
\text { satul Smârdan) și continuă } \\
\text { pană la distanța de } 3 \mathrm{~km} \text { de } \\
\text { drum. }\end{array}$ & - \\
\hline 453 & Neprecizat & Galați (mun.) & & $\mathbf{C}$ & $\mathbf{F}$ & $\mathbf{T}$ & $\begin{array}{l}\text { Face parte dintr-un șir, sau grup de șiruri, compus din } 32 \text { tumuli (nr. } \\
421-453 \text { ) situate pe un platou aflat la vest de Combinatul Siderurgic } \\
\text { Galați și la est de valea Coada Mălinei. Grupul se întinde pe o distanță } \\
\text { de circa } 2,50 \mathrm{~km} \text { pe axa nord-sud. }\end{array}$ & $\begin{array}{l}\text { Prima movilă se află la } 500 \\
\text { m sud-est de drumul DJ } 251 \\
\text { (în punctul de intrare în } \\
\text { satul Smârdan) și continuă } \\
\text { pană la distanța de } 3 \mathrm{~km} \text { de } \\
\text { drum. }\end{array}$ & - \\
\hline 454 & Neprecizat & Galați (mun.) & $\mathbf{B}$ & $\mathbf{C}$ & & & Dimensiuni: diam. 60 m, h. 3 m. & $\begin{array}{l}\text { În zona nordică a platformei } \\
\text { Combinatului siderurgic } \\
\text { Galați, în incinta acestuia. }\end{array}$ & $\begin{array}{l}\text { Brudiu 1991, 52; } \\
\text { Brudiu 2003, 93-136, } \\
\text { nr. } 204 .\end{array}$ \\
\hline 455 & $\begin{array}{c}\text { Movila } \\
\text { Capul } \\
\text { Făloaiei }\end{array}$ & Galați (mun.) & B & $\mathbf{C}$ & & & Dimensiuni: diam. 40 m, h. 2 m. & $\begin{array}{l}\text { În zona nordică a platformei } \\
\text { Combinatului siderurgic } \\
\text { Galați, în incinta acestuia. }\end{array}$ & $\begin{array}{l}\text { Brudiu 1991, 52; } \\
\text { Brudiu 2003, 93-136, } \\
\text { nr. } 205 .\end{array}$ \\
\hline 456 & $\begin{array}{l}\text { Tumulul de } \\
\text { la Termogal } \\
\text { S.A. }\end{array}$ & Galați (mun.) & $\mathbf{B}$ & & & & $\begin{array}{l}\text { Săpăturile au fost efectuate în anul } 1977 \text { de către M. Brudiu și Limbidis } \\
\text { în satul Filești, din teritoriul mun. Galați (actualmente cartier Filești din } \\
\text { Galați). Tumulul este aplatizat cu dimensiunile de } 1,20 \text { m înălțime și } 27 \\
\text { m diametrul maxim. Au fost cercetate două morminte, unul principal și } \\
\text { unul secundar, de inhumație dispuse în centrul tumulii. Nici unul dintre } \\
\text { morminte nu are inventar, dar în urma analizelor antropologice s-a } \\
\text { dovedit că acesta aparține unei populații turanice. Al doilea mormânt are } \\
\text { un inventar compus din un vas ceramic lucrat cu mâna (sarmatic), un } \\
\text { fragment de amforă romană, mărgele din sticlă de diferite culori, } 28 \text { de } \\
\text { aplice din aur, doi cercei din aur și două piese din aur care au făcut parte } \\
\text { dintr-o diademă. Mormântul a aparținut unei femei, aceasta a fost } \\
\text { neînhumată, fapt care împreună cu inventarul implică o apartenență la } \\
\text { cultura sarmatică. }\end{array}$ & $\begin{array}{l}\text { Se află la interfluviul dintre } \\
\text { valea Făloaia și valea } \\
\text { Cătușa. }\end{array}$ & $\begin{array}{l}\text { Brudiu, Limbidis 1979 } \\
\text { (Dacia NS), 324-331; } \\
\text { Brudiu 1991, 52; } \\
\text { Brudiu 2003, 93-136, } \\
\text { nr. 209; Nicolăescu-- } \\
\text { Plopșor 1979, 333-338. }\end{array}$ \\
\hline 457 & $\begin{array}{l}\text { Movila } \\
\text { Tăiată }\end{array}$ & Galați (mun.) & $\mathbf{B}$ & & & & $\begin{array}{l}\text { Movila are o înălțime de aprox. } 8 \text { m, iar laturile de nord și de sud sunt } \\
\text { tăiate. Versanții de vest și de est au o înclinație de cca } 70 \text { grade, astfel } \\
\text { diametrul la bază este de cca } 60 \mathrm{~m} \text {. Se află în perimetrul intravilan pe } \\
\text { proprietatea lui Ștefan Puiu. posibil să acopere un cavou de epocă } \\
\text { romană. }\end{array}$ & $\begin{array}{l}\text { La NV de Filatură, pe } \\
\text { proprietatea lui Ștefan Puiu. } \\
\text { Are bornă. }\end{array}$ & $\begin{array}{l}\text { Brudiu 2003, 93-136, } \\
\text { nr. } 385 .\end{array}$ \\
\hline 458 & Neprecizat & $\begin{array}{l}\text { Galați (mun.), } \\
\quad \text { Sidex }\end{array}$ & B & & & & $\begin{array}{l}\text { Dimensiuni: diam. } 30 \text { m, h. 1,50 m. Săpături făcute în anul } 1971 \text { de } \\
\text { Limbidis și N. Ghiser. }\end{array}$ & $\begin{array}{l}\text { La intrarea în combinatul } \\
\text { siderurgic, } 400 \mathrm{~m} \text { sud de } \\
\text { viaduct. }\end{array}$ & $\begin{array}{l}\text { Brudiu, Limbidis } 1979 \\
\text { (Dacia NS), 323-333; } \\
\text { Brudiu 1991, 52; } \\
\text { Brudiu 2003, 93-136, } \\
\text { nr. 210. }\end{array}$ \\
\hline 459 & Neprecizat & $\begin{array}{l}\text { Galați (mun.), } \\
\text { Sidex }\end{array}$ & & $\mathbf{C}$ & & & - & $\begin{array}{l}\text { La intrare în C. S. Galați, la } \\
300 \mathrm{~m} \text { sud de viaduct. }\end{array}$ & - \\
\hline
\end{tabular}




\begin{tabular}{|c|c|c|c|c|c|c|c|c|c|}
\hline $\begin{array}{l}\text { Nr. } \\
\text { crt. }\end{array}$ & Toponim & Administrativ & B & $\mathbf{C}$ & $\mathbf{F}$ & $\mathbf{T}$ & Descriere & Localizare & Bibliografie \\
\hline
\end{tabular}

\begin{tabular}{|c|c|c|c|c|c|c|c|}
\hline 460 & Neprecizat & $\begin{array}{l}\text { Galați (mun.), } \\
\text { Sidex }\end{array}$ & & C & - & $\begin{array}{l}\text { La intrare în C. S. Galați, la } \\
300 \text { m nord de viaduct. }\end{array}$ & - \\
\hline 461 & Neprecizat & $\begin{array}{l}\text { Galați (mun.), } \\
\text { Sidex }\end{array}$ & & $\mathbf{C}$ & - & $\begin{array}{l}\text { La intrare în C. S. Galați, la } \\
300 \text { m nord de viaduct. }\end{array}$ & - \\
\hline 462 & Neprecizat & $\begin{array}{l}\text { Galați (mun.), } \\
\text { Sidex }\end{array}$ & & C & - & $\begin{array}{l}\text { La } 3 \text { km est de Balta Mălina } \\
\text { și al } 2 \text { km vest de Balta } \\
\text { Cătușa. }\end{array}$ & - \\
\hline 463 & Neprecizat & $\begin{array}{l}\text { Galați (mun.), } \\
\text { Sidex }\end{array}$ & & C & - & $\begin{array}{l}\text { La } 2 \text { km est de Balta Mălina } \\
\text { și al } 3 \text { km vest de Balta } \\
\text { Cătușa. }\end{array}$ & - \\
\hline 464 & $\begin{array}{l}\text { Tumulul de } \\
\text { la Furnalul } \\
\text { Nr.6 }\end{array}$ & $\begin{array}{l}\text { Galați (mun.), } \\
\text { Sidex }\end{array}$ & B & & $\begin{array}{l}\text { În timpul unor săpături de salvare pe proprietatea combinatului } \\
\text { siderurgic Galați s-a cercetat un tumul cu o înălțime păstrată de cca } 3 \text { m } \\
\text { și un diametru de } 40 \text { m. Acesta conținea două morminte de inhumație, } \\
\text { aflate în poziție centrală, nivelul de amenajare al gropii aflându-se la - } \\
2,50 \text { m adâncime. Inventarul mormintelor este bogat și specific } \\
\text { populațiilor sarmatice: mai multe mărgele de sticlă de diferite culori, } \\
\text { pandantive din os, fragment dintr-un bol din sticlă romană de tip } \\
\text { millefiori, fragmente de amfore romane etc. Groapa mormântului } \\
\text { prezenta urme de intervenție antropică ulterioară ultimei înmormântări. }\end{array}$ & $\begin{array}{l}\text { Pe dealul Şoldana, în } \\
\text { incinta platformei } \\
\text { combinatului, pe locul unde } \\
\text { s-a construit ulterior } \\
\text { Furnalul nr. } 6 \text {. }\end{array}$ & $\begin{array}{l}\text { Brudiu 1991, 52; } \\
\text { Brudiu 2003, 93-136, } \\
\text { nr. } 211 .\end{array}$ \\
\hline 465 & $\begin{array}{l}\text { Movila } \\
\text { Tereghina }\end{array}$ & Galați (mun.) & B & $\mathbf{C}$ & $\begin{array}{l}\text { Descoperirea a fost făcută în decembrie 1982, cu prilejul unor lucrări } \\
\text { pentru Combinatul Siderurgic Galați, iar tumulul a fost distrus aproape } \\
\text { în întregime. Din inventarul recuperat se pot menționa: două căni } \\
\text { ceramice întregi şi un vas antropomorf (de tip Kopfgefäss) din bronz } \\
\text { întruchipând un bărbat cu barbă și plete. }\end{array}$ & $\begin{array}{l}\text { Situat la piciorul dealului } \\
\text { Tirighina-Barboși, punct } \\
\text { situat aproximativ la } 500 \mathrm{~m} \\
\text { bord de zidurile de incintă } \\
\text { ale castrului roman, în } \\
\text { dreptul ,punctului de } \\
\text { control al circulației” pe } \\
\text { șoseaua Galați-Brăila- } \\
\text { Tecuci. }\end{array}$ & $\begin{array}{l}\text { Dragomir 1996, 525- } \\
528 .\end{array}$ \\
\hline 466 & Neprecizat & Galați (mun.) & B & & $\begin{array}{l}\text { Tumul în care la } 1867 \text { s-a descoperit un cavou roman de către „Dobre”, } \\
\text { proprietarul terenului. Cavoul conținea un sarcofag din piatră }(\mathrm{L}=2,40 \\
\mathrm{m} ; 1=0,93 \mathrm{~m} ; \mathrm{h}=0,80 \mathrm{~m}) \text {, cu capacul și o laterală sparte încă din } \\
\text { antichitate. Capacul sarcofagului este sculptat simetric pe acrotere, pe o } \\
\text { parte cu un taur încadrat de trei rozete, iar pe cealaltă cu o reprezentare a } \\
\text { zeului Mithras călare încadrat de aceleași rozete. }\end{array}$ & $\begin{array}{l}\text { Situat la capătul nordic al } \\
\text { str. Lozoveni. }\end{array}$ & $\begin{array}{l}\text { Păltânea } 1972,383- \\
\text { 386; Brudiu 2003, } 93- \\
\text { 136, nr. 380; Croitoru } \\
\text { 2013, } 98 .\end{array}$ \\
\hline 467 & $\begin{array}{l}\text { Movila } \\
\text { Comoara }\end{array}$ & Galați (mun.) & $\mathbf{B}$ & & Este menționată la 1050 m N-NV de Cimitirul Eternitatea, în anul 1883. & $\begin{array}{l}\text { Micro } 40 \text { la } 1050 \mathrm{~m} \text { N-NV } \\
\text { de Cimitirul Eternitatea. }\end{array}$ & $\begin{array}{l}\text { Arhiva Naționala fil. } \\
\text { Galați, dos. 481; Brudiu } \\
\text { 2003, 93-136, nr. } 364 .\end{array}$ \\
\hline 468 & Neprecizat & Galați (mun.) & $\mathbf{B}$ & & $\begin{array}{l}\text { Este menționată la } 25 \mathrm{~m} \text { de clopotnița Cimitirul Eternitatea, dincolo de } \\
\text { zidul cimitirului. Nu se menționează stadiul de prezervare, dimensiunile } \\
\text { sau componența inventarului descoperirilor (în cazul în care a fost } \\
\text { cercetată). }\end{array}$ & $\begin{array}{l}\text { La } 25 \text { m de clopotnița } \\
\text { Cimitirului Eternitatea, } \\
\text { dincolo de zid. }\end{array}$ & $\begin{array}{l}\text { Brudiu 2003, 93-136, } \\
\text { nr. } 373 .\end{array}$ \\
\hline
\end{tabular}




\begin{tabular}{|c|c|c|c|c|c|c|c|c|c|}
\hline $\begin{array}{l}\text { Nr. } \\
\text { crt. }\end{array}$ & Toponim & Administrativ & B & C & F & T & Descriere & Localizare & Bibliografie \\
\hline
\end{tabular}

\begin{tabular}{|c|c|c|c|c|c|c|c|c|c|}
\hline 469 & Neprecizat & Galați (mun.) & B & & & & $\begin{array}{l}\text { Movila este menționată la } 1 \mathrm{~km} \text { vest de Cimitirul Eternitatea, în anul } \\
\text { 1884. Nu se menționează dimensiuni sau inventarul descoperirilor. }\end{array}$ & $\begin{array}{l}\text { La1 } \mathrm{km} \text { vest de Cimitirul } \\
\text { Eternitatea, în anul } 1884 \text {. }\end{array}$ & $\begin{array}{l}\text { Arhiva Naționala fil. } \\
\text { Galați, dos. 481; Brudiu } \\
\text { 2003, } 93-136 \text {, nr. } 365 .\end{array}$ \\
\hline 470 & Neprecizat & Galați (mun.) & B & & & & $\begin{array}{l}\text { Movilă distrusă în anul } 1986 \text { cu prilejul construcției unei hale } \\
\text { industriale. S-a observat prezența de oseminte umane. }\end{array}$ & $\begin{array}{l}\text { Intersecția Blv. G. Coşbuc } \\
\text { cu str. Sf. Impărați, tangentă } \\
\text { cu str. Tumulii. }\end{array}$ & $\begin{array}{l}\text { Brudiu 2003, 93-136, } \\
\text { nr. } 371 .\end{array}$ \\
\hline 471 & Neprecizat & Galați (mun.) & B & & & & $\begin{array}{l}\text { Movila făcea parte dintr-un grup de } 15 \text { tumuli menționați într-o } \\
\text { hotărnicie din anul } 1819 \text {, astăzi dispăruți. Aceştia erau poziționați în linie } \\
\text { dreaptă, pe direcția N-S, începând din zona Trustului de Construcții } \\
\text { (fostul Regiment } 11 \text { Siret), pe traseul Blv. G. Coșbuc, până la Bariera } \\
\text { Traian. }\end{array}$ & $\begin{array}{l}\text { Intersecția str. Tecuci cu } \\
\text { Blv. G. Coşbuc. }\end{array}$ & $\begin{array}{l}\text { Brudiu 2003, 93-136, } \\
\text { nr. } 370 .\end{array}$ \\
\hline 472 & Neprecizat & Galați (mun.) & B & & & & $\begin{array}{l}\text { Tumulul a fost distrus în 1963-1964, fiind săpat cu escavatorul în cadrul } \\
\text { construcției unui centru comercial, astăzi Palatul Justiției. Au fost } \\
\text { consemnate resturi de oseminte umane. }\end{array}$ & $\begin{array}{l}\text { Intersecția str. Brăilei cu } \\
\text { Blv. G. Coșbuc. }\end{array}$ & $\begin{array}{l}\text { Brudiu 2003, 93-136, } \\
\text { nr. } 369 .\end{array}$ \\
\hline 473 & $\begin{array}{l}\text { Movila } \\
\text { Țiglina }\end{array}$ & $\begin{array}{l}\text { Galați (mun.) } \\
\text { Barboși }\end{array}$ & B & $\mathbf{C}$ & & $\mathbf{T}$ & $\begin{array}{l}\text { Movila este atestată pentru prima oară într-o hotarnică din } 1819 \text { cu } \\
\text { denumirea de „Movila Țiglina” (Brudiu 2003, 117). Partea superioară } \\
\text { fost distrusă în 1964, dar din relatări dimensiunile erau impresionante, } \\
\text { peste } 60 \text { m diametru și o înălțime de } 4 \text { m. În 1974, cu prilejul } \\
\text { construcției unui bloc de locuințe s-au efectuat săpături de salvare, } \\
\text { conduse de M. Brudiu. Astfel a fost descoperit un cavou din piatră și } \\
\text { cărămidă, de formă trapezoidală în plan cu dromos. Cavoul avea două } \\
\text { încăperi, nedespărțite prin zidărie, tencuite cu mortar şi pictate cu nuanțe } \\
\text { de roșu. tavanul era sub formă de boltă, dar acesta a fost în mare parte } \\
\text { distrus de cupa escavatorului (Brudiu 1976, 85-96). Cărămizile și țiglele } \\
\text { folosite la construcție erau în bună măsură ștampilate (55 de cărămizi și } \\
\text { țigle cu ștampila Classis Flavia Moesica, tipul CL FL MY). Defunctul a } \\
\text { fost depus într-o nișă din peretele de vest al camerei mari, dar oase din } \\
\text { scheletul acestuia se găsesc răsfirate în întreaga încăpere. M. Brudiu } \\
\text { susține faptul că acest mormânt a fost jefuit, acest fapt cauzând } \\
\text { distrugerea interiorului, iar nu lucrările de amenajare moderne din zonă. } \\
\text { Din inventarul mormântului s-au mai păstrat: cinci garnituri din foiț̆ă de } \\
\text { argint, trei bucăți din fier aurite, o strachină lucrată la roată, fragmente de } \\
\text { amfore romane, o oală cu decor canelat orizontal și angobă roșie, } \\
\text { fragmente de cățuie și mai multe plăsele din corn de cerbidee. }\end{array}$ & $\begin{array}{l}\text { Movila se află la nord de } \\
\text { Turnul de televiziune, pe } \\
\text { Bulevardul Oțelarilor, lângă } \\
\text { blocul de locuințe D-15. }\end{array}$ & $\begin{array}{l}\text { Brudiu 1976, 85-96; } \\
\text { Brudiu 1991, 53; } \\
\text { Brudiu 2003, 93-136, } \\
\text { nr. 257. Dragomir 1996, } \\
\text { 391. }\end{array}$ \\
\hline 474 & Neprecizat & $\begin{array}{l}\text { Galați (mun.) } \\
\text { Barboși }\end{array}$ & B & $\mathbf{C}$ & $\mathbf{F}$ & & $\begin{array}{l}\text { Necropolă ce conținea pe lângă morminte plane și } 19 \text { tumuli. A fost } \\
\text { cercetată în } 1980 \text { de către M. Brudiu. }\end{array}$ & La nord de castellum. & $\begin{array}{l}\text { Brudiu 1991, 53; } \\
\text { Brudiu 2003, 93-136, } \\
\text { nr. 237-256. }\end{array}$ \\
\hline 475 & Neprecizat & $\begin{array}{l}\text { Galați (mun.), } \\
\text { cartierul Dunărea }\end{array}$ & B & & & & $\begin{array}{l}\text { A fost cercetată de M. Brudiu în anii 1981-1982 şi face parte din } \\
\text { necropola mixtă a castellum-ului roman din apropiere. Dimensiuni: } \\
\text { diam. } 33 \text { m, h. o înălțime păstrată de } 1 \mathrm{~m} \text {. }\end{array}$ & $\begin{array}{l}\text { La SV de cartierul Dunărea, } \\
\text { făcând parte din necropola } \\
\text { din apropierea castellum- } \\
\text { ului. }\end{array}$ & $\begin{array}{l}\text { Brudiu 1991, 54, nr. } \\
\text { 259; Brudiu 2003, 93- } \\
\text { 136, nr. 259. Dragomir } \\
1996,391 .\end{array}$ \\
\hline
\end{tabular}




\begin{tabular}{|c|c|c|c|c|c|c|c|c|c|}
\hline $\begin{array}{l}\text { Nr. } \\
\text { crt. }\end{array}$ & Toponim & Administrativ & B & $\mathbf{C}$ & $\mathbf{F}$ & $\mathbf{T}$ & Descriere & Localizare & Bibliografie \\
\hline
\end{tabular}

\begin{tabular}{|c|c|c|c|c|c|c|c|c|}
\hline 476 & Neprecizat & $\begin{array}{l}\text { Galați (mun.), } \\
\text { cartierul Dunărea }\end{array}$ & $\mathbf{B}$ & & & $\begin{array}{l}\text { A fost cercetată în } 1976 \text { de M. Brudiu și I. Limbidis și avea o înălțime de } \\
\text { cca } 1,20 \text { m. Au fost cercetate } 10 \text { morminte aparținând culturii Monteoru } \\
\text { II (bronz mijlociu) precum și unul din secolul XIX. Inventarul } \\
\text { mormintelor de epoca bronzului, din care } 5 \text { nu au avut inventar, este } \\
\text { foarte auster, datarea s-a făcut pe baza unei căni din ceramică și a unei } \\
\text { dăltițe din bronz din mormântul M11. Autorii cercetărilor menționează } \\
\text { faptul că movila a avut un șanț care o înconjura, cu dimensiunile de } \\
0,80-1 \text { m lățime și } 0,60 \text { m adâncime. }\end{array}$ & $\begin{array}{l}\text { Pe terasa superioară a } \\
\text { Siretului în actualul Cartier } \\
\text { Dunărea (între blocurile } \\
\text { A11 și A12). }\end{array}$ & $\begin{array}{l}\text { Brudiu 1984, 235-248; } \\
\text { Brudiu 1991, 54; } \\
\text { Brudiu 2003, 59-62, } \\
\text { 93-136, nr. 258. } \\
\text { Dragomir 1996, } 391 .\end{array}$ \\
\hline 477 & Neprecizat & $\begin{array}{l}\text { Galați (mun.), } \\
\text { cartierul Țiglina }\end{array}$ & $\mathbf{B}$ & & & Dimensiuni: diam. 34 m, h. 1 m. & $\begin{array}{l}\text { La vest de cartierul Țiglina } \\
\text { III, într-o vie. }\end{array}$ & $\begin{array}{l}\text { Brudiu 1991, 54, nr. } \\
\text { 261; Brudiu 2003, } 93- \\
\text { 136, nr. } 261 .\end{array}$ \\
\hline 478 & Neprecizat & $\begin{array}{l}\text { Galați (mun.) } \\
\quad \text { Sidex }\end{array}$ & $\mathbf{B}$ & $\mathbf{C}$ & & Dimensiuni: diam. 32 m, h. 1 m. & $\begin{array}{l}\text { La sud de B-dul Viaductului } \\
\text { de la Combinatul Siderurgic } \\
\text { Galați, spre Valea Viilor. }\end{array}$ & $\begin{array}{l}\text { Brudiu 1991, 54; } \\
\text { Brudiu 2003, 93-136, } \\
\text { nr. } 262 .\end{array}$ \\
\hline 479 & Neprecizat & $\begin{array}{l}\text { Galați (mun.), } \\
\text { Sidex }\end{array}$ & & $\mathbf{C}$ & & & $\begin{array}{l}\text { La 1,40 km nord, în linie } \\
\text { dreaptă, față de nr. } 478 .\end{array}$ & (1) \\
\hline 480 & Neprecizat & $\begin{array}{l}\text { Galați (mun.), } \\
\text { cartierul Dunărea }\end{array}$ & B & & & $\begin{array}{l}\text { Tumulul a fost distrus în 1971, cu ocazia construirii terasamentului } \\
\text { pentru banda transportoare dintre Portul Mineralier și Combinatul } \\
\text { Siderurgic Galați. Tumulul avea dimensiunile de } 6 \text { m diametru, } 4 \mathrm{~m} \\
\text { înălțime, iar după toate aparențele a avut și un cavou. Tumulul mai este } \\
\text { semnalat și într-o hotărnicie din 1884, aceasta fiind pe terenurile } \\
\text { Societății Helvețiene. }\end{array}$ & $\begin{array}{l}\text { Tumulul se află la } 150 \text { m est } \\
\text { de castellum-ul de pământ } \\
\text { atestat în această zonă și la } \\
700 \text { m de şoseaua Galați- } \\
\text { Brăila. }\end{array}$ & $\begin{array}{l}\text { Arhiva Naționala fil. } \\
\text { Galați, dos. } 481 \text {; Brudiu } \\
\text { 2003, } 93-136 \text {, nr. } 363 .\end{array}$ \\
\hline 481 & Neprecizat & $\begin{array}{l}\text { Galați (mun.), } \\
\text { Blv. G. Coșbuc }\end{array}$ & $\mathbf{B}$ & & & $\begin{array}{l}\text { Un grup de } 15 \text { tumuli menționați într-o hotărnicie din anul 1819, astăzi } \\
\text { dispăruți. Aceștia erau poziționați în linie dreaptă, pe direcția N-S, } \\
\text { începând din zona Trustului de Construcții (fostul Regiment } 11 \text { Siret), pe } \\
\text { traseul Blv. G. Coșbuc, până la Bariera Traian. (nr. 530-543 și 481) }\end{array}$ & $\begin{array}{l}\text { Poziționați în linie dreaptă } \\
\text { începând de la actualul } \\
\text { Trust de Construcții, pe } \\
\text { traseul Bd. G. Coșbuc, până } \\
\text { la Bariera Traian. }\end{array}$ & $\begin{array}{l}\text { Brudiu 2003, 93-136, } \\
\text { nr. 368-385. }\end{array}$ \\
\hline 482 & Neprecizat & $\begin{array}{l}\text { Galați (mun.) } \\
\text { Barboși }\end{array}$ & $\mathbf{B}$ & $\mathbf{C}$ & $\mathbf{F}$ & $\begin{array}{l}\text { Necropolă ce conținea pe lângă morminte plane și } 19 \text { tumuli. A fost } \\
\text { cercetată în } 1980 \text { de către M. Brudiu. }\end{array}$ & La nord de castellum. & $\begin{array}{l}\text { Brudiu 1991, 53; } \\
\text { Brudiu 2003, 93-136, } \\
\text { nr. 237-256. }\end{array}$ \\
\hline 483 & Neprecizat & $\begin{array}{l}\text { Galați (mun.) } \\
\text { Barboși }\end{array}$ & $\mathbf{B}$ & $\mathbf{C}$ & $\mathbf{F}$ & $\begin{array}{l}\text { Necropolă ce conținea pe lângă morminte plane şi } 19 \text { tumuli. A fost } \\
\text { cercetată în } 1980 \text { de către M. Brudiu. }\end{array}$ & La nord de castellum. & $\begin{array}{l}\text { Brudiu 1991, 53; } \\
\text { Brudiu 2003, 93-136, } \\
\text { nr. } 237-256 .\end{array}$ \\
\hline 484 & Neprecizat & $\begin{array}{l}\text { Galați (mun.) } \\
\text { Barboși }\end{array}$ & $\mathbf{B}$ & $\mathbf{C}$ & $\mathbf{F}$ & $\begin{array}{l}\text { Necropolă ce conținea pe lângă morminte plane și } 19 \text { tumuli. A fost } \\
\text { cercetată în } 1980 \text { de către M. Brudiu. }\end{array}$ & La nord de castellum. & $\begin{array}{l}\text { Brudiu 1991, 53; } \\
\text { Brudiu 2003, 93-136, } \\
\text { nr. 237-256. }\end{array}$ \\
\hline 485 & Neprecizat & $\begin{array}{l}\text { Galați (mun.) } \\
\text { Barboși }\end{array}$ & $\mathbf{B}$ & $\mathbf{C}$ & $\mathbf{F}$ & $\begin{array}{l}\text { Necropolă ce conținea pe lângă morminte plane și } 19 \text { tumuli. A fost } \\
\text { cercetată în } 1980 \text { de către M. Brudiu. }\end{array}$ & La nord de castellum. & $\begin{array}{l}\text { Brudiu 1991, 53; } \\
\text { Brudiu 2003, 93-136, } \\
\text { nr. 237-256. }\end{array}$ \\
\hline 486 & Neprecizat & $\begin{array}{l}\text { Smârdan (com.) } \\
\text { sat Smârdan }\end{array}$ & $\mathbf{B}$ & & & Dimensiuni: diam. 30 m, h. 1 m. & $\begin{array}{l}\text { La est de cursul superior al } \\
\text { văii Mălina. }\end{array}$ & $\begin{array}{l}\text { Brudiu 1991, 51; } \\
\text { Brudiu 2003, 93-136, } \\
\text { nr. } 158 .\end{array}$ \\
\hline
\end{tabular}




\begin{tabular}{|c|c|c|c|c|c|c|c|c|c|}
\hline $\begin{array}{l}\text { Nr. } \\
\text { crt. }\end{array}$ & Toponim & Administrativ & B & $\mathbf{C}$ & $\mathbf{F}$ & $\mathbf{T}$ & Descriere & Localizare & Bibliografie \\
\hline
\end{tabular}

\begin{tabular}{|c|c|c|c|c|c|c|c|c|c|}
\hline 487 & Neprecizat & $\begin{array}{l}\text { Smârdan (com.), } \\
\text { sat Smârdan }\end{array}$ & $\mathbf{B}$ & & & & Dimensiuni: diam. 30 m, h. 1 m. & La 1 km est de nr. 486. & $\begin{array}{l}\text { Brudiu 1991, 51; } \\
\text { Brudiu 2003, 93-136, } \\
\text { nr. } 159 .\end{array}$ \\
\hline 488 & Neprecizat & $\begin{array}{l}\text { Galați (mun.) } \\
\text { Barboși }\end{array}$ & B & $\mathbf{C}$ & $\mathbf{F}$ & & $\begin{array}{l}\text { Necropolă ce conținea pe lângă morminte plane și } 19 \text { tumuli. A fost } \\
\text { cercetată în } 1980 \text { de către M. Brudiu. }\end{array}$ & La nord de castellum. & $\begin{array}{l}\text { Brudiu 1991, 53; } \\
\text { Brudiu 2003, 93-136, } \\
\text { nr. 237-256. }\end{array}$ \\
\hline 489 & Neprecizat & $\begin{array}{l}\text { Șendreni (com.), } \\
\text { sat Șendreni }\end{array}$ & B & & $\mathbf{F}$ & $\mathbf{T}$ & Dimensiuni: diam. 24 m, h. 0,80 m. & $\begin{array}{l}\text { Face parte dintr-un șir de } \\
\text { tumuli situați pe versantul } \\
\text { vestic al Bălții Mălina, la } \\
\text { cca } 900 \mathrm{~m} \text { de aceasta. }\end{array}$ & $\begin{array}{l}\text { Brudiu 2003, 93-136, } \\
\text { nr. } 387 .\end{array}$ \\
\hline 490 & Neprecizat & $\begin{array}{l}\text { Șendreni (com.), } \\
\text { sat Șendreni }\end{array}$ & $\mathbf{B}$ & & $\mathbf{F}$ & $\mathbf{T}$ & Dimensiuni: diam. 25 m, h. 0,90 m. & $\begin{array}{l}\text { Face parte dintr-un şir de } \\
\text { tumuli situați pe versantul } \\
\text { vestic al Bălții Mălina, la } \\
\text { cca } 900 \text { m de aceasta. }\end{array}$ & $\begin{array}{l}\text { Brudiu 2003, 93-136, } \\
\text { nr. } 386 .\end{array}$ \\
\hline 491 & Neprecizat & $\begin{array}{l}\text { Galați (mun.), } \\
\text { Blv. G. Coșbuc }\end{array}$ & B & & & & $\begin{array}{l}\text { Tumul distrus în anul 1939-1940, în zona fostului Aeroport din Galați } \\
\text { (actualmente Întreprinderea de cuie și lanțuri). S-a descoperit un } \\
\text { mormânt sarmatic din care s-a păstrat doar un vas, aflat în custodia } \\
\text { MJIG. }\end{array}$ & $\begin{array}{l}\text { Conform M. Brudiu: ,....în } \\
\text { zona fostului Aeroport } \\
\text { Galați, acum Întreprinderea } \\
\text { de cuie și lanțuri.” }\end{array}$ & $\begin{array}{l}\text { Brudiu 2003, 93-136, } \\
\text { nr. } 374 .\end{array}$ \\
\hline 492 & Neprecizat & $\begin{array}{l}\text { Liești (com.), } \\
\text { Liești }\end{array}$ & $\mathbf{B}$ & $\mathbf{C}$ & & & $\begin{array}{l}\text { Dimensiuni: diam. } 31 \mathrm{~m}, \mathrm{~h} .0,90 \mathrm{~m} \text {. Au fost descoperite două morminte, } \\
\text { unul de epoca bronzului și unul din perioada migrațiilor. }\end{array}$ & $\begin{array}{l}\text { Pe versantul vestic al văii } \\
\text { Gerului la } 1 \text { km nord-est de } \\
\text { nr. } 9 .\end{array}$ & $\begin{array}{l}\text { Brudiu 2003, 123, nr. } \\
316 .\end{array}$ \\
\hline 493 & Neprecizat & $\begin{array}{l}\text { Liești (com.), } \\
\text { Liești }\end{array}$ & $\mathbf{B}$ & $\mathbf{C}$ & & & Dimensiuni: diam. 40 m, h. 2 m. & $\begin{array}{l}\text { Pe versantul vestic al văii } \\
\text { Gerului la } 1,60 \text { km sud-est } \\
\text { de nr. } 9 \text {. }\end{array}$ & $\begin{array}{l}\text { Brudiu 2003, 121, nr. } \\
297 .\end{array}$ \\
\hline 494 & Neprecizat & $\begin{array}{l}\text { Liești (com.), } \\
\text { Liești }\end{array}$ & $\mathbf{B}$ & & & & Dimensiuni: diam. 40 m, h. 2 m. & $\begin{array}{l}\text { Pe versantul vestic al văii } \\
\text { Gerului la } 300 \text { m est de nr. } \\
10 .\end{array}$ & $\begin{array}{l}\text { Brudiu 2003, 122, nr. } \\
299 .\end{array}$ \\
\hline 495 & Neprecizat & $\begin{array}{l}\text { Pechea (com.) } \\
\text { Pechea }\end{array}$ & $\mathbf{B}$ & & & & Dimensiuni: diam. 35 m, h. 1 m. & $\begin{array}{l}\text { Pe dealul Cocorașul, la 2,50 } \\
\text { km nord-est de nr. } 9 .\end{array}$ & $\begin{array}{l}\text { Brudiu 2003, 122, nr. } \\
308\end{array}$ \\
\hline 496 & Neprecizat & $\begin{array}{l}\text { Pechea (com.), } \\
\text { Pechea }\end{array}$ & B & & & & Dimensiuni: diam. 30 m, h. 0,90 m. & $\begin{array}{l}\text { Pe dealul Cocorassul, la } 200 \\
\text { m nord de nr. } 495 .\end{array}$ & $\begin{array}{l}\text { Brudiu 2003, 122, nr. } \\
307\end{array}$ \\
\hline 497 & Neprecizat & $\begin{array}{c}\text { Pechea (com.), } \\
\text { Pechea }\end{array}$ & $\mathbf{B}$ & & & & Dimensiuni: diam. 25 m, h. 0,90 m. & $\begin{array}{l}\text { Pe dealul Cocoraşul, la } 50 \\
\text { m nord de nr. } 496 .\end{array}$ & $\begin{array}{l}\text { Brudiu 2003, 122, nr. } \\
306\end{array}$ \\
\hline 498 & Neprecizat & $\begin{array}{l}\text { Pechea (com.), } \\
\text { Pechea }\end{array}$ & B & & & & Dimensiuni: diam. 25 m, h. 0,80 m. & $\begin{array}{l}\text { Pe dealul Cocoraşul, la } 50 \\
\text { m nord de nr. } 497 \text {. }\end{array}$ & $\begin{array}{l}\text { Brudiu 2003, 122, nr. } \\
305\end{array}$ \\
\hline 499 & Neprecizat & $\begin{array}{l}\text { Pechea (com.), } \\
\text { Pechea }\end{array}$ & $\mathbf{B}$ & & & & Dimensiuni: diam. 25 m, h. 0,90 m. & $\begin{array}{l}\text { Pe dealul Cocoraşul, la } 50 \\
\text { m nord de nr. } 498 .\end{array}$ & $\begin{array}{l}\text { Brudiu 2003, 122, nr. } \\
304\end{array}$ \\
\hline 500 & Neprecizat & $\begin{array}{l}\text { Pechea (com.) } \\
\text { Pechea }\end{array}$ & B & & & & Dimensiuni: diam. 40 m, h. 1,20 m. & $\begin{array}{l}\text { Pe dealul Cocorașul, la } 900 \\
\text { m sud de nr. } 495 \text { și } 300 \text { m } \\
\text { est de nr. } 50 .\end{array}$ & $\begin{array}{l}\text { Brudiu 2003, 123, nr. } \\
313\end{array}$ \\
\hline
\end{tabular}




\begin{tabular}{|c|c|c|c|c|c|c|c|c|c|}
\hline $\begin{array}{l}\text { Nr. } \\
\text { crt. }\end{array}$ & Toponim & Administrativ & B & $\mathbf{C}$ & $\mathbf{F}$ & $\mathbf{T}$ & Descriere & Localizare & Bibliografie \\
\hline
\end{tabular}

\begin{tabular}{|c|c|c|c|c|c|c|c|c|}
\hline 501 & Neprecizat & $\begin{array}{l}\text { Piscu (com.), sat } \\
\quad \text { Piscu }\end{array}$ & B & $\mathbf{C}$ & $\mathbf{F}$ & Dimensiuni: diam. 40 m, h. 2 m. & $\begin{array}{l}\text { În punctul numit Odaia } \\
\text { Gerului, pe calea Copoiului, } \\
\text { situat în nordul teritoriului } \\
\text { comunei, la aprox. } 8,50 \mathrm{~km} \\
\text { nord de sat. }\end{array}$ & $\begin{array}{l}\text { Brudiu 1991, 49, nr. } \\
\text { 125; Brudiu 2003, 105, } \\
\text { nr. } 125 .\end{array}$ \\
\hline 502 & Neprecizat & $\begin{array}{l}\text { Liești (com.), } \\
\text { Liești }\end{array}$ & B & & & Dimensiuni: diam. 45 m, h. 2,50 m. & $\begin{array}{l}\text { În albia majoră a Văii } \\
\text { Gerului la vest de canal și la } \\
400 \text { m vest de nr } 10 \text {. }\end{array}$ & $\begin{array}{l}\text { Brudiu 2003, 122, nr. } \\
300 .\end{array}$ \\
\hline 503 & Neprecizat & $\begin{array}{l}\text { Liești (com.), } \\
\text { Lieşti }\end{array}$ & B & & & Dimensiuni: diam. 45 m, h. 3 m. & $\begin{array}{l}\text { În albia majoră a Văii } \\
\text { Gerului la vest de canal și la } \\
500 \mathrm{~m} \text { sud de nr } 10 .\end{array}$ & $\begin{array}{l}\text { Brudiu 2003, 122, nr. } \\
301 .\end{array}$ \\
\hline 504 & Neprecizat & $\begin{array}{l}\text { Liești (com.), } \\
\text { Liești }\end{array}$ & B & & & Dimensiuni: diam. 35 m, h. 2,50 m. & $\begin{array}{l}\text { În albia majoră a Văii } \\
\text { Gerului la vest de canal și la } \\
700 \mathrm{~m} \text { sud de } \mathrm{nr} 10 \text {. }\end{array}$ & $\begin{array}{l}\text { Brudiu 2003, 122, nr. } \\
302 .\end{array}$ \\
\hline 505 & Neprecizat & $\begin{array}{l}\text { Slobozia Conachi } \\
\text { (com.), Slobozia } \\
\text { Conachi }\end{array}$ & B & & $\mathbf{F}$ & Dimensiuni: diam. 25 m, h. 1 m. & $\begin{array}{l}\text { Pe dealul Copoiului la } 900 \\
\text { m sud de nr. } 62 \text {. }\end{array}$ & $\begin{array}{l}\text { Brudiu 1991, 48; } \\
\text { Brudiu 2003, 103, nr. } \\
\text { 103. }\end{array}$ \\
\hline 506 & Neprecizat & $\begin{array}{l}\text { Slobozia Conachi } \\
\text { (com.), Slobozia } \\
\text { Conachi }\end{array}$ & B & & $\mathbf{F}$ & Dimensiuni: diam. 40 m, h. 2 m. & $\begin{array}{l}\text { Pe dealul Copoiului la } 600 \\
\text { m sud de nr. } 505 .\end{array}$ & $\begin{array}{l}\text { Brudiu 1991, 48; } \\
\text { Brudiu 2003, 103, nr. } \\
104 .\end{array}$ \\
\hline 507 & Neprecizat & $\begin{array}{c}\text { Slobozia Conachi } \\
\text { (com.), Slobozia } \\
\text { Conachi }\end{array}$ & B & & $\mathbf{F}$ & Dimensiuni: diam. 25 m, h. 1 m. & $\begin{array}{l}\text { Pe dealul Copoiului la } 400 \\
\text { m sud de nr. } 506 .\end{array}$ & $\begin{array}{l}\text { Brudiu 1991, 49; } \\
\text { Brudiu 2003, 103-104, } \\
\text { nr. } 105 .\end{array}$ \\
\hline 508 & Neprecizat & $\begin{array}{l}\text { Slobozia Conachi } \\
\text { (com.), Slobozia } \\
\text { Conachi }\end{array}$ & B & & & Dimensiuni: diam. 40 m, h. 2 m. & $\begin{array}{l}\text { La sud de pădurea Bălțatu, } \\
\text { pe dealul Bălțatu. }\end{array}$ & $\begin{array}{l}\text { Brudiu 1991, 51; } \\
\text { Brudiu 2003, 109-110, } \\
\text { nr. } 166 .\end{array}$ \\
\hline 509 & Neprecizat & $\begin{array}{l}\text { Galați (mun.) } \\
\text { Barboși }\end{array}$ & B & $\mathbf{C}$ & $\mathbf{F}$ & $\begin{array}{l}\text { Necropolă ce conținea pe lângă morminte plane și } 19 \text { tumuli. A fost } \\
\text { cercetată în } 1980 \text { de către M. Brudiu. }\end{array}$ & La nord de castellum. & $\begin{array}{l}\text { Pârvan 1913, 111; } \\
\text { Brudiu 1991, 53; } \\
\text { Brudiu 2003, 93-136, } \\
\text { nr. 237-256. }\end{array}$ \\
\hline 510 & Neprecizat & $\begin{array}{l}\text { Galați (mun.) } \\
\text { Barboși }\end{array}$ & B & $\mathbf{C}$ & $\mathbf{F}$ & $\begin{array}{l}\text { Necropolă ce conținea pe lângă morminte plane și } 19 \text { tumuli. A fost } \\
\text { cercetată în } 1980 \text { de către M. Brudiu. }\end{array}$ & La nord de castellum. & $\begin{array}{l}\text { Pârvan 1913, 111; } \\
\text { Brudiu 1991, 53; } \\
\text { Brudiu 2003, 93-136, } \\
\text { nr. 237-256. }\end{array}$ \\
\hline 511 & Neprecizat & $\begin{array}{l}\text { Galați (mun.) } \\
\text { Barboși }\end{array}$ & B & $\mathbf{C}$ & $\mathbf{F}$ & $\begin{array}{l}\text { Necropolă ce conținea pe lângă morminte plane și } 19 \text { tumuli. A fost } \\
\text { cercetată în } 1980 \text { de către M. Brudiu. }\end{array}$ & La nord de castellum. & $\begin{array}{l}\text { Pârvan 1913, 111; } \\
\text { Brudiu 1991, 53; } \\
\text { Brudiu 2003, 93-136, } \\
\text { nr. 237-256. }\end{array}$ \\
\hline 512 & Neprecizat & $\begin{array}{l}\text { Galați (mun.) } \\
\text { Barboși }\end{array}$ & B & $\mathbf{C}$ & $\mathbf{F}$ & $\begin{array}{l}\text { Necropolă ce conținea pe lângă morminte plane și } 19 \text { tumuli. A fost } \\
\text { cercetată în } 1980 \text { de către M. Brudiu. }\end{array}$ & La nord de castellum. & $\begin{array}{l}\text { Pârvan 1913, 111; } \\
\text { Brudiu 1991, 53; } \\
\text { Brudiu 2003, 93-136, } \\
\text { nr. 237-256. }\end{array}$ \\
\hline
\end{tabular}




\begin{tabular}{|l|l|l|l|l|l|l|l|c|c|}
\hline $\begin{array}{l}\text { Nr. } \\
\text { crt. }\end{array}$ & Toponim & Administrativ & B & C & F & T & Descriere & Localizare & Bibliografie \\
\hline
\end{tabular}

\begin{tabular}{|c|c|c|c|c|c|c|c|c|}
\hline 513 & Neprecizat & $\begin{array}{l}\text { Galați (mun.) } \\
\text { Barboși }\end{array}$ & B & $\mathbf{C}$ & $\mathbf{F}$ & $\begin{array}{l}\text { Necropolă ce conținea pe lângă morminte plane și } 19 \text { tumuli. A fost } \\
\text { cercetată în } 1980 \text { de către M. Brudiu. }\end{array}$ & La nord de castellum. & $\begin{array}{l}\text { Pârvan 1913, 111; } \\
\text { Brudiu 1991, 53; } \\
\text { Brudiu 2003, 93-136, } \\
\text { nr. 237-256. }\end{array}$ \\
\hline 514 & Neprecizat & $\begin{array}{l}\text { Galați (mun.), } \\
\text { Barboși }\end{array}$ & $\mathbf{B}$ & $\mathbf{C}$ & $\mathbf{F}$ & $\begin{array}{l}\text { Necropolă ce conținea pe lângă morminte plane şi } 19 \text { tumuli. A fost } \\
\text { cercetată în } 1980 \text { de către M. Brudiu. }\end{array}$ & La nord de castellum. & $\begin{array}{l}\text { Pârvan 1913, 111; } \\
\text { Brudiu 1991, 53; } \\
\text { Brudiu 2003, 93-136, } \\
\text { nr. 237-256. }\end{array}$ \\
\hline 515 & Neprecizat & $\begin{array}{l}\text { Galați (mun.), } \\
\text { Barboși }\end{array}$ & $\mathbf{B}$ & $\mathbf{C}$ & $\mathbf{F}$ & $\begin{array}{l}\text { Necropolă ce conținea pe lângă morminte plane și } 19 \text { tumuli. A fost } \\
\text { cercetată în } 1980 \text { de către M. Brudiu. }\end{array}$ & La nord de castellum. & $\begin{array}{l}\text { Pârvan 1913, 111; } \\
\text { Brudiu 1991, 53; } \\
\text { Brudiu 2003, 93-136, } \\
\text { nr. 237-256. }\end{array}$ \\
\hline 516 & Neprecizat & $\begin{array}{l}\text { Galați (mun.), } \\
\text { Barboși }\end{array}$ & B & $\mathbf{C}$ & $\mathbf{F}$ & $\begin{array}{l}\text { Necropolă ce conținea pe lângă morminte plane și } 19 \text { tumuli. A fost } \\
\text { cercetată în } 1980 \text { de către M. Brudiu. }\end{array}$ & La nord de castellum. & $\begin{array}{l}\text { Pârvan 1913, 111; } \\
\text { Brudiu 1991, 53; } \\
\text { Brudiu 2003, 93-136, } \\
\text { nr. 237-256. }\end{array}$ \\
\hline 517 & Neprecizat & $\begin{array}{l}\text { Galați (mun.) } \\
\text { Barboși }\end{array}$ & B & $\mathbf{C}$ & $\mathbf{F}$ & $\begin{array}{l}\text { Necropolă ce conținea pe lângă morminte plane şi } 19 \text { tumuli. A fost } \\
\text { cercetată în } 1980 \text { de către M. Brudiu. }\end{array}$ & La nord de castellum. & $\begin{array}{l}\text { Pârvan 1913, 111; } \\
\text { Brudiu 1991, 53; } \\
\text { Brudiu 2003, 93-136, } \\
\text { nr. 237-256. }\end{array}$ \\
\hline 518 & Neprecizat & $\begin{array}{l}\text { Galați (mun.) } \\
\text { Barboși }\end{array}$ & $\mathbf{B}$ & & & $\begin{array}{l}\text { În anul } 1978 \text { pe platoul de la Tirighina a fost descoperit un tumul cu } \\
\text { ringuri concentrice din piatră. Tumulul avea depuse în interior mai multe } \\
\text { morminte, de incinerație și de inhumație, dintre care unul în sicriu de } \\
\text { lemn. Inventarul acestuia din urmă este spectaculos: o fibulă din aur de } \\
\text { tipul „cu bulbi de ceapă” la capetele resortului, trei monede din bronz din } \\
\text { timpul lui Claudius Gothicus ( } 268-270 \text { ), un pahar din sticlă, un tub din } \\
\text { corn, elemente de sandale din bronz, un opaiț, o cățuie și trei amfore. }\end{array}$ & $\begin{array}{l}\text { Tumulul este localizat pe } \\
\text { pantele vestice ale platoului } \\
\text { Tirighina la nord-vest de } \\
\text { castru. }\end{array}$ & $\begin{array}{l}\text { Dragomir 1981, 73- } \\
\text { 114; Croitoru 2013, 94- } \\
95 .\end{array}$ \\
\hline 519 & Neprecizat & $\begin{array}{l}\text { Galați (mun.) } \\
\text { Barboși }\end{array}$ & B & & & $\begin{array}{l}\text { Necropolă ce conținea pe lângă morminte plane și } 19 \text { tumuli. A fost } \\
\text { cercetată în } 1980 \text { de către M. Brudiu. }\end{array}$ & La nord-est de castellum. & $\begin{array}{l}\text { Pârvan 1914, 112; Sanie } \\
\text { 1981, 82-83; Oța 2013, } \\
\text { 133. }\end{array}$ \\
\hline 520 & Neprecizat & $\begin{array}{l}\text { Galați (mun.), } \\
\text { Barboși }\end{array}$ & B & & & $\begin{array}{l}\text { În anul } 1904 \text { a fost descoperit întâmplător, cu prilejul unor amenajări } \\
\text { militare, un tumul cu înmormântare în sarcofag din epoca romană. } \\
\text { Singura mărturie o reprezintă desenele arhitectului militar E. Honzik, } \\
\text { reproduse ulterior de V. Pârvan, care redau sumar sarcofagul și } \\
\text { inventarul acestuia. Sarcofagul era din piatră realizat, conform } \\
\text { inscripției, în Asia Mică în timpul asiarchului Alfius Modestus. } \\
\text { Inventarul era format din armament roman şi mai multe vase romane } \\
\text { specifice unor contexte asemenea. }\end{array}$ & $\begin{array}{l}\text { Tumulul este localizat pe } \\
\text { pantele vestice ale platoului } \\
\text { Tirighina la nord-est de } \\
\text { castellum. }\end{array}$ & $\begin{array}{l}\text { Dumitrescu 1911, } 45 \\
\text { (Al. T. Dumitrescu în } \\
\text { BCMI, IV, 1911, 45); } \\
\text { Croitoru 2013, } 94 .\end{array}$ \\
\hline
\end{tabular}




\begin{tabular}{|c|c|c|c|c|c|c|c|c|c|}
\hline $\begin{array}{l}\text { Nr. } \\
\text { crt. }\end{array}$ & Toponim & Administrativ & B & $\mathbf{C}$ & $\mathbf{F}$ & $\mathbf{T}$ & Descriere & Localizare & Bibliografie \\
\hline
\end{tabular}

\begin{tabular}{|c|c|c|c|c|c|c|c|}
\hline 521 & Neprecizat & $\begin{array}{l}\text { Galați (mun.), } \\
\text { Barboși }\end{array}$ & B & & $\begin{array}{l}\text { Tumul de mici dimensiuni (Dmax= } 5 \mathrm{~m} ; \mathrm{H}=0,50 \mathrm{~m} \text { ) cercetat în } \\
\text { campaniile } 1976-1979 \text {, care conținea } 11 \text { morminte, două de incinerație } \\
\text { și nouă de inhumație. Tumulul dispunea de amenajarea a două ringuri } \\
\text { concentrice de pietre, unul pe diametrul maxim, iar al doilea pe } \\
\text { diametrul de } 2,70 \mathrm{~m} \text {. }\end{array}$ & $\begin{array}{l}\text { În partea de vest a castrului } \\
\text { de la Barboși, în interiorul } \\
\text { aşezării civile, pe panta } \\
\text { abruptă a dealului. În } \\
\text { imediata apropiere se afla } \\
\text { Întreprinderea de } \\
\text { Sistematizare Automatizare } \\
\text { Feroviară din gara Bărboși. }\end{array}$ & $\begin{array}{l}\text { Dragomir 1996, 536- } \\
566 .\end{array}$ \\
\hline 522 & Neprecizat & Galați (mun.) & B & C & $\begin{array}{l}\text { Tumulul este menționat, fără alte precizări, într-o hotarnică din anul } \\
1884 .\end{array}$ & $\begin{array}{l}\text { La } 50 \text { m nord de Piața } \\
\text { Energiei și la } 2 \mathrm{~km} \text { est de } \\
\text { intrarea Combinatul } \\
\text { Siderurgic Galați. }\end{array}$ & $\begin{array}{l}\text { Arhiva Naționala fil. } \\
\text { Galați, dos. 481; } \\
\text { Brudiu 2003, 93-136, } \\
\text { nr. } 366 . \\
\end{array}$ \\
\hline 523 & Neprecizat & Galații (mun.) & B & & $\begin{array}{l}\text { Tumulul este menționat, fără alte precizări, într-o hotarnică din anul } \\
1884 .\end{array}$ & $\begin{array}{l}\text { La } 100 \mathrm{~m} \text { nord de Piața } \\
\text { Energiei și la } 2 \mathrm{~km} \text { est de } \\
\text { intrarea Combinatul } \\
\text { Siderurgic Galați. }\end{array}$ & $\begin{array}{l}\text { Arhiva Naționala fil. } \\
\text { Galați, dos. 481; } \\
\text { Brudiu 2003, 93-136, } \\
\text { nr. } 367 . \\
\end{array}$ \\
\hline 524 & Neprecizat & Galați (mun.) & B & & $\begin{array}{l}\text { Dimensiuni: diam. } 30 \mathrm{~m} \text {, h. } 1 \mathrm{~m} \text {. A fost construită o casa deasupra, } \\
\text { ulterior fiind demantelat. }\end{array}$ & $\begin{array}{l}\text { La est de şoseaua Galați- } \\
\text { Oancea. }\end{array}$ & $\begin{array}{l}\text { Brudiu 1991, 53; } \\
\text { Brudiu 2003, 93-136, } \\
\text { nr. } 232 .\end{array}$ \\
\hline 525 & Neprecizat & Galați (mun.) & B & & $\begin{array}{l}\text { Dimensiuni: diam. } 26 \mathrm{~m}, \text { h. } 0,80 \mathrm{~m} \text {. Tumulul a fost distrus de amenajarea } \\
\text { unui drum pentru cariera de loess de pe faleza Brateșului. }\end{array}$ & $\begin{array}{l}\text { La } 200 \text { m nord de școala din } \\
\text { cartierul Traian Nord. }\end{array}$ & $\begin{array}{l}\text { Brudiu 1991, 53; } \\
\text { Brudiu 2003, 93-136, } \\
\text { nr. } 233 .\end{array}$ \\
\hline 526 & Neprecizat & $\begin{array}{l}\text { Șendreni (com.), } \\
\text { sat Șendreni }\end{array}$ & B & & $\begin{array}{l}\text { Un tumul (diametru de cca } 20 \text { m şi o înălțime păstrată de cca } 1 \mathrm{~m} \text { ), } \\
\text { parțial distrus, a fost cercetat în cadrul unei săpături arheologice de } \\
\text { salvare în anul 1974. Săpăturile au fost efectuate de I. Limbidis care a } \\
\text { recuperat oseminte umane cu ocru și un inventar format din: un vas de } \\
\text { lut miniatural, patru mărgele tubulare din foiță de bronz, patru mărgele } \\
\text { din cochilii de Dentalium şi o microlită de silex. Tipologic mormântul se } \\
\text { încadrează din punct de vedere cronologic în perioada bronzului } \\
\text { timpuriu. }\end{array}$ & $\begin{array}{l}\text { În zona fostei Stațiuni de } \\
\text { Mecanizare a Agriculturii } \\
\text { (SMA), la est de comună, în } \\
\text { imediata apropiere a } \\
\text { drumului național Galați- } \\
\text { Brăila. }\end{array}$ & $\begin{array}{l}\text { Dragomir 1976, 53-60; } \\
\text { Dragomir 1996, 318- } \\
\text { 319; Brudiu 2003, 93- } \\
\text { 136, nr. } 408 .\end{array}$ \\
\hline 527 & Neprecizat & $\begin{array}{l}\text { Șendreni (com.), } \\
\text { sat Șendreni }\end{array}$ & B & & $\begin{array}{l}\text { În anul } 1955 \text { a fost descoperit un tumul ce conținea un mormânt } \\
\text { sarmatic. Dimensiunile acestuia erau de } 32 \mathrm{~m}, \mathrm{~h} .1,20 \mathrm{~m} \text {. Orientarea } \\
\text { mormântului era nord-sud, iar craniul prezenta urme de deformare. } \\
\text { Inventarul este bogat și specific mormintelor sarmatice: trei vase } \\
\text { ceramice din ceramică fină aşezate în zona craniului, două căni ceramice } \\
\text { umplute cu cereale dispuse la picioarele defunctului, o oglindă din bronz } \\
\text { cu tamga, un clopoțel din bronz, } 26 \text { de mărgele (din sticlă, os, chihlimbar } \\
\text { și bronz), o pereche de cercei, trei fibule fragmentare și câteva brățări } \\
\text { fragmentare descoperite în zona picioarelor. }\end{array}$ & $\begin{array}{l}\text { În zona fostei Stațiuni de } \\
\text { Mecanizare a Agriculturii } \\
\text { (SMA), la est de comună, la } \\
100 \text { m de șoseaua Galați- } \\
\text { Brăila. }\end{array}$ & $\begin{array}{l}\text { I.T. Dragomir, Rev. } \\
\text { Muz. II, nr. 4, 1965, } \\
\text { 363-365; Idem, în } \\
\text { Danubius XVI, 1994, } \\
\text { 633-639; Brudiu 2003, } \\
\text { 93-136, nr. 409. }\end{array}$ \\
\hline 528 & Neprecizat & Galați (mun.) & B & & $\begin{array}{l}\text { Dimensiuni: diam. } 24 \text { m, h. } 1 \text { m. A fost cercetată în } 1970 \text { de către I. } \\
\text { Limbidis, care a scos la iveală un mormânt de epocă romană ce conținea, } \\
\text { drept inventar, urme de la un scut (săpături inedite). }\end{array}$ & $\begin{array}{l}\text { În partea de nord a } \\
\text { teritoriului Municipiului } \\
\text { Galați, la } 1,50 \text { km vest de } \\
\text { Movila Tăiată (nr. 457). } \\
\end{array}$ & $\begin{array}{l}\text { Brudiu 1991, 53; } \\
\text { Brudiu 2003, 93-136, } \\
\text { nr. } 234 .\end{array}$ \\
\hline
\end{tabular}




\begin{tabular}{|c|c|c|c|c|c|c|c|c|c|}
\hline $\begin{array}{l}\text { Nr. } \\
\text { crt. }\end{array}$ & Toponim & Administrativ & B & $\mathbf{C}$ & $\mathbf{F}$ & $\mathbf{T}$ & Descriere & Localizare & Bibliografie \\
\hline
\end{tabular}

\begin{tabular}{|c|c|c|c|c|c|c|}
\hline 529 & Neprecizat & Galați (mun.) & $\mathbf{B}$ & Dimensiuni: diam. 30 m, h. 1,20 m. & $\begin{array}{l}\text { În partea de nord a } \\
\text { teritoriului Municipiului } \\
\text { Galați, la } 1,50 \mathrm{~km} \text { sud de nr. } \\
528 \text {. }\end{array}$ & $\begin{array}{l}\text { Brudiu 1991, 53; } \\
\text { Brudiu 2003, 93-136, } \\
\text { nr. } 235 .\end{array}$ \\
\hline 530 & Neprecizat & Galați (mun.) & B & $\begin{array}{l}\text { Un grup de } 15 \text { tumuli menționați într-o hotărnicie din anul 1819, astăzi } \\
\text { dispăruți. Aceștia erau poziționați în linie dreaptă, pe direcția N-S, } \\
\text { începând din zona Trustului de Construcții (fostul Regiment } 11 \text { Siret), pe } \\
\text { traseul Blv. G. Coșbuc, până la Bariera Traian. }\end{array}$ & $\begin{array}{l}\text { Poziționați în linie începând } \\
\text { de la actualul Trust de } \\
\text { Construcții, pe traseul Bd. } \\
\text { G. Coșbuc, până la Bariera } \\
\text { Traian. }\end{array}$ & $\begin{array}{l}\text { Brudiu 2003, 93-136, } \\
\text { nr. 368-385. }\end{array}$ \\
\hline 531 & Neprecizat & Galați (mun.) & $\mathbf{B}$ & $\begin{array}{l}\text { Un grup de } 15 \text { tumuli menționați într-o hotărnicie din anul 1819, astăzi } \\
\text { dispăruți. Aceștia erau poziționați în linie dreaptă, pe direcția N-S, } \\
\text { începând din zona Trustului de Construcții (fostul Regiment } 11 \text { Siret), pe } \\
\text { traseul Blv. G. Coşbuc, până la Bariera Traian. }\end{array}$ & $\begin{array}{l}\text { Poziționați în linie începând } \\
\text { de la actualul Trust de } \\
\text { Construcții, pe traseul Bd. } \\
\text { G. Coşbuc, până la Bariera } \\
\text { Traian. }\end{array}$ & $\begin{array}{l}\text { Brudiu 2003, 93-136, } \\
\text { nr. 368-385. }\end{array}$ \\
\hline 532 & Neprecizat & Galați (mun.) & B & $\begin{array}{l}\text { Un grup de } 15 \text { tumuli menționați într-o hotărnicie din anul 1819, astăzi } \\
\text { dispăruți. Aceștia erau poziționați în linie dreaptă, pe direcția N-S, } \\
\text { începând din zona Trustului de Construcții (fostul Regiment } 11 \text { Siret), pe } \\
\text { traseul Blv. G. Coşbuc, până la Bariera Traian. }\end{array}$ & $\begin{array}{l}\text { Poziționați în linie începând } \\
\text { de la actualul Trust de } \\
\text { Construcții, pe traseul Bd. } \\
\text { G. Coşbuc, până la Bariera } \\
\text { Traian. }\end{array}$ & $\begin{array}{l}\text { Brudiu 2003, 93-136, } \\
\text { nr. 368-385. }\end{array}$ \\
\hline 533 & Neprecizat & Galați (mun.) & $\mathbf{B}$ & $\begin{array}{l}\text { Un grup de } 15 \text { tumuli menționați într-o hotărnicie din anul 1819, astăzi } \\
\text { dispăruți. Aceștia erau poziționați în linie dreaptă, pe direcția N-S, } \\
\text { începând din zona Trustului de Construcții (fostul Regiment } 11 \text { Siret), pe } \\
\text { traseul Blv. G. Coșbuc, până la Bariera Traian. }\end{array}$ & $\begin{array}{l}\text { Poziționați în linie începând } \\
\text { de la actualul Trust de } \\
\text { Construcții, pe traseul Bd. } \\
\text { G. Coşbuc, până la Bariera } \\
\text { Traian. }\end{array}$ & $\begin{array}{l}\text { Brudiu 2003, 93-136, } \\
\text { nr. 368-385. }\end{array}$ \\
\hline 534 & Neprecizat & Galați (mun.) & $\mathbf{B}$ & $\begin{array}{l}\text { Un grup de } 15 \text { tumuli menționați într-o hotărnicie din anul 1819, astăzi } \\
\text { dispăruți. Aceștia erau poziționați în linie dreaptă, pe direcția N-S, } \\
\text { începând din zona Trustului de Construcții (fostul Regiment } 11 \text { Siret), pe } \\
\text { traseul Blv. G. Coșbuc, până la Bariera Traian. }\end{array}$ & $\begin{array}{l}\text { Poziționați în linie începând } \\
\text { de la actualul Trust de } \\
\text { Construcții, pe traseul Bd. } \\
\text { G. Coşbuc, până la Bariera } \\
\text { Traian. }\end{array}$ & $\begin{array}{l}\text { Brudiu 2003, 93-136, } \\
\text { nr. 368-385. }\end{array}$ \\
\hline 535 & Neprecizat & Galați (mun.) & B & $\begin{array}{l}\text { Un grup de } 15 \text { tumuli menționați într-o hotărnicie din anul 1819, astăzi } \\
\text { dispăruți. Aceștia erau poziționați în linie dreaptă, pe direcția N-S, } \\
\text { începând din zona Trustului de Construcții (fostul Regiment } 11 \text { Siret), pe } \\
\text { traseul Blv. G. Coșbuc, până la Bariera Traian. }\end{array}$ & $\begin{array}{l}\text { Poziționați în linie începând } \\
\text { de la actualul Trust de } \\
\text { Construcții, pe traseul Bd. } \\
\text { G. Coşbuc, până la Bariera } \\
\text { Traian. }\end{array}$ & $\begin{array}{l}\text { Brudiu 2003, 93-136, } \\
\text { nr. 368-385. }\end{array}$ \\
\hline 536 & Neprecizat & Galați (mun.) & $\mathbf{B}$ & $\begin{array}{l}\text { Un grup de } 15 \text { tumuli menționați într-o hotărnicie din anul 1819, astăzi } \\
\text { dispăruți. Aceștia erau poziționați în linie dreaptă, pe direcția N-S, } \\
\text { începând din zona Trustului de Construcții (fostul Regiment } 11 \text { Siret), pe } \\
\text { traseul Blv. G. Coşbuc, până la Bariera Traian. }\end{array}$ & $\begin{array}{l}\text { Poziționați în linie începând } \\
\text { de la actualul Trust de } \\
\text { Construcții, pe traseul Bd. } \\
\text { G. Coşbuc, până la Bariera } \\
\text { Traian. }\end{array}$ & $\begin{array}{l}\text { Brudiu 2003, 93-136, } \\
\text { nr. 368-385. }\end{array}$ \\
\hline 537 & Neprecizat & Galați (mun.) & $\mathbf{B}$ & $\begin{array}{l}\text { Un grup de } 15 \text { tumuli menționați într-o hotărnicie din anul 1819, astăzi } \\
\text { dispăruți. Aceștia erau poziționați în linie dreaptă, pe direcția N-S, } \\
\text { începând din zona Trustului de Construcții (fostul Regiment } 11 \text { Siret), pe } \\
\text { traseul Blv. G. Coșbuc, până la Bariera Traian. }\end{array}$ & $\begin{array}{l}\text { Poziționați în linie începând } \\
\text { de la actualul Trust de } \\
\text { Construcții, pe traseul Bd. } \\
\text { G. Coșbuc, până la Bariera } \\
\text { Traian. }\end{array}$ & $\begin{array}{l}\text { Brudiu 2003, 93-136, } \\
\text { nr. 368-385. }\end{array}$ \\
\hline
\end{tabular}




\begin{tabular}{|c|c|c|c|c|c|c|c|c|c|}
\hline $\begin{array}{l}\text { Nr. } \\
\text { crt. }\end{array}$ & Toponim & Administrativ & B & C & F & T & Descriere & Localizare & Bibliografie \\
\hline
\end{tabular}

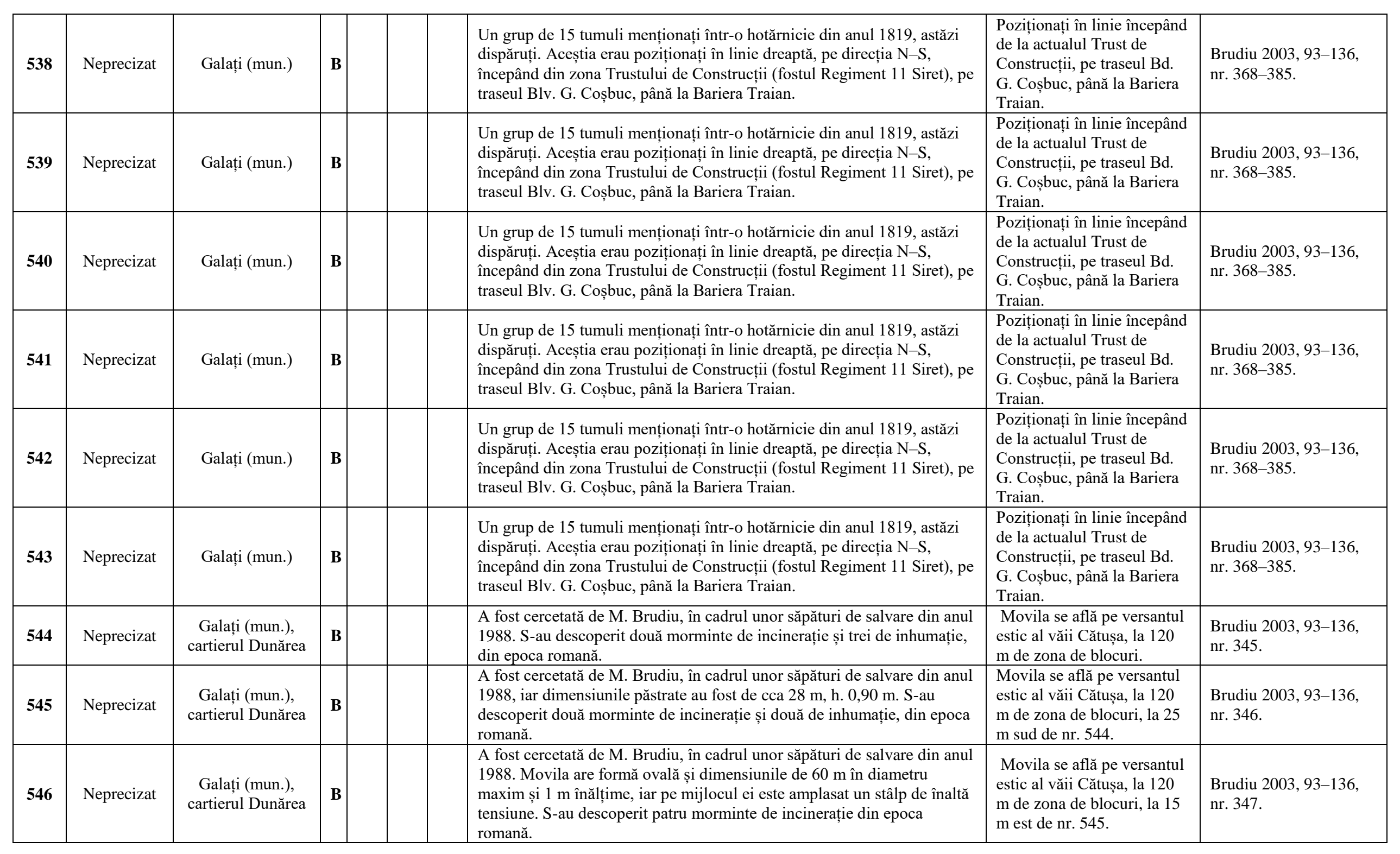




\begin{tabular}{|l|l|l|l|l|l|l|l|c|c|}
\hline $\begin{array}{l}\text { Nr. } \\
\text { crt. }\end{array}$ & Toponim & Administrativ & B & C & F & T & Descriere & Localizare & Bibliografie \\
\hline
\end{tabular}

\begin{tabular}{|c|c|c|c|c|c|c|c|c|}
\hline 547 & Neprecizat & $\begin{array}{l}\text { Galați (mun.), } \\
\text { cartierul Dunărea }\end{array}$ & B & & & $\begin{array}{l}\text { A fost cercetată de M. Brudiu, în cadrul unor săpături de salvare din anul } \\
1988 \text {, iar dimensiunile la momentul acela au fost de } 30 \text { m, h. } 0,80 \text { m. S- } \\
\text { au descoperit două morminte de incinerație și trei morminte de } \\
\text { inhumație, din epoca romană. Mormintele de inhumație erau de copii, } \\
\text { acestea dispuneau fiecare de nișă laterală. }\end{array}$ & $\begin{array}{l}\text { Movila se află pe versantul } \\
\text { estic al văii Cătușa, la } 120 \\
\text { m de zona de blocuri, la } 40 \\
\text { m nord de nr. } 546 .\end{array}$ & $\begin{array}{l}\text { Brudiu 2003, 93-136, } \\
\text { nr. } 348 .\end{array}$ \\
\hline 548 & Neprecizat & $\begin{array}{l}\text { Galați (mun.), } \\
\text { cartierul Dunărea }\end{array}$ & B & & & $\begin{array}{l}\text { A fost cercetată de M. Brudiu. Dimensiunile înregistrate de autorul } \\
\text { cercetărilor sunt de } 35 \mathrm{~m} \text {, h. o înălțime de } 1,20 \mathrm{~m} \text {. }\end{array}$ & $\begin{array}{l}\text { Movila se află pe versantul } \\
\text { estic al văii Cătuşa, la } 120 \\
\text { m de zona de blocuri, la } \\
\text { nord-vest de nr. } 547\end{array}$ & $\begin{array}{l}\text { Brudiu 2003, 93-136, } \\
\text { nr. } 349 .\end{array}$ \\
\hline 549 & Neprecizat & $\begin{array}{l}\text { Galați (mun.), } \\
\text { cartierul Dunărea }\end{array}$ & B & & & $\begin{array}{l}\text { A fost cercetată de M. Brudiu în anii 1981-1982 și face parte din } \\
\text { necropola mixtă a castellum-ului roman din apropiere. Dimensiuni: } \\
\text { diam. } 25 \text { m, h. o înălțime păstrată de } 1 \text { m. }\end{array}$ & $\begin{array}{l}\text { Movila se află la sud-vest } \\
\text { de cartierul Dunărea, făcând } \\
\text { parte din necropola din } \\
\text { apropierea castellum-ului. }\end{array}$ & $\begin{array}{l}\text { Brudiu 1991, 54, nr. } \\
\text { 260; Brudiu 2003, 93- } \\
\text { 136, nr. 260. Dragomir } \\
1996,391 .\end{array}$ \\
\hline 550 & Neprecizat & $\begin{array}{l}\text { Pechea (com.) } \\
\text { Pechea }\end{array}$ & B & & & Dimensiuni: diam. 30 m, h. 2 m. & $\begin{array}{l}\text { Se află la } 2 \text { km sud de nr. } \\
52 .\end{array}$ & $\begin{array}{l}\text { Brudiu 1991, 48; } \\
\text { Brudiu 2003, 101, nr. } \\
82 .\end{array}$ \\
\hline 551 & Neprecizat & $\begin{array}{l}\text { Piscu (com.), sat } \\
\text { Piscu }\end{array}$ & B & & $\mathbf{F}$ & Dimensiuni: diam. 30 m, h. 1 m. & $\begin{array}{l}\text { În zona sudică a } \\
\text { interfluviului dintre valea } \\
\text { Gerului şi valea Suhurlui. } \\
\text { La } 280 \text { m nord de calea } \\
\text { ferată şi la } 400 \text { m vest de } \\
\text { drumul DJ } 255 \text {. } \\
\end{array}$ & $\begin{array}{l}\text { Brudiu 1991, 49, nr. } \\
\text { 128; Brudiu 2003, 106, } \\
\text { nr. } 128 .\end{array}$ \\
\hline 552 & Neprecizat & $\begin{array}{l}\text { Independența } \\
\text { (com.), sat } \\
\text { Independența }\end{array}$ & B & $\mathbf{C}$ & $\mathbf{F}$ & Dimensiuni: diam. 40 m, h. 2 m. & $\begin{array}{l}\text { La } 500 \mathrm{~m} \text { vest de izvorul } \\
\text { văii Cătina. }\end{array}$ & $\begin{array}{l}\text { Brudiu 1991, 51, nr. } \\
\text { 170; Brudiu 2003, 110, } \\
\text { nr. } 170 .\end{array}$ \\
\hline 553 & Neprecizat & $\begin{array}{l}\text { Galați (mun.) } \\
\text { Barboși }\end{array}$ & B & $\mathbf{C}$ & $\mathbf{F}$ & $\begin{array}{l}\text { Necropolă ce conținea pe lângă morminte plane și } 19 \text { tumuli. A fost } \\
\text { cercetată în } 1980 \text { de către M. Brudiu. }\end{array}$ & La nord de castellum. & $\begin{array}{l}\text { Brudiu 1991, 53; } \\
\text { Brudiu 2003, 93-136, } \\
\text { nr. 237-256. }\end{array}$ \\
\hline 554 & Neprecizat & $\begin{array}{l}\text { Galați (mun.) } \\
\text { Barboși }\end{array}$ & B & $\mathbf{C}$ & $\mathbf{F}$ & $\begin{array}{l}\text { Necropolă ce conținea pe lângă morminte plane și } 19 \text { tumuli. A fost } \\
\text { cercetată în } 1980 \text { de către M. Brudiu. }\end{array}$ & La nord de castellum. & $\begin{array}{l}\text { Brudiu 1991, 53; } \\
\text { Brudiu 2003, 93-136, } \\
\text { nr. 237-256. }\end{array}$ \\
\hline 555 & Tumulul T I & $\begin{array}{l}\text { Galați (mun.), } \\
\text { Barboși }\end{array}$ & B & $\mathbf{C}$ & $\mathbf{F}$ & $\begin{array}{l}\text { Tumul cercetat în campania } 2009 \text { de către un colectiv al Muzeului de } \\
\text { Istorie Galați condus de C. Ilie. }\end{array}$ & $\begin{array}{l}\text { La nord de castellum și de } \\
\text { drumul național. }\end{array}$ & $\begin{array}{l}\text { Ilie } \text { et alii 2010, nr. 124, } \\
265-266 .\end{array}$ \\
\hline
\end{tabular}


alba 


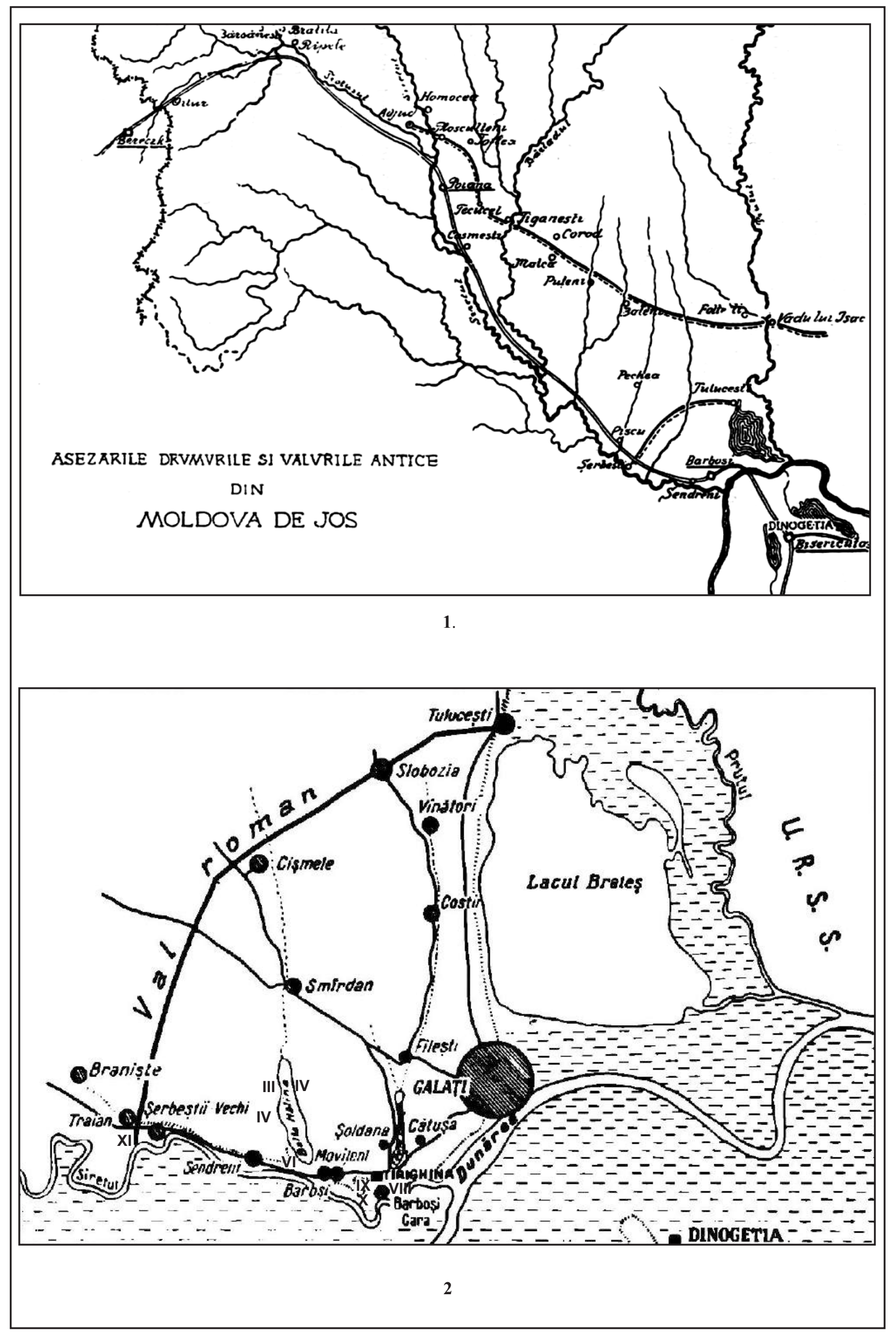




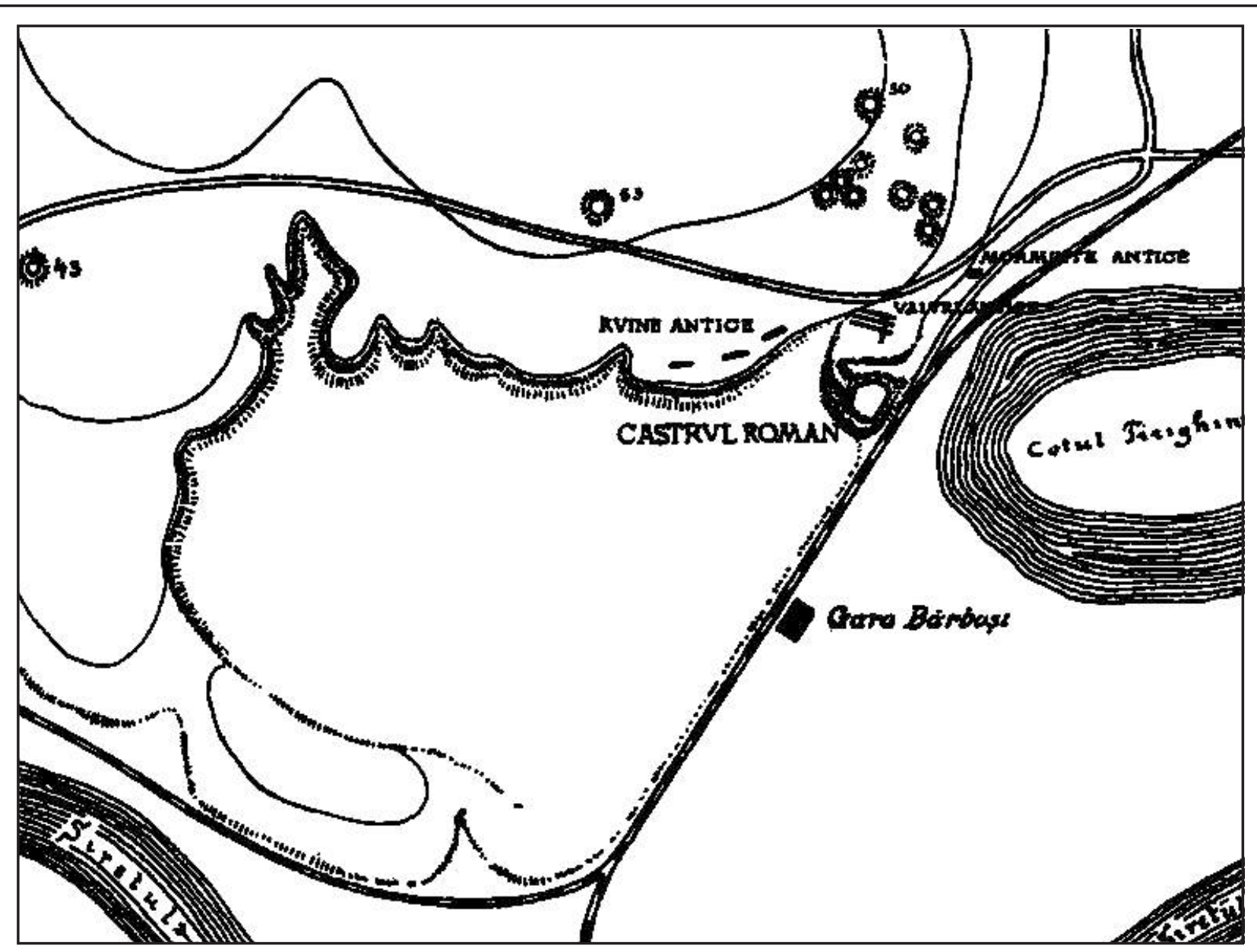

1

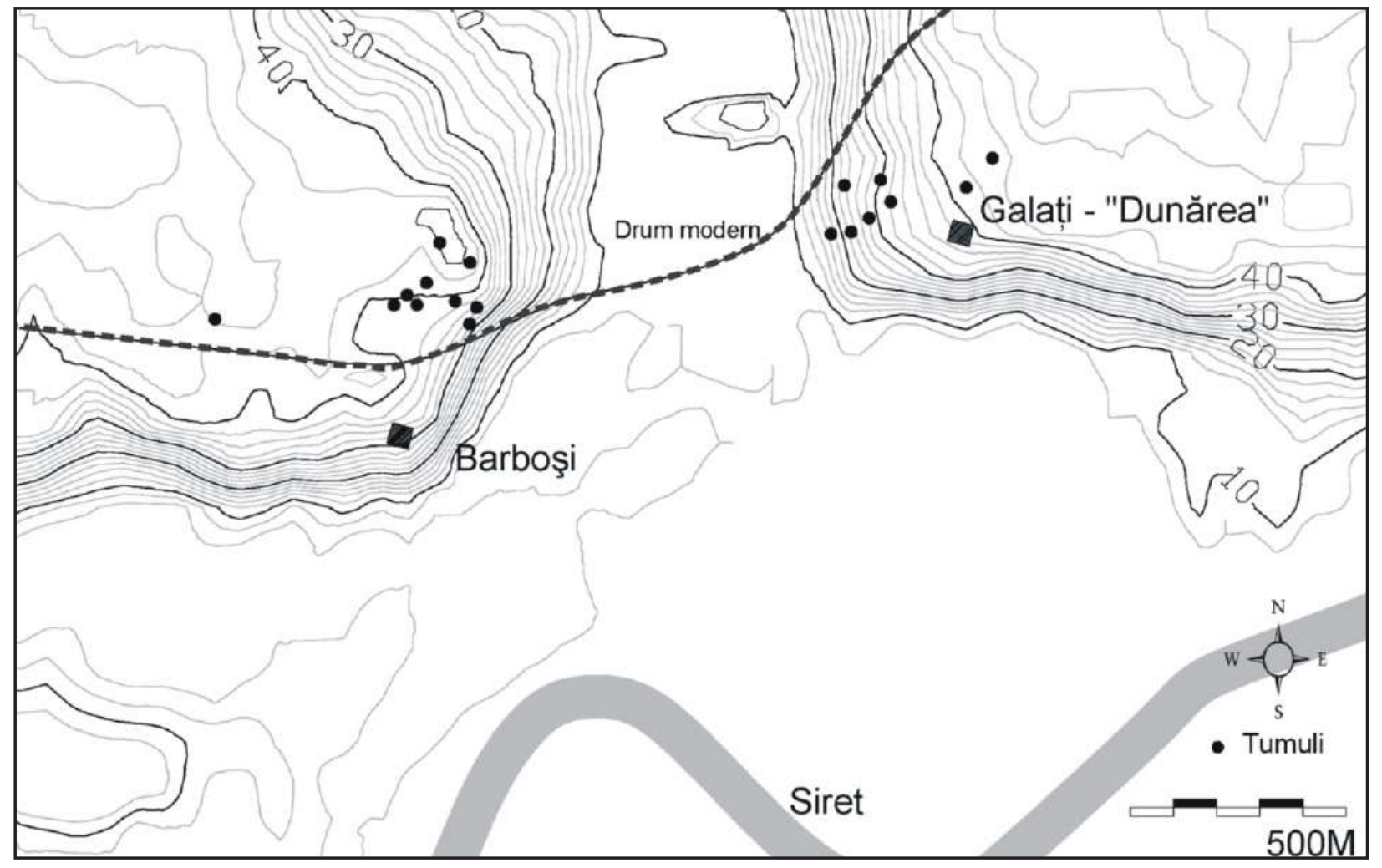




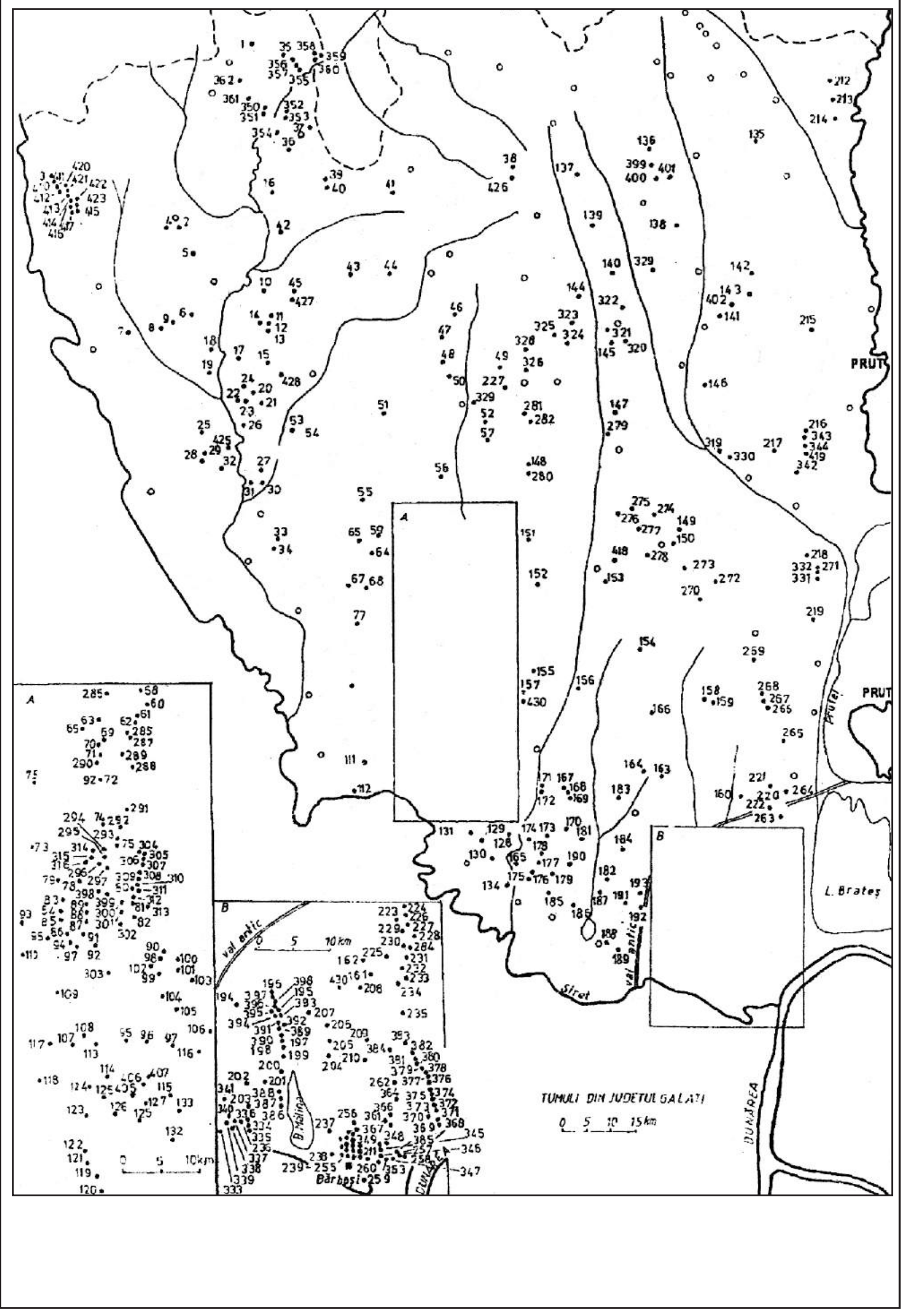




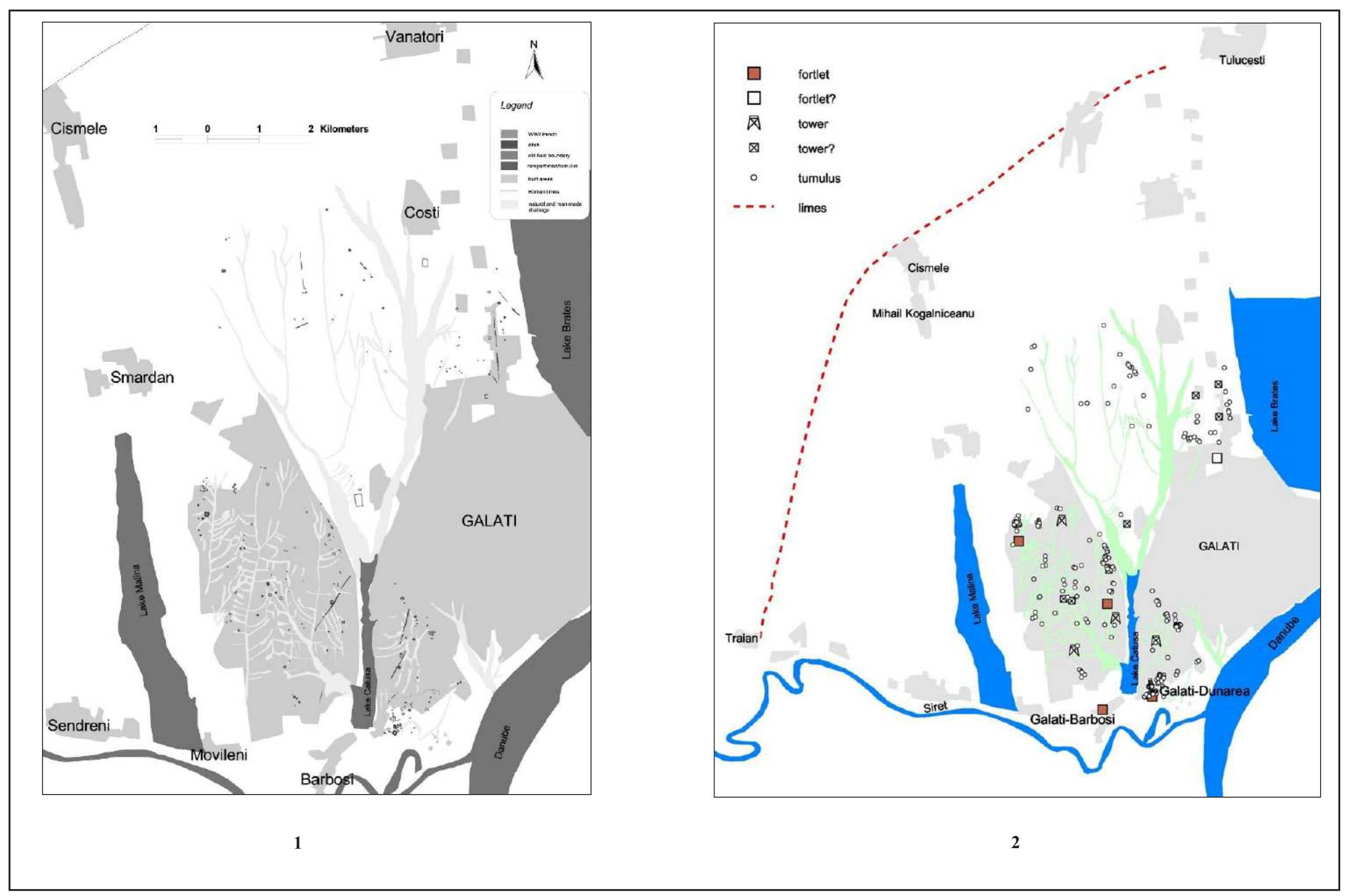




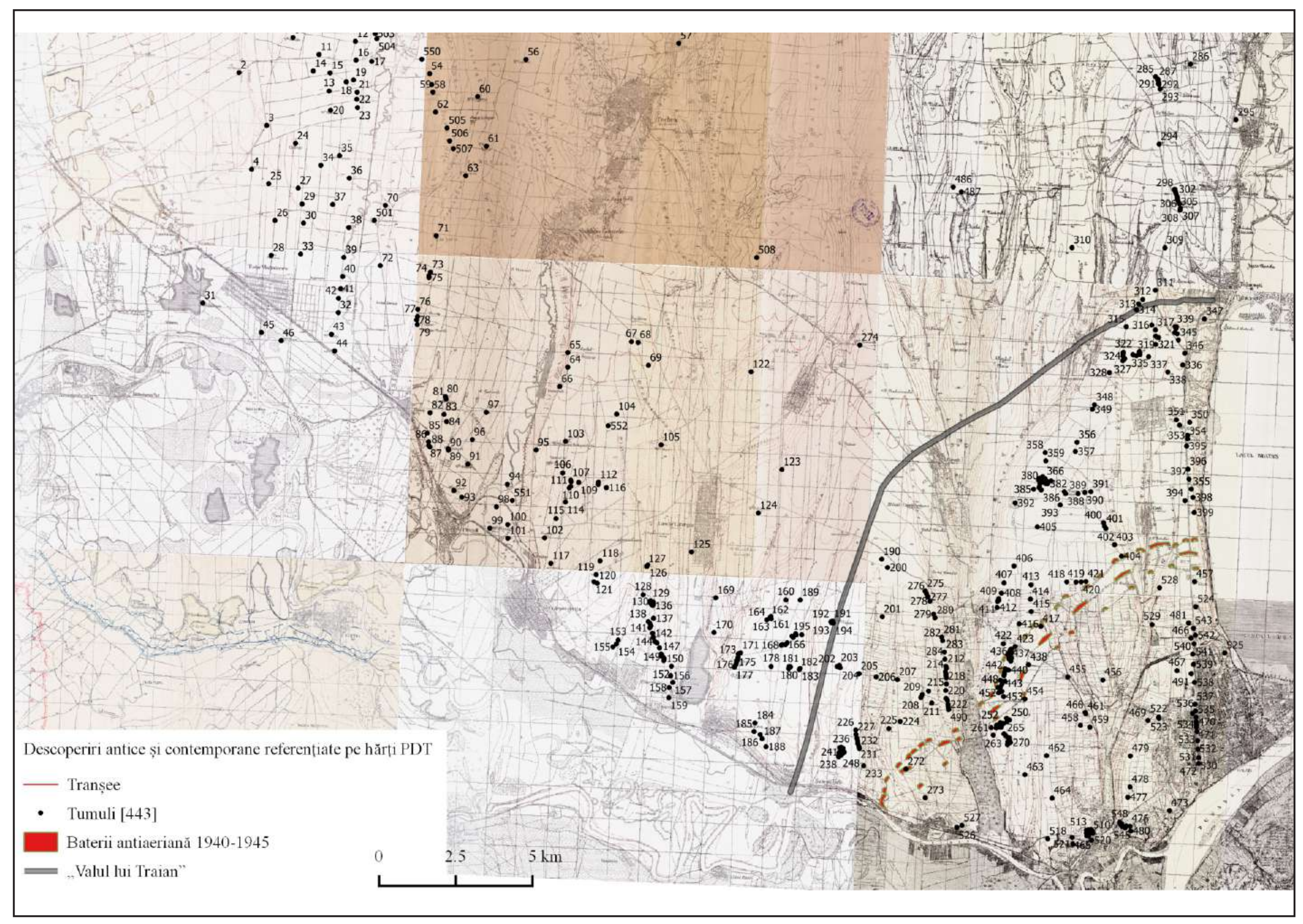




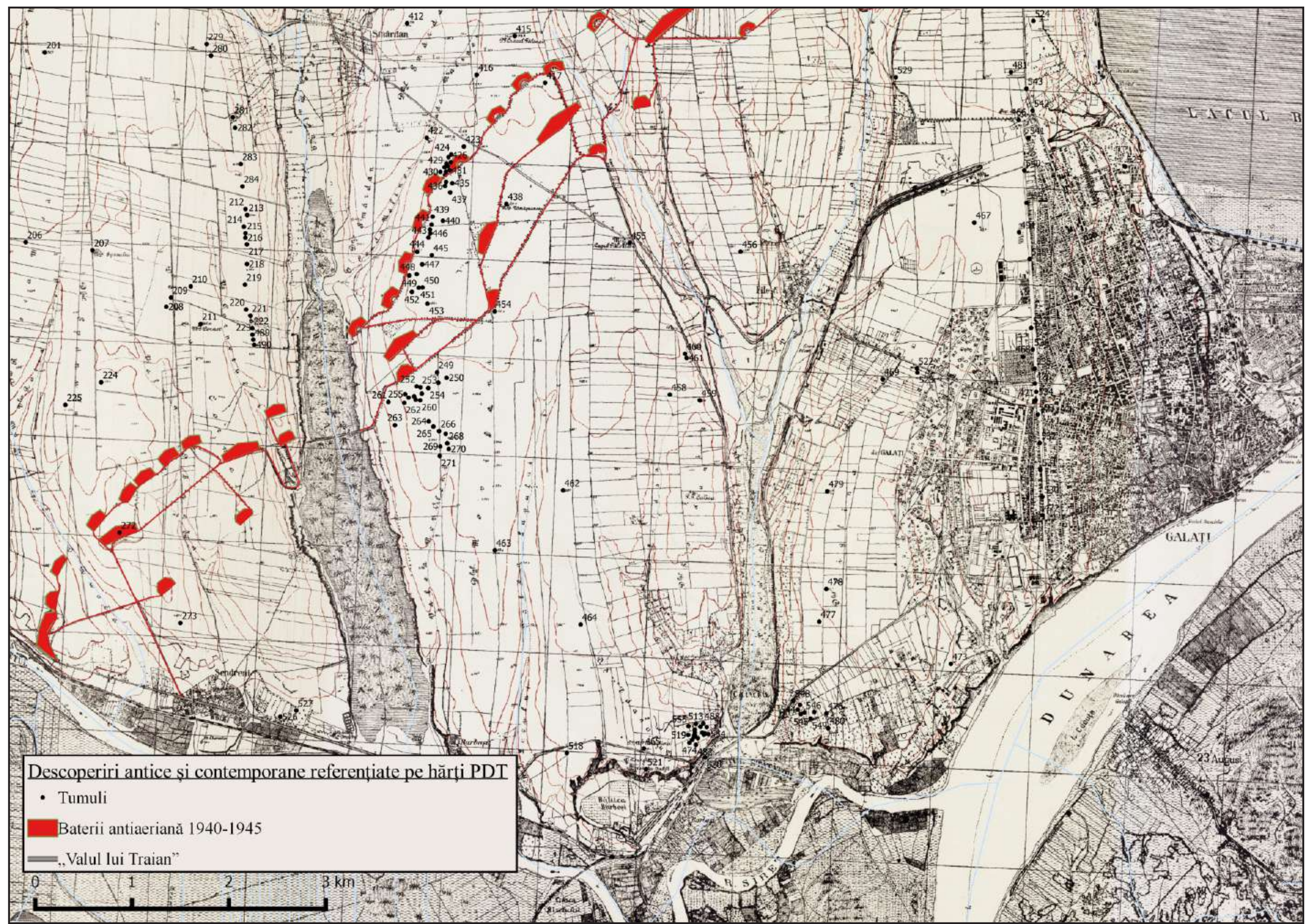

PI. VI 


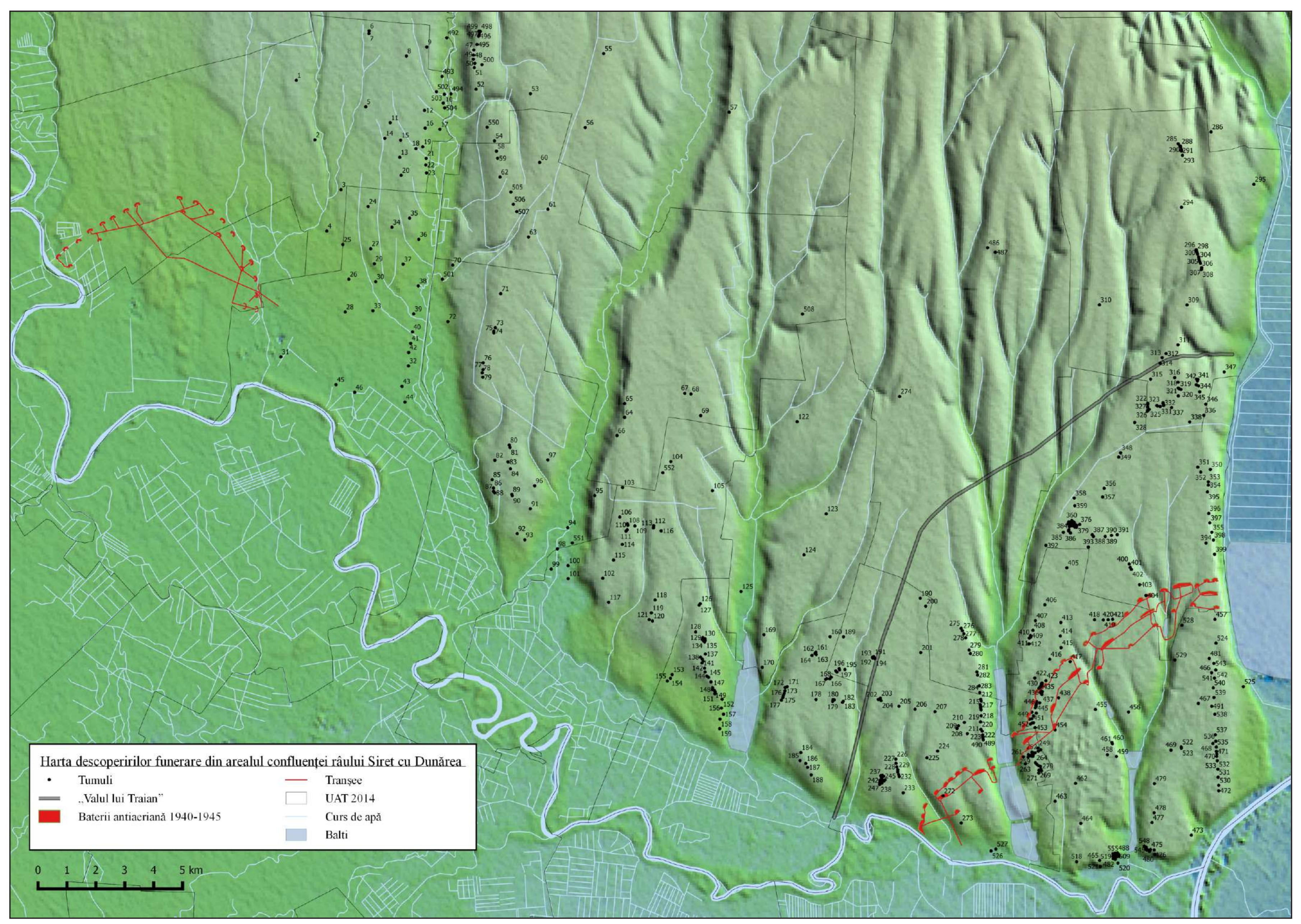




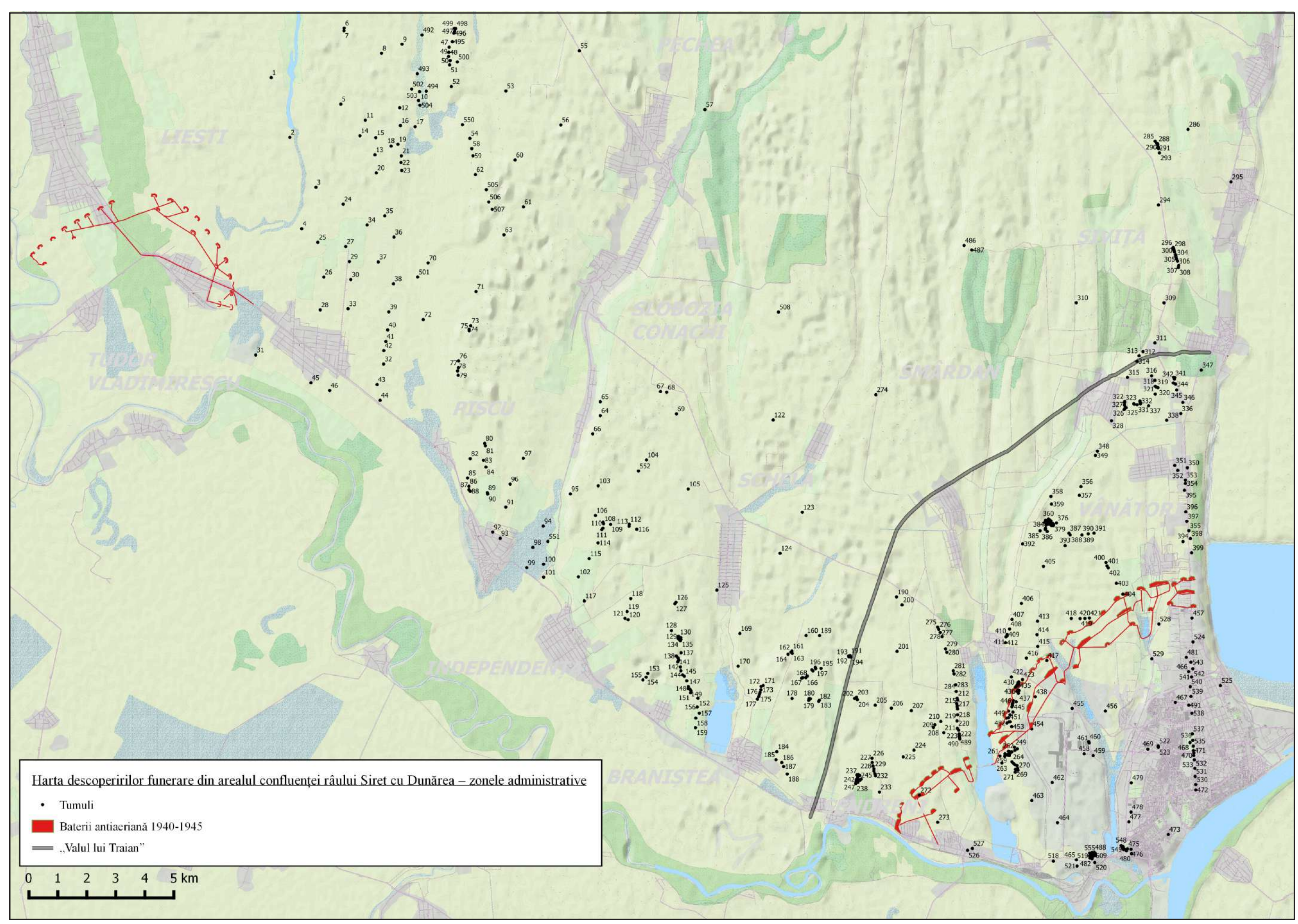




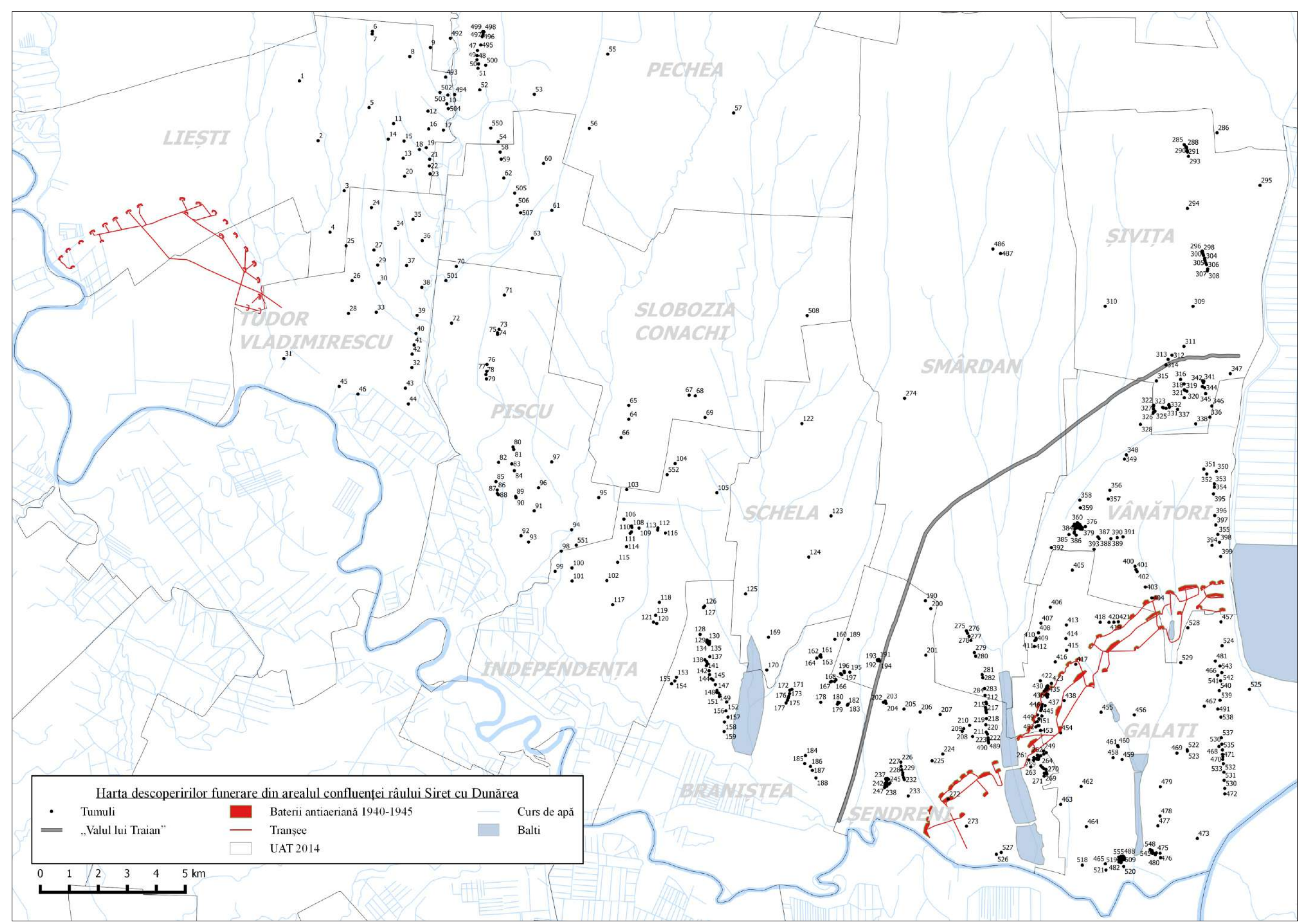




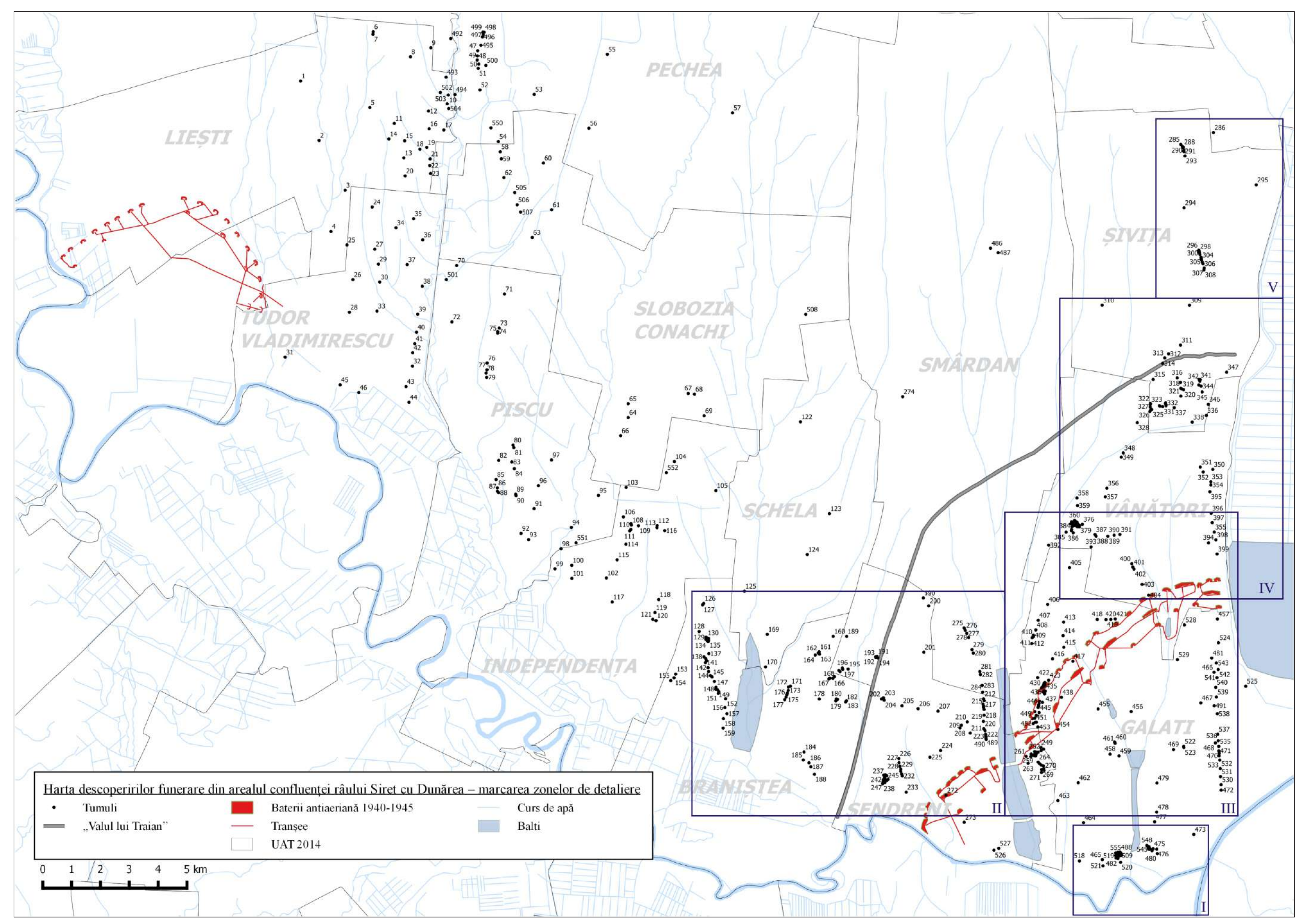




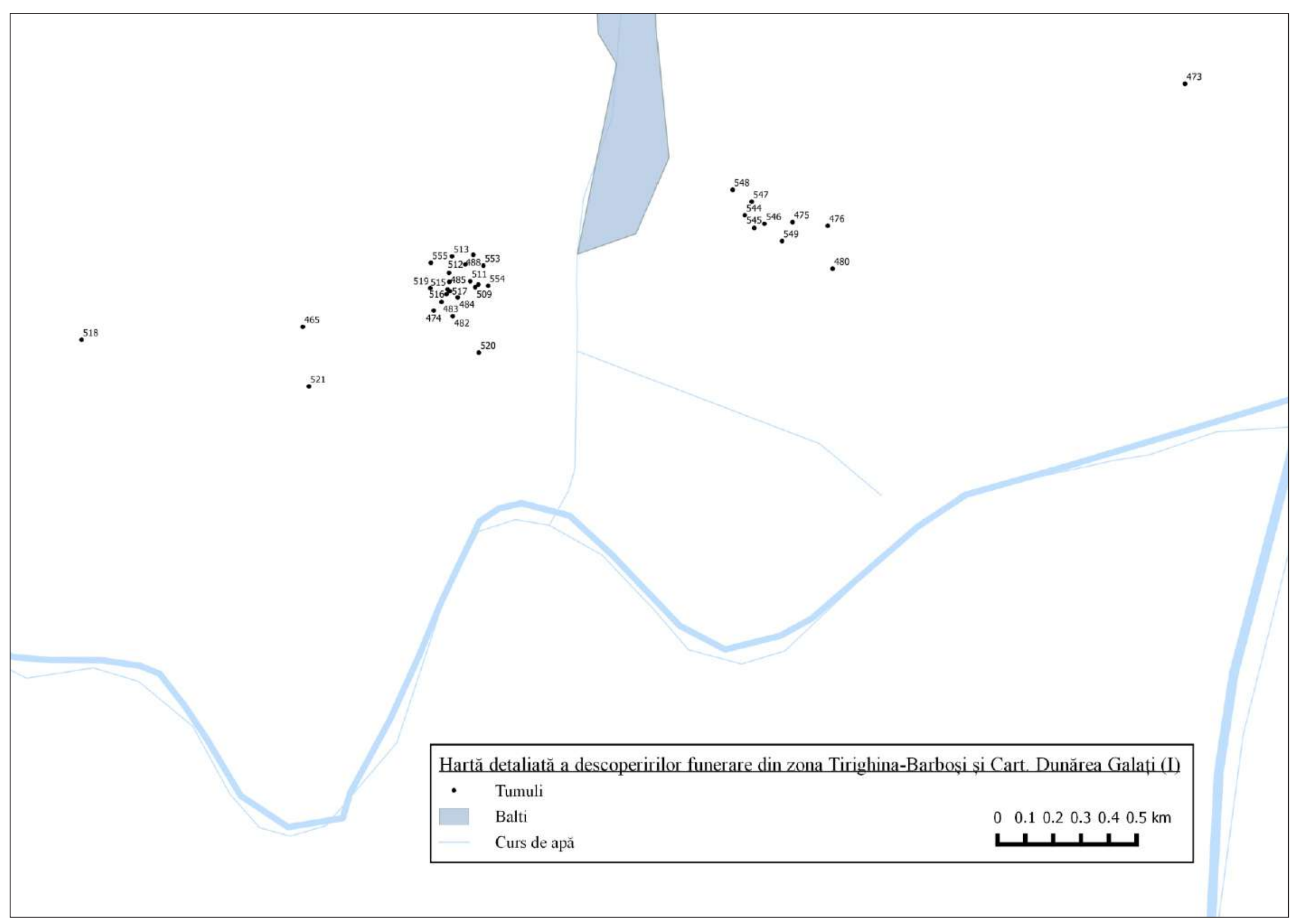

PI. XI 


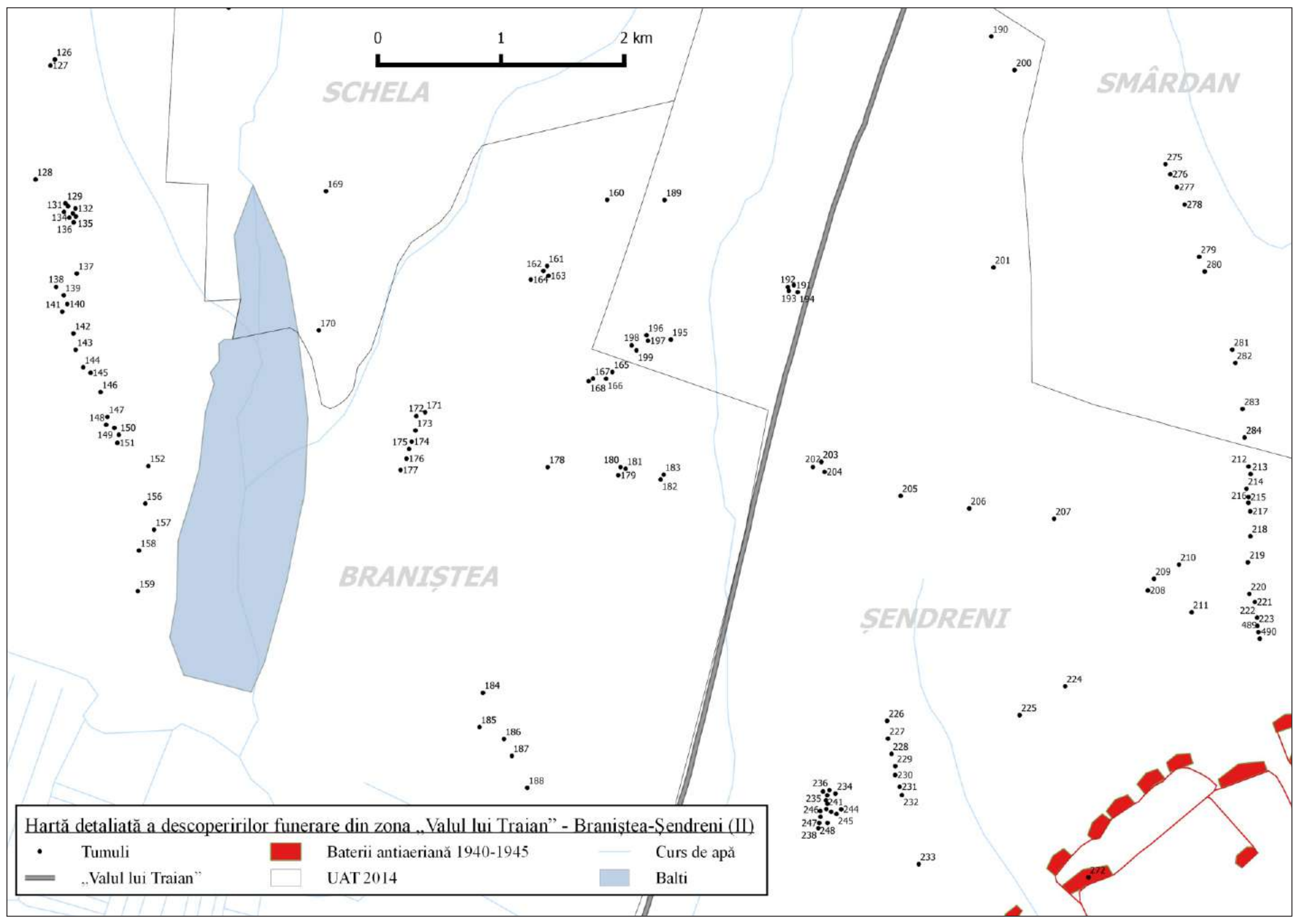

PI. XII 


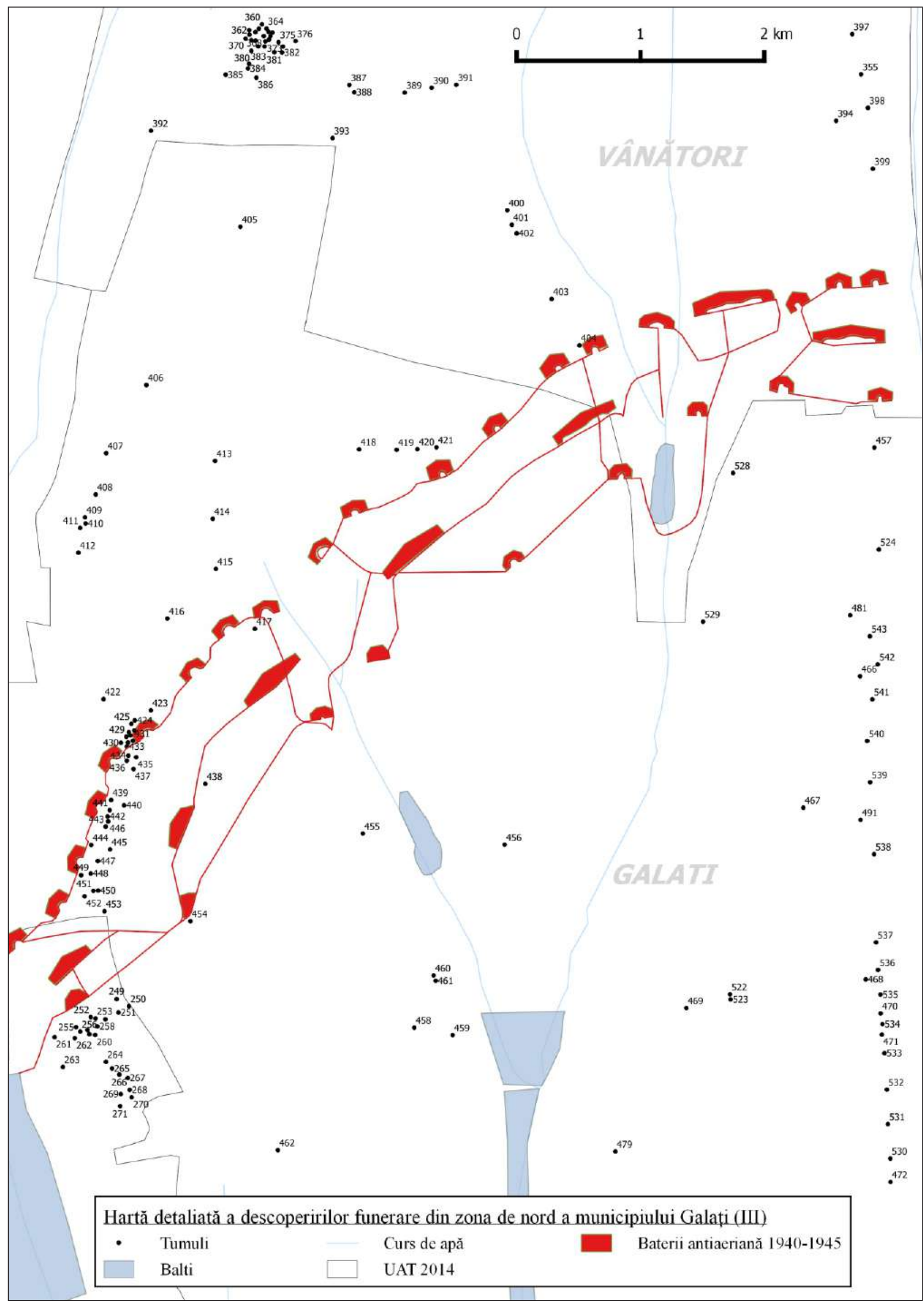




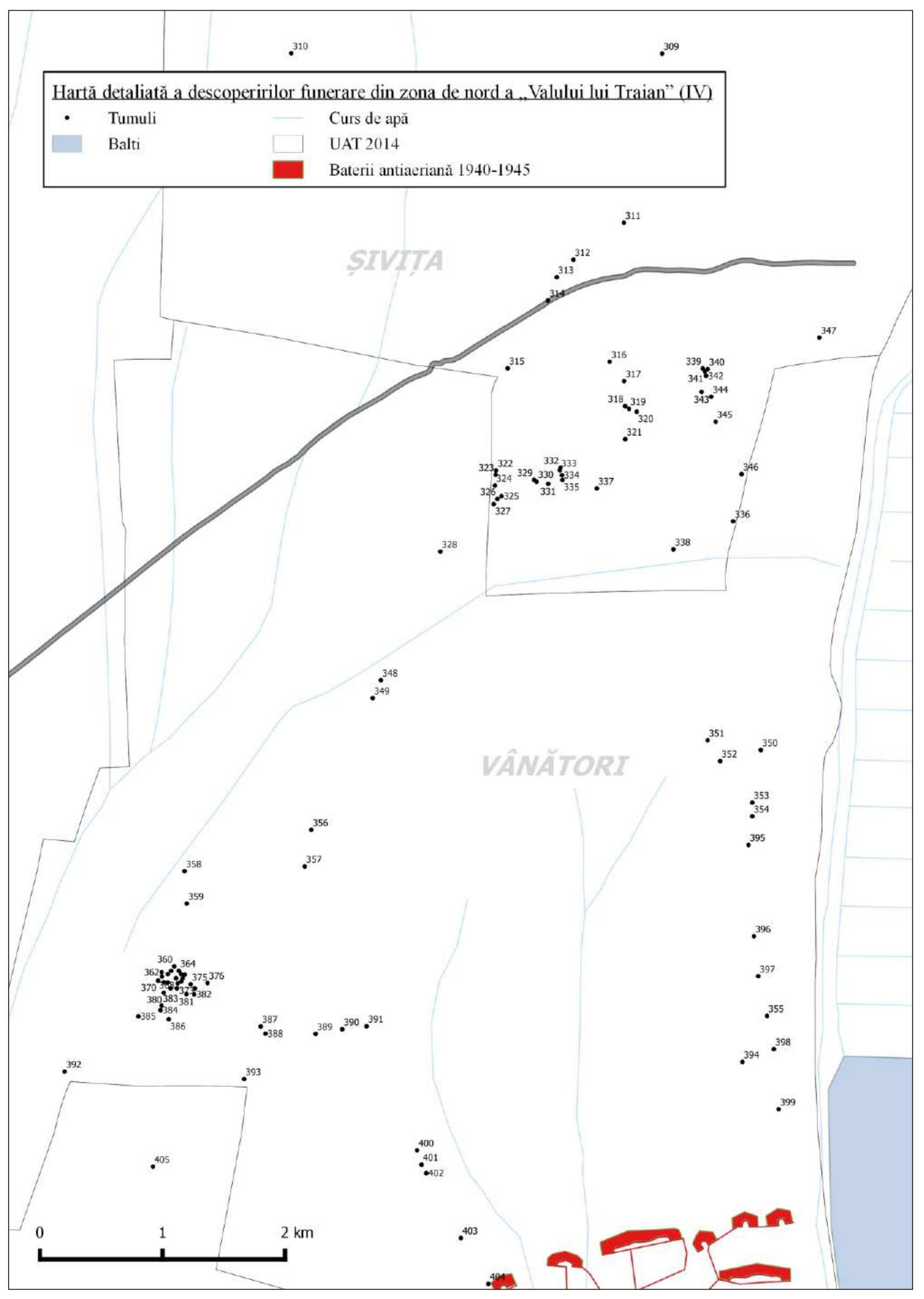

Pl. XIV 


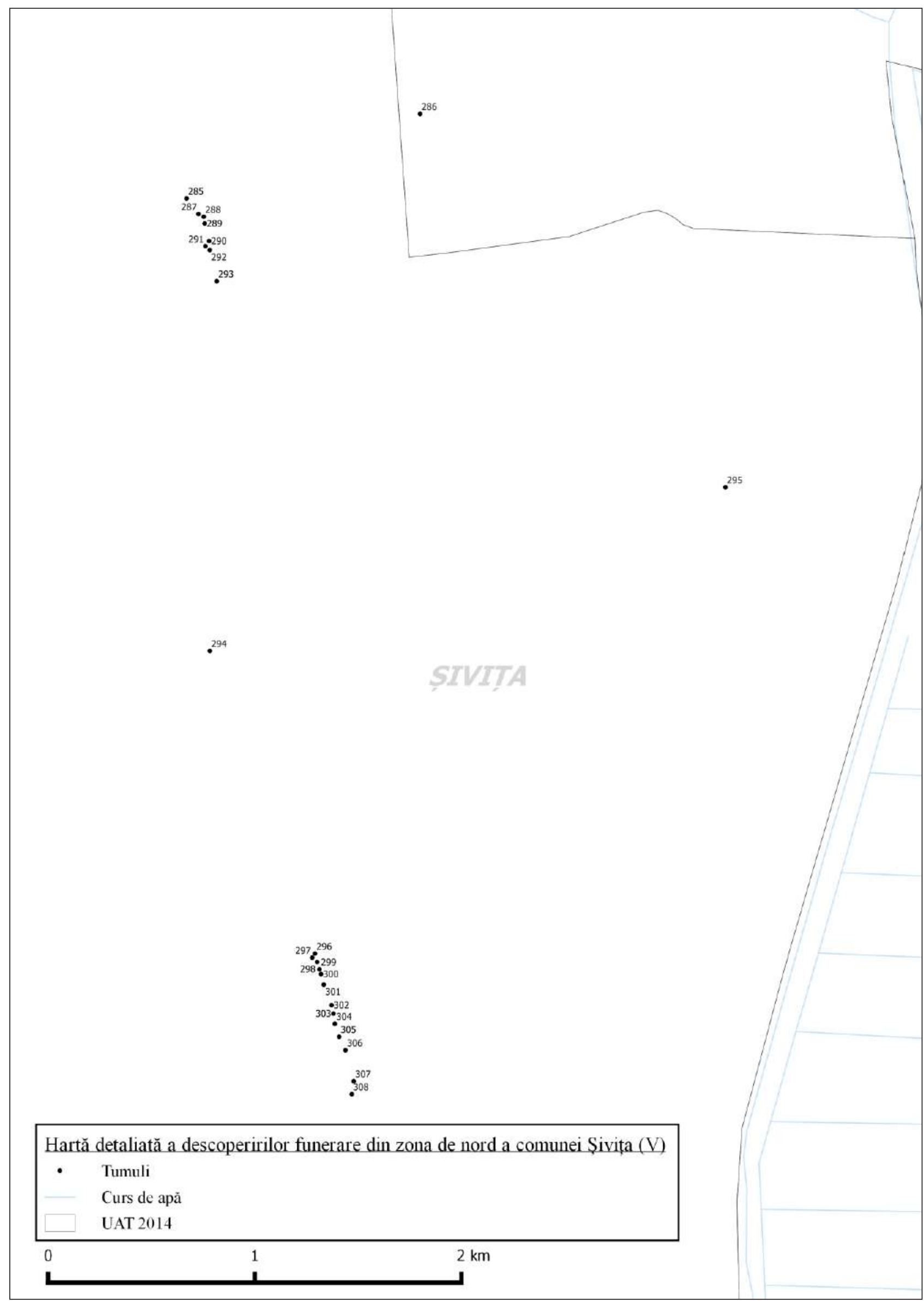

PI. XV 

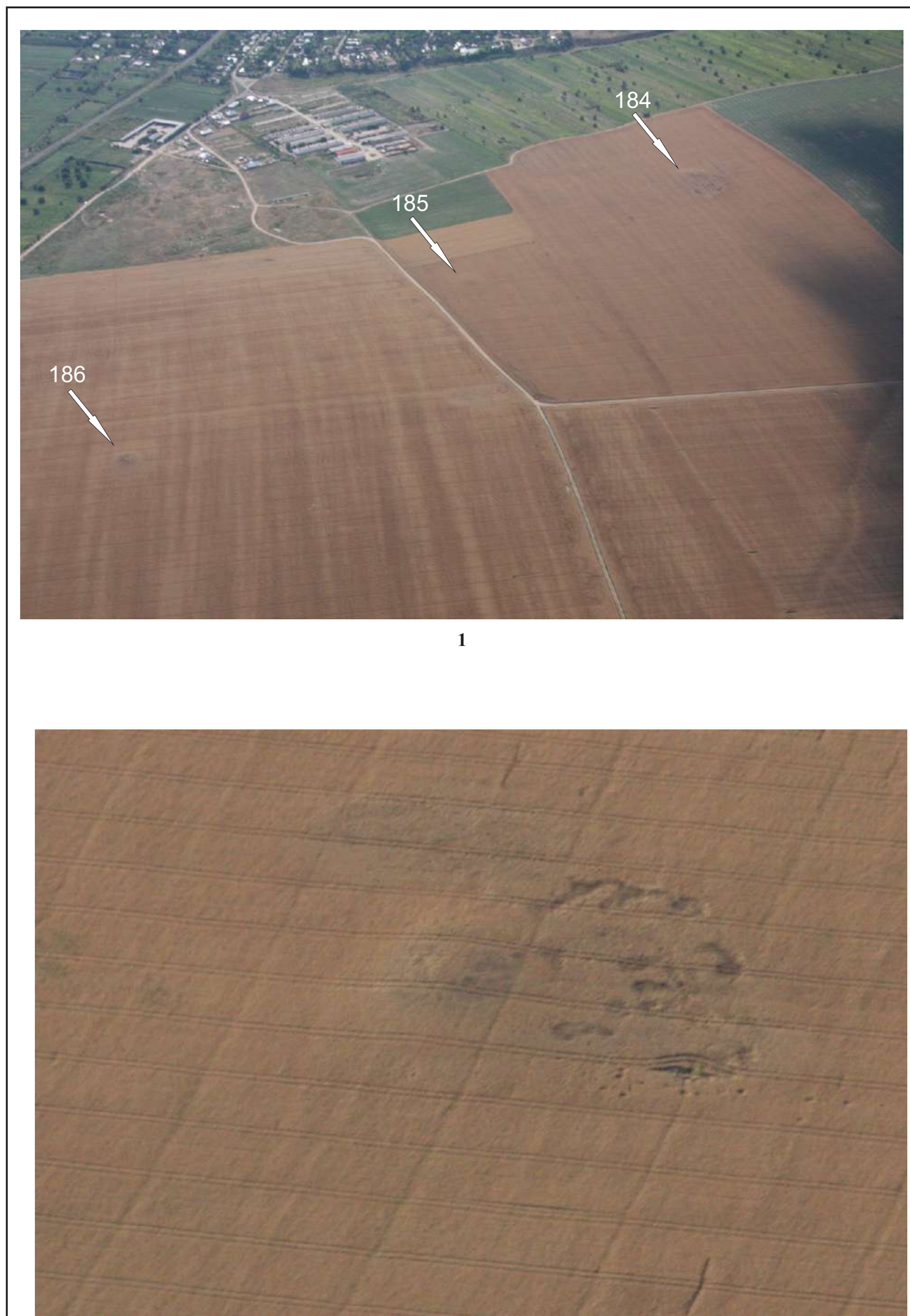


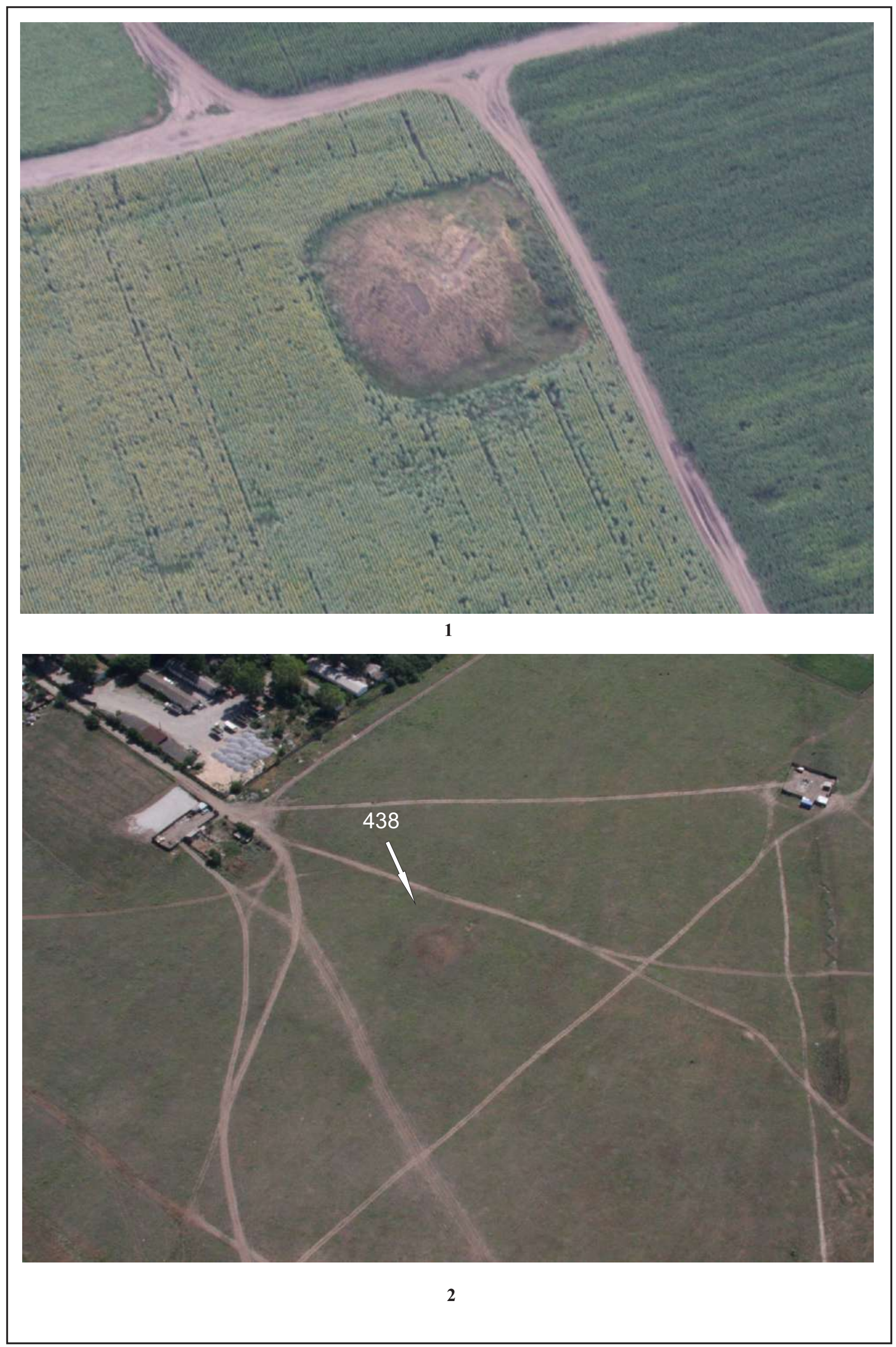

PI. XVII 


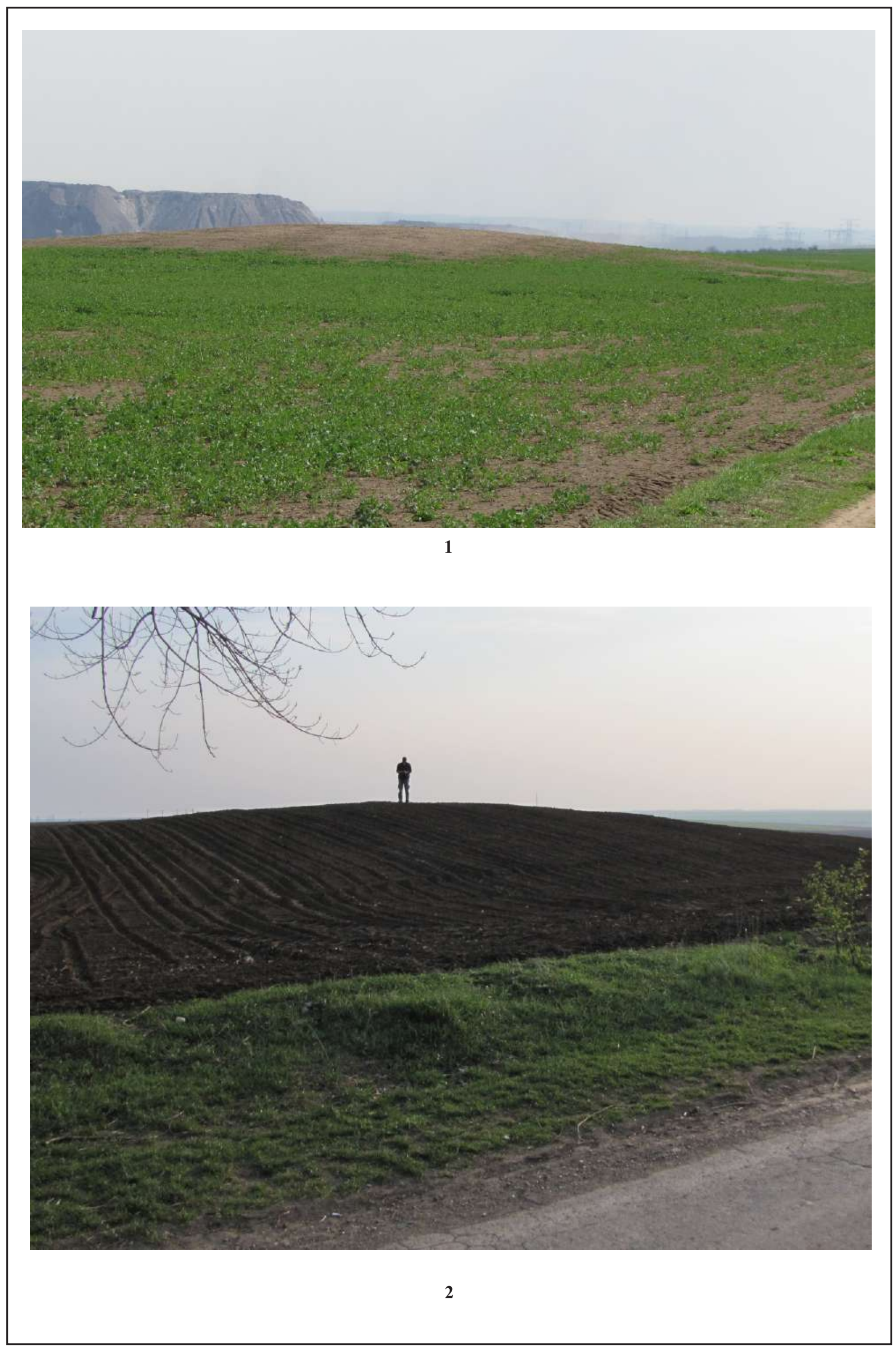

PI. XVIII 


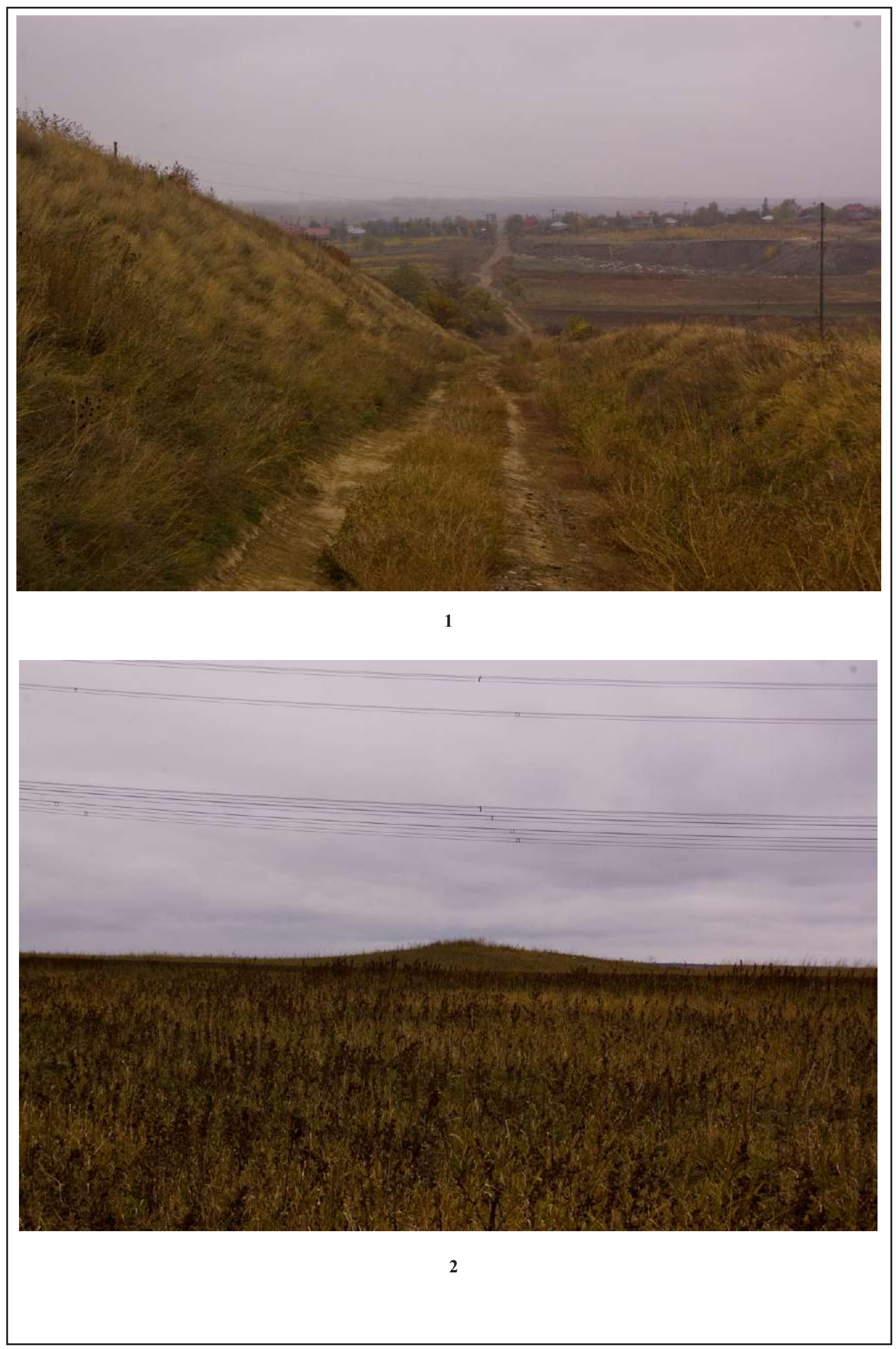

PI. XIX 


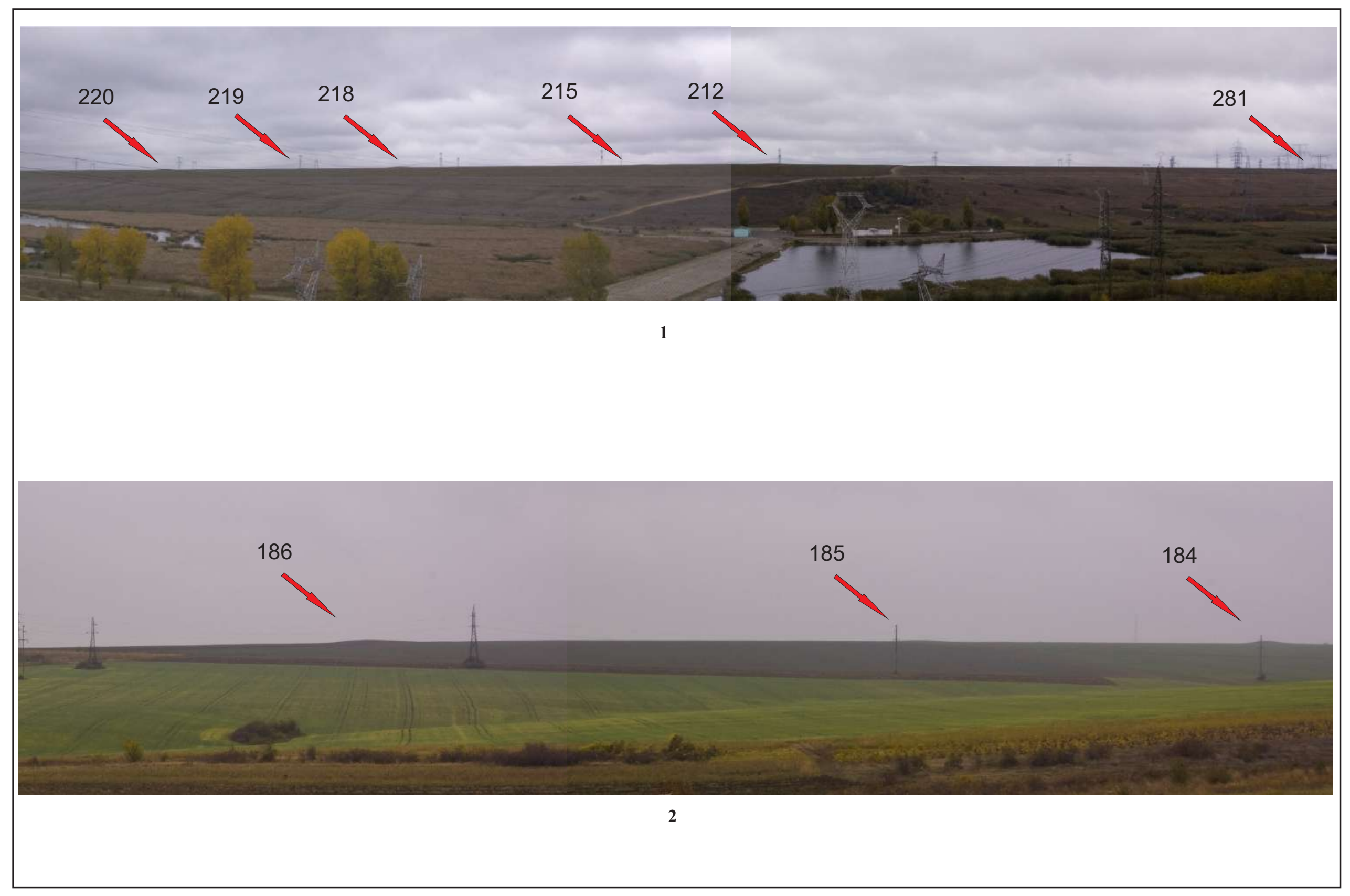

PI. XX 


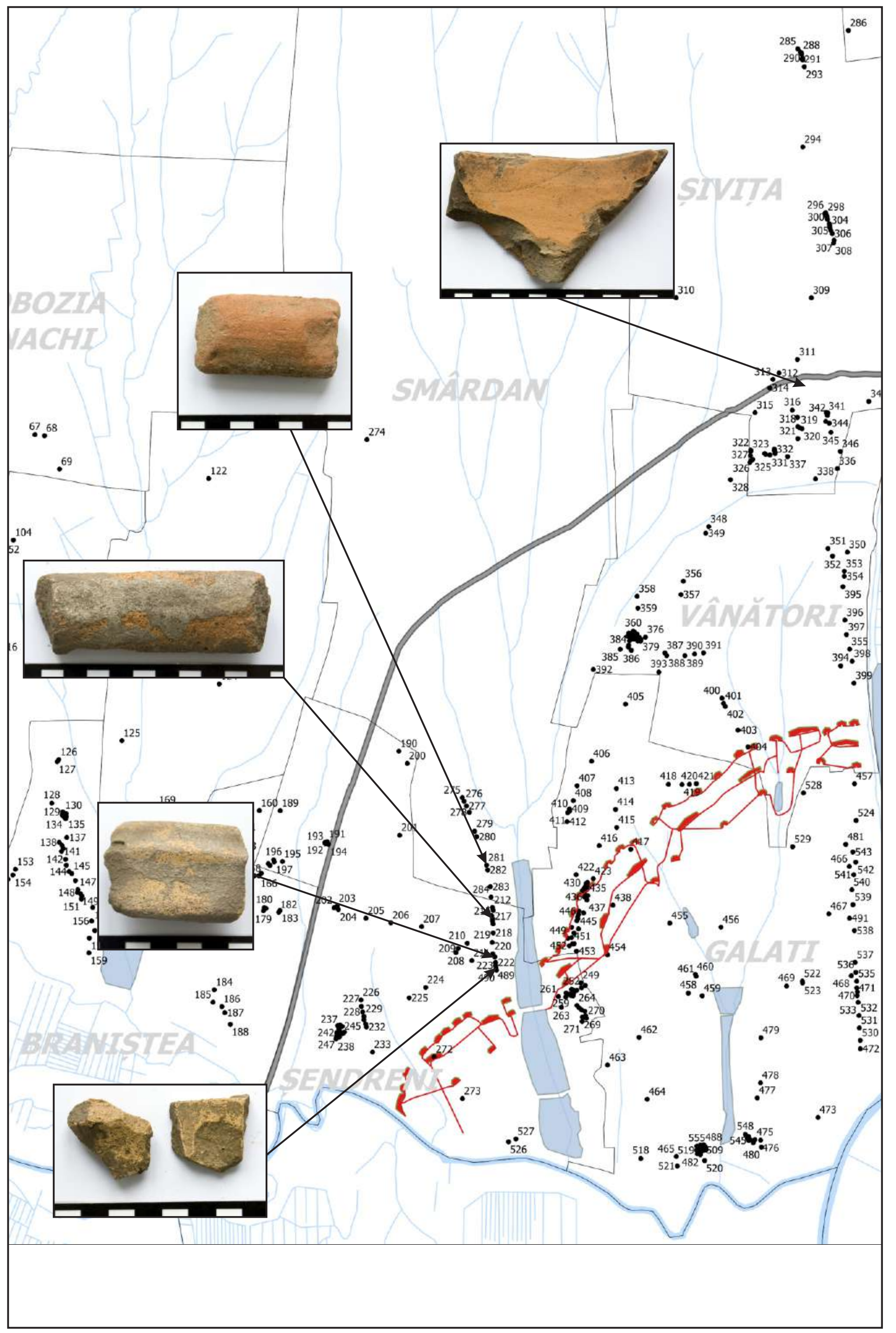




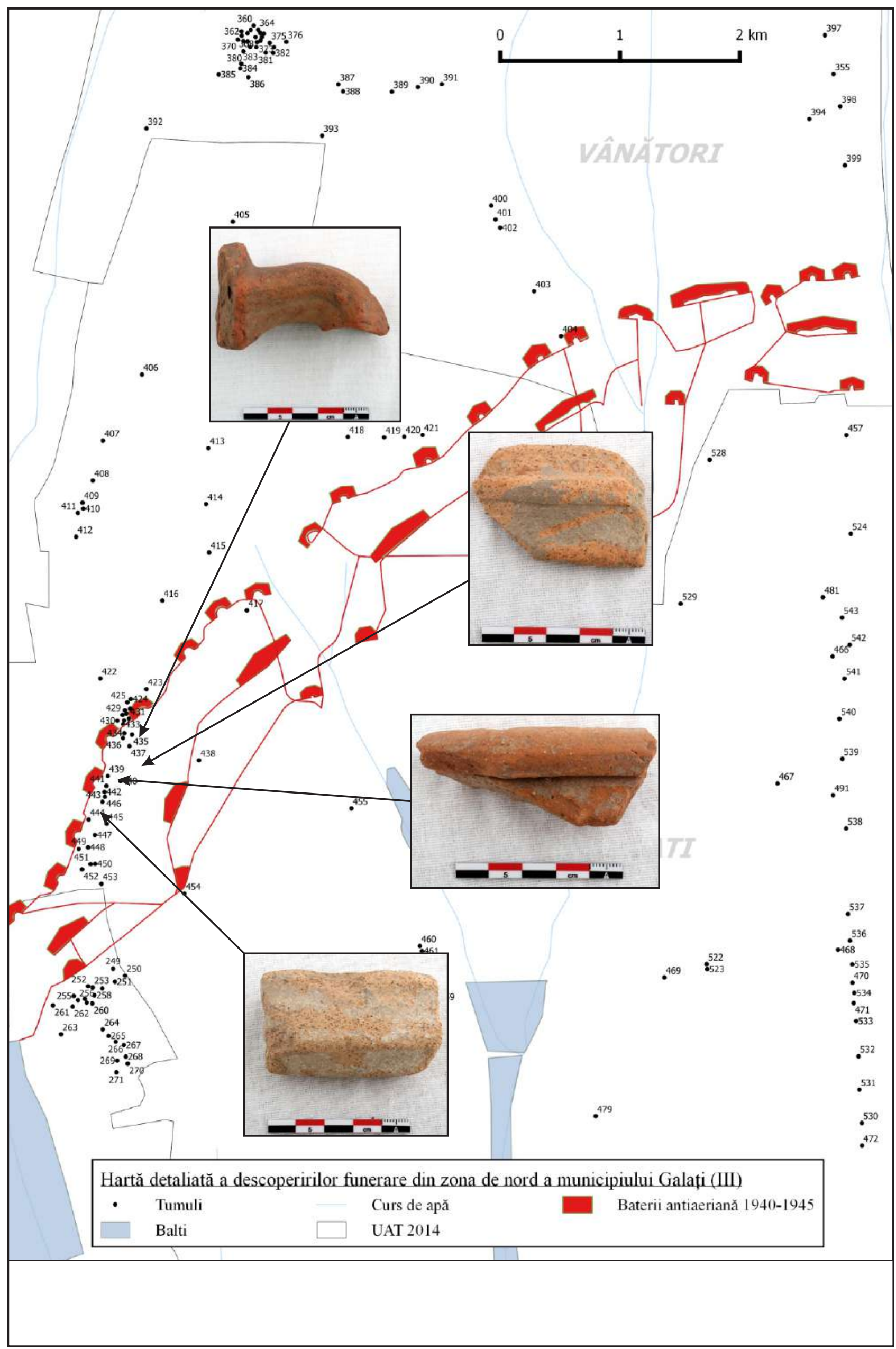

